Universidad Nacional de La Plata

Facultad de Humanidades y Ciencias de la Educación

Secretaría de Posgrado

Tesis para optar por el grado de Doctora en Historia

“200 años es una sola vez”.

Los discursos y las prácticas conmemorativas de los gobiernos de Argentina, Ecuador, Bolivia y Venezuela durante sus bicentenarios de "independencia" (2009-2011)

Autora: María Laura Amorebieta y Vera

Director: Dr. Andrés Bisso

Co-director: Mg. Mauricio Chama 


\section{Resumen}

Hacia el año 2009 varios países de América del Sur se dispusieron a conmemorar los doscientos años del inicio de los procesos de independencia del régimen colonial español. Impulsados por la excepcionalidad de esta efeméride, los Estados destinaron significativos recursos económicos y humanos para poner en marcha un vasto repertorio de actividades festivas y conmemorativas. A su vez, aquella misma razón -al calor de las disputas políticas del momento- fue la que inspiró en el campo intelectual y académico intensos debates y controversias sobre el pasado, el presente y el futuro de las naciones y la región en su conjunto.

La presente investigación procura volver sobre algunos de estos acontecimientos con el fin de precisar cuáles fueron los usos que hicieron del pasado, de qué manera reconstruyeron la memoria histórica y cómo restauraron, a partir de esas operaciones, ciertas identidades colectivas los gobiernos de Argentina, Bolivia, Ecuador y Venezuela durante sus celebraciones de los bicentenarios de "independencia".

Para ello, se examinan las prácticas y los discursos conmemorativos oficiales con la certeza de que los mismos constituyen un novedoso punto de entrada para indagar en los mecanismos simbólicos a partir de los cuales estos gobiernos -enmarcados en el llamado "giro a la izquierda" - intentaron reconstruir las identidades y los imaginarios sobre la nación, a la vez que para ahondar en los sentidos políticos y estratégicos que rodearon a las celebraciones en cuestión.

Más que aspirar a develar la "naturaleza" de aquellos fenómenos políticos o, siquiera, la carga de verdad de dichos acontecimientos, se buscará analizar qué visión del mundo revelaron esos anhelos y, en última instancia, contribuir a la comprensión de las mencionadas experiencias gubernamentales a partir de esos momentos particulares dentro de sus trayectorias.

Palabras clave: Bicentenarios - Usos del pasado - "Giro a la izquierda" Conmemoraciones 


\section{Índice}

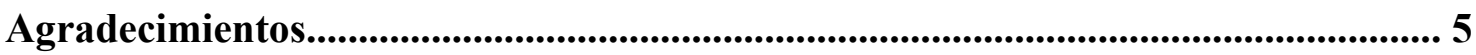

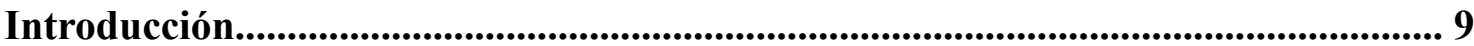

I. Presentación general..........................................................

II. Historia, memoria, conmemoraciones. Algunas

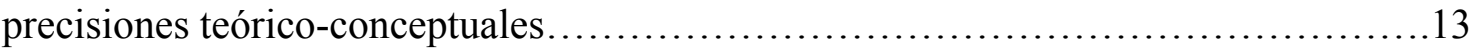

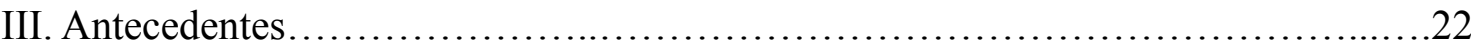

IV. El enfoque y la estructura de esta tesis...................................... 31

Capítulo I: Política, fiesta y nación bajo un nuevo centenario......................................35

I. América del Sur en el cambio de siglo. Breves apuntes sobre los orígenes

del llamado "giro a la izquierda" en Venezuela, Argentina, Bolivia y Ecuador...........35

II. Los regímenes conmemorativos del bicentenario. Orígenes,

fundamentos y primeras aproximaciones........................................ 43

III. Los eventos oficiales del bicentenario. Programas, escenarios

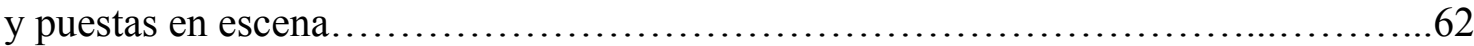

Capítulo II: Los usos del pasado.

Historias e identidades nacionales puestas a consideración.....................................74

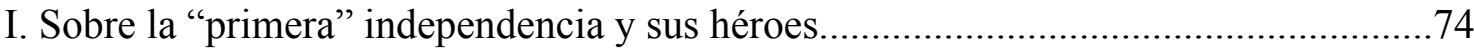

II. De la "primera" a la "segunda" independencia. Las otras gestas precursoras...........98

III. Latinoamericanismo y antiimperialismo en la narrativa bicentenaria..................115 


\section{Capítulo III: Los repertorios festivos del bicentenario.}

Formas, propósitos y significados.

I. Las liturgias políticas de los bicentenarios

II. Las aristas "populares" de los festejos bicentenarios 149

III. Fiesta y política en los aniversarios patrios. Segundas consideraciones provisorias

Capítulo IV: Bicentenarios en disputa. Los debates y las controversias en torno a la "correcta" narración del pasado nacional.........................................174

I. “Un Bicentenario del MAS”. Las polémicas en Bolivia............................................175

II. “La voz 'guayaquileña' de quienes no mienten”. Las polémicas en Ecuador...........185

III. “Oda a los ganados y a las mieses”. Las polémicas en Argentina...........................194

IV. "Ni dinastías coronadas o uniformadas". Las polémicas en Venezuela..................207

V. "El Bicentenario se enciende". Terceras consideraciones provisorias....................217

Capítulo V: Estado, política y nación en tiempos de bicentenarios.........................220

I. ¿"Bolivia es una sola montaña"?

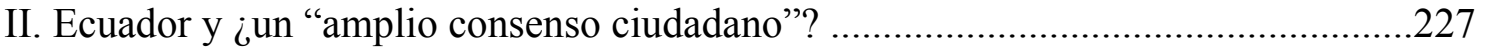

III. ¿Nos abrazamos y nos enfrentamos? Argentina entre la crisis y el festejo.............232

IV. Venezuela, ¿hacia "la consolidación plena de la patria nueva"? ............................238

V. Fiesta, representación colectiva y disputa hegemónica. Cuartas consideraciones provisorias 
Bibliografía. 


\section{Agradecimientos}

Ésta es una tesis que, como tantas otras, llegó a su fin gracias al impulso, la guía y el abrigo de muchas personas.

En primer lugar, quiero darle las gracias a Andrés Bisso, mi director. Cuando recién me había recibido de socióloga y comenzaba a tientas a dar clases de Historia Social General, me di cuenta que lo que más me apasionaba era la historia latinoamericana. Para dar cauce a ese interés, una amiga sugirió que me presentara a "becas", tarea que implicaba esbozar un proyecto de investigación pero, ante todo, encontrar un director.

Fue así que le escribí un correo electrónico - con una serie de ideas vagas y absurdas- a quien había sido mi profesor de Historia Social Latinoamericana en la Facultad, allá por el 2009. Andrés no solo me respondió rápidamente y me orientó en la delimitación de un problema de investigación y en el armado de un plan de trabajo; sino que también me abrió las puertas de la cátedra y empezó a enseñarme -a su tan particular y heterodoxo modo- a observar, investigar y pensar la historia. Algo que, por fortuna, sigue haciendo hasta el día de hoy.

Creo que todos los que tenemos la suerte de trabajar junto a Andrés coincidiríamos en afirmar que, además de generoso y humilde, se trata de un compañero y un maestro riguroso, ingenioso y, sobre todo, bizarramente divertido. Esas cualidades no solo enriquecieron mi trabajo, sino que hicieron de éste un camino mucho más feliz.

De igual modo, quisiera agradecer y reconocer a mi otro director, Mauricio Chama. Por "adoptarme" como becaria en las urgencias e imprevistos que suelen surgir en las vísperas de las convocatorias a las becas doctorales; por orientarme y ayudar a organizarme, especialmente, en los inicios de este recorrido cuando ignoraba cuáles eran los pasos a seguir; y por alentarme y siempre hacerse el lugar de -como solemos 
decir en este mundo- leerme, incluso cuando sus tareas y preocupaciones eran más importantes y apremiantes.

Esta investigación tampoco hubiera sido posible sin las becas de formación que otorga el CONICET. Asimismo, quiero agradecer a la Facultad de Humanidades y Ciencias de la Educación de la UNLP, en donde me formo desde el 2007 y donde tengo el orgullo de dar clases. En este sentido, deseo destacar y reconocer también las políticas públicas que, durante aquellos años, posibilitaron la ampliación y el fortalecimiento del sistema científico y universitario argentino.

Otro espacio fundamental en este trayecto ha sido el Doctorado en Historia de la Facultad. Agradezco, entonces, a los directores que estuvieron a su cargo mientras fui alumna del mismo, Fernando Barba y Patricia Flier; a los profesores con quienes cursé varios seminarios; y, especialmente, a sus secretarios -Marcelo Starcembaum, Facundo Lafit y Andrea Raina- por su inagotable paciencia.

Por otra parte, le quiero agradecer a mis compañeros del Centro de Investigaciones Socio-Históricas del IdHICS, del Doctorado y a aquellos con los que comparto el proyecto de investigación titulado "La Historia Reciente y los usos públicos del pasado: militancias, etnicidad y políticas de la memoria desde/en América Latina", que amablemente leyeron y comentaron algunos pasajes de esta tesis.

En particular, a Emmanuel Kahan, por su generosidad a la hora de sumarme a distintos grupos de trabajo; a Santiago Cueto Rúa, por sus observaciones agudas; a Pablo Moro, por su amistad, su alegría y su confianza en mi; y a mi amiga Belén Morris, que me empujó a iniciar este camino.

Me gustaría reconocer, igualmente, a mis otros dos compañeros de cátedra, Leandro Sessa y Leandro García, que me recibieron afectuosamente en sus respectivos espacios, confiaron en mí y me dieron margen para que hiciera y aprendiera junto a ellos. Siempre digo que tengo una suerte enorme de haber llegado a esa cátedra y creo que, de una u otra manera, los consejos, las discusiones y las tareas compartidas nutrieron este trabajo. 
Por otro lado, extiendo mi agradecimiento a Fernando Degiovanni, por los diálogos cálidos y estimulantes, así como por su hospitalidad y generosidad durante aquellos meses fríos de principios de 2018. Y a Sinclair Thomson, por sus consejos y su gentil predisposición a responder a todas mis consultas.

El grupo de investigación titulado "Vitrinas nacionales y estrategias estatales de comunicación en las conmemoraciones de los centenarios y bicentenarios de las independencias en América del sur" ha sido otro espacio de intercambio fructífero del cual este trabajo se vio beneficiado. Por ello, agradezco, a su vez, a mis compañeros y a su director argentino, Pablo Ortemberg, que me invitó a participar de jornadas, charlas y workshops.

Antes de obtener la beca, me desempeñé durante cuatro años como empleada en el Ministerio de Economía junto a varias personas con quienes compartí y aprendí cosas muy valiosas del trabajo y de la vida. Sebastián Mateo, Bernardo Galinelli y, en especial, mis queridos amigos, Vanina Saade Minio y Ezequiel Borromeo se encargaron de ayudarme, respaldarme y alentarme cuando decidí hacer esta apuesta.

A medida que me internaba en la escritura de la tesis, un grupo de amigos se volvió indispensable para mí. Con Lorena Vergani y Manuela Belinche no solo compartí incontables cursadas y jornadas de estudio desde mis primeros días como estudiante de Sociología, sino también el desafío de empezar a dar clases en la universidad. Pero, sobre todo, comparto con ellas desde hace más de doce años un profundo e inconmovible lazo de hermandad.

Macarena Ferrando, Juliana Lira, Rocío López Aranguren, Francisco Etcheverry, Nicolás Soncini y Federico Colombo completan ese círculo. Con ellos crecí y espero seguir haciéndolo. Su persistente complicidad, frescura, cariño y compañía fueron esenciales para emprender muchas travesías -incluida ésta- sin perderme ni desanimarme. 
De igual forma, considero que estas páginas deben mucho a mi papá. Por los intereses afines, por sus esfuerzos, por su generosidad y, a pesar de las dificultades, por su presencia sostenida a lo largo de estos años. También a Mariana Calahorra. Ella es sin dudas una de las personas más fundamentales de mi vida. Me acompaña, me cuida y me guía incondicionalmente desde hace casi tres décadas. Y me resulta imposible imaginarme hoy, acá, escribiendo estas líneas, sin su llegada -tan imprevista como redentora- a la casa de mi infancia.

Finalmente, quisiera agradecer a Javier Guiamet, a quien conocí - gracias al azar y a nuestro director- cuando todo esto recién empezaba. Además de ser un colega que admiro mucho y que influyó decisivamente en este trabajo, Javi se convirtió en mi amor y mi mejor amigo. Me abrió las puertas de su vida, su familia y su casa, haciendo que los días junto a él y Néstor -nuestro malcriado e increíble border collie- hayan sido y sigan siendo los más felices de mi vida... Por todo eso, y por todo el amor que vendrá, a él quiero dedicar esta tesis.

Villa Castells, 8 de julio de 2019. 


\section{Introducción}

\section{Presentación general}

Hacia el año 2009 varios países de América del Sur se lanzaron a conmemorar los doscientos años del inicio de los procesos de independencia del régimen colonial español. Impulsados por la excepcionalidad de esta efeméride, los Estados destinaron significativos recursos económicos y humanos para poner en marcha un repertorio de actividades que incluyeron celebraciones públicas, exhibiciones, desfiles cívicomilitares, monumentos, museos y publicaciones, dando origen a diversos eventos festivos, políticos y culturales. A su vez, aquella misma razón -al calor de las disputas políticas del momento- fue la que inspiró en el campo intelectual y académico intensos debates y controversias sobre el pasado, el presente y el futuro de las naciones y la región en su conjunto.

La presente investigación procura volver sobre algunos de estos acontecimientos con el fin de precisar cuáles fueron los usos que hicieron del pasado, de qué manera reconstruyeron la memoria histórica y cómo restauraron, a partir de esas operaciones, ciertas identidades colectivas los gobiernos de Argentina, Bolivia, Ecuador y Venezuela durante sus celebraciones bicentenarias, para lo cual se observarán las prácticas y los discursos conmemorativos allí desplegados. ${ }^{1}$

Puntualmente, se analizarán: para el caso de Argentina, las celebraciones del 25 de mayo de 2010, es decir, el bicentenario de la Revolución de Mayo; en cuanto a Bolivia,

\footnotetext{
1 Siguiendo a Roger Chartier (1996) y a contramano del llamado giro lingüístico, los discursos y las prácticas, es decir, la construcción discursiva del mundo social y la construcción social de los discursos, constituyen dos esferas que, aunque relacionadas, pueden diferenciarse. En este sentido, entiendo a las producciones discursivas en tanto construcciones capaces de modelar la realidad social, al tiempo que las inscribo en las fuerzas y determinaciones objetivas, en los comportamientos y gestos que, a la vez, limitaron e volvieron posible su enunciación.
} 
se revisarán dos festejos patrios: el bicentenario de la Revolución de Chuquisaca que tuvo lugar el 25 de mayo de 2009 en El Villar y el bicentenario de la Primera Junta Tuitiva de Gobierno acontecido el 16 de julio de 2009 en La Paz; para el caso de Ecuador, se observarán los festejos del 10 de agosto de 2009 a partir de los cuales se conmemoró el bicentenario de la Primera Junta de Gobierno de Quito; y, finalmente, respecto a Venezuela, se examinarán las celebraciones del 19 de abril de 2010 bicentenario de la Revolución del 19 de abril-, así como la del 5 de julio de 2011 bicentenario de la firma del Acta de la Declaración de Independencia--

De modo que las páginas que siguen estarán orientadas a indagar en los mecanismos simbólicos a partir de los cuales estos gobiernos intentaron reconstruir las identidades colectivas y los imaginarios sobre la nación, a la vez que ahondarán en los sentidos políticos y orientaciones estratégicas que rodearon a las celebraciones en cuestión. Más que aspirar a develar la "naturaleza" de aquellos fenómenos políticos o, siquiera, la carga de verdad de dichos acontecimientos, se buscará analizar qué visión del mundo revelaron esos anhelos y, en última instancia, contribuir a la comprensión de un momento particular de esas experiencias políticas.

Llegado a este punto de la presentación, se imponen, sin embargo, dos observaciones preliminares. La primera se vincula con la renovación de los estudios sobre memoria, analizada desde distintas perspectivas como deber, trabajo, abuso o boom de la memoria, momento-memoria o memoria saturada, entre otros (Todorov, 2000; Ricoeur, 1999, 2013; Huyssen, 2002; Nora, 2008; Robin, 2012). Sin entrar en la especificidad de estos debates académicos, me interesa recuperar un aspecto que todas estas discusiones han vuelto a poner de relieve: la dimensión social de la memoria.

Tomando como punto de partida los análisis pioneros de Maurice Halbwachs, Marie-Claire Lavabre (2006) ha insistido en el carácter eminentemente social de la memoria, la cual excede la capacidad personal de recordar en tanto las representaciones del pasado que los individuos llevan consigo se ven atravesadas por diversas memorias, tradiciones y representaciones y se encuentran especialmente en tensión con las elaboraciones institucionales, es decir, con la memoria oficial o histórica.

A diferencia de la memoria colectiva condicionada por la experiencia vivida y/o transmitida del grupo, resulta pertinente destacar, a los fines de este estudio, el modo en 
que la autora concibe a la memoria histórica, entendiéndola como aquella "forma de historia dotada de finalidad, guiada por un 'interés' que no es el del conocimiento sino el del ejemplo, el de la legitimidad, el de la polémica, el de la conmemoración, el de la identidad" (2006: 44). Así, la memoria histórica es asimilada a los usos del pasado, los cuales -orientados a disputar y/o homogeneizar representaciones sobre aquél- pueden devenir un reflejo de las memorias colectivas disponibles o en gestación, así como prescripciones con fecha de vencimiento.

Detenernos en los contextos concretos desde los cuales se desplegaron esas operaciones de memoria constituye otra tarea esencial en tanto los procesos de recuerdo y olvido no pueden aislarse de las estructuras económicas, sociales, políticas y culturales que enmarcan la acción de los sujetos. Reconocer la importancia del contexto en la (re)construcción de las representaciones sobre el pasado supone concebir a la memoria como un recurso que pese a referirse al pasado, se ejecuta y se actualiza permanentemente desde la contemporaneidad.

La coyuntura adquiere, entonces, un papel crucial a la hora de definir -y analizarlas formas y los contenidos de toda memoria histórica. De esta manera, resulta ineludible adelantar algunos rasgos distintivos de la escena sudamericana al momento de las conmemoraciones de los bicentenarios, lo cual posibilitará, a su vez, esclarecer los criterios detrás de la elección de casos. Si bien existen importantes diferencias en torno a las trayectorias, composición organizativa, capacidades estatales, agendas programáticas y estrategias de cambio político de los entonces gobiernos de Argentina, Bolivia, Ecuador y Venezuela, esta selección se fundamenta en la identificación de una matriz político-económica común de corte posneoliberal.

Numerosos autores que han abordado esta temática coincidieron en sostener que a principios del 2000, este conjunto de países habría experimentado un "giro a la izquierda", aludiendo con ello no sólo a la puesta en marcha de políticas tendientes a reducir las diferencias sociales, sino también orientadas a la producción de nuevos imaginarios políticos e ideológicos que propiciaron una revalorización de lo nacional y lo popular en términos emancipatorios (Ellner, 2004; Garretón, 2006; Ramírez, 2006; 
Vilas, 2006; Arditi, 2008; Sader, 2008; French, 2009; Panizza, 2009; Cameron y

Hershberg, 2010; Ceceña, 2011). ${ }^{2}$

En estos cuatro casos, los movimientos, coaliciones o partidos políticos que conquistaron los espacios de poder, lo hicieron luego del estallido de profundas crisis económicas, sociales, políticas e institucionales (Venezuela, 1998; Ecuador, 1999; Argentina, 2001; Bolivia; 2003), las cuales legitimaron un terreno propicio para la puesta en marcha de distintos proyectos "refundacionales" que se propusieron, entre otras cosas, una revisión del pasado nacional, de los marcos y puntos de referencias de las memorias oficiales (Pollak, 2006). ${ }^{3}$

De esta forma, los bicentenarios de "independencia" habrían devenido ocasiones favorables para que los gobiernos de los mencionados países organizaran y desplegaran importantes eventos festivos y conmemorativos dirigidos a disputar y reactualizar las representaciones sobre la identidad nacional, así como desplegar sus concepciones de Estado, nación y sociedad.

\footnotetext{
2 Más allá de la diversidad de planteamientos, matices y enfoques teóricos presentes en cada uno de esos trabajos, todos estos autores tienen en común haberse distanciado de aquellas perspectivas dicotómicas que plantearon la necesidad de distinguir entre una izquierda "buena" y otra "mala" (Castañeda, 2006) o izquierdas "socialdemócratas" frente a izquierdas "populistas o radicales" (Lanzaro, 2007; Alcántara, 2008) para acordar, en cambio, que -no obstante las diferencias que atravesaron a los procesos políticos en cuestión, cuyo análisis, además, resulta esencial para lograr asir la complejidad de la escena latinoamericana de aquel entonces- todas esas experiencias de gobierno habrían confluido en un horizonte común susceptible de ser caracterizado, al menos en términos generales, como de izquierda.
}

3 Es preciso advertir que, dentro del conjunto de naciones que formaron parte del denominado "Grupo Bicentenario"-es decir, el organismo multilateral creado con el fin de articular a escala regional los festejos de los 200 años del inicio de los procesos de independencia de la América española-, se seleccionaron como casos de estudio aquellos países miembros sudamericanos que se encontraban, en aquel entonces, bajo gobiernos caracterizados como "posneoliberales" o "de izquierda". Si bien Paraguay podría haber sido incluido en este recorte -en tanto formalizó su ingreso a la mencionada entidad bajo la presidencia de Fernando Lugo Méndez en el 2009-, fue el carácter breve e interrumpido de esta experiencia de gobierno lo que condujo a su exclusión en la medida que impedía pensar el análisis de la celebración del bicentenario de la independencia paraguaya en relación a un proyecto hegemónico de mayor alcance en el tiempo. Es que el estudio de las prácticas y los discursos conmemorativos desplegados en Bolivia, Ecuador, Venezuela y Argentina en ocasión de los bicentenarios pretende, en última instancia, reflexionar sobre fuerzas políticas enmarcadas en el llamado "giro a la izquierda" que experimentaron varias reelecciones presidenciales, consiguiendo alargar su permanencia en el poder y, de esa manera, avanzar no solo en la consecución de sus agendas políticas, sino especialmente en una mayor definición de sus improntas, concepciones y búsquedas político-ideológicas.

En este sentido, conviene recordar las palabras de Lucien Febvre, para quien "toda historia es elección. Lo es porque existe el azar que aquí destruyó y allá salvaguardó los vestigios del pasado. Lo es porque existe el hombre: cuando los documentos abundan, abrevia, simplifica, hace hincapié en esto, relega aquello a segundo término. Y lo es, principalmente, por el hecho de que el historiador crea sus materiales o los recrea, si se quiere: el historiador no va rondando al azar a través del pasado, como un trapero en busca de despojos, sino que parte con un proyecto preciso en la mente, un problema que resolver, una hipótesis de trabajo que verificar" (2017 [1952]: 21). 
Por lo tanto, este trabajo se propone estudiar de qué manera los Poderes Ejecutivos de Argentina, Bolivia, Ecuador y Venezuela se han vinculado con el pasado para resignificarlo. Dar cuenta de los modos en que éste fue restaurado y de las controversias y ambigüedades que emergieron en torno a esta acción en ocasión de los bicentenarios de "independencia" habilita un novedoso punto de entrada para reflexionar sobre los proyectos políticos e ideas de nación desplegados en aquel entonces por el kirchnerismo en Argentina, la Revolución democrática y cultural (RDC) en Bolivia, la Revolución Ciudadana (RC) en Ecuador y la Revolución Bolivariana (RB) en Venezuela.

Frente al profuso acervo de investigaciones abocadas al análisis de las aristas socioeconómicas y agendas políticas de las mencionadas experiencias gubernamentales, lo que se buscará aquí es observar cómo lo discursivo, lo simbólico, lo artístico y lo ritual asistieron, durante el período de los bicentenarios, a complejos, contingentes y contradictorios procesos de construcción política, restauración de las memorias históricas nacionales y reactualización de las identidades colectivas.

En este sentido, sostengo que aproximarnos a la historia reciente de los cuatro casos a partir del análisis de sus conmemoraciones bicentenarias supondría una original contribución no solo a los estudios sobre el llamado "giro a la izquierda" en Sudamérica, sino también al campo historiográfico forjado en torno a las celebraciones patrias y a temáticas como los usos del pasado y las tentativas estatales de acción sobre las memorias colectivas.

II. Historia, memoria, conmemoraciones. Algunas precisiones teóricoconceptuales

En el prefacio de Western Historical Thinking: an intercultural debate, Jörn Rüsen plantea: 
desde que se declaró el fin de la 'historia', los 'problemas históricos' parecen haber retornado con aun mayor intensidad que antes. Esta paradoja demanda una nueva orientación o, por lo menos, una nueva reflexión teórica (...) Lo que se necesita es un campo de estudio interdisciplinario e intercultural (2002: 7. Traducción mía).

Con ese diagnóstico, el autor introduce su principal preocupación: cómo pensar a la memoria histórica en tanto campo fundamental de acción y pensamiento humano capaz -junto a la historia académica- de generar sentidos históricos, y cuyo estudio podría contribuir a nuevas formas de entendimiento mutuo. A esta inquietud, que constituye el punto de partida de la presente investigación, es preciso acompañarla de una prevención dirigida a evitar el "uso dogmático de los conceptos donde el estudio específico de campo toma la forma casi de una postal para ilustrar el resultado de una prenoción teórica” (Aboy Carlés, citado en Padilla y Ruiz del Ferrier, 2015: 185).

Las complejas y variables formas de relación entre historia y memoria han sido sobretodo a partir de las últimas décadas del siglo $\mathrm{XX}$ - reelaboradas bajo distintos nudos problemáticos, volviéndose, a su vez, objeto de múltiples debates tanto en el ámbito académico como público (es decir, extradisciplinar). ${ }^{4}$ Ante la heterogeneidad de preguntas y problemas suscitados, esta tesis se detiene y profundiza en el tipo específico de tratamiento de la dimensión temporal que postulan las ceremonias y celebraciones conmemorativas patrias con el propósito último de discutir y volver a reflexionar en torno al modo en que éstas podrían ser entendidas.

A estas alturas, resulta un lugar común señalar que las conmemoraciones procuran impulsar el recuerdo del pasado, elaborando, organizando y actualizándolo en función de las necesidades del presente y las expectativas del futuro de los actores sociales o políticos que las conducen. En este proceso, la historia se convierte así en una herramienta "aleccionadora y legitimadora de la acción en el presente" que posibilita

\footnotetext{
4 Para un análisis de las razones a partir de las cuales la memoria se convirtió en un campo de investigación a nivel global, regional y nacional, y de los debates e inquietudes que se fueron suscitando en ese camino, véase, entre otros, Huyssen (2002), Rossi (2003), Aróstegui (2004), Arias y del Campo (2009), Cattaruzza (2011; 2012) y Bisso et al. (2014).
} 
"resaltar lo esencial de las continuidades sobre lo contingente de las transformaciones temporales" (Bisso y Kahan, 2014: 14). ${ }^{5}$

Es, en este sentido, que aquellas se vinculan con los usos del pasado, los cuales siguiendo los estudios de Alejandro Cattaruzza (2007)-, son concebidos como modos de intervenir en las representaciones y evocaciones de la historia con el objetivo de legitimar posiciones presentes, influir en las contiendas de la hora y, en función de eso, conducir los proyectos futuros; por lo cual podría sostenerse que todo uso del pasado resulta, habitualmente, un uso político de aquél. 6

Por consiguiente, el concepto de representación deviene central en este estudio, razón por la cual se retoman, asimismo, los aportes de la historia cultural. Roger Chartier afirma que con esa categoría se ha vuelto posible dar cuenta de

en primer lugar, las operaciones de clasificación y designación mediante las cuales un poder, un grupo o un individuo percibe, se representa y representa el mundo social; a continuación, las prácticas y los signos que apuntan a hacer reconocer una identidad social, a exhibir una manera propia de ser en el mundo, a significar simbólicamente un estatus, un rango, una condición; y, por último, las formas institucionalizadas por las cuales unos 'representantes' (individuos singulares o instancias colectivas) encarnan de manera visible y durable, 'presentifican', la coherencia de una comunidad (2002:2).

\footnotetext{
${ }^{5}$ Quizás sea preciso aclarar que si bien la obra pionera -y de lectura obligada- editada por Eric Hobsbawm y Terence Ranger en 1983 fue una de las primeras en "interrogarse acerca del papel que juega la tradición dentro de una forma de organización jurídico-política y cultural (el estado-nación) que se adjudica 'raíces profundas' para convertir valores relativos y contingentes en verdades absolutas, universales, atemporales", el presente trabajo toma cierta distancia de este enfoque interpretativo en la medida que "el volumen en su conjunto deja flotando en el aire la sensación de que toda tradición inventada es necesariamente "non sancta'."

Con excepción del estudio de Ranger, "existe entre los colaboradores del volumen la idea de que los observadores se limitan fundamentalmente a 'descubrir' o 'identificar' qué es genuino y qué no -una serie de empresa desmitificadora- como si el carácter espurio o genuino de ciertas tradiciones existiera "aparte" de la interpretación científica (...) no solo se corre el riesgo de que cualquier proceso de simbolización social sea visto como maquinación orquestrada, sino el de asumir que los 'sujetos' tienen la historia en sus manos (...). Como demostrarán los ecos producidos por trabajos posteriores (...) el problema aquí radica en que no sólamente (sic) 'tradiciones' activadas ponen en juego una cierta idea de continuidad simbólicamente construída (sic). El mismo juicio experto acerca de qué prácticas merecen el rótulo de 'genuinas' o 'antiguas' habilita y queda preso de la contienda política por medio de la cual continuidades particulares se sancionan o deniegan” (Briones, 1994: 101-104).
}

6 A este respecto, cabe reponer la postura de Daniel James (1997), según el cual "la memoria posee una dimensión intrínsecamente política derivada de su relación con las estructuras de poder económico, social y político" (1997: 1411. Traducción mía). 
En esta línea y frente a quienes llaman la atención sobre la naturaleza maniquea, doctrinaria o trivial de las ceremonias y celebraciones conmemorativas patrias, reduciéndolas a meros instrumentos ideológicos al servicio de intereses políticos, propongo en las páginas que siguen una reflexión que, insistiendo sobre algunos de sus atributos centrales, concibe a aquellas como un complejo entramado de acciones creativas -de carácter sensible e instrumental, estético y político- que suponen un doble movimiento de encubrimientos y descubrimientos, no necesariamente cerrado, fijo y/o coherente, cuyos objetivos, resultados y exigencias se distancian del de otro tipo de acciones creativas ligadas al problema de la construcción histórica como la labor historiográfica.

A propósito de esto y, en estrecha relación, de las "interpretaciones políticas de la historia" y la capacidad que tienen las conmemoraciones de trazar paralelismos y afinidades entre acontecimientos situados en temporalidades distantes, se ha señalado que

La impertinencia de esas analogías no puede perturbar más que a los historiadores que sostienen sus pruritos de temporalidad como condición sine qua non de su profesionalidad, pero no a quienes quieren establecer una verdad política, un hallazgo estético o una reflexión filosófica. El transcurso del tiempo que, para los historiadores profesionales pareciera ser el meollo de su distinción, puede ser pensado desde la política, como una mera accidentalidad (Bisso y Kahan, 2014:15).

Por otra parte, entiendo que las ceremonias conmemorativas resultan interesantes puntos de entrada al clima político y cultural de una sociedad en una época determinada, las cuales, lejos de ser espejos de los procesos políticos y sociales, intervienen de manera creativa en su producción (Jelin, 2002; Rabotnikof, 2009; Ortemberg, 2013). Por último, advierto que el recorrido que aquí se propone descansa "en la convicción de 
que los productos de la memoria, como cualquier otro conjunto documental, deben ser asumidos (...) con una imprescindible distancia crítica” (Cattaruzza, 2011: 1). ${ }^{7}$

Teniendo todo esto en cuenta, propongo recuperar una de las tesis formuladas por Paul Ricoeur en La memoria, la historia, el olvido (2013), en donde elaboró una mirada alternativa a, por un lado, las posturas que, apoyadas en operaciones científicas, defienden el poder absoluto de la historia profesional al momento de desentrañar lo verdadero (como lo son los casos de Pierre Nora, Yosef Yerushalmi y François Hartog) y, por el otro, las tesis narrativistas que, apropiándose de la teoría literaria para pensar la narración histórica, difuminan las fronteras que solían separar a la historia de las obras de ficción (siendo Roland Barthes, Hayden White y Jaques Derrida sus mayores exponentes).

Desde ese lugar intermedio, el filósofo francés vuelve, entonces, sobre la pregunta por la representación del pasado y, más puntualmente, sobre la polémica relación entre historia y memoria. Tomando distancia de quienes proclaman la supremacía de la historia respecto de la memoria (y viceversa), Ricoeur reivindica, en cambio, el lugar que ambas guardan en los vínculos que las sociedades mantienen con el pasado.

Sin embargo, esa ausencia de jerarquías entre la una y la otra no lo conducen a diluir las diferencias que las separan ni a confundir sus competencias específicas o funcionamientos internos. En este punto, la síntesis elaborada por Chartier, al referirse a la tesis de Ricoeur, resulta particularmente esclarecedora:

El saber histórico puede contribuir a disipar las ilusiones o los desconocimientos que durante largo tiempo han desorientado a las memorias colectivas. $\mathrm{Y}$ al revés, las ceremonias de rememoración y la institucionalización de los lugares de memoria han dado origen a menudo a investigaciones históricas originales. Pero no por ello memoria e historia son identificables. La primera es conducida por las exigencias existenciales de las comunidades para las que la presencia del pasado en el presente es un elemento esencial de la construcción de su ser colectivo. La

\footnotetext{
7 En relación a esto, las palabras de Pierre Nora (2018) también resultan pertinentes: "Es inevitable que el historiador -que no es un hombre abstracto, sino un hombre de su familia, de su religión, de su país- no pueda desprenderse de todas esas circunstancias para ser lo que en otros tiempos se creía que era un historiador, a saber, un hombre de ningún tiempo y de ningún país. Eso es imposible. Pero, al igual que un etnólogo, debe hacer un gran esfuerzo para no estar condicionado por esas dificultades y para intentar una forma no de objetividad, porque no existe, sino de honestidad." Disponible en: https:// www.letraslibres.com/espana-mexico/revista/entrevista-pierre-nora-el-historiador-es-un-arbitro-lasdiferentes-memorias\#.XRBSerk4W3Y.facebook
} 
segunda se inscribe en el orden de un saber universalmente aceptable, «científico», en el sentido de Michel de Certeau (2007; 38-39).

Por lo tanto, es posible afirmar que, a diferencia de los relatos producidos por la historia profesional, aquellos otros tramados y exhibidos durante una ceremonia o celebración conmemorativa no responden a lo que Hans Blumenberg (2008) denominó como "curiosidad teórica" ni mucho menos a la obligación de presentar un sistema de hipótesis, sino que -como apunta Beatriz Sarlo (2007a) a propósito de las modalidades no académicas de narración sobre el pasado- estos se empeñan en ofrecer certezas y asegurar ciertos sentidos, operaciones que -retomando los argumentos de Ricoeur y Chartier- se enmarcan en las "exigencias existenciales" de toda comunidad. 8

Pero ¿cómo es que dichas prácticas pueden contribuir, en ocasiones, a cumplir con tales requerimientos? Paul Connerton (2012) señala que las ceremonias conmemorativas comparten dos rasgos con las formas rituales en general: el formalismo y la performatividad, 9 gracias a los cuales devienen dispositivos mnemónicos. No obstante, continúa el autor, las conmemoraciones constituyen un tipo particular de ritual que difiere del resto en la medida en que aluden a figuras o acontecimientos prototípicos -ya sean míticos o históricos- para el grupo, siendo ésta la razón por la cual poseen, a su vez, otro atributo específico a ellas: la "re-presentación ritual” (ritual re-enactment).

Según Connerton, la "re-presentación ritual" - a saber, la capacidad de hacer reaparecer fragmentos icónicos del pasado que han desaparecido por medio de la repetición calendaria, verbal y corporal- deviene esencial en el tramado y arraigo de

\footnotetext{
${ }^{8}$ Más allá de que memoria e historia no constituyan campos "identificables", esto no me conduce a oponerlos. Sobre este asunto, cabe subrayar especialmente la posición de Andreas Huyssen, para quien "el problema no se soluciona por la simple oposición de una memoria seria enfrentada a una trivial, de manera análoga a lo que a veces hacen los historiadores cuando oponen historia a memoria tout court, memoria en tanto esas cosas subjetivas y triviales que sólo el historiador transforma en un asunto serio (...) esa operación no estaría sino reproduciendo en un nuevo hábito la vieja dicotomía entre lo alto y lo bajo de la cultura modernista" (2002: 24-26).
}

9 Esto es, su carácter normativo y su potencial (re)creativo. 
una tradición y una memoria compartida, ${ }^{10}$ lo cual, en última instancia, favorece la cohesión grupal al contribuir a la conformación y consolidación de las identidades colectivas, así como a su preservación y continuidad a través de las generaciones. ${ }^{11}$

Esta dimensión -y eficacia- simbólica-cultural de la conmemoración se encuentra necesariamente entrelazada a su naturaleza política. Son muchos los autores que han insistido en que la capacidad para cohesionar un grupo, al igual que para conservar y reproducir cierto arreglo identitario, contribuye -por medio de énfasis y acentos, silencios y olvidos deliberados- al sostenimiento y legitimación de un determinado orden político-ideológico y ciertas jerarquías sociales.

Ahora bien, esta arista conservadora y normativa no agota el contenido ni el potencial político de estos dispositivos. Los discursos, las prácticas y las representaciones que circulan en el marco de una conmemoración dirigida por el Estado no solo pueden verse reapropiados, disputados o rechazados desde abajo, sino que, en ocasiones, aquellos mismos pueden servir al cuestionamiento y reformulación del orden social, las identidades y las cosmovisiones heredadas. Es decir, pueden constituirse en canales a partir de los cuales -ya sea desde arriba o desde abajo- las sociedades, al revisar, repensar y re-presentar su vínculo con el pasado, comienzan a conjugar otro porvenir.

En este sentido, cabe reparar en la preocupación de Pablo Ortemberg a la hora de analizar los rituales de poder en la Lima colonial. Apoyándose en los estudios de

\footnotetext{
10 En lo que refiere al concepto de tradición, me interesa reparar en los aportes de Hans-Georg Gadamer. Según el filósofo alemán, el pensamiento rememorante es el que habilita un acercamiento a aquella por medio de su comprensión, interpretación y, por lo tanto, transformación. Pero además de conectar al hombre con el pasado y la tradición -desde la cual piensa y en la cual se encuentra arrojado-, este proceder ofrece la posibilidad de trazar un proyecto que lo lance hacia el futuro. De modo que recuerdo, historicidad y proyecto van necesariamente de la mano: "como seres finitos, estamos en tradiciones, independientemente de si las conocemos o no, de si somos conscientes de ellas o estamos lo bastante ofuscados como para creer que estamos volviendo a empezar (ello no altera en nada el poder que la tradición ejerce sobre nosotros). Pero sí que cambia algo en nuestro conocimiento si arrastramos las tradiciones en las que estamos y las posibilidades que nos brindan para el futuro, o si uno se figura que puede apartarse del futuro hacia el cual estamos viviendo ya, programar y construir todo de nuevo. Por supuesto, tradición no quiere decir mera conservación, sino transmisión. Pero la transmisión no implica dejar lo antiguo intacto, limitándose a conservarlo, sino aprender a concebirlo y decirlo de nuevo" (1991: $54)$.

11 Respecto al concepto de identidad, este estudio retoma los aportes de los aportes de Gerardo Aboy Carlés (2001) quien, al discurrir sobre las identidades políticas, señala tres dimensiones centrales: la de la alteridad, definida como la divergencia específica -aunque nunca rígida, sino más bien difusa y superpuesta- respecto a los otros; la de la hegemonía o representativa, que contribuye a que un grupo adquiera cierta homogeneización; y la de la tradición o la diacrónica, vinculada a los modos en que toda identidad revisa su pasado y su futuro en función de las exigencias del presente.
} 
Raymond Williams, el autor plantea la necesidad de discutir la idea de sentido común que afirma que "por tratarse de fiestas dirigidas desde el poder mismo, no presentan ninguna amenaza para el statu quo" cuando, en verdad, "los procesos hegemónicos siempre encierran su propia contra hegemonía, es decir, una visión alternativa del mundo que desafía a la estabilidad del consenso ideológico" (2014: 23-24).

$\mathrm{Si}$ acordamos que las representaciones del pasado son un aspecto igualmente importante en la lucha por la hegemonía y que las ceremonias conmemorativas organizadas desde arriba pueden -entre muchas otras cosas- intentar disputar las construcciones dominantes en torno a la memoria histórica y la identidad nacional, entonces estos dispositivos resultan escenarios de lucha simbólica e ideológica en donde se pone en juego una y otra vez la construcción del ser colectivo.

Los análisis de Victor Turner (1982; 1986), Georges Balandier (1994), Richard Schechner (2011) y Diana Taylor (2015) -vinculados a la antropología simbólica y política y a los estudios de performance- posibilitan, asimismo, arrojar luz sobre las maneras en que las ceremonias y celebraciones conmemorativas hacen a la existencia de una comunidad.

En sintonía con Connerton, sus contribuciones han autorizado a pensar a aquéllas como performances, ritualizaciones o puestas en escena transitorias -vivas y corporales, cargadas de herencias y tradiciones a restaurar- que permiten expresar y reconstruir la memoria histórica; erigiéndose en "lugares de la memoria" o "bastiones" materiales, simbólicos y funcionales sobre los cuales afianzarse, restituir el pasado y actualizar la identidad colectiva (Nora, 2008).

Así pues, nos encontramos nuevamente con la dimensión performativa de las conmemoraciones, esto es, con su capacidad para reactivar, recrear y transmitir selectivamente determinadas memorias, representaciones colectivas y tradiciones que sostengan, modifiquen o, incluso, contradigan los elementos fundamentales del orden hegemónico vigente (Williams, 2009).

De modo que las ceremonias y celebraciones conmemorativas surgen como actos de transferencia que facilitan la extensión y redefinición de saberes sociales, tradiciones, memorias e identidades a través de prácticas simbólicas y corporales restauradas o lo que Richard Schechner (2011) denomina “conductas realizadas dos veces" (twice- 
behaved behavior). Llegado a este punto, es preciso especificar el sentido que el autor otorga a la noción de restauración, el cual será recuperado a lo largo de este trabajo.

Al discurrir sobre el performance como conducta restaurada, Schechner afirma que ésta "ofrece a individuos y a grupos la posibilidad de volver a ser lo que alguna vez fueron o, incluso, con mayor frecuencia, de volver a ser lo que nunca fueron pero desearon haber sido o llegar a ser" (Schechner, 2011: 39). Es en virtud de ello que las restauraciones, repeticiones o re-presentaciones de una conducta, memoria o figura separadas de sus contextos de origen, tergiversadas e intervenidas- conllevan una profunda fuerza simbólica y reflexiva que explica por qué, lejos de tratarse de acciones vacías, están cargadas de representaciones que se transmiten polisémicamente y tienen el potencial de transformar los espacios socio-políticos.

En "La construcción estética de la realidad. Vagabundos y pícaros en la Edad Moderna", Chartier concluye:

Si es verdadero que las obras estéticas no son jamás meros documentos del pasado, es también verdadero que a su modo, entre veras y burlas, ellas organizan las experiencias compartidas o singulares que construyen lo que podemos considerar como lo real (2002: 15).

¿Qué sucede, entonces, si proponemos entender a las narrativas y escenificaciones desplegadas durante una conmemoración patria como construcciones políticas y sociales, pero también estéticas del pasado y el presente de una sociedad determinada? Quizás así sea posible concebir a la reactualización de la memoria histórica como un proceso tan intrincado como necesario que -provisto del poder de la ficción y la realidad- contribuye a la producción, organización y redefinición del mundo sociocultural.

De esta manera, planteo la necesidad de un acercamiento a dicho objeto de estudio que permita ir más allá de su concepción como simple mecanismo de dominación o artificio político-normativo $\mathrm{y}$, así, recuperar también su carácter afectivo, estético y performativo: el hecho de poder constituirse en instancias de sociabilidad lúdica e integración social, elaboración afectiva y construcción de sentido histórico al dar lugar y 
escenificar memorias y proyectos comunes; a fin de cuentas, el hecho de ser una de las múltiples maneras en que hombres y mujeres dan significado a su mundo.

De acuerdo con Michel Vovelle, las ceremonias y celebraciones conmemorativas pueden emerger como un "momento de verdad en el que un grupo, o una colectividad investida, en términos simbólicos, por una representación de sus visiones del mundo, purga metafóricamente todas las tensiones de las que es portador" (1985:192). Además de -como señala Paolo Rossi con respecto a la memoria colectiva- ofrecer la "posibilidad de referirse a un pasado dotado de sentido", de "poner sólidos diques de contención a los procesos de disgregación, quebrantamiento, aislamiento, erradicación de su ambiente y de su pasado de los individuos y las comunidades” (2003: 183).

Con todo, esto no significa que se pierdan de vista ciertos límites y riesgos inherentes a estas perspectivas. Por un lado, abordar ceremonias o celebraciones conmemorativas conducidas por el Estado como un "momento de verdad" en el que las partes logran fundirse en un todo orgánico nos haría extraviar en una ilusión de unanimidad, en una sobreestimación del potencial de las conmemoraciones para anular las particularidades y proyectar lo colectivo. El descuido rousseauniano de pensar a las fiestas emancipadas de las contradicciones relativas a toda formación social supone soslayar que éstas también pueden devenir experiencias capaces de agrietar la idea de comunidad al exteriorizar los conflictos sociales y políticos.

Por el otro, concebirlas solamente como "diques de contención a los procesos de disgregación" del pasado y presente de una comunidad nos podría llevar a olvidar las numerosas oportunidades en que, para alcanzar tales fines, éstas -revestidas o no de rasgos autoritarios- intentaron funcionar como mecanismos de control dirigidos a ratificar ciertas relaciones de dominación.

En este sentido, la propuesta aquí esbozada no busca idealizar o esencializar el mundo de las conmemoraciones y celebraciones patrias ni desatender el análisis crítico de la función ideológica y disciplinante presente en ellas. En cambio, pretende reponer junto a esas funciones- su dimensión sensible a fin de entenderlas en tanto productos históricos que actúan como reservorios de sentidos y experiencias sociales, estéticas y políticas fundamentales al momento de reforzar, legitimar y/o disputar posiciones y ordenamientos políticos-ideológicos, pero también a la hora de generar sentidos 
históricos, pertenencias y formas de encuentro, habilitando la (re)construcción y cimentación de las identidades colectivas, así como la renovación, confirmación o transformación del orden social y cultural.

\section{Antecedentes}

Proponer un análisis sobre los sentidos políticos, estéticos y culturales activados durante las celebraciones oficiales de los bicentenarios de "independencia" en Argentina, Bolivia, Ecuador y Venezuela -precisando no solo la forma de las conmemoraciones, sino planteando una aproximación comparativa y crítica a éstas en términos tanto sincrónicos como diacrónicos- exige necesariamente un diálogo con el corpus bibliográfico forjado en torno a las fiestas patrias y los procesos de construcción simbólica de la nación que trascienda el recorte temporal de la presente investigación.

Se trata, por lo tanto, de un intento doble: rastrear, sistematizar y comparar la literatura sobre celebraciones patrias, así como identificar los modos en que las prácticas conmemorativas, las memorias históricas y las identidades nacionales han ido redefiniéndose históricamente. Por consiguiente, lo que se pretende aquí es organizar un estado de la cuestión que visibilice y examine la configuración de un campo historiográfico forjado en torno a las fiestas patrias en los casos aludidos y, a la vez, sintetice los rasgos centrales que adquirieron éstas en distintos períodos históricos a fin de poder precisar, en torno al objeto central y específico de nuestra indagación -las conmemoraciones de los bicentenarios- si existen y en qué medida, continuidades, rupturas o desplazamientos de sentido.

En este sentido, debemos recordar que ya hacia finales de la década de los ochenta, la historiografía sobre fiestas patrias en América Latina comenzó a experimentar una lenta pero sostenida renovación en el campo de la historia política y cultural. Los festejos del bicentenario de la Revolución Francesa, las conmemoraciones del quinto centenario de la conquista de América y, finalmente, la proximidad de los 
doscientos años de las revoluciones de independencias hispanoamericanas transformaron a las prácticas festivas y conmemorativas en atractivos puntos de entrada a la hora de discutir la relación entre Estado, nación y sociedad en una época determinada. 12

En este contexto, cuando la comunidad académica se propuso echar luz sobre el complejo problema de la construcción de los Estados-nación y los mitos de origen en América Latina a través de sus rituales conmemorativos, fue naturalmente el período de la Hispanoamérica posrevolucionaria uno de los primeros en ser estudiado. En relación a la Argentina, Tulio Halperín Donghi esbozó, en su consagrada obra Revolución y guerra, que las primeras "Fiestas Mayas" tuvieron un rol destacado en la creación de una nueva liturgia revolucionaria:

En esos años afiebrados, gracias a la colaboración de un poder ansioso de afirmarse y de la parte de la población que le es adicta, una nueva liturgia revolucionaria ha sido creada; si algunas de sus manifestaciones son efímeras (...), las más de ellas están destinadas a perdurar: los festejos del 25 de mayo, de desarrollo primero paralelo a las festividades devotas tradicionales, terminan por rivalizar con éxito con éstas; treinta años después de la revolución, cuando el desterrado Juan María Gutiérrez quiere explicar a su hermana, residente en el Buenos Aires rosista, el lugar de las fiestas patronales en la vida de una aldea de Italia septentrional, le propone una comparación: 'es el 25 de mayo de estos pueblitos'; hasta tal punto que la fiesta cívica - momento culminante de la nueva liturgia revolucionariasigue siendo, con la revolución ya relegada resueltamente en el pasado, el máximo festejo colectivo conocido por Buenos Aires (2005a [1972]: 173).

Posteriormente, el destacado historiador Juan Carlos Garavaglia (2000) profundizó en los orígenes de la nación a través de los primeros festejos del 25 de mayo desplegados en la ciudad de Buenos Aires y su zona de influencia a partir de 1811, los cuales comenzaron a denominarse "Fiestas Mayas" luego de la Asamblea del año 13. El análisis del contenido lúdico y simbólico de los festejos le permitió identificar una mezcla de tradiciones ibéricas y locales dirigidas a forjar una nueva identidad, así como la presencia de una lógica que combinaba autonomía popular y dirección desde arriba.

12 Cabe señalar que muchas de estas investigaciones se vieron fuertemente influenciadas por ciertos estudios clásicos sobre festividades como Duvignaud (1973), Ozouf (1976), Vovelle (1976), Agulhon (1977) y Chartier (1979). 
Los aportes de Gabriel Di Meglio (2001, 2007) -quien reflexionó sobre la participación de la plebe en las celebraciones de la primera década revolucionaria-, María Lía Munilla Lacasa (2013) - la cual analizó el arte efímero producido para las fiestas cívicas en Buenos Aires durante el período revolucionario (1810-1816)-, Fernando Gómez (2013) -quien recurrió a las "Fiestas Mayas" desplegadas entre 1811 y 1836 para pensar su rol en la legitimación de los gobiernos que las organizaban- y Ricardo Salvatore (1996) -que abordó las fiestas federales ocurridas en la provincia de Buenos Aires durante el Rosismo- refuerzan aquella idea de "indefinición simbólica" y recalcan que las fiestas constituían verdaderos espacios de participación popular, comunicación y negociación política.

Estas tendencias se mantendrían hasta los inicios del proceso de consolidación nacional cuando, ya sin la espontaneidad y emoción popular de antaño, las fiestas patrias comenzarían a mutar y adquirir tonos más solemnes. Así lo indica la historiadora Lilia Ana Bertoni (1992, 2001), quien mostró cómo las celebraciones tuvieron, junto a la escuela, un papel central a fines del siglo XIX en el disciplinamiento, integración y nacionalización de una sociedad de orígenes étnicos diversos.

Respecto a Venezuela, la investigadora del Centro Nacional de Historia, Leonor De Freitas (2010), también encuentra que el establecimiento de efemérides y referentes históricos comunes se volvió una necesidad urgente al momento de apaciguar y dirimir los conflictos interclasistas y la inestabilidad política que sacudían a la joven república. Para la autora, las fiestas cívicas funcionaban, ante todo, como instrumentos de las élites políticas dirigidos a seducir a los distintos grupos sociales. No obstante, bajo aquel clima de fragilidad institucional, se volvería difícil lograr continuidad en la celebración del 19 de abril, quedando a discreción de los gobiernos de turno en la medida que las circunstancias políticas, militares y naturales lo permitieran.

En este contexto, la figura de Bolívar surgiría, recién a partir de 1842, como elemento de unificación y reconciliación nacional (Mc Evoy, 2006; Carrera Damas, 2008; Quintero Montiel, 2015). Sin embargo, el culto al Libertador llegaría a su punto cúlmine en tiempos del general Guzmán Blanco -puntualmente, en 1874 con la inauguración de una estatua ecuestre en Caracas-, cuando las fiestas patrias devinieron parte fundamental de su proyecto modernizador, centralizador y de pacificación 
nacional. Éstas, acompañadas de un auge arquitectónico y monumentalista -y vaciadas de contenido religioso al eliminarse el Te Deum-, revistieron una función didácticomoralizante, sirviendo también a la exhibición del progreso material alcanzado bajo el guzmancismo (Calzadilla 1999; Salvador González, 2006, De Freitas, 2010).

La historiografía boliviana dedicada al estudio de los orígenes de las fiestas republicanas presenta un desarrollo más bien escaso y, sobre todo, reciente. No obstante ello, es posible conocer cuáles fueron algunos de sus rasgos centrales a partir de los trabajos de la historiadora y miembro de la Academia Boliviana de Historia, Eugenia Bridikhina $(2007 ; 2010)$. Según la autora, el controvertido calendario cívico nacional surgido tras una larga guerra de independencia tampoco significó una ruptura total con la tradición festiva española.

Así, las mismas prácticas rituales y simbólicas que habían sido eficaces a la hora de fundar la legitimidad monárquica -juras, Te Deum, estatuas ecuestres, retratos y festejos de cumpleaños- serían recuperadas y combinadas con el repertorio simbólico de la Francia revolucionaria a fin de reactualizar las identidades colectivas. En este marco, uno de los rasgos centrales del programa cultural republicano fue el culto guerrero, el cual combinaba desfiles y recibimiento de autoridades a modo de adventus, un ritual propio de la época colonial que involucraba a todos los sectores de la sociedad y servía para entablar el diálogo entre la autoridad y el pueblo.

De este modo, se asentaba, según Françoise Martínez (2005), un modelo de "fiesta cesariana" que exhibía la fuerza del vínculo entre el pueblo y su jefe militar, que -por medio del Decreto del 11 de agosto de 1825- daba su nombre al nuevo Estado: República Bolívar. Sin embargo, la autora sugiere que los festejos patrios no se volverían populares sino hacia la mitad del siglo XIX cuando, a partir de la presidencia de Manuel Isidoro Belzu y su exaltación del 6 de agosto como principal efeméride nacional con el objetivo de promover la unidad, el civismo y el patriotismo (en tanto era una fecha que evitaba referencias a batallas y héroes particulares), se amplió la participación de distintos sectores sociales cuya lealtad al régimen se pretendía alcanzar, justamente, a través de los festejos.

Como apunté para el caso boliviano, los análisis sobre la construcción simbólica de la nación ecuatoriana durante el siglo XIX tampoco abundan. En este contexto, se 
destacan los trabajos del historiador Guillermo Bustos $(2010 ; 2011)$, quien afirma que la continuidad con las prácticas festivas de la colonia también fue un rasgo visible en Ecuador, donde la formación, difusión y asimilación de la identidad nacional tuvo, como en los ejemplos anteriores, su punto álgido en el último tercio del siglo XIX.

En un país donde catolicismo y republicanismo no fueron dos proyectos políticos y sociales incompatibles, Bustos observa que las celebraciones de la independencia se vieron atravesadas por elementos tanto cívicos como religiosos, dando origen a una memoria de la nación estrechamente ligada a la Iglesia católica. De hecho, advierte el autor, el Estado republicano solía utilizar como escenario principal de las efemérides públicas al templo católico, exhibiendo una marcada preferencia por las fiestas religiosas.

El resultado de ello fue la construcción política de una subjetividad religiosa de lo patriótico y lo público que perduró hacia finales del siglo XIX cuando, coincidiendo con el centenario del nacimiento de Bolívar y la Revolución Liberal de 1895, las celebraciones cívicas y monumentos conmemorativos comenzaron a adquirir un aspecto más laico (Bustos, 2011; Richard, 2013).

En este complejo proceso de construcción y afirmación de las identidades nacionales, las conmemoraciones de los centenarios de las revoluciones de independencia se convertirían en otro hito trascendental y, ciertamente, la exaltación de las glorias pasadas sería un rasgo central de los festejos. En Argentina, esto se reflejó en la ola de inauguraciones de estatuas y monumentos a próceres revolucionarios, particularmente a San Martín que -además de fomentar el culto cívico al interior del país- sirvieron también, según Pablo Ortemberg (2015), para forjar alianzas internacionales en un contexto en el que los conflictos limítrofes se encontraban todavía vigentes. La narrativa sanmartiniana posibilitaba, así, aumentar la influencia argentina en los Estados del Pacífico, al tiempo que socavaba el dominio continental de Brasil.

De todos modos, gran parte de la literatura sobre el tema coincide en señalar que el centenario devino, fundamentalmente, una celebración modernista que, reconciliada con la "herencia española" e inspirada en las ideas de progreso tecnológico y científico que impregnaban a todo Occidente, estuvo dirigida a proyectar una imagen de prosperidad, poder y optimismo hacia el mundo (Altamirano y Sarlo, 1980; Gutman, 
2005; Fernández Bravo, 2006; Malosetti Costa, 2010; Suriano, 2010; Álvarez Sepúlveda y Martínez Llamas, 2014; Devoto, 2014).

Es que la Argentina del centenario parecía haberse convertido en el "granero del mundo", a la vez que había desarrollado una avanzada infraestructura, lo cual fue exhibido en la Exposición Internacional del Centenario que tuvo lugar desde mayo a septiembre de 1910 y estuvo financiada por la Sociedad Rural Argentina y la Unión Industrial Argentina. Sin embargo, detrás de esa fachada triunfalista de festejo y modernización excluyente, se agudizaba el conflicto social, y la festividad-ocurrida bajo estado de sitio- lejos de velar los conflictos, los situó en el centro del espacio público (Gorelik, 1997).

En cuanto a los aportes de la historiografía ecuatoriana, éstos permiten observar de qué manera la posición que la Iglesia católica mantuvo a lo largo del siglo XIX comenzó a desmoronarse ante el avance del proceso de centralización estatal, integración nacional y redefinición del campo simbólico de la nación impulsado por la revolución liberal de Eloy Alfaro; proceso que se acentuaría durante los preparativos de la conmemoración del primer centenario de la Revolución de Quito (Ospina Peralta, 1996; Carcelén Cornejo et al, 2006; Bustos, 2010; Coronel y Prieto, 2010).

Algunos de los ejes en torno a los cuales giraron las celebraciones fueron la realización de exhibiciones a la usanza de las exposiciones universales de fines del siglo XIX, la publicación de libros con mapas y fotografías de las ciudades, la construcción de monumentos -siendo el más emblemático el monumento a los "héroes del 10 de agosto" en Quito en 1906, para el cual se apeló a la figura local del cóndor como símbolo de la libertad- y, finalmente, el ferrocarril trasandino, símbolo clave del liberalismo que despertó una vigorosa oposición política conservadora y clerical.

Bajo la intensa activación cultural que supuso el centenario, Blanca Muratorio (1994), Pablo Ospina Peralta (1996) y Mercedes Prieto (2004; 2010) -interesados en el problema de la integración social, política y cultural de los indígenas- encuentran que estos comenzaron a verse paulatinamente incluidos en los discursos sobre la nación a partir de alegorías asociadas a la producción y al trabajo, al tiempo que empezaban a reivindicarse las aristocracias indígenas precoloniales y a ligarlas al sustrato español nuevamente presente en la narrativa nacional. En este modelo de inclusión desde arriba 
en la idea de nación que empezó a construirse en el Ecuador del centenario, el rol y la sociabilidad del artesanado urbano y las mujeres - de distintos sectores sociales- se vieron, asimismo, modificados (Coronel, 2010; Goetschel, 2010; Herrera; 2010).

Respecto al caso venezolano, Leonor De Freitas insiste, en su ya citada obra Centenario del 19 de abril (1810-1910), que la importancia dada por la historiografía venezolana a la conmemoración del 19 de abril de 1910 ha sido escasa; la cual fue abordada, por lo general, como un tema complementario a otros estudios. Con vistas a remediar ese vacío, la autora se abocó, entonces, al análisis de los mencionados festejos y advirtió que la institucionalización del 19 de abril como día inicial de la revolución de independencia se produjo, precisamente, durante la celebración de su centenario bajo la presidencia de Juan Vicente Gómez, quien aprovechó la ocasión para convertir en motivo de festejo nacional tanto la gesta independentista como su llegada al poder.

La labor de dicha historiadora, sumado a algunos estudios provenientes de la arquitectura (Calderón Trejo, 2011) y las artes plásticas (Esteva-Grillet, 2010), así como del campo de la literatura y la retórica (Affigne Oropeza, 2015) sostienen que la proyección y construcción de diversas obras públicas en la capital venezolana -además de realzar el valor del arte, la ciencia, la tecnología, la higiene y la salubridad, la información y la comunicación- estuvieron dirigidas a exhibir el progreso material de la República, denotar el orden público y legitimar la gestión del presidente Gómez.

Los trabajos de investigación realizados en la historiografía boliviana sobre las conmemoraciones centenarias de 1909 y 1925 resultan, como ocurre para el siglo XIX, exiguos. En este sentido, son los análisis de Françoise Martínez (2013a; 2013b) los que nuevamente permiten echar luz sobre el período en cuestión.

Según la historiadora francesa, la pérdida del Litoral, la existencia de litigios fronterizos irresueltos y el clima de disputa entre liberales y conservadores hicieron que, desde fines del siglo XIX, fortalecer la unidad nacional boliviana se volviera una necesidad urgente. Para ello, el gobierno liberal de José Manuel Pando decretó en 1903 que todas las fiestas patrias locales se supeditaran a la del 6 de agosto, fiesta y feriado nacional único capaz de preservar la paz y la unidad interregional, así como materializar la nación en un imaginario colectivo común. 
Paradójicamente, aunque la unidad y estabilidad eran considerados requisitos de una nación civilizada, la construcción identitaria realizada por las élites durante los festejos centenarios -en los que se siguieron las tendencias latinoamericanas de inaugurar exposiciones, obras públicas y monumentos- continuó caracterizándose por la exclusión étnica que desde principios del siglo XX marcaba, según la autora, a las fiestas cívicas.

Es que, en un intento por proyectar hacia el exterior una imagen de nación moderna y facilitar su inserción al concierto de Estados-nación blancos, cultos y civilizados, las festividades desplegadas a partir de ese momento por las élites criollas en el poder no remitían "a la totalidad de los bolivianos sino más bien a las clases urbanas acomodadas", aislando así a la mayoría indígena y mestiza de la imagen de nación (Martínez, 2013a; 2013b).

De cualquier modo, los anhelos de unidad nacional entrarían, para ese entonces, en crisis: centradas en La Paz, las celebraciones reactivaron la rivalidad regional con Sucre -quien llamó a boicotear la festividad-, al tiempo que ocasionaron fuertes críticas por parte de una nueva generación de obreros, militares y estudiantes antiliberales que disputaría el sentido de bolivianidad vigente (Stefanoni, 2015a).

\section{La especificidad bicentenaria}

No llama la atención que -como sucedió con los centenarios- las celebraciones de los doscientos años del inicio de los procesos de independencia comenzaran a despertar el interés de investigadores procedentes de las humanidades y ciencias sociales, pero también del campo del arte. Respecto al bicentenario argentino, María Belén Sotelo (2011) sostiene que el éxito y la masividad de la celebración se deben entender a partir de un intento de inclusión identitaria en el que, lejos de temerle a la diversidad, ésta fue retomada desde el Estado para interpelar al pueblo, extender la idea de nación y revalorizar el espacio público. Así, las celebraciones oficiales habrían constituido un momento de ruptura con las narrativas de la nación blanca y de visibilización de lo diverso y lo no-europeo (Adamovsky, 2012; Citro, 2017). 
Para ello, el gobierno recurrió a una serie de recursos estéticos y escénicos menos convencionales e interactivos (Pagano y Rodríguez, 2015). Un ejemplo de esa búsqueda fue el videomapping proyectado sobre el Cabildo de Buenos Aires, el cual -a partir de una interacción entre arte audiovisual, memoria colectiva y arquitectura- promovió una cultura festiva y espectacular, así como un uso novedoso del espacio público (Ortemberg, 2013). O el desfile artístico-histórico realizado por Fuerza Bruta que, para Malala González (2015), permitió observar cómo la política cultural kirchnerista pretendió espectacularidad, sensibilidad y emoción a un "conocimiento certero de la historia política”.

La socióloga Norma Giarracca (2011) coincide en señalar que las puestas en escena sobre la historia argentina exhibidas durante el festejo bicentenario fueron sorprendentes no sólo por el nivel artístico, sino también por su contenido filosóficopolítico. Sin embargo, sostiene -a diferencia de los otros investigadores- que el gobierno "mostró la hilacha" al proponer una imagen de futuro homogénea y ordenada, sin respeto hacia las diferencias culturales, étnicas o regionales, y al desplegar un modelo de país donde el poder globalizado habría tenido mayor fuerza que los lazos culturales.

Si bien las puestas en escena visibilizaron prácticas culturales y actores sociales antes relegados, el festejo se habría tratado de una "explosión" dirigida y disciplinada de la diferencia, en tanto esta última fue exhibida de manera estetizada, apolítica y ahistórica (Thomasz et al, 2011). En esta línea, el trabajo etnográfico producido por Mario Rufer (2012) plantea que la narración histórica desplegada durante los festejos oficiales del bicentenario - cuya estética, según el historiador, rozó la vulgaridad-acabó siendo un mosaico de presencias fragmentadas, donde la diversidad -particularmente, afrodescendiente e indígena- fue incorporada bajo la lógica de la escena para ser "domesticada" como cultura y ubicada en el terreno de la diferencia.

Según otros investigadores, el rasgo principal a la hora de interpretar el bicentenario de la Revolución de Mayo fue la polarización de la escena política promovida por el gobierno kirchnerista y reflejada en la antinomia izquierda/derecha, sobre todo luego del conflicto con el "campo" en el año 2008 (Perochena, 2013). En este sentido, la oposición bicentenario/centenario sirvió a las necesidades del gobierno, 
al permitir ubicar en aquel pasado "antidemocrático y oligárquico" la génesis de los conflictos presentes. Para ello, el gobierno habría realizado una recuperación -selectiva e improvisada- de la visión del pasado esbozada por el revisionismo histórico, la cual habría sido funcional y legitimadora del discurso polarizador kirchnerista (Damilakou, 2013; Stornini, 2015; Suriano, 2015; Molinaro, 2017; Perochena, 2013, 2018).

A contramano de la experiencia argentina, los bicentenarios de Venezuela, Bolivia y Ecuador no suscitaron el mismo interés, motivaron nuevas discusiones ni dieron lugar a análisis en profundidad de la dimensión simbólica y cultural del llamado "giro a la izquierda" en las mencionadas "repúblicas bolivarianas". En Venezuela, Frédérique Langue (2013) observa que, durante los festejos bicentenarios, se profundizó la pretensión por reconstruir -e imponer- una memoria histórica basada en la reinvención del culto a Simón Bolívar.

La historiadora francesa encuentra en los "sucesos" de abril del 2002 un momento bisagra que habría servido a la radicalización del imaginario bolivariano, desembocando, por un lado, en una reactualización del culto al libertador a partir de un discurso populista violento, autoritario y emocional; y, por el otro, en el trazado de un continuum entre Chávez y Bolívar, héroes mestizos y populares de las luchas emancipadoras latinoamericanas. En realidad, más que de un paralelismo simbólico, Langue -alineada a aquellas perspectivas historiográficas que reducen el siglo XIX hispanoamericano al fenómeno de la violencia- advierte sobre la supuesta afinidad electiva entre pretorianismo y caudillismo presente en el "régimen" chavista.

Por otro lado, cabe destacar el trabajo de Yuri Tórrez y Claudia Arce (2014), el cual constituye otra referencia interesante para emprender el análisis del Estado Plurinacional de Bolivia desde un plano simbólico-identitario en tanto recupera tres celebraciones bicentenarias -las de Chuquisaca, Cochabamba y La Paz- como momentos centrales a la hora de aprehender los nuevos sentidos que se activaron con la llegada del MAS al poder y entiende a las divisiones de clase, étnicas y regionales como fundamentales para comprender las especificidades de cada uno de ellos. Sin embargo, el carácter somero de sus reflexiones en torno a las celebraciones bicentenarias lo vuelven más bien un punto de partida para los estudios abocados al análisis de ese momento particular de la historia reciente boliviana. 
En resumen, este acervo bibliográfico exhibe cómo en momentos cruciales de la historia latinoamericana las fiestas patrias condujeron a una presentificación del pasado, en el que los usos políticos de éste devinieron un recurso nodal no solo en los procesos de construcción y legitimación del poder político y de sus filiaciones ideológicas, sino también en la reactualización -siempre conflictiva y paradójica- de las identidades colectivas.

Ahora bien y con respecto al recorrido por el estado del debate en torno a los festejos del bicentenario, éste deja en evidencia la ausencia de una cobertura pareja de la región, así como de análisis integrales y comparados que den cuenta de qué maneras las identidades colectivas han sido reelaboradas, las memorias históricas reactualizadas y, en última instancia, cómo la hegemonía fue disputada durante las celebraciones bicentenarias proyectadas por esos cuatro gobiernos enmarcados en el llamado "giro a la izquierda", siendo este vacío lo que la presente tesis doctoral se propone subsanar.

\section{El enfoque y la estructura de esta tesis}

Este estudio parte, entonces, de la premisa -a estas alturas, evidente- de que las fiestas patrias suponen un insumo fundamental al momento de ahondar en el vínculo entre historia, política y nación en una época determinada. En este sentido, los bicentenarios de "independencia" fueron escogidos por su potencial para entrever algunas dimensiones más generales de la experiencia histórica formada por el llamado "giro a la izquierda" en América del Sur; especialmente, aquellos aspectos referidos a los procesos de construcción hegemónica y revisión de ciertas identidades colectivas activados en Argentina, Bolivia, Ecuador y Venezuela bajo las aludidas circunstancias conmemorativas, así como a los conflictos, tensiones y contradicciones que, naturalmente, acompañaron esos empeños.

De esta manera y respecto a la decisión de hacer una historia de la que quien escribe resulta contemporáneo, Henry Rousso escribía: 
cuando los historiadores pretenden hacer una "historia del tiempo presente", aceptan ipso facto el desafio de dirigir una mirada histórica a su propio tiempo. Quiéranlo o no, practican entonces de manera permanente una forma de "egohistoria". Se ven regularmente enfrentados a la necesidad de poner cierta distancia, a veces artificial, con respecto a su medio cultural y su objeto de estudio, del que en ocasiones están muy cerca. Esta proximidad, que es una fuente de riqueza pero también de problemas específicos, suele ser el origen de la vocación de esos historiadores. Se trata entonces, de manera principal o adyacente, de reflexionar sobre el lugar y la influencia de la producción histórica dentro de la sociedad, e incluso de las expectativas que la rodean (...) (2017: 4).

Teniendo en cuenta esas observaciones y advertencias, se aspiró a construir un enfoque interdisciplinario que se sustentara tanto en una mirada historiográfica como sociológica, pero que también se nutriera y, desprejuiciadamente, hiciera uso de ciertos aportes y herramientas provenientes de la filosofía y la antropología, con el propósito de contribuir a desentrañar -desde múltiples ángulos- los sentidos que rodearon a las prácticas y los discursos acontecidos durante los aniversarios patrios en cuestión pero, sobre todo, a fin de reconocer ciertos rasgos distintivos de estos fenómenos políticos por fuera de las miradas binarias o dicotómicas que han oscilado entre la aclamación y la condena de los mismos.

Asimismo, es preciso advertir que este escrito se aparta de las perspectivas instrumentales y limitadas que identifican en el Estado un mero aparato de control, esto es, de ejercicio de violencia, ya sea en su forma pura o ideológica (Mouffe, 1985). En esta línea, lo que se buscó alcanzar -al momento de pensar al Estado, los usos del pasado y las puestas en escena desplegadas por algunos de sus actores- es justamente una negociación entre una mirada instrumentalista y una subjetivista.

Por otro lado y con vistas a responder a los objetivos propuestos, se planteó una estrategia de investigación de corte cualitativa a partir de la lectura y análisis sistemático de múltiples fuentes: discursos y alocuciones presidenciales y de funcionarios políticos destacados en marcos institucionales y extrainstitucionales, normativas elaboradas por los Poderes Ejecutivos, prensa escrita de tirada nacional, 
crónicas y bitácoras concernientes a las celebraciones bicentenarias, material fílmico de las mismas y literatura secundaria.

A este respecto, cabe prevenir que el criterio de selección de las fuentes se vinculó mayormente al grado de impacto y circulación que tuvieron las mismas durante aquel período conmemorativo. Sin embargo, también se recuperaron algunos documentos y testimonios que -aunque periféricos o de menor alcance- contenían una gran riqueza al momento de trazar un cuadro complejo y representativo de los acontecimientos y fenómenos aquí examinados.

En cuanto a la estructura de la tesis, ésta se encuentra dividida en cinco capítulos. En el primero de ellos, luego de efectuar un repaso sobre los orígenes de las cuatro fuerzas políticas, se reconstruyen y examinan los contextos y procesos políticos e institucionales que -con vaivenes, obstáculos e imprevistos- fueron configurando a los regímenes conmemorativos de los bicentenarios de "independencia" en cada uno de estos países.

De igual modo, se observa cómo aquellas primeras aproximaciones dirigidas a urdir los festejos del bicentenario se tradujeron, finalmente, en expresiones o productos concretos. El capítulo cierra, así, con un recorrido general por los eventos oficiales, esto es, por los programas, escenarios y puestas en escena que formaron parte de las seis propuestas conmemorativas y festivas desplegadas entre 2009 y 2011.

El capítulo dos se concentra fundamentalmente en los usos oficiales del pasado efectuados durante los aniversarios patrios, y cómo se pretendió, a partir de esas operaciones, restaurar las memorias históricas de cada nación, sistematizar las filiaciones ideológicas y afianzar no solo los proyectos políticos, sino también una determinada idea de nación.

Lo que se analizan aquí son, entonces, las formas en que los Poderes Ejecutivos en cuestión se sumergieron en el pasado con el objeto de seleccionar, reinterpretar y representar un abanico de tradiciones, figuras y acontecimientos históricos como sus marcas fundadoras, las cuales les habrían concedido la posibilidad de, entre otras cosas, fortalecer y validar sus idearios, búsquedas e intereses político-ideológicos.

El tercer capítulo propone una reflexión sobre las puestas a punto de los festejos oficiales del bicentenario, es decir, un análisis detallado en torno a las prácticas festivas 
y conmemorativas - de carácter protocolar e institucional, así como popular y masivo- a fin de continuar problematizando los intentos oficiales por celebrar la nación, restaurar las identidades colectivas y legitimar sus proyectos políticos.

No obstante, esta sección se interesa e insiste también en el hecho de que las mismas constituyeron, a su vez, instancias de sociabilidad lúdica, ocio e integración social, lo cual permite complejizar la preeminencia de lo ideológico y lo solemne en el conjunto de prácticas y discursos que esos actores políticos delinearon en ocasión de las celebraciones bicentenarias.

Si todo fenómeno político es relacional, esto significa que para comprender su constitución identitaria es crucial que sean puestos en relación a algunos elementos representativos del "otro" a partir de los cuales buscaron erigirse. Por lo tanto, en el capítulo cuarto se reflexiona sobre el modo en que las prácticas y los discursos conmemorativos oficiales tuvieron lugar en el marco de coyunturas críticas atravesadas por disputas y tensiones con diversos actores de la sociedad, dando lugar a un conjunto de querellas político-ideológicas y/o historiográficas que ocuparon la escena pública y pusieron de manifiesto las resistencias y oposiciones a los sentidos oficiales desplegados durante los festejos patrios.

Finalmente, si bien el quinto capítulo vuelve sobre las maneras en que los Poderes Ejecutivos concibieron las celebraciones de los doscientos años del inicio de las gestas emancipadores, lo hace matizando las similitudes y los paralelismos trazados en las páginas precedentes con el objetivo de identificar y discernir el carácter específico de las identidades, los anhelos y los proyectos políticos de cada una de esas experiencias de gobierno durante el particular momento histórico constituido por los bicentenarios de "independencia". 


\section{Capítulo I}

\section{Política, fiesta y nación bajo un nuevo centenario}

\section{América del Sur en el cambio de siglo. Breves apuntes sobre los orígenes del llamado "giro a la izquierda" en Venezuela, Argentina, Bolivia y Ecuador}

La crisis del neoliberalismo como forma de discurso hegemónico en América Latina sentó las condiciones para que el fin de siglo encontrara a la región en una suerte de encrucijada: además de un campo político conformado por gobiernos que continuaban enmarcados en un modelo de acumulación neoliberal bajo la égida de los Estados Unidos y los organismos internacionales de crédito, fue estructurándose una matriz política-económica de corte posneoliberal en países que -con mayor o menor estridencia- comenzaron a pregonar la necesidad de reducir las desigualdades sociales, producir nuevos imaginarios políticos e ideológicos y desafiar las configuraciones simbólico-identitarias dominantes. ${ }^{13}$

\section{Venezuela}

En este sentido, fue el rotundo éxito del movimiento bolivariano conducido por Hugo Chávez Frías el 6 de diciembre de 1998 lo que marcó el inicio del llamado "giro a

\footnotetext{
13 En palabras de Marcelo Cavarozzi, este cambio de rumbo se vio posibilitado, a partir del 2003, debido a que "el alza en el mercado mundial del precio (y de la demanda) de los commodities mineros y agrícolas exportados por los países de la región les permitió escapar a la trampa de la deuda en la que habían estado liados desde 1980 (...) por ende, (...) los nuevos fenómenos políticos registrados en América del Sur durante la primera década del siglo XXI tienen una explicación relativamente simple: fueron posibles porque los Estados de la región recuperaron el margen de maniobras del cual habían carecido durante las dos décadas previas. Las transformaciones favorables de la economía internacional abrieron una ventana de oportunidad para encarar políticas económicas activas, cualquiera fuera el signo de éstas" (2011:18).
} 
la izquierda" en la región. ${ }^{14}$ Los orígenes del movimiento bolivariano se remontan a los cuarteles militares cuando, a finales de la década del 70, comenzaban a hacerse visible en Venezuela las primeras manifestaciones del agotamiento del modelo rentistapetrolero; escenario que derivó, hacia los 80 y 90, en una profunda crisis social, política e institucional cuyos hitos emblemáticos fueron el Caracazo de 1989, los intentos de golpes de Estado de 1992, la destitución del presidente Carlos Andrés Pérez y el derrumbe del sistema bipartidista en 1993 (Lander y López Maya, 1999; López Maya, $2003 ; 2008)$.

Ese contexto inicial de crisis sirvió de estímulo al surgimiento de diferentes grupos conformados por militares nacionalistas, educados en el culto a Simón Bolívar e imbuidos de cierta concepción desarrollista de la economía, los cuales se lanzaron a criticar, impugnar e, incluso, conspirar en contra del sistema político vigente. Uno de estos incluía, justamente, a Chávez, quien -junto a otros oficiales- fundó en 1983, en ocasión del bicentenario del natalicio de Bolívar, una organización clandestina llamada Movimiento Bolivariano 200 (MBR 200), la cual -dispuesta a confrontar con el “corrompido régimen bipartidista y antinacional de Acción Democrática y COPEI"-15 fue protagonista de la fracasada insurrección del 4 de febrero de 1992.

Tras un bienio en la cárcel, Chávez decidió, una vez liberado, abandonar el ejército para, en cambio, comenzar a disputar el poder político en la arena electoral. Con ese fin, creó en 1997 el Movimiento V República (MVR), una estructura electoral que posibilitara construir alianzas con otras fuerzas políticas de diverso signo ideológico dispuestas a apoyar su candidatura en las elecciones presidenciales de 1998.

Finalmente y para sorpresa de muchos, Chávez consiguió imponerse con más del $50 \%$ de los votos provenientes de una ciudadanía que anhelaba un profundo cambio político en medio de un nuevo descalabro económico ocasionado por la abrupta caída de los precios del petróleo en el mercado internacional (Lander y López Maya, 1999; López Maya, 2003).

\footnotetext{
14 Rotundo éxito electoral en la medida que no solo obtuvo el 56, 2 \% de los votos, sino que ganó con el segundo mayor número de votos y el segundo porcentaje más alto de la historia electoral venezolana.

15 Palabras de la Vicepresidencia de la República Bolivariana de Venezuela en ocasión del $35^{\circ}$ aniversario del nacimiento del MBR 200. Disponibles en: http://www.vicepresidencia.gob.ve/index.php/2018/07/24/ hoy-se-cumplen-35-anos-del-nacimiento-del-movimiento-bolivariano-revolucionario-200/
} 
Bajo estas circunstancias y apoyado en el "árbol de las tres raíces", 16 el nuevo gobierno -rápidamente autoproclamado como la "revolución venezolana de este tiempo"-17 se comprometía a romper con el sistema político tradicional y a refundar el Estado y la nación al tiempo que postulaba al pueblo como sujeto del cambio revolucionario y a las Fuerzas Armadas - con Chávez a la cabeza- como conductoras del mismo (Rojas, 2005; Paramio, 2008).

\section{Argentina}

En el caso de Argentina, la crisis social, económica y financiera de 2001 -que condujo al colapso político-institucional del país e involucró la caída del gobierno de la Alianza sellada con la renuncia de Fernando de la Rúa, así como la sucesión de cuatro presidentes provisionales en menos de una semana- sentó las condiciones de posibilidad para la explosión de diversas modalidades asamblearias, masivas movilizaciones populares y novedosos ethos militantes por fuera del Estado, cuyo posterior declive y fragmentación socavaron las expectativas de una recomposición política "desde abajo" y dieron paso a una firme y generalizada demanda ciudadana de normalidad (Svampa, 2011).

De modo que a principios del 2003 cuando el santacruceño Néstor Kirchner llegaba a la presidencia con solamente el $22 \%$ de los votos en medio de un escenario político y social todavía punzante, 18 lo primero que se propuso fue -apelando a un discurso crítico no solo respecto de los gobiernos anteriores y su impronta neoliberal, sino también de su propia fuerza política, el peronismo- reconstruir la autoridad

\footnotetext{
16 Este fue el nombre que Chávez dio al marco o sistema ideológico detrás del golpe de 1992 y, en términos generales, del movimiento bolivariano, el cual hallaba sus fundamentos en el pensamiento de tres figuras consideradas centrales: Simón Bolívar (líder), Simón Rodríguez (maestro) y Ezequiel Zamora (general).

${ }^{17}$ Expresión utilizada por Chávez tanto en su discurso de toma de posesión de la primera presidencia el 2 de febrero de 1999 como en el discurso pronunciado durante la primera sesión de la Asamblea Nacional Constituyente el 5 de agosto de 1999. Cabe aclarar que faltaría tiempo para que este proceso fuera bautizado como RB e iniciara su tránsito hacia el llamado "socialismo del siglo XXI".

18 Kirchner había sido derrotado en primera vuelta por Carlos S. Menem, quien había obtenido el 24, 41 $\%$ de los votos. La renuncia de este último a enfrentar al primero en un ballotage fue lo que condujo a Kirchner a la presidencia de la nación.
} 
presidencial y dar respuesta a aquellas demandas de orden (Cavarozzi, 2011; Sidicaro, 2011). ${ }^{19}$

Esta figura relativamente desconocida a nivel nacional -que había iniciado su trayectoria política en los años 70 militando en la Juventud Peronista mientras cursaba sus estudios universitarios en la ciudad de La Plata y, más tarde, había llegado a ser intendente de Río Gallegos, gobernador de la provincia de Santa Cruz y jefe de su pequeño Partido Justicialista- se lanzó a la carrera presidencial encabezando la lista del Frente para la Victoria (FPV) -coalición política creada con esos fines- bajo el auspicio de Eduardo Duhalde, el referente justicialista más fuerte del período encargado de recomponer la estabilidad institucional durante el 2002.

Ya en el poder y una vez normalizada la macroeconomía y consolidado su liderazgo político, Kirchner insistiría en que el futuro de la Argentina resultaba viable solo si el Estado -principal instrumento para la recuperación económica, social y política- lograba recobrar su poder y ponerse al servicio del "pueblo", el cual era exhibido como sujeto soberano ya no en oposición a la clase política, sino en alianza con ella (Muñoz y Retamozo, 2008; Panizza, 2008; Paramio, 2008).

A esta retórica de corte nacional-popular heredera del peronismo que el mandatario había empezado a delinear tempranamente, se irían incorporando otros tópicos como la democratización de los derechos humanos, la memoria del pasado reciente y la justicia transicional en tanto piezas de un discurso que reivindicaba la memoria setentista (Svampa, 2007; Montero, 2011; Retamozo, 2013). Cuatro años después, Kirchner no solo había logrado consolidarse como un actor político clave, sino también sentar las bases para un segundo período presidencial, esta vez, protagonizado por su esposa, Cristina Fernández de Kirchner.

\section{Bolivia}

\footnotetext{
19 En este sentido, no llama la atención que la cuestión del orden se viera recogida en los slogans elegidos para la campaña presidencial: "Por un país en serio" o "Un país normal es posible”. Por otro lado, las declaraciones de Kirchner realizadas el 27 de abril de 2003, horas después del cierre de los comicios cuando ya se sabía que habría una segunda vuelta electoral, permiten observar de qué manera el candidato había interpretado las demandas vinculadas al orden y la normalidad: "Está claro que la mayoría de los argentinos han votado por un cambio, la mayoría de los argentinos votaron por combatir la corrupción, la mayoría de los argentinos votaron por la inclusión social, la mayoría de los argentinos votaron por el trabajo, la mayoría de los argentinos votaron porque la clase media recupere la movilidad ascendente, la mayoría de los argentinos votaron porque la clase trabajadora vuelva a resurgir en la patria (...)". Disponible en: https://www.youtube.com/watch?v=n_34QbXIQso
} 
Los albores del nuevo siglo encontraron una Bolivia asediada por viejas y nuevas tensiones que pusieron en jaque la legitimidad del paradigma neoliberal: la oposición entre neoliberalismo y nacionalismo en materia de propiedad y manejo de los recursos naturales, la discordancia regional, étnica y cultural entre el oriente y el occidente del país y la tensión entre una política tradicional asentada en el sistema de partidos y la reemergencia de formas de acción colectiva expresadas en movimientos sociales y organizaciones corporativas (Mayorga, 2006).

Puntualmente, fueron los sucesivos enfrentamientos con el Estado en la región cochabambina del Chapare por la erradicación del cultivo de hoja de coca a lo largo de los 90 y principios del 2000 los que terminaron situando a Evo Morales en el centro de la política nacional (Stefanoni, 2004; 2015b). Éste -que había nacido en una familia humilde de origen aymara en una pequeña localidad del departamento de Oruro- migró a aquella región en la década del 80 , dando inicio a su carrera sindical en la Confederación Sindical Única de Trabajadores Campesinos de Bolivia (CSUTCB) y volviéndose, rápidamente, líder del movimiento cocacolero.

A medida que el ciclo de protestas antiliberales se profundizaba y el Movimiento al Socialismo-Instrumento Político por la Soberanía de los Pueblos (MAS-IPSP) ${ }^{20}$ comenzaba a afirmar su peso electoral, aquel movimiento indígena-campesino nacido en el ámbito rural empezaría a extender sus redes hacia las zonas urbanas, especialmente, el occidente andino del país, hasta lograr ampliar sus bases de apoyo e interpelar también a las clases medias y bajas del mundo urbano, lo cual posibilitó que en diciembre del 2005 el MAS se impusiera en las urnas con una inédita victoria electoral que le reportó un 53,7\% de los votos (Do Alto, 2011).

Recuperando una retórica nacionalista revolucionaria -heredera de experiencias previas y estructurada en la oposición nación/anti-nación, anti-imperialismo y demanda

\footnotetext{
20 Luego de varios intentos por conformar un partido campesino, Morales creó en 1998 el Instrumento Político por la Soberanía de los Pueblos (IPSP), una suerte de brazo político que encauzara los intereses de la organización sindical a nivel nacional. Sin embargo, para poder presentarse en las elecciones municipales de 1999, Morales debió conseguir la sigla de un socio de Izquierda Unida, el Movimiento al Socialismo (MAS). Como explica Do Alto, "El MAS-U era un desprendimiento de Falange Socialista Boliviana que fue girando hacia la izquierda bajo el liderazgo de David Añez Pedraza. La 'u' (en homenaje al líder fascista Óscar Únzaga de la Vega) fue retirada en un congreso partidario y el nombre oficial quedó establecido como Movimiento al Socialismo-Instrumento Político por la Soberanía de los Pueblos (MAS-IPSP)" (2011:100).
} 
de nacionalizaciones- aunque apelando también al indianismo -este nuevo nacionalismo ya no era conjugado por las Fuerzas Armadas o las clases medias urbanas ni el sujeto político era la clase obrera, sino que en el centro de esta articulación debían situarse las masas indígenas y campesinas-, la denominada RDC se propondría, una vez en el poder, refundar el país en tanto consideraba que la independencia había derivado en formas de colonialismo interno y ausencia de soberanía, anulando la posibilidad de construir un auténtico Estado nacional (Stefanoni, 2006; 2015b).

\section{Ecuador}

La convulsionada década de los noventa culminó en Ecuador con una aguda crisis económica, financiera, política y social, la cual -además de afectar la hegemonía de los poderes fácticos y el prestigio de los movimientos sociales- habilitó un terreno propicio para la emergencia de un nuevo movimiento político, Alianza PAIS (AP) -Patria Altiva i Soberana-, organizado alrededor de la figura de Rafael Correa Delgado. Nacido en un hogar guayaquileño de clase media-baja y hondas convicciones católicas, con un pasado de misionero salesiano en las sierras ecuatorianas y luego de un recorrido académico por la Universidad de Illinois y la Universidad Católica de Lovaina, Correa dispuso su retorno definitivo a la ciudad de Quito en medio de otra crisis institucional que profundizaba aún más la inestabilidad del país.

De esta manera, 2005 fue el año que marcó una ruptura decisiva en la vida del académico al ser designado Ministro de Economía y Finanzas por el entonces vicepresidente Alfredo Palacio, quien asumió el gobierno después de que el Parlamento destituyera al presidente Lucio Gutiérrez como consecuencia de una gran movilización popular protagonizada por el movimiento indígena. El breve período de tiempo que Correa estuvo al frente de esa cartera de Estado bastó para exhibir una actitud beligerante en contra de los organismos de crédito internacionales y para delinear una retórica contraria a la ortodoxia neoliberal y la política tradicional, además de hacer ostensible sus cualidades de liderazgo y carisma personal.

Tras su ruptura con el gobierno y su consecuente alejamiento, emprendió la actividad como consultor independiente y, en febrero de 2006, junto a un grupo de 
académicos e intelectuales que se propusieron construir una amplia alianza de izquierda, fundó AP, con el cual se lanzó a la carrera presidencial triunfando en segunda vuelta el 26 de noviembre de 2006 con el 56, 67\% de los votos (Hernández y Buendía, 2011).

La principal estrategia discursiva puesta en marcha durante aquella campaña electoral consistió en confrontar con las élites y los partidos políticos tradicionales al tiempo que procuró diluir las diferencias entre los distintos actores sociales y unificar un electorado históricamente atravesado por demandas juzgadas -por este nuevo actor político- como "particularistas" y "corporativistas".

De ahí la prescindencia del sustento en los partidos políticos y la apelación a un discurso "ciudadano" que habría contribuido al apoyo masivo a Correa en las reiteradas elecciones y consultas populares, así como al pretendido proceso de “descorporativización" del Estado y la sociedad ecuatoriana puesto en marcha una vez en el poder (Ramírez Gallegos, 2010; Ospina Peralta, 2011; Lalander y Ospina Peralta, 2012).

En resumen, el conjunto de estallidos sociales, políticos y económicos producidos en América del Sur a finales del siglo XX y principios del siglo XXI condujeron al quiebre del consenso neoliberal y a significativas transformaciones que "no se limitaron a alternancias en el gobierno, sino que abarcaron dimensiones más profundas, vinculadas con las maneras de hacer política en las sociedades de la región" (Cavarozzi, 2011: 14). La instauración de nuevos gobiernos que vinieron a sustituir a aquellos otros estrechamente asociados a las reformas neoliberales fue, en efecto, expresión de ello.

Ahora bien, frente a ciertas miradas estereotipadas, antagónicas o concluyentes que a menudo circularon sobre este momento particular de la historia reciente sudamericana, este escrito persigue, ante todo, el desafío de

rescatar los múltiples y heterogéneos vasos comunicantes del espíritu de [esa] época, no para negar las contraposiciones y distancias heredadas, sino para recuperar el ambiente menos susceptible de esquematismos en el que los diferentes individuos tomaban sus decisiones, expresaban sus discursos y practicaban sus actos (...) excepcionales (Bisso, 2009: 11). 
Casualmente, estas experiencias de gobierno -atravesadas cada una de ellas por rasgos y lógicas particulares- fueron a quienes les tocó afrontar las celebraciones de un nuevo centenario del inicio de los procesos de "independencia", ocasiones que, en última instancia y al calor de ciertas fluctuaciones políticas, serían aprovechadas para revisar las representaciones en torno a la identidad nacional y desplegar sus concepciones de Estado, nación y sociedad.

Estos escenarios festivos serán, entonces, el observatorio elegido para, justamente, analizar de qué manera coexistieron, al interior de estos gobiernos, una multiplicidad de prácticas y discursos -por momentos, ambiguos e, incluso, contrapuestos-, cuyo análisis posibilitará dar cuenta del carácter más bien complejo, flotante y permeable de las identidades y los valores que aquellos movimientos o actores políticos parecieron encarnar.

\section{Los regímenes conmemorativos del bicentenario. Orígenes, fundamentos y} primeras aproximaciones

¿Cuándo comenzó la proyección de las celebraciones bicentenarias? ¿Quiénes fueron los actores que las impulsaron? ¿Cuáles fueron sus pilares y dinámicas institucionales? ¿Y sus objetivos o propósitos originales? ¿Bajo qué condiciones y de qué manera se fueron produciendo dichos acontecimientos? A fin de responder a estos interrogantes, se propone, a continuación, un recorrido que permita dar cuenta de los distintos contextos y procesos políticos e institucionales que -con vaivenes, obstáculos e imprevistos- fueron dando forma a los regímenes conmemorativos de los bicentenarios de "independencia" en cada uno de estos países.

En este sentido, el primer movimiento en torno a la cuestión bicentenaria en América del Sur se remonta al cambio de siglo cuando el 9 de diciembre de 1999, esto es, durante el último día de la presidencia de Menem, se emitía un primer decreto 
dirigido a crear la "Comisión del Bicentenario de la Revolución de Mayo 1810-2010".

Justo al inicio del texto, éste establecía:

Que la orientación cívica de esta celebración deberá ser compartida con todos los estamentos de la sociedad civil, para que la rememoración de las históricas jornadas de la Revolución se integre como herencia común, lo que permitirá —con una programación concertada - lograr el mayor consenso al culminar la celebración en el año $2010 .{ }^{21}$

De esta forma, el entonces presidente de la nación argentina se despedía de sus funciones sentando los primeros lineamientos oficiales del -en aquel momento- todavía lejano festejo bicentenario. En ese horizonte, la búsqueda del "mayor consenso" y la “consolidación definitiva de la unidad nacional en el espíritu republicano que iniciara nuestra etapa fundacional" 22 aparecían como las metas fundamentales a alcanzar una vez concluida la efeméride en cuestión. ${ }^{23}$

Tres años y medio debieron pasar para que otro de los países siguiera los pasos de Argentina. En esta ocasión, fue el mandatario boliviano Gonzalo Sánchez de Losada quien, dos meses antes de abandonar tempranamente su cargo y en medio de un creciente clima de conflictividad social, emitía una ley a partir de la cual se instituía el

\footnotetext{
${ }^{21}$ Decreto $\mathrm{N}^{\circ} 1561$ del 9 de diciembre de1999. Disponible en: http://www.saij.gob.ar/1561-nacionalcreacion-comision-bicentenario-revolucion-mayo-1810-2010dn19990001561-1999-12-09/123456789-0abc-165-1000-9991 soterced?\&o=15\&f=Total\%7CFecha/ 1999\%5B20\%2C1\%5D\%7CEstado\%20de\%20Vigencia/

Vigente $\% 2 \mathrm{C} \% 20$ de $\% 20$ alcance $\% 20$ general\%7CTema $\% 5 \mathrm{~B} 5 \% 2 \mathrm{C} 1 \% 5 \mathrm{D} \% 7 \mathrm{COrganismo} \% 5 \mathrm{~B} 5 \% 2 \mathrm{C} 1 \% 5 \mathrm{D}$ \%7CAutor $\% 5 \mathrm{~B} 5 \% 2 \mathrm{C} 1 \% 5 \mathrm{D} \% 7 \mathrm{CJurisdicci} \% \mathrm{~F} 3 \mathrm{n} /$ Nacional $\% 7 \mathrm{CTribunal} \% 5 \mathrm{~B} 5 \% 2 \mathrm{C} 1 \% 5 \mathrm{D} \% 7 \mathrm{CPublicaci} \% \mathrm{~F} 3 \mathrm{n} \% 5 \mathrm{~B} 5 \% 2 \mathrm{C} 1 \% 5 \mathrm{D} \% 7 \mathrm{CColecci} \% \mathrm{~F} 3 \mathrm{n} \% 20$ tem \%E1tica\%5B5\%2C1\%5D\%7CTipo\%20de\%20Documento/Legislaci\%F3n/Decreto\&t $=180$

22 Ibídem.
}

23 Cabe recordar que estas búsquedas fueron una constante en los usos del pasado efectuados, desde sus inicios, por el menemismo. En efecto, Jefrey Shumway (2010) analiza la repatriación de los restos de Juan Manuel de Rosas que tuvo lugar el $1^{\circ}$ de octubre de 1989, interpretándola como una estrategia política del recién asumido presidente dirigida a consolidar un discurso de pacificación, reconciliación y unión nacional tras dos décadas de agudos conflictos sociales, políticos y económicos. Fue, justamente, días después de dicho acontecimiento que Menem decretó los primeros indultos a civiles y militares envueltos en la última dictadura militar.

A esto se sumaría, tres años después, el lanzamiento del billete de 20 pesos con la figura en primer plano de Rosas junto a "Manuelita" Rosas y en el reverso, una imagen de La Vuelta de Obligado.

Según Shumway, fue a partir de la reivindicación de la figura de Rosas que el nuevo gobierno esperaba, entonces, reconciliar historias, memorias y posturas históricamente enfrentadas -recientes pero también lejanas- a fin de propiciar, en palabras del entonces mandatario, el "reencuentro entre todos los argentinos". 
“Comité Nacional de Conmemoración del Bicentenario del Primer Grito Libertario en América del 25 de Mayo de 1809”. A diferencia del caso anterior, entre los objetivos allí establecidos no se incluían referencias a la necesidad de fortalecer el ser y/o la unidad nacional, sino que éstos consistían en:

1. Difundir, nacional e internacionalmente, el acontecimiento histórico acaecido el 15 [sic] de Mayo de 1809, en Charcas.

2. Generar eventos académicos, culturales y políticos que otorguen al Bicentenario del Primer Grito Libertario en América, el realce que le corresponde.

3. Promover la profundización de los procesos de integración entre los países sudamericanos.

4. Resaltar el papel protagónico que los hombres y mujeres oriundos de Bolivia, tuvieron en la emancipación del continente. ${ }^{24}$

De modo que el interés, en este caso, se hallaba más bien en acentuar el carácter precursor de la Revolución de Chuquisaca "en la emancipación del continente" y, en cuanto tal, su potencial para favorecer la integración sudamericana. La cuestión bicentenaria en Bolivia surgía, entonces, asociada a una sola fecha -de carácter local pero elevada a festividad nacional-, descartándose -en un primer momento- la posibilidad de enlazar a ésta la conmemoración de los doscientos años de otras revoluciones como la de La Paz, Cochabamba o Potosí. A diferencia de su precedente argentino, este decreto se mantendría, al menos formalmente, como el marco normativo oficial de la celebración organizada por el gobierno del MAS casi seis años después.

El 25 de agosto de 2004 el sucesor de Sánchez de Losada, Carlos D. Mesa Gisbert, retomaba los preparativos del festejo al aprobar -mediante la Ley $\mathrm{N}^{\circ} 2804-\mathrm{el}$ "Marco Estratégico del Plan Quinquenal del Bicentenario del primer Grito Libertario de América de 25 mayo de 1809”, cuyos objetivos eran:

I. Promover la calidad de Capital de la República, a la ciudad de Sucre.

II. Rescatar el carácter histórico y arquitectónico continental de Sucre.

\footnotetext{
${ }^{24}$ Ley N ${ }^{\circ} 2501$ del 5 de agosto de 2003. Disponible en: http://anterior.gacetaoficialdebolivia.gob.bo/
} normas/verGratis_gob/17873 
III. Convertir a la Capital de la República en el principal centro cultural, turístico y de convenciones del país.

IV. Implementar en Sucre el Sistema Integral de Educación.

V. Ensayar en Sucre la implementación del Sistema Integral de Salud.

VI. Asegurar la concreción de Obras de infraestructura Estratégica para cumplir los objetivos anteriormente mencionados. ${ }^{25}$

Por consiguiente, el arribo del bicentenario de la Revolución de Chuquisaca se convertía en una excusa para valorizar la ciudad de Sucre en la escena local, nacional e internacional y disputar su "capitalía plena", esto es, el retorno a ésta de la sede del Poder Ejecutivo y Legislativo, algo que tiempo después -durante la Asamblea Constituyente $(\mathrm{AC})^{26}$ derivaría en un agudo conflicto con el gobierno del MAS, afectando los planes de la celebración bicentenaria.

En contraposición a los casos boliviano y argentino -donde las fechas a ser celebradas se puntualizaron de manera inmediata en normas con rango de ley-, en Venezuela el llamamiento a la acción conmemorativa realizada por Chávez se tornaría un asunto bastante más impreciso e inestable. En efecto, la determinación de las fechas a ser incluidas dentro de un posible "ciclo bicentenario" comenzó a ser discutida el 5 de julio de 2005, es decir, durante el $194^{\circ}$ aniversario de la firma del Acta de la Declaración de Independencia, cuando el ex presidente anunció: “el 15 de agosto de este 2005, conmemoraremos doscientos años y con ello daremos inicio a un ciclo bicentenario, pudiéramos 1lamarlo: El Supremo Ciclo Bicentenario Bolivariano”.27

${ }^{25}$ Ley $\mathrm{N}^{\circ} 2804$ del 25 de agosto de 2004. Disponible en: http://www.derechoteca.com/gacetabolivia/ ley-2804-del-25-agosto-2004/

\footnotetext{
${ }^{26}$ Fue luego de la crisis de octubre de 2003 y de la caída del gobierno entonces vigente que la demanda de una AC se volvió un elemento fundamental de la denominada "Agenda de Octubre". La AC se vio, finalmente, instalada el 6 de agosto de 2006 en la ciudad de Sucre con el fin de redactar una nueva constitución, la cual fue aprobada -en medio de disturbios, protestas y enfrentamientos- el 10 de diciembre de 2007. Luego de ser modificada por el Congreso Nacional a finales del 2008, el referéndum constitucional del 25 de enero de 2009 aprobó la nueva Carta Magna con un 61,43\% de votos a su favor.

27 Discurso pronunciado por Hugo Chávez Frías en Caracas, 5 de julio de 2005. Disponible en: https:// www.aporrea.org/actualidad/a15192.html
} 
Tomando como acontecimiento inaugural los doscientos años del juramento realizado por Simón Bolívar en el Monte Sacro (1805), ${ }^{28}$ Chávez parecía decidido a instaurar un largo y abarrotado período de celebraciones bicentenarias que se extendería hasta el 2030 y comprendería nada más ni nada menos que a los bicentenarios del desembarco de la primera expedición de Francisco de Miranda (1806), del establecimiento de la "Suprema Junta Conservadora de los Derechos de Fernando VII" (1810), de la firma del Acta de la Declaración de Independencia (1811), del Congreso de Angostura (1819), de la Batalla de Carabobo (1821), de la Batalla Naval del Lago de Maracaibo (1823) y de la muerte de Simón Bolívar (1830).

Paralelamente, Néstor Kirchner retomaba en agosto de ese mismo año las riendas del bicentenario de la Revolución de Mayo emitiendo un nuevo decreto presidencial que creaba, en el ámbito de la Jefatura de Gabinete de Ministros, el "Comité Permanente del Bicentenario" encargado de establecer los lineamientos generales de lo que se denominó el "Plan de Acción del Bicentenario", esto es, las metas, obras y actividades culturales que serían desarrolladas -a nivel nacional, provincial y municipal-durante la efeméride en cuestión. Esta normativa -que, antes que nada, dejaba sin efecto aquella otra firmada aproximadamente seis años atrás por Menem-29 reclamaba la necesidad de otorgarle a la mencionada fecha "una significación y una relevancia muy especiales" dado que el país venía de "atravesar una de las crisis más profundas de su historia". ${ }^{30}$

Aunque revestido de un lenguaje que buscaba romper con la herencia liberalconservadora que envolvía a su antecedente (Molinaro, 2017), este decreto subrayaba en línea con aquél- la importancia de aprovechar los doscientos años de Mayo para reforzar, de nuevo, la unidad nacional. Así pues, la revolución rioplatense constituía una ocasión favorable "para afirmar los lazos nacionales, democráticos y de respeto mutuo

\footnotetext{
${ }^{28}$ La importancia otorgada al 15 de agosto y su consideración en tanto fecha inaugural de un posible "Supremo Ciclo Bicentenario" se comprende si tenemos en cuenta que fue, justamente inspirado en ese juramento, que surgió el llamado "juramento bolivariano", esto es, el compromiso o voto que debían efectuar clandestinamente todos los miembros del MBR 200 incorporados antes del primer golpe de 1992.

${ }^{29}$ En el artículo $1^{\circ}$ se establecía: "Déjase sin efecto el Decreto $\mathrm{N}^{\circ} 1561$ de fecha 9 de diciembre de 1999 y todas las disposiciones y medidas que se hayan dictado en su marco". Decreto $N^{\circ} 1016$ del 25 de agosto de 2005. Disponible en: http://servicios.infoleg.gob.ar/infolegInternet/ verNorma.do;jsessionid $=520 \mathrm{~B} 0152 \mathrm{DAF} 27708 \mathrm{E} 7 \mathrm{E} 333174 \mathrm{~F} 0 \mathrm{~F} 4 \mathrm{~F} 12 ? \mathrm{id}=109126$
}

30 Ibídem. 
que deben unir a todos los habitantes del suelo argentino en la conformación de una sociedad integrada e incluyente", lo cual conllevaba, a su vez, otro requisito, el de "crear conciencia en la población acerca de la extraordinaria importancia que reviste confluir en un proyecto común, sin desmedro alguno de las diferencias particulares y de la diversidad cultural existentes". 31

Hacia mediados del 2006, dos fechas de importancia se acercaban tanto para el gobierno argentino como para el venezolano. La primera de ellas consistió en el bicentenario de las Invasiones Inglesas al Virreinato del Río de La Plata, celebración que el Poder Ejecutivo nacional delegó en manos del entonces gobernador oficialista de la provincia de Buenos Aires, Felipe Solá. Si bien este episodio había sido históricamente rememorado como la "heroica reconquista de la Ciudad de Buenos Aires", ${ }^{32}$ que su organización recayera sobre la gobernación de la provincia podía relacionarse al hecho de que dos meses antes de iniciarse las primeras gestiones en torno a dicho acontecimiento tuvo lugar la destitución -juicio político mediante- del entonces -también oficialista- Jefe de Gobierno de la Ciudad de Buenos Aires, Aníbal Ibarra.

En consecuencia, Solá fue el encargado de crear -por medio del Decreto $\mathrm{N}^{\circ} 1129$ del 16 de mayo de 2006- la "Comisión Provincial del Bicentenario", 33 la cual tenía

como función celebrar en el año en curso, el Homenaje a la Reconquista de Buenos Aires, y la participación de la Provincia, hacia la conmemoración del Bicentenario de la Patria en el año 2010;

Que en razón de ello, la Provincia concurre con la Nación en la creación de un estado de conciencia popular tendiente a dar relieve histórico a las celebraciones del Segundo Centenario de la Revolución de Mayo del año 1810;

\footnotetext{
31 Ibídem.

32 Decreto No 1129 del 16 de mayo de 2006. Resaltado mío. Disponible en: http://www.gob.gba.gov.ar/ $\underline{\text { legislacion/legislacion/06-1129.html }}$

33 Cabe señalar que, "por razones de correcta técnica legislativa" esta norma derogó el decreto anterior $\mathrm{N}^{\circ} 3.110$ del 20 de diciembre de 2005, cuya finalidad era la misma. Sin embargo, a diferencia del decreto derogado, su sucesor (además de convocar a formar parte de la Comisión a las autoridades del Ejército Argentino y al Arzobispado de Mercedes-Luján) invitaba también a "a los ex-combatientes de las Islas Malvinas con residencia en el Territorio Provincial".
} 
Que en tránsito hacia el año 2010 -Bicentenario del nacimiento de la Patria- se comienza a reactivar de modo creciente la verdadera recuperación de la memoria y la actualización de un proyecto verdadero y definitivamente nacional;

Que en ese sentido, se menciona a las invasiones inglesas y la reconquista de la Ciudad de Buenos Aires como precedentes del pronunciamiento de mayo de 1810 $(\ldots)^{34}$

De esta manera, se establecía -aunque sin proclamar un "ciclo bicentenario" al estilo venezolano- a las Invasiones Inglesas como el hecho precursor del "nacimiento de la Patria" y a su conmemoración bicentenaria como un antecedente primordial para los doscientos años de Mayo capaz de contribuir al armado de un "verdadero" proyecto nacional y a la "conscientización" del pueblo en torno a su importancia. Asimismo, este suceso se vería directamente enlazado a otro episodio clave de la historia reciente nacional. En efecto, para Ernesto Jauretche, secretario general de la Comisión, "los acontecimientos de 1806 fueron una especie de 2001, el protagonismo popular con una clase política superada por las circunstancias, una rebelión social que permite defender la ciudad y formar las primeras milicias". 35

La segunda fecha en cuestión se trató del bicentenario del desembarco de la primera expedición de Francisco de Miranda a La Vela de Coro. En homenaje a este episodio fue que el gobierno de la RB decidió bautizar a la campaña electoral del 2006 como "Batalla Miranda" (Romero Jiménez, 2007), a lo largo de la cual Chávez

\footnotetext{
34 Decreto $N^{\circ} 1129$ del 16 de mayo de 2006. Disponible en: http://www.gob.gba.gov.ar/legislacion/ legislacion/06-1129.html

35 La Nación, 11 de junio de 2006. Disponible en: https://www.lanacion.com.ar/813312-invasionesinglesas-revisionismo-y-politica

Cabe destacar que la exaltación de las Invasiones Inglesas como acontecimiento precursor de la Revolución de Mayo, así como el otorgamiento de una lectura ideológica no resultan operaciones novedosas. En efecto, como lo ilustran Javier Kraselsky y Andrés Bisso en su estudio sobre la utilización política de las Invasiones Inglesas por parte de dos actores políticos distantes en el tiempo (los patriotas contemporáneos a dicho acontecimiento y los nacionalistas del período de entreguerras), "las Invasiones Inglesas se volvieron un referente importante, tanto en la historiografía argentina (...) como en las lecturas políticas posteriores, que buscaron extraer de ellas ciertas lecciones como nación" (2010: 62-63).
} 
anunciaría el tránsito hacia el "socialismo del siglo XXI" y la creación de un partido único que reuniera a todas las fuerzas políticas y sociales favorables a su gestión. ${ }^{36}$

A fin de avanzar con los preparativos de dicha efeméride, el mandatario había emitido un decreto en marzo de 2005 que declaraba "año mirandino el período comprendido entre el 3 de agosto del presente año, hasta el 3 de agosto de 2006", creaba "la Misión Precursora en honor a tan insigne prócer" con el objetivo de "favorecer la elevación del papel de la historia en la cultura nacional" y, finalmente, establecía "con carácter temporal la Comisión Presidencial Conmemorativa del Año mirandino".37

Si bien esta norma había sido redactada algunos meses antes de que el mandatario proclamara el inicio del "Supremo Ciclo Bicentenario Bolivariano" y pese a que la idea de un ciclo 2010-2030 reaparecería nuevamente en algunos discursos presidenciales al aproximarse el bicentenario del 19 de abril, 38 durante el acto conmemorativo de agosto de 2006 Chávez parecía proponer una reformulación en torno a cómo organizar, concebir y emparentar los dos primeros bicentenarios patrios a su cargo:

Llegó la era bicentenaria 2006 o mejor dicho 2005-2006, los dos gigantes que fueron Bolívar y Miranda dejaron su huella aquellos años, uno concluía o estaba concluyendo su camino, el otro comenzaba pero al final aquellos dos caminos el de Miranda y el de Bolívar se unieron en uno solo y se proyectaron y aquí estamos

\footnotetext{
36 De igual modo, fue en las vísperas de esta celebración que finalmente el gobierno de la RB presentó el nuevo Escudo de Armas y la nueva Bandera Nacional. "Chávez hizo pública su propuesta de cambiar la bandera y el escudo en su programa de televisión Aló Presidente, transmitido en vivo el 20 de noviembre del 2005. En relación con la bandera su planteamiento fue que debía incluirse una octava estrella [decretada por Bolívar el 20 de noviembre del 1817 con el objetivo de representar a la provincia de Guayana que había sido liberada a finales de 1816 del dominio español] y respecto al escudo su proposición fue que se modificara la dirección del caballo para que estuviese galopando hacia la izquierda (...) el 12 de marzo de 2006 (...) Chávez izó la nueva bandera, la ocasión fue oportuna para dirigirse al país en cadena nacional y reiterar la significación que tenían los cambios introducidos en los símbolos patrios ya que, al reunirse el tricolor traído por Miranda y la octava estrella decretada por el Libertador, se había recuperado 'el espíritu del proyecto libertario de Simón Bolívar y Francisco de Miranda'. La octava estrella, representaba 'la victoria y el futuro'; mientras que el caballo libre, brioso trotando hacia la izquierda representaba 'el retorno de Bolívar' (Quintero, 2018: sin pp.)
}

37 Decreto No 3.544/2005. Disponible en: http://www.todochavez.gob.ve/todochavez/3549-intervenciondel-comandante-presidente-hugo-chavez-durante-acto-con-motivo-del-255-aniversario-del-nacimientodel-generalisimo-francisco-de-miranda-y-juramentacion-de-la-comision-presidencial-conmemorativa-delano-mirandino

38 En febrero de 2010, durante un acto en homenaje a Ezequiel Zamora, el entonces mandatario afirmaba: "Este año 2010 se inicia el ciclo bicentenario, de la era bicentenaria del 2010 al 2030 hemos dicho, 20 años que comienzan ahora de dura batalla para consolidar la Revolución". Discurso pronunciado por Hugo Chávez Frías en Caracas, 20 de febrero de 2010. Disponible en: http://www.todochavez.gob.ve/ todochavez/488-intervencion-del-comandante-presidente-hugo-chavez-durante-acto-de-homenaje-algeneral-del-pueblo-soberano-ezequiel-zamora-y-promulgacion-de-la-ley-del-consejo-federal-de-gobierno 
hoy 200 años después (...) estamos aquí para ahora hacer vivir a Miranda y hacer vivir a Bolívar en la gran victoria de la Revolución Bolivariana y la unidad suramericana, 200 años después. 39

Es así que la idea original de un gran continuo de festejos bicentenarios que abarcara un período de 25 años, hacia el 2006 parecía disolverse y fragmentarse en intervalos conmemorativos más reducidos, quedando en suspenso cuáles iban a ser las fechas patrias elegidas para celebrar el bicentenario de "independencia" venezolano.

A estas alturas, el único país que no contaba con ningún marco normativo ni planteamiento relativos a la organización de su celebración bicentenaria era Ecuador. 40 Sin embargo, esa situación se vio corregida casi un año después cuando, en agosto de 2007 en pleno proceso de convocatoria a la AC, el recientemente elegido presidente, Rafael Correa Delgado, emitía un decreto que declaraba como

\begin{abstract}
“Años de Promoción Nacional" los de 2007 y 2008 y años de "Recordación Nacional del Bicentenario" los de 2009 a 2012, para exaltar la celebración de la Independencia ecuatoriana y promover el civismo y el amor a la Patria con la recordación y reflexión del significado histórico de estos acontecimientos. ${ }^{41}$
\end{abstract}

La “Comisión Nacional Permanente de Conmemoraciones Cívicas”, creada en 1982,42 aparecía como el organismo encargado de coordinar el elenco de actividades oficiales destinadas a "informar y fomentar en la ciudadanía ecuatoriana el patriotismo, el civismo, la solidaridad y la unidad en la diversidad". ${ }^{43}$ De esta manera, el gobierno de la $\mathrm{RC}$ daba sus primeros pasos hacia la organización de un acontecimiento que era

\footnotetext{
39 Discurso pronunciado por Hugo Chávez Frías en La Vela de Coro, 3 de agosto de 2006. Disponible en: http://www.todochavez.gob.ve/todochavez/3212-intervencion-del-comandante-presidente-hugo-chavezen-la-conmemoracion-del-bicentenario-de-la-llegada-de-francisco-de-miranda-a-la-vela-de-coro-y-diade-la-armada

40 Cabe señalar que la intendencia de la ciudad de Quito sí había lanzado hacia el 2004 un plan de gobierno, a nivel municipal, denominado "Quito hacia el Bicentenario", cuyo propósito era alcanzar un desarrollo sustentable de la capital, al igual que su reposicionamiento a nivel nacional e internacional, especialmente, tras la crisis financiera de 1999.

41 Decreto ejecutivo N ${ }^{\circ} 561$ del 17 de agosto de 2007. Disponible en: https://minka.presidencia.gob.ec/ portal/usuarios_externos.jsf

42 Decreto ejecutivo N 441 del 8 de junio de 1982.

43 Ibídem.
} 
presentado no solo como "el inicio de la celebración del Bicentenario de la independencia ecuatoriana", sino también "andina e hispanoamericana". 44

Así las cosas, cada uno de los gobiernos de los cuatro países encaraba los preparativos de sus respectivos festejos bicentenarios de manera aislada hasta que en diciembre de 2007 decidieron -junto con Chile, México, la Organización de Estados Iberoamericanos para la Educación, la Ciencia y la Cultura y la Secretaría General Iberoamericana- dar cauce al llamado "Grupo Bicentenario", 45 a saber, una "instancia multilateral creada con el objetivo de promover y organizar la conmemoración conjunta de los procesos de independencia desarrollados en el continente americano hace 200 años". 46

Este organismo, coordinado por un secretariado pro tempore ejercido por turnos a renovarse cada seis meses, ${ }^{47}$ tenía como propósito organizar y favorecer instancias de reflexión política y académica tanto en el marco de los denominados "Diálogos del Bicentenario" 48 como en sus reuniones formales (siendo el objetivo de éstas últimas dar

\footnotetext{
44 Ibídem.

45 Esta iniciativa, efectivizada con aquella primera reunión de los países miembro originales durante diciembre del 2007 en Santiago de Chile, empezó a concebirse en el marco de la X Cumbre Iberoamericana de Ministros de Cultura el 26 de julio de ese mismo año. Asimismo, cabe agregar que posteriormente, se fueron incorporando Paraguay, Colombia, El Salvador y España. Véanse: https:// www.oei.es/historico/xcic.htm y http://www.bicentenarios.gob.es/GrupoBicentenario/Paginas/ GrupoBicentenario.aspx
}

46 Disponible en: http://www.grupobicentenario.org/quienes-somos/

47 El secretario pro tempore por Bolivia fue el periodista y escritor Alex Aillón Valverde (de diciembre de 2007 a mayo de 2008); por Ecuador, el historiador Juan Paz y Miño (de mayo a septiembre de 2008); por Argentina, si bien no se especifica quién ocupó ese cargo, fue el entonces Secretario de Cultura, José Nun, el referente argentino presente en varias de las reuniones del "Grupo Bicentenario" (de septiembre de 2008 a mayo de 2009); finalmente, en el caso de Venezuela, su mandato no llegó a ponerse en práctica (Krizmanics, 2014).

48 Estos consistieron en exposiciones académicas realizadas por expertos e intelectuales de los países miembros en torno a las temáticas "América Latina y el Bicentenario: la historia entre el pasado y el presente", "Procesos de Independencia: balance de los últimos 200 años, cultura, migración y nuevas formas de integración social” y "Democracia y Buen Gobierno en el mundo actual”. Algunos de sus expositores fueron: por Argentina, José Nun (abogado y politólogo entonces Secretario de Cultura de la Nación), Carlos Moneta (politólogo y docente de la Universidad Nacional Tres de Febrero), Beatriz Carolina Crisorio y Claudio Spiguel (historiadores y docentes de la Universidad de Buenos Aires); por Venezuela, Carmen Bohórquez (filósofa e historiadora funcionaria del Ministerio del Poder Popular para la Cultura), Luis Pellicer (entonces Director del Archivo General de la Nación), Enrique Nóbrega (entonces Director de los Museos Bolivarianos), Lionel Muñoz Paz (historiador nombrado posteriormente Director del Instituto de Estudios Hispanoamericanos de la Universidad Central de Venezuela) y Arístides Medina (historiador entonces Presidente del Centro Nacional de Historia); por Bolivia, Javier Mendoza Pizarro (psicólogo e historiador); por Ecuador, Germán Rodas (historiador de la Universidad Andina Simón Bolívar) y Juan Paz y Miño (historiador de la Pontificia Universidad Católica del Ecuador). 
a conocer la evolución de las agendas conmemorativas delineadas por cada comisión nacional y trazar proyectos editoriales y actividades culturales comunes de carácter masivo).

Ahora bien, lo que se esperaba que funcionara como una instancia pacífica de integración latinoamericana durante los preparativos y ejecución de los festejos bicentenarios se volvería un asunto más complejo tras la propuesta, realizada por el gobierno venezolano el 25 de junio de 2009, de crear el "Grupo ALBA para la Conmemoración del Bicentenario del Inicio de la Revolución de Independencia en Nuestra América”, 49 lo cual sacaba a relucir las diferencias políticas e ideológicas entre algunos de los países miembros del "Grupo Bicentenario".

En efecto, la historiadora y filósofa venezolana Carmen Bohórquez -involucrada en la organización de la celebración bicentenaria de Venezuela- argumentaba:

\begin{abstract}
Existe un grupo Bicentenario donde hay varios países latinoamericanos representados, indudablemente que allí las diferencias políticas se manifiestan hasta en la manera como se va a celebrar los bicentenarios. Están países con gobiernos que son de derecha, e incluso hay algunos que tienen una visión casi comercial del asunto, que lo ven como algo para turistas o como obtener más ingresos. $\mathrm{Y}$ otros, los que estamos más políticamente implicados en procesos revolucionarios, nosotros lo vemos como la ocasión propicia para profundizar la batalla de ideas (Citado en Krizmanics, 2014).
\end{abstract}

De igual modo, la participación de España dentro del grupo -formalizada en febrero de 2009-, así como su interpretación del proceso de independencia constituyeron otro motivo de disputa. En este sentido, Bohórquez también afirmaba que

\begin{abstract}
España pretende dar vuelta a la historia de tal manera que pueda aparecer como si en realidad hubiera sido la verdadera inspiradora de nuestras independencias. Ya lo hizo con la celebración del V Centenario del Descubrimiento de América en 1992 y lo repite ahora (...) España ha logrado participar y financiar buena parte de las actividades previstas en América Latina para el bicentenario de las independencias, incluyendo en ellos el de la Constitución de Cádiz, como si todo fuera el mismo
\end{abstract}

\footnotetext{
49 Para un análisis de las diferencias entre el Grupo Bicentenario y el constituido por los miembros del ALBA, véase Krizmanics (2014).
} 
proceso, un mismo fenómeno revolucionario paralelo (...) se reivindica como puente de América Latina con Europa, y se siente con derecho y autoridad para tutelar a nuestros países, sin reconocer que son pueblos maduros, que no necesitan intermediarios para hacerse oír y valer. En el pasado de nuestro continente, lamentablemente, ha habido países que buscaban ese tutelaje, como otros buscaban o buscan aún hoy día el de Washington. ${ }^{50}$

Más sutilmente, Juan Paz y Miño, historiador estrechamente ligado a la organización de los festejos en Ecuador, señalaría una vez concluidas las festividades que

el bicentenario era una celebración muy propia de América Latina. Ese criterio fue compartido por los representantes de Bolivia, Chile y Venezuela, de manera que, con esa visión de conjunto, se arribó al acuerdo de no crear el "Comité Iberoamericano", sino únicamente el Grupo Bicentenario; pero, además, España adoptó, oficialmente, un concepto diplomático mucho más preciso, pues acordó "acompañar" a los latinoamericanos en sus festejos por el Bicentenario.

Más allá del hecho, puede advertirse que en este otro lado del Atlántico, movilizábamos dos conceptos de fondo: de una parte, no nos identificamos como "Iberoamérica" ni como "Hispanoamérica", sino como América Latina. Se podrá decir que el término no se ajusta a la realidad y que es equívoco. No nos ha importado, ya que hemos llegado a convertirlo en el concepto que nos identifica mejor y por eso decimos ser latinoamericanos y pertenecer a Nuestra América Latina (Paz y Miño, 2014).

De esta forma, la sugerencia de España de instituir una comisión multilateral para los bicentenarios iberoamericanos fue rápidamente desestimada por varios de los países miembros del "Grupo Bicentenario", quienes rechazaron los intentos por parte de 
aquella de intervenir activamente en la organización de los festejos de sus ex “colonias" (Caicedo, 2010). 51

Sin embargo y pese a estas tentativas de articulación supranacional de las celebraciones bicentenarias -que, o bien naufragaron, o bien devinieron meras instancias formales (Malamud, 2011; Krizmanics, 2014)-, cada gobierno continuó la gestión y planificación de estos acontecimientos de manera más bien autónoma, conduciendo ya no a una gran conmemoración conjunta -iberoamericana o continental-, sino a múltiples celebraciones de carácter nacional.

Hacia principios del 2008, nuevas acciones se pusieron en marcha en torno a las cada vez más cercanas- conmemoraciones del bicentenario. En Argentina, Cristina Fernández de Kirchner declaraba, luego de dos meses de mandato y a días de que estallara un intenso conflicto con los sectores agrarios del país, al 2010 como "Año del Bicentenario de la Revolución de Mayo"; para presentarlo a continuación como "una oportunidad única para reflexionar y debatir acerca de la historia y de la identidad (...) como así también para proyectar la construcción colectiva de un proyecto país hacia el futuro, con inclusión social, federal e integrado a la región latinoamericana". 52

Asimismo, creaba -al interior de la Secretaría General de la Presidencia de la Nación a cargo de Oscar Parrilli- la llamada "Secretaría Ejecutiva de la Conmemoración del Bicentenario de la Revolución de Mayo de 1810-2010”, cuyos propósitos consistían en:

1. Diseñar, planificar y ejecutar un programa de actividades y actos conmemorativos a desarrollarse con motivo del Bicentenario de la Revolución de Mayo en la REPUBLICA ARGENTINA.

\footnotetext{
${ }^{51}$ En relación a esta denominación, cabe recordar que los territorios hispanoamericanos técnicamente no constituyeron colonias o factorías, sino que éstos aparecían en La recopilación de leyes de los reinos de las Indias -publicada en Madrid en 1681- como un conjunto de reinos, señoríos, provincias y repúblicas incorporados a la Corona de Castilla y León. Fue justamente este aspecto el cual -en la década del cincuenta a raíz de la publicación de Las indias no eran colonias (1973 [1951]) de Ricardo Levenesirvió de fundamento a la idea de que los reinos americanos eran "autónomos y con privilegios similares a los peninsulares (...) Versión dulcificadota (sic) de la colonización española que tuvo cierto éxito entre cierta parte de una historiografía conservadora que produjo una lectura diferente (...) Frente a la lectura de la independencia como ruptura traumática nació la de la emancipación de evolución lógica y sin traumas" (Chust, 2007: 386).
}

52 Decreto $N^{\circ} 278$ del 18 de febrero de 2008. Disponible en: http://servicios.infoleg.gob.ar/ infolegInternet/anexos/135000-139999/137852/norma.htm 
2. Acordar con los Ministerios y Secretarías de la PRESIDENCIA DE LA NACION, en las cuestiones de sus respectivas competencias, la planificación y ejecución de actividades, obras y programas a desarrollarse.

3. Impulsar y articular en forma conjunta con los gobiernos provinciales y locales actividades conmemorativas.

4. Propiciar y establecer acuerdos y asociaciones con el sector privado y organizaciones de la sociedad civil para el desarrollo de iniciativas conjuntas.

5. Propiciar la emisión de una moneda y de un sello postal conmemorativos en alusión al Bicentenario de la Revolución de Mayo. ${ }^{53}$

El 15 de abril de ese mismo año Correa también emitía un nuevo decreto dirigido a constituir el "Comité Presidencial del Bicentenario", el cual surgía como el organismo responsable de organizar y ejecutar las actividades conmemorativas en Ecuador entre 2009 y 2012 destinadas a:

a) Exaltar el sentimiento patriótico a través de la movilización de voluntades, esfuerzo y recursos de todos los sectores del país;

b) Reforzar la identidad y la unidad nacional, mediante la consolidación de un amplio consenso ciudadano;

c) Proyectar una visión compartida del futuro del país en el ámbito regional e internacional. ${ }^{54}$

Para ello, el "Comité Presidencial del Bicentenario" debía

a) Impulsar la realización de obras de infraestructura, símbolos del Bicentenario, a nivel local y nacional;

b) Fomentar la creatividad ciudadana, tanto en ámbitos institucionales como de la sociedad civil, que permitan la más amplia participación en la comprensión e interpretación del significado del bicentenario;

c) Implementar un programa sostenido de presencia y proyección del país en el ámbito internacional, durante estos cuatro años, con especial énfasis en la celebración del 10 de agosto de 2009;55

\footnotetext{
53 Ibídem.

${ }^{54}$ Decreto Ejecutivo $\mathrm{N}^{\circ} 1023$ del 15 de abril de 2018. Disponible en: https://minka.presidencia.gob.ec/ portal/usuarios externos.jsf

55 Ibídem.
} 
A su vez, se establecía la creación del "Comité Ejecutivo", el cual -encargado de llevar a la práctica las decisiones del primero- tendría como secretario al aludido historiador Juan Paz y Miño. En este nuevo esquema, la "Comisión Nacional Permanente de Conmemoraciones Cívicas” que, según el Decreto Ejecutivo $\mathrm{N}^{\circ}$ 561, debía iniciar las acciones relativas a la celebración bicentenaria, a partir de ese momento, sería "la encargada de prestar apoyo al Comité Presidencial y su Comité Ejecutivo".56 Veremos más adelante que el Poder Ejecutivo ecuatoriano haría coincidir la conmemoración bicentenaria de la Primera Junta de Gobierno de Quito con la segunda toma de posesión presidencial, enlazando - no sin polémicas- la celebración de la "primera" independencia al festejo de la continuidad política del gobierno. ${ }^{57}$

De manera simultánea, el gobierno de la RB se disponía, asimismo, a avanzar sobre sus celebraciones bicentenarias, poniendo fin a la incertidumbre en torno a cuándo éstas tendrían lugar. Por medio del Decreto $\mathrm{N}^{\circ}$ 6015, emitido meses después de la primera derrota política del chavismo, ${ }^{58}$ se conformaba -bajo el mando del entonces vicepresidente Ramón Carrizales- el "Comité Presidencial para la Conmemoración del Bicentenario de Independencia de la República Bolivariana de Venezuela"59 con el objetivo de programar las actividades festivas a realizarse entre el 19 de abril de 2010 y el 5 de julio de 2011. En cuanto a la "filosofía” detrás de éstas, la normativa rezaba:

\footnotetext{
${ }^{56}$ Ibídem.

${ }^{57}$ Me refiero a los reclamos que llegaban por aquellos días desde la costa, vinculados especialmente al hecho de que la celebración se haya concentrado en Quito, así como al uso político que se habría hecho de ella. Aunque también cabe señalar otro conflicto que, menos divulgado, rodeó a los festejos bicentenarios, el de la matanza de tres integrantes de una familia de "colonos" por miembros de una comunidad indígena en aislamiento voluntario el mismo 10 de agosto de 2009, episodio que sacó a relucir las dificultades asociadas a la penetración petrolera y tala ilegal en la llamada Zona Intangible Tagaeri Taromenane (ZITT) dentro del Parque Nacional Yasuní que, según denunciaba por aquellos días la opositora- Confederación de Nacionalidades Indígenas del Ecuador (CONAIE), propiciaba la destrucción de la biodiversidad, el desplazamiento indígena de sus tierras ancestrales y la violencia interétnica.

${ }^{58}$ Se trata del rechazo al proyecto de reforma constitucional presentado por el presidente y la Asamblea Nacional en 2007, el cual pretendía, entre otros puntos, convertir a Venezuela en un Estado socialista, aprobar la reelección presidencial indefinida y promulgar una Ley Habilitante que permitiera al presidente gobernar por decreto. Esta propuesta profundizaría el descontento tanto de los sectores opositores como de los aliados políticos del chavismo por considerarla un agravio a la Constitución y a la democracia participativa, respectivamente.
}

59 Decreto $\mathrm{N}^{\circ} 6015$ publicado el 17 de abril de 2008 en la Gaceta Oficial $\mathrm{N}^{\circ} 38.912$. Los sitios web en los cuales se solía encontrar dicha normativa ya no están disponibles. Véanse fragmentos de éstas en: https:// www.albicentenario.com/index_archivos/celebracion_continental_36.html 
La concebimos como la presencia entre nosotros de un proceso que comenzó a fines del siglo XVIII y aún continua.

Concebimos la celebración del Bicentenario de las Independencias, como un proceso vivo y actual, en el que todos debemos participar, porque nos corresponde como generación, concluir el proceso, que se inició en el siglo XIX y aún no concluye.

La concebimos como un proceso con tanta pertinencia en lo actual, que debemos enfrentar todas las distorsiones y tergiversaciones que se pretendan hacer de ese proceso.

La concebimos como un proceso nuestro americano que incluye a todos los pueblos que desde el siglo XIX luchan por su liberación.

La celebración de los bicentenarios deben convertirse desde Venezuela en una fiesta popular en la que los pueblos nuestros americanos sean los protagonistas. Las actividades desplegadas deben superar el carácter estrictamente oficial y académico que solían tener este tipo de eventos en tiempos de la cuarta república.

El protagonismo del pueblo debe expresarse en todas y cada una de las actividades incluyendo aquellas consideradas tradicionalmente como reservadas a la academia y a los sabios. Las investigaciones deben superar los paradigmas hegemónicos y dar paso al protagonismo de los saberes, las prácticas y la memoria popular. ${ }^{60}$

Casi al mismo tiempo, los Poderes Ejecutivos de Argentina, Ecuador y Venezuela sumaban decretos que creaban nuevos organismos, definían competencias, establecían y/o reiteraban metas y propósitos, reactivaban el relato bolivariano de la "patria grande" o delineaban las primeras acciones conmemorativas a implementar con vistas a las efemérides en cuestión. Ahora bien, el gobierno venezolano explicitaba, a su vez y a diferencia de sus pares, la necesidad de disputar abiertamente las interpretaciones no solo políticas, sino también historiográficas en torno a los procesos de independencia hispanoamericanos para, en cambio, favorecer el "protagonismo de los saberes, las 
prácticas y la memoria popular" en torno a dicho acontecimiento, cuya conclusión insistía la norma- era tarea del gobierno y su generación.

Respecto a los arreglos del bicentenario boliviano, el gobierno del MAS conservó el comité original instituido en el 2003, cuya presidencia correspondía -según la ley $\mathrm{N}^{\circ}$ 2501- al vicepresidente de la nación, Álvaro García Linera, mientras que el cargo de director ejecutivo fue delegado al escritor y periodista sucrense, Alex Aillón Valverde. Asimismo, se crearon nueve "Comités Departamentales del Bicentenario" para contribuir "con las labores del Comité Nacional de Conmemoración". ${ }^{1}$ Con vistas a ese objetivo, fueron organizados múltiples encuentros anuales en diferentes puntos del país, a los cuales el director ejecutivo se refirió de la siguiente manera: "esto compromete a nuestra dirección a plantear la integración de nuestro país a partir de los Comités Departamentales, es una tarea ardua, pero con un fin sólido, que es la unidad en torno al Bicentenario".62

Sin embargo y más allá de cierta apariencia de convergencia entre el Ejecutivo nacional y los representantes departamentales, así como de continuidad con lo establecido por los decretos firmados por Sánchez de Losada y Mesa Gisbert que buscaban revalorizar a la Revolución de Chuquisaca y, en estrecha relación, a la ciudad de Sucre, la organización del bicentenario de dicho acontecimiento en tanto festividad nacional vacilaba.

En efecto, Aillón declaraba a principios de abril de 2008 -en referencia a una reunión gestionada por el entonces viceministro de Culturas, Pablo Groux, con el fin de establecer un fondo concursable para la conmemoración bicentenaria- que "El Viceministro ha asumido un compromiso fundamental con el Bicentenario y eso es algo que nos alienta, puesto que hasta el momento no se ha podido articular con el Gobierno un agenda plena de conmemoración que pueda integrar al país". ${ }^{63}$ Lo que reprochaba el director ejecutivo era, entonces, la falta de adhesión y sostén por parte de la

\footnotetext{
61 Ley N² 2501 del 5 de agosto de 2003. Disponible en: http://anterior.gacetaoficialdebolivia.gob.bo/ normas/verGratis_gob/17873

62 Disponible en: http://comisionbicentenario.blogspot.com/2008/04/bicentenario-en-bolivia.html

63 Disponible en: https://www.bolivia.com/noticias/autonoticias/DetalleNoticia38054.asp
} 
vicepresidencia y aquellos otros ministerios nacionales que también formaban parte del comité. Tiempo después, el mismo explicaba:

El momento de ruptura se da fundamentalmente debido a la disputa por la capitalía y es la que rompe la celebración. La Vicepresidencia, y de hecho todo el Gobierno central, por un lado, y por el otro, todas las instituciones locales haciendo resistencia. Hubo varios intentos de aproximación, inclusive llegamos a reunimos en la Vicepresidencia con Álvaro García Linera y algunos ministros y con los perdedores del conflicto, para el caso, gente de la Alcaldía de Sucre y de la Gobernación chuquisaqueña; pero la confrontación no pudo salvarse. El Gobierno dejó la comisión, pues tenía otra línea de trabajo que al final se resolvió con una celebración en Tomina (localidad rural de Chuquisaca), a la que se trató de darle un carácter internacional. 64

Los graves conflictos que venían suscitándose desde el 2006 en el marco de la AC -debido al rechazo a la demanda del "Comité Interinstitucional de la Capitalidad" de incorporar al debate constitucional el retorno de los poderes del Estado a Sucre- habrían contribuido a tal escenario, reanimando, en vísperas del bicentenario de la Revolución de Chuquisaca pero también de la Primera Junta Tuitiva de Gobierno de La Paz, una vieja disputa de carácter historiográfica. De este modo, volvía a resonar con fuerza la pugna entre Sucre (bajo gobierno opositor) y La Paz (bajo gobierno aliado al MAS) por cuál de estos acontecimientos históricos debía ser considerado como la "cuna de la independencia" de Bolivia y Sudamérica.

Ahora bien, en el momento en que el gobierno central se decidió a retomar la agenda conmemorativa, la profundización de aquel clima de conflictividad política y social en la capital constitucional terminaría derivando en un drástico cambio de planes. Durante los días 24 y 25 de mayo de 2008, es decir, en ocasión del $199^{\circ}$ aniversario del levantamiento ocurrido en Chuquisaca, el Ejecutivo esperaba poder combinar dicha celebración con la II reunión del "Grupo Bicentenario", cuya secretaría pro tempore, en manos del comité boliviano, debía ser traspasada a Ecuador.

Empero, cuando la comitiva presidencial se preparaba para arribar a la ciudad, las protestas violentas organizadas por grupos opositores -quienes, además de la "plena 
capitalía", demandaban también el esclarecimiento de la muerte de tres universitarios ocurrida en noviembre de 2007 y un pedido de disculpas por parte de Morales-65 condujeron a que el viaje del mandatario fuera cancelado y a que parte del movimiento indígena-campesino, el cual había llegado aquel mayo de 2008 a Sucre para recibir a Morales, resultara fuertemente agraviado.

Así, veintiocho campesinos fueron obligados a desnudarse en la plaza principal, arrodillarse, besar el piso, repudiar al presidente y contemplar como sus wiphalas y ponchos eran prendidos fuegos mientras ellos eran insultados y amenazados con ser incinerados.66 Este episodio de violencia racial fue lo que marcó un punto de quiebre definitivo entre el gobierno central y las autoridades de la ciudad de Sucre con quienes se suponía que debía coordinar las acciones bicentenarias durante el año que quedaba por delante.

Respecto a la reunión del "Grupo Bicentenario", éste sesionó, a pesar de los hechos, en la Casa de la Libertad de Sucre encabezada por el director ejecutivo del comité y el -opositor- presidente de la Corte Suprema de Justicia sin ninguna participación del gobierno central, el cual -a raíz de ese episodio- terminaría trazando su propio festejo para los doscientos años de lo que, tiempo después, sería denominado "Bicentenario de los Pueblos 2009-2025".

Cerrando este camino rumbo a los bicentenarios, el gobierno kirchnerista emitiría un último decreto en septiembre de 2009 bajo un particular clima político y social motivado por la masiva movilización ruralista y de sectores medios urbanos surgida en

\footnotetext{
65 Conocido como "las muertes de La Calancha", este suceso fue consecuencia de la represión policial a las manifestaciones y protestas opositoras surgidas luego de que la Dirección de la AC decidiera trasladarse de su sede oficial -el Teatro Gran Mariscal de Ayacucho- a un cuartel militar en las afueras de Sucre para aprobar el cambio de sede de la AC a la ciudad de Oruro. Esto, a su vez, derivó en la renuncia y huida del entonces prefecto oficialista de Chuquisaca, David Sánchez.

66 Este episodio violento tuvo otro antecedente ocurrido el 6 de agosto de 2007 en Sucre cuando Morales, luego de pronunciar un discurso en la Casa de la Libertad en ocasión del $112^{\circ}$ aniversario de la independencia, se vio obligado a abandonar la capital constitucional en medio de un ambiente hostil incitado por grupos opositores que abuchearon al mandatario con insultos como "fuera, indios" o "fuera, llamas" y corearon, en referencia a la líder campesina de origen quechua elegida por el MAS para presidir la AC, consignas como "Silvia Lazarte, chola ignorante". Clarín, 22 de agosto de 2007. Disponible en: https://www.clarin.com/ediciones-anteriores/bolivia-gobierno-impulsa-reeleccion-indefinidaevo 0 H1ZCylJRKx.html

De igual modo, en septiembre de 2008 las acciones de violencia racial contra el movimiento indígenacampesino llegarían a su punto álgido con la denominada "masacre de Porvenir" en Pando, la cual consistió en el asesinato de trece campesinos por parte de empleados de la Prefectura del mencionado departamento opositora al gobierno del MAS.
} 
la primera mitad del 2008, la cual -tras paralizar al país- "culminó con la [hasta ese entonces] mayor derrota política experimentada por las administraciones de Néstor y Cristina Kirchner desde su arribo a la presidencia en mayo de 2003" (Hora, 2010: 81), esto es, el inesperado revés en las elecciones legislativas de junio de ese mismo año.

Este escenario -que obligaría al gobierno kirchnerista a reconstruir su legitimidad política e intentar una nueva articulación hegemónica- fue el que sirvió de trasfondo a la planificación y ejecución de los actos del bicentenario; los cuales se iniciaron, finalmente, en octubre de 2009 luego de la firma de aquella última normativa que establecía la creación de la "Unidad Ejecutora del Bicentenario de la Revolución de Mayo" con el objetivo de administrar los bienes, servicios y contrataciones relativos a la celebración. ${ }^{67}$ Javier Grosman, caracterizado posteriormente como el "arquitecto estético del kirchnerismo", ${ }^{68}$ fue nombrado su director ejecutivo, acompañando, de esta manera, a la entonces presidenta de Argentina, su secretario general, Oscar Parrilli, y el -en ese entonces, nuevo- secretario de Cultura, Jorge Coscia, en la proyección de los festejos.

De modo que la producción de los regímenes conmemorativos de los bicentenarios de "independencia" se impuso, en algunos casos más tempranamente que en otros, como un objeto de preocupación compartido, lo cual se vio reflejado no tanto en los intentos por articular y organizar las celebraciones a través de instancias supranacionales -que, en verdad, solo se tradujeron en acciones conmemorativas de carácter más bien lateral-, sino, sobre todo, en la creciente sucesión de maniobras dirigidas a (re)elaborar sus marcos normativos, establecer los actores responsables de su concepción y ejecución, definir las fechas a ser celebradas y/o delinear los primeros gestos conmemorativos.

\footnotetext{
${ }^{67}$ Decreto $N^{\circ} 1358$ del 30 de septiembre de 2009. Disponible en: http://www.saij.gob.ar/1358-nacionalcreacion-unidad-ejecutora-bicentenario-revolucion-mayo-1810-2010$\underline{\mathrm{dn} 20090001358-2009-09-30 / 123456789-0 \mathrm{abc}-853-1000-9002 \text { soterced }}$
}

${ }^{68}$ La Nación, 17 de julio de 2017. Disponible en: https://www.lanacion.com.ar/2044787-javier-grosmanla-estetica-de-cristina-no-tuvo-olor-a-choripan-en-la-pantalla 
Con todo y más allá de los paralelismos o continuidades producto de los vínculos y cierto "efecto de repercusión" entre los cuatro casos en cuestión, veremos a lo largo de este trabajo que cada régimen conmemorativo fue evolucionando y (re)definiéndose de modo particular atendiendo mayormente a las cambiantes circunstancias y dinámicas políticas internas, a las diferentes tradiciones e improntas invocadas, a la pertenencia de sus principales figuras a un determinado linaje $y$, en estrecha relación, a los intereses y/u objetivos que cada Poder Ejecutivo se propuso satisfacer, conduciendo todo ello a formas diferentes de conmemorar y disputar la nación.

\section{Los eventos oficiales del bicentenario. Programas, escenarios y puestas en} escena

Hacia los primeros días de mayo de 2009 ya se sabía que el gobierno del MAS se ausentaría de las celebraciones bicentenarias planificadas en la ciudad de Sucre y que la vicepresidencia del Estado Plurinacional -en calidad de máximo responsable del "Comité Nacional de Conmemoración del Bicentenario del Primer Grito Libertario en América del 25 de Mayo de 1809"- se encontraba organizando, junto a la Federación de Campesinos de Chuquisaca, un festejo paralelo en distintos puntos rurales de los departamentos de Potosí y Chuquisaca, atribuyéndose dichas decisiones a los episodios violentos ocurridos durante el aniversario patrio del 2008.

De esta manera, el jueves 21 de mayo García Linera confirmaba -a través de una conferencia de prensa- que el llamado "Bicentenario de los Pueblos 2009-2025" se inauguraría al día siguiente con una concentración de organizaciones indígenas y campesinas encabezada por el presidente en el municipio de Ravelo, una localidad mayoritariamente quechua ubicada en la provincia de Chayanta del departamento de Potosí, por haber sido aquella provincia cuna de los hermanos Katari, Juana Azurduy y, su esposo, Manuel A. Padilla. 
El programa elaborado por el Poder Ejecutivo boliviano continuaba el sábado 23 con otra ceremonia a realizarse, esta vez, en Chataquila, un poblado del departamento de Chuquisaca donde murió asesinado Tomás Katari. Allí, además de homenajearse al líder del levantamiento indígena y desarrollarse una fiesta comunitaria, el Instituto Nacional de Reforma Agraria efectuó la entrega de "Títulos Ejecutoriales", esto es, títulos de propiedad sobre la tierra, a familias campesinas de la provincia de Oropeza. Asimismo, Flora Aguilar de la Confederación Nacional de Mujeres Campesinas Indígenas Originarias de Bolivia "Bartolina Sisa" (CNMCIOB-BS) y la entonces ministra de Justicia, Celima Torrico, fueron las encargadas de, discurso mediante, abrir y cerrar la jornada.

El domingo 24 de mayo y la capital constitucional fueron el día y lugar elegidos para presentar la normativa que declaraba a la mencionada fecha como "Día nacional de lucha contra la discriminación racial". Sin la presencia del mandatario -quien decidió, a último minuto, viajar a Ecuador para rendir homenaje al $187^{\circ}$ aniversario de la Batalla de Pichincha-, la Federación Única de Trabajadores de Pueblos Originarios de Chuquisaca (FUTPOCH) y la CSUTCB fueron los responsables de organizar un acto de desagravio y reconocimiento a los campesinos humillados un año atrás, el cual involucró varias alocuciones y presentaciones musicales, así como una concentración y un desfile campesino por el centro de la ciudad hasta arribar a la plaza Tomás Katari, donde el viceministro de Descolonización hizo entrega de un "mojón conmemorativo".

Finalmente, el escenario escogido para la celebración del 25 de mayo fue El Villar, otra pequeña localidad rural del altiplano boliviano cargada también de significaciones culturales y simbólicas en la medida que allí se ubicó el cuartel de operaciones de Juana Azurduy de Padilla en los dieciséis años que duró la guerra por la independencia. Una crónica de aquel día narraba:

Este pueblo enclavado en medio de un complejo de colinas verdes, trepado a menos de $1.000 \mathrm{~m}$ de altura sobre el nivel del mar, se ha vestido de fiesta para recibir a Morales (...) El acto central, emplazado en una pradera de hierba uniforme, se desarrolló lejos de los salones tradicionales (...), en medio de un sol que caía a plomo sobre los visitantes y también sobre los lugareños, que montados a horcajadas sobre sus caballos seguían desde la colina, cual tribuna, los actos de protocolo sin paragón. (...) Miles de lugareños y afuereños le recibieron con 
alborozo y la banda militar que ejecutó todas las estrofas de la canción nacional, elevó el acto hasta la cumbre de los sentidos. Más aún, cuando esos soldados indígenas, de rostro cetrino, enfundados en trajes que hacían sudar hasta a los ajenos, entonaron a viva voz la chacarera llevada a ritmos marciales "La Patria".

Lejos de los "salones tradicionales", con la entonación del himno nacional y con la lectura del Acta de Independencia en castellano, quechua, aymara y guaraní, se inauguraba, así, el evento central del bicentenario de la Revolución de Chuquisaca proyectado por el MAS. La inusual jornada continuó con una serie de espectáculos de baile y música popular, así como con un conjunto de discursos pronunciados por el alcalde del municipio, una representante de la FUTPOCH, García Linera y Morales quien había vuelto de Ecuador especialmente para asistir a la ceremonia-. Tras las alocuciones, tuvo lugar la presentación de las monedas conmemorativas del bicentenario.

Posteriormente, el ejecutivo de la CSUTCB, Isaac Ávalos, obsequió al presidente una chaqueta tipo militar similar a la que usaban los próceres de la independencia proclamándolo, no sin despertar controversias, "Libertador de los pueblos", lo cual fue acompañado de un desfile cívico-militar en homenaje a Juana Azurduy, Manuel Ascencio Padilla y Tomás Katari que, al compás de la chacarera "La Patria" llevada a ritmos marciales, congregó a la caballería y la banda escolar, campesinos e indígenas, las Fuerzas Armadas y la Policía Nacional. Finalmente, la jornada concluyó con una tradicional fiesta comunitaria.

A diferencia de cómo había ido proyectándose durante los años previos, el bicentenario de la Revolución de Chuquisaca delineado por el gobierno del MAS fue concebido ya no como el único a ser distinguido y elevado a festividad nacional, sino más bien como el punto de partida de un ciclo conmemorativo mayor, esto es, el "Bicentenario de los Pueblos 2009-2025". Con esta denominación, el Poder Ejecutivo moderaba -en un clima de abierta hostilidad entre las dos capitales y sus respectivos gobiernos- el protagonismo del "primer grito libertario de América" -y, en estrecha relación, de Sucre- al tiempo que incluía y reivindicaba al bicentenario de la "Primera Junta Tuitiva de Gobierno" de La Paz como el otro acontecimiento fundamental para la independencia del país y de la región. 
Es así que, menos de dos meses después y con una marcha de caballería que partió el lunes 13 de julio de 2009 desde El Villar con destino final a La Paz, se reanudaban en Bolivia los festejos del bicentenario. De todos modos, no fue en la capital sino en la localidad andina de Patacamaya donde el Poder Ejecutivo boliviano inauguró oficialmente la semana del bicentenario.

El miércoles 15 de julio los actos conmemorativos prosiguieron, en esta ocasión, con una serie de ceremonias oficiales protagonizadas por el presidente y el entonces alcalde de la ciudad, Juan del Granado, reunidos en la casa de Pedro D. Murillo, donde además de leerse la proclama de la Junta Tuitiva e izarse las banderas paceña y boliviana, se encendió la Tea de la Libertad. ${ }^{69}$ Luego de entonadas las estrofas del himno al Departamento de La Paz, Morales y del Granado encabezaron el tradicional desfile de teas en el centro de la capital. Todas puestas en escena que sirvieron de preámbulo a los fastos bicentenarios propiamente dichos, los del 16 de julio.

Esta jornada se inició en la mañana con una ceremonia interreligiosa efectuada en la Catedral Metropolitana Nuestra Señora de La Paz, la cual contó con la participación del presidente, quien hacia el final, se retiró -junto a la comitiva de Jefes de Estado y cancilleres invitados a los festejos- a un "almuerzo de camaradería" en el hotel Radisson. A continuación, se realizó la "Parada militar bolivariana de los pueblos", la cual contó con la participación de tropas provenientes de Argentina, Paraguay, Bolivia, Ecuador, Perú y Venezuela que marcharon por la avenida Germán Busch hacia la Plaza Villarroel. Igualmente, la "Feria de Identidades Paceñas", el "Festival Artístico del Bicentenario" y, por último, el "Desfile cívico del Bicentenario" formaron parte del programa paceño para aquella tarde del 16 de julio.

Tres semanas después llegaba el turno de Ecuador, en donde el gobierno de la RC no solo se disponía a celebrar el bicentenario de la Primera Junta de Gobierno de Quito, sino también su rotundo triunfo en las elecciones generales de abril de 2009. Es que el 10 de agosto resultó ser la fecha elegida por las autoridades nacionales para llevar a

\footnotetext{
69 Según reza el mito, fue el héroe criollo quien la prendió por primera vez antes de subir a la horca en enero de 1810 cuando fue ejecutado por las autoridades peninsulares. En esta ocasión, el encendido de la Tea en tendría como preludio la marcha de jóvenes andinos que partieron desde las ruinas de Tiwanaku con la "Llama de la Libertad" hacia el Municipio de Laja, lugar en el que se pasó la posta a un conjunto de deportistas de El Alto encargados de trasladarla a La Paz.
} 
cabo la segunda posesión presidencial de Correa, enlazando, de esa manera, su victoria política a un momento ejemplar de la historia ecuatoriana. ${ }^{70}$

Con Silvio Rodríguez como protagonista, los actos del bicentenario se iniciaron anticipadamente el 7 de agosto de 2009 cuando el cantautor cubano -acompañado de artistas nacionales- se presentó en el estadio Alberto Spencer de la ciudad de Guayaquil ante un público de más de 40 mil personas, entre los cuales se encontraba Correa, en el marco de un concierto gratuito denominado "La libertad es una fiesta". En seguida y apoyados sobre las consignas "La memoria política de los pueblos", "La libertad son los pueblos", "Vive el 10 de agosto" y "Vive la Cultura", los festejos continuaron en la capital ecuatoriana el 9 de agosto con un abanico variopinto de actividades: rituales, exposiciones, desfiles, proyecciones y conciertos, estimándose alrededor de 400 actos y 900 artistas involucrados.

El evento elegido para inaugurar la "velada libertaria" del 9 fue la toma de posesión simbólica del mando presidencial a través de un ritual indígena-ejecutado por los taitas y mamas en la localidad de Cayambe en el que resultó ser el día internacional de los pueblos indígenas-. Allí, los líderes de la comunidad entregaron a Correa un poncho de color rojo en alusión a la tierra del país junto a una medalla con el escudo de la cruz de los pueblos indígenas y un bastón de mando que significaba la transmisión de los conocimientos de la tierra.

Este acto -que involucró, a su vez, la apertura del Centro Intercultural Comunitario “Tránsito Amaguaña"-71 contó con la presencia de Evo Morales y Rigoberta Menchú, quienes también recibieron las bendiciones de un ritual de limpieza y la medalla "Bicentenario" como símbolo de libertad de las comunidades por parte del entonces ministro de Cultura, Ramiro Noriega.

Paralelo a la ceremonia indígena, se efectuó por primera vez el "Desfile de la Ecuatorianidad", el cual contó con la participación de 24 carrozas inspiradas en la cultura e historia de cada una de las provincias de Ecuador. El objetivo, declaraba la

\footnotetext{
70 Cabe recordar que el 15 de enero de 2007, fecha en que se efectuó la primera posesión presidencial, Correa convocó a una consulta popular para decidir la creación de la AC dirigida a redactar una nueva constitución, la cual establecía -entre otros puntos- el llamado a elecciones generales en abril de 2009, es decir, la renovación o confirmación de todas las autoridades estatales de Ecuador.

71 En honor a la activista indígena y referente feminista fallecida el 11 de mayo de 2009, este espacio fue presentado como un centro de investigación de los pueblos de los Andes.
} 
ministra de Turismo Verónica Sión, era "poner de manifiesto cada una de las grandes riquezas de orden histórico, turístico y cultural" del país. ${ }^{72}$ Posteriormente y ya con la presencia del mandatario, se desarrolló un desfile militar dirigido a representar la historia de las Fuerzas Armadas de Ecuador, en el cual marcharon los pelotones de las fuerzas terrestre, aérea y marítima, los soldados Iwias -grupo de elite integrado por nativos amazónicos-, los "héroes" de Paquisha y del Cenepa -que participaron de los enfrentamientos militares entre Ecuador y Perú en 1981 y 1995, respectivamente- y los granaderos de Tarqui.

Organizado por la Casa de la Cultura Ecuatoriana, la actividad infantil "Pavimento de Color" también formó parte de la agenda conmemorativa del bicentenario ecuatoriano, precediendo al novedoso despliegue escenográfico protagonizado por actores y actrices profesionales que, disfrazados de figuras patrióticas, se ubicaron en las catorce plazas de la ciudad, cada una de las cuales representó distintos escenarios y episodios históricos: el de la diversidad con Eloy Alfaro Delgado; el de la libertad con Antonio José de Sucre y Mariana Carcelén; el de la resistencia andina con Rumiñahui y Tupac Amaru; el de la ideología libertaria con Simón Bolívar y Manuela Sáenz; el de lo ancestral con Rosa Zárate, Rosa Campuzano, Tránsito Amaguaña y Dolores Cacuango; el de las tradiciones con Manuela Cañizares y Manuela Espejo; el de la academia con Manuel Rodríguez Quiroga y Juan de Dios Morales; el de los Barrios y Parroquias con Francisco Calderón y Abdón Calderón; el de la expresión con Carlos Montúfar y Juan Pío Montúfar; el del encuentro infantil y la diversidad con Eugenio Espejo, José Mejía y José Joaquín de Olmedo; y el de la paz con Juan José de Salinas y Zenitagoya. El final de esta jornada conmemorativa ocurrió en la plaza de la Independencia, en donde se desarrollaron dos actos centrales: un concierto de la orquesta sinfónica y un mensaje presidencial emitido por cadena nacional de radio y televisión. ${ }^{73}$

\footnotetext{
72 Soitu, 7 de agosto de 2009. Disponible en: http://www.soitu.es/soitu/2009/08/07/info/1249668153 437996.html

73 Como la celebración se emplazó en la capital, el resto de las provincias del país estuvieron enlazadas vía satélite, y en las plazas principales de cada capital de provincia se instalaron pantallas gigantes, en un intento - no exento de rencillas- por integrar el territorio nacional y menguar las tendencias centralistas.
} 
Al otro día, es decir, durante el 10 de agosto, las actividades se ciñeron, en la mañana, a las ceremonias protocolares de posesión tanto del segundo mandato presidencial como de la presidencia pro tempore de la UNASUR ante la Asamblea Nacional y delegaciones de distintos países. Hacia la tarde y como broche final de los actos del bicentenario, los festejos populares volvieron a cobrar protagonismo con un recital encabezado por el grupo de folclore argentino "Los Nocheros" en el estadio olímpico Atahualpa, en donde se había realizado otra posesión simbólica de Correa.

El siguiente país en inaugurar sus celebraciones bicentenarias fue Venezuela, en donde el gobierno de la RB se propuso -como medidas iniciales vinculadas a la ocasión- ${ }^{74}$ crear e instalar el 6 de abril de 2010 la "Sociedad Bolivariana Estudiantil Bicentenaria" - con el objetivo de transmitir el ideario del libertador en las escuelas públicas del país-, así como impulsar la reunión del Consejo de Mujeres de la Alianza Bolivariana para los Pueblos de Nuestra América (ALBA) para los días 10 y 11 de ese mes.

Asimismo, aquél intentaría concretar una primera reunión de la Quinta Internacional Socialista, cuya propuesta de lanzamiento había realizado Chávez en el marco del "Primer Encuentro Internacional de Partidos de Izquierda" en noviembre de 2009 en Caracas. Según el entonces viceministro para el Fomento de la Economía Cultural, Pedro Calzadilla, esta iniciativa -a realizarse los días 12 y 13 de abril en la ciudad capital- surgía "en virtud de la necesidad de reagrupar fuerzas de izquierda internacionales (...) de la esperanza de que el Socialismo es posible".75

También para el 13 de ese mes se planificaron un desfile cívico-militar en el Paseo Los Próceres, una concentración en la avenida Bolívar, el lanzamiento de la "Operación Trueno Comunicacional" - esto es, una suerte de comando formado por 75 jóvenes cuyo objetivo principal era "combatir" los mensajes transmitidos por los medios de comunicación hegemónicos-, la presentación de la "Serie Colección bicentenario" -la

\footnotetext{
${ }^{74}$ En verdad, la primera disposición por parte de la RB ligada a la conmemoración del bicentenario fue renombrar, una vez expropiada y nacionalizada a mediados de enero de 2010, a la cadena de supermercados franco-colombiana denominada "Éxito" como "Hipermercados Bicentenario".

75 Disponible en: http://albaciudad.org/2010/04/gobierno-anuncia-eventos-preparandose-para-la-granfiesta-bicentenaria-del-19-de-abrill. Sin embargo y más allá de su llamamiento, este encuentro, finalmente, no sucedió. Luego de su anuncio el 5 de abril de 2010, ni el gobierno de la RB ni otras agencias involucradas en la propuesta se refirieron a la cuestión. Véase: https:// vinternacional.wordpress.com/2010/04/
} 
cual involucraba la publicación de estudios y documentos relativos a la independencia, así como textos escolares de Matemática, Lengua, Ciencias Naturales y Ciencias Sociales de distribución gratuita- y, finalmente, el "Concierto Internacional por la Canción Contestataria" en la plaza Venezuela.

Es que, además de enmarcarse en los festejos del bicentenario, aquellas actividades desplegadas a lo largo del 13 de abril de 2010 estuvieron especialmente destinadas a celebrar el octavo aniversario de la restitución en el poder del presidente venezolano tras el intento de golpe de estado del 2002. De hecho, el día anterior Chávez había declarado -mediante el decreto $\mathrm{N}^{\circ}$ 7362- a la fecha en cuestión como "Día de la Milicia Nacional Bolivariana, del Pueblo en Armas y de la Revolución de Abril”, otorgándole, asimismo, "el carácter de día de Júbilo Nacional”.

Los eventos conmemorativos continuaron cinco días después cuando, en las vísperas del aniversario patrio, tuvieron lugar un concierto denominado la "Fiesta de los Pueblos del Mundo", una emisión especial por cadena nacional de radio y televisión protagonizada por Chávez y la inauguración del "Monumento al 19 de abril" en la plaza El Venezolano. Con respecto a la jornada del 19 de abril, se programaron, en su mayoría, ceremonias de carácter oficial y protocolar. Luego del llamado "Amanecer Bicentenario" - una serie de actividades recreativas en todas las plazas Bolívar del país para celebrar la llegada del día patrio-, la efeméride comenzó en la mañana con un homenaje a Simón Bolívar en el panteón nacional en donde Chávez y mandatarios de varios países de América Latina y el Caribe dejaron una ofrenda floral al pie de la tumba del prócer.

Concluidos los honores, la comitiva de presidentes se trasladó hacia el Paseo Los Próceres donde el mandatario venezolano, luego de pronunciarse frente al público, dio inicio al desfile denominado "Independencia y Revolución", en el cual estudiantes, deportistas, grupos folklóricos, indígenas, mineros, trabajadores de la industria alimentaria y obreros de Petróleos de Venezuela marcharon durante casi cuatro horas junto a la Fuerza Armada Nacional Bolivariana y la Milicia Bolivariana. ${ }^{76}$

\footnotetext{
76 Evocando a las fuerzas milicianas del período independentista y apelando al principio de corresponsabilidad, cabe señalar la creación, en 2007 por medio de un decreto presidencial, de un cuerpo especial conformado por civiles - principalmente, campesinos, obreros y pueblos originarios- como complemento de la Fuerza Armada Nacional Bolivariana para la ejecución de la defensa integral de la Nación.
} 
La conmemoración patria continuó con una sesión solemne en la Asamblea Nacional, donde la entonces presidenta argentina, Cristina Fernández de Kirchner, fue la figura elegida por Chávez para pronunciar el discurso de orden. Finalmente, el cierre de la fiesta se produjo en las instalaciones del Teatro Teresa Carreño donde se llevó a cabo con la IX Cumbre del ALBA, en la cual se firmó una declaración conjunta por el aniversario del inicio del proceso de independencia venezolana y se suscribieron acuerdos en materia comercial y política.

Un mes más tarde tomaba la posta el gobierno de Fernández de Kirchner, el cual se había propuesto construir el llamado "Paseo del Bicentenario" a lo largo de la Avenida 9 de Julio para alojar la mayoría de las actividades principales que caracterizaron a la celebración oficial. Este espacio al aire libre fue inaugurado la tarde del 21 de mayo por la presidenta junto a la "Feria de las Provincias" donde cada una de éstas expuso su historia, arte y geografía; un paseo gastronómico con 72 puestos de comida distribuidos entre las provincias, organizaciones sociales y comunidades inmigrantes; y una serie de pabellones en donde los distintos ministerios de la Nación buscaron difundir -a través de instalaciones, charlas y proyecciones audiovisualestemáticas y avances relativos a Ciencia y Tecnología, Juventud y Educación, Medio Ambiente, Cultura, Derechos Humanos y Producción.

Para el día siguiente, se planeó un desfile militar que reunió alrededor de 5 mil efectivos pertenecientes a delegaciones militares extranjeras (Brasil, Uruguay, Bolivia, Ecuador y Venezuela), institutos militares, regimientos históricos, fuerzas de seguridad nacionales y ex combatientes de Malvinas. Sin la presencia del Poder Ejecutivo nacional, su cierre estuvo a cargo del Regimiento de Granaderos a Caballo, el cual cantó a viva voz la Marcha de San Lorenzo.

Durante esa jornada también tuvo lugar el "Desfile Federal", a partir del cual se buscaron exhibir las distintas tradiciones y culturas del país - a criterio de cada gobierno provincial- a través de comparsas, murgas, carrozas y comunidades con trajes autóctonos de cada región. La recreación de la fiesta de la vendimia y espectáculos musicales - protagonizados por Abel Pintos, Juan Falú, Los Tekis, León Gieco, Jaime Roos, Pablo Milanés y Gilberto Gil- completaron el repertorio festivo del 22 de mayo. 
La programación para el 23 involucró otro desfile, el de la "Integración”, el cual contó con la participación de 4 mil integrantes de ochenta colectividades nacionales y de países invitados. Presidido por el entonces Ministro de Asuntos Exteriores, Jorge Taiana, las comunidades italiana, japonesa, escocesa, boliviana, árabe, china, brasilera, irlandesa, griega y paraguaya, entre otras, marcharon con trajes típicos y banderas por ocho cuadras del Paseo hasta el Obelisco. El último acto de la jornada fue, al igual que el día anterior, otro espectáculo musical de tango y folclore en el que participaron Gustavo Santaolalla, Soledad, Víctor Heredia, Teresa Parodi, Liliana Herrero y Peteco Carabajal.

Para el cuarto día de la "semana del bicentenario" se decidió, en primer lugar, que una caravana de autos y motos antiguas recorriera la avenida 9 de Julio y, a continuación, la transmisión por pantallas gigantes del último partido de la Selección antes del Mundial. De igual modo, se estipuló para el 24 de mayo la inauguración del Centro Cultural del Bicentenario -hoy Centro Cultural Néstor Kirchner- en el ex Palacio de Correos y Comunicaciones. El final de la jornada culminó con la actuación de la Orquesta Sinfónica Nacional que interpretó bandas de sonido del cine argentino, así como con la entonación del himno nacional transmitido en vivo por cadena nacional de radio y televisión desde el Valle de la Luna a las 00 horas del 25 de mayo.

Luego de la realización del histórico tedéum oficiado por el arzobispo Agustín Radrizzani -junto a representantes de diferentes cultos- en la basílica de Luján, el último día de la "semana del bicentenario" prosiguió con la inauguración de la "Galería de los Patriotas Latinoamericanos del Bicentenario" en la Casa de Gobierno, esto es, una muestra permanente donde se expusieron -hasta el 2016 cuando se decidió su traslado a la ex ESMA- más de 40 retratos de importantes figuras de la historia latinoamericana enviadas por los distintos gobiernos de la región. Posteriormente, se proyectó sobre la facha del Cabildo un videomapping de once minutos que sintetizó la historia nacional, después del cual más de 2 mil artistas llevaron a cabo el "Desfile de los 200 años" dirigido a narrar, a través de 19 cuadros temáticos, una serie de momentos paradigmáticos de la historia argentina. 77

\footnotetext{
77 Es preciso señalar que en el "Desfile de los 200 años" el asesor en cuanto a su contenido histórico fue Felipe Pigna, mientras que el encargado de realizar esta tarea fue, en el caso del videomapping, Javier Trímboli.
} 
Un nuevo recital conducido por Fito Páez fue el evento elegido para clausurar los festejos conmemorativos, quien -acompañado de personalidades del mundo de la música, la actuación y el deporte- interpretó, además de su obra, el himno nacional en un escenario acompañado de un importante letrero luminoso que, en celeste y blanco, alternaba las frases "somos capaces" y "viva la patria".78 Ahora bien, el último acto oficial de la jornada tuvo lugar ya no en la calle sino en la Casa de Gobierno, donde Fernández de Kirchner ofreció una cena de gala a múltiples presidentes latinoamericanos, dirigentes empresariales y sindicales, artistas, deportistas, escritores, representantes de diferentes iglesias, científicos, legisladores oficialistas y de la oposición.

Rematando este trayecto conmemorativo, fue el gobierno de la RB quien, nuevamente, se encargaría de diseñar otra celebración bicentenaria, esta vez, en ocasión del aniversario de la firma del Acta de la Declaración de Independencia. Sin embargo, las circunstancias de este extenso festejo serían notablemente distintas a las del año anterior debido, entre otras cosas, al sorpresivo anuncio en junio de 2011 de que Chávez se encontraba enfermo y se quedaría en La Habana recibiendo tratamiento médico por tiempo indeterminado.

De modo que la vicepresidencia de la República Bolivariana fue la responsable de reanudar, planificar y encabezar las actividades conmemorativas en Caracas, las cuales comenzaron el 28 de junio con la presentación oficial de una nueva emisión filatélica alusiva al Bicentenario y al Día del Ejército en la antigua sede del Correo de Carmelitas

\footnotetext{
78 La participación de Fito Páez en los festejos del bicentenario y otros "recitales kirchneristas" que tuvieron lugar tiempo después -razón por la cual sería catalogado como "ícono cultural del kirchnerismo"- despertó algunas controversias por el valor que tuvieron sus contratos, las cuales se profundizaron con el pronunciamiento que realizó el artista en Página 12 luego de que triunfara Mauricio Macri de Propuesta Republicana (PRO) en las elecciones de julio de 2011 en la ciudad de Buenos Aires frente al candidato kirchnerista, Daniel Filmus. En esa ocasión, Páez avivaría la polémica al sostener: "Nunca Buenos Aires (...) estuvo más lejos de ser esa ciudad deseada por todos. Hoy hecha un estropajo, convertida en una feria de globos que vende libros igual que hamburguesas, la mitad de sus habitantes vuelve a celebrar su fiesta de pequeñas conveniencias. (...) Da asco la mitad de Buenos Aires. Hace tiempo que lo vengo sintiendo (...) Buenos Aires quiere un gobierno de derechas. Pero de derechas con paperas".

Sobre esto último, véase Página 12, 12/07/2011. Disponible en: https:/www.pagina12.com.ar/diario/ contratapa/13-172084-2011-07-12.html

Respecto a la polémica por los contratos y su "afinidad" con el kirchnerismo, véase: Clarín, 21/06/2013. Disponible en: https://www.clarin.com/politica/fito-paez-millones-recitaleskirchneristas 0 HyvgJZviDXx.html
} 
en Caracas. ${ }^{79} \mathrm{El}$ cronograma oficial continuó los dos días siguientes con la inauguración de un conjunto de edificios emblemáticos localizados en el centro histórico de la capital que el gobierno restauró, especialmente, para la ocasión.

El inicio del "mes Bicentenario" se abrió con una jornada de movilización en uno de los bastiones del chavismo, el barrio y la iglesia denominados Parroquia 23 de febrero -en alusión a la fecha en que el general Marcos Pérez Jiménez fue derrocado-, sitio donde, cabe destacar, tuvieron lugar las primeras protestas del Caracazo. Elegido por su papel en la "lucha revolucionaria", las actividades allí desplegadas consistieron, por lo tanto, en una misa en la iglesia San Pedro Claver, un desfile protagonizado por jóvenes estudiantes y la Milicia Nacional Bolivariana y el izamiento de la bandera Francisco de Miranda.

Al día siguiente, los actos principales involucraron la inauguración de una exposición itinerante llamada "Génesis de la Identidad. Una lectura histórica del arte nacional" en la Galería de Arte Nacional, así como del -recientemente restauradoPaseo Los Próceres, donde se presentó la popular banda de merengue caraqueño, Los Antaños del Stadium. De igual manera, se organizaron en diferentes plazas de la capital dos espectáculos, uno con bandas marciales y otro llamado "Canción Necesaria”.

Para la jornada del 3 de julio se estipuló una marcha de la Juventud Patriótica y Antiimperialista que culminó con un concierto juvenil y, para la del 4 -declarada como día no laborable-, se efectuaron, nuevamente, varias inauguraciones: una exposición de piezas textiles y metálicas de objetos que pertenecieron a Simón Bolívar en el Museo Bolivariano, la reapertura del Boulevard de Sabana Grande con actividades culturales, otra exposición denominada "Recorrido histórico de la pintura venezolana" y la muestra "Cartel Bicentenario" - la cual consistió en la elaboración de una serie de afiches inspirados en las ideas de independencia, imperialismo y revolución por parte de 42 artistas plásticos de Cuba, Bolivia, Venezuela y México-.

Respecto al 5 de julio, éste fue recibido a las 00 horas con el himno nacional, fuegos artificiales y toques de campana en las parroquias y de diana en los cuarteles de

\footnotetext{
79 Según explicaba el vicepresidente Elías Jaua, la figura elegida para tal emisión correspondía a “(...) una obra pictórica que representa la reunión de la Sociedad Patriótica del día 3 de julio del año 1811. La obra es del pintor Tito Salas y se encuentra en la Casa Natal del Libertador Simón Bolívar”. Disponible en: https://www.mppeuct.gob.ve/actualidad/noticias/nueva-emision-filatelica-en-conmemoracion-albicentenario-y-los-190-anos-del
} 
todo el país. Hacia la mañana continuó con la izada de la bandera nacional, la apertura del arca que contiene el Acta de Independencia en la Asamblea Nacional y el rendimiento de honores ante la estatua del Simón Bolívar, seguido por el evento central de la jornada, esto es, un desfile cívico-militar realizado en el Paseo Los Próceres e inaugurado por Chávez - quien había aterrizado por sorpresa en Venezuela la madrugada del 4- a través de cadena nacional de radio y televisión desde el salón Simón Bolívar ubicado en el Palacio Miraflores. El final de la jornada patria se produjo en la plaza Diego Ibarra, la cual fue reinaugurada con la presentación de la Orquesta Sinfónica de Venezuela.

A lo largo de los días siguientes, los actos conmemorativos se extendieron con la llamada "Toma cultural de Caracas", es decir, múltiples exposiciones de artesanías, fotografía, pintura y artes escénicas, el "Encuentro de saberes ancestrales", un festival gastronómico y otro infantil, así como conciertos de música en vivo. Igualmente y en ocasión de los 200 años de la presentación por parte de Francisco de Miranda de la propuesta de bandera Nacional ante el Supremo Congreso de la Nación, se desarrolló un desfile de niños que entregó a la Asamblea Nacional la bandera de 1811. El estreno nacional de la película para televisión "Insurrección Bicentenaria" y la distribución de réplicas del Acta de Independencia por todo el país se sumaron, también, al repertorio de actividades festivas.

Hacia el 12 de julio, otro acto de importancia tuvo lugar: una ceremonia religiosa en la Academia Militar de Caracas, donde se administró al entonces presidente venezolano el sacramento de la unción de los enfermos a fin de contribuir "en su proceso de purificación", ${ }^{80}$ El 15 de julio, al cumplirse los 200 años de la Jura de los Poderes ante el Acta de la Independencia, se organizó un "Acto de Estado" destinado a que los poderes públicos del Estado reafirmaran su compromiso con la independencia del país. Días después, se dio inicio a los "IV Juegos del Bicentenario del ALBA", tuvo lugar el XIII Encuentro de la Secretaría Latinoamericana de Vivienda Popular (propuesta por el Movimiento de Pobladores) en el Teatro Teresa Carreño y se inauguró el Teatro Cristo Rey de la Parroquia 23 de Enero.

80 Palabras del monseñor Mario Moronta pronunciadas en Caracas, 12 de julio de 2011. Disponible en: https://www.aciprensa.com/noticias/obispo-administra-uncisn-de-los-enfermos-a-hugo-ch-vez 
El cronograma de actividades conmemorativas continuó el 24 de julio aniversario del natalicio de Bolívar- con la presentación del nuevo sarcófago donde se ubicaron los restos del héroe patrio, así como de un informe final con los hallazgos obtenidos luego de la exhumación de aquéllos. Por último, los festejos del bicentenario concluyeron el 30 de julio en el Paseo Los Próceres de Caracas con un desfile "histórico" denominado "Independencia para Siempre" - dirigido a representar los hitos principales de la historia venezolana- junto con un videomapping proyectado sobre los Monolitos del paseo en cuestión.

Por lo tanto, éstas fueron las seis propuestas conmemorativas desplegadas entre los años 2009 y 2011 por los Poderes Ejecutivos de Argentina, Bolivia, Ecuador y Venezuela durante sus respectivos bicentenarios de "independencia". El recorrido o, más bien, inventario aquí trazado -a la vez, descriptivo y disciplinado- de cómo aquellos primeros ensayos y aproximaciones dirigidos a urdir los regímenes conmemorativos del bicentenario se tradujeron, finalmente, en expresiones o productos concretos se verá, en los capítulos que siguen, desmontado y desgajado con el objetivo de identificar y ahondar en las continuidades, rupturas o desplazamientos de sentido que se suscitaron entre determinadas elaboraciones discursivas y ciertas prácticas festivas. No para juzgar la pureza o ausencia de ella en dichos acontecimientos, sino porque es el análisis de esa "densidad semántica" -al decir de Beatriz Sarlo-81 lo que posibilitará arrojar luz sobre las estrategias simbólicas, estéticas y de representación -en ocasiones contradictorias, ambiguas y/o azarosas- a las cuales acudieron estos gobiernos a fin de (re)plantear, por aquellos años, sus proyectos políticos e ideas de nación.

\footnotetext{
${ }^{81} \mathrm{Al}$ discurrir sobre sus modos de interpretar "lo urbano, lo social, lo político", Sarlo explicaba en una entrevista que, para ella, de lo que se trataba era de: "Tomar un acontecimiento y leerlo intensamente, como algo que puede ser muy pequeño, pero que tiene inmensa densidad semántica. Así es como uno lee una metáfora en un poema". Disponible en: https://elpais.com/elpais/2015/08/06/eps/ 1438878486 491624.html
} 


\section{Capítulo II}

\section{Los usos del pasado. Historias e identidades nacionales puestas a consideración}

Si bien pudiera resultar un lugar común -a la vez que una reiteración- señalar que los festejos del bicentenario devinieron ocasiones favorables para repensar la historia nacional con el objetivo de reactualizar ciertas identidades colectivas y legitimar ciertas posiciones en el presente, los "esfuerzos por ofrecer interpretaciones de algún segmento particularmente significativo del pasado, y por difundir una versión e imponerla a otras que compitan con ellas" (Cattaruzza, 2007: 17) merecen ser cuidadosamente examinados, al menos, por dos razones.

En primer lugar, porque el análisis de sus formas y contenidos permitirá dar cuenta de las filiaciones ideológicas a las cuales buscaron adscribir -de manera deliberada- los actores políticos que los motorizaron, pero también la persistencia o influencia -más bien automática, aleatoria y/o silenciosa- de otros lenguajes, tradiciones y modos de apelar y representar el pasado que, a la vez, limitaron y favorecieron, alternadamente, la eficacia de dichos empeños. En segundo lugar, porque -puestas en relación con el contexto particular en el que se desplegaron-el análisis de estas tentativas posibilitará, hacia el final de este estudio, echar luz sobre algunos rasgos, búsquedas y desafíos que, por aquellos años, parecían envolver las experiencias gubernamentales en cuestión.

I. Sobre la "primera" independencia y sus héroes 
En su estudio sobre los imaginarios de la república brasilera de fines de siglo XIX, José Murilo de Carvalho recuerda que "por ser en parte real, en parte construido, por ser fruto de un proceso de elaboración colectiva, el héroe nos dice menos acerca de sí mismo que sobre la sociedad que lo produce” (1997: 23). A esto se podría agregar que la producción o (re)creación de los "grandes hombres" de la independencia y las obras que se propusieron llevar a cabo se trata -como la de cualquier otro fragmento o figura del pasado- de una empresa siempre inconclusa, elástica y cambiante; susceptible, en fin, de múltiples (re)formulaciones en la medida que se encuentra estrechamente ligada a las transformaciones que cada sociedad experimenta en el tiempo.

En el caso de Bolivia, por comenzar por uno de los cuatro casos que analizaremos a lo largo de la tesis, los conflictos políticos y sociales que llevaron al gobierno central a inaugurar el "Bicentenario de los Pueblos 2009-2025" en El Villar sentaron las condiciones para una polémica y, en un primer momento, contundente reelaboración de las lecturas sobre el proceso de independencia, sus héroes y su status. "Por primera vez en la historia, en el municipio de El Villar se está festejando el aniversario de los doscientos años de unidad de los pueblos originarios para rendir homenaje a nuestros antepasados que lucharon por dejarnos una patria libre y soberana", se pronunciaba el alcalde del municipio, Modesto Claure, al dar la bienvenida a las distintas delegaciones indígenas y campesinas envueltas en banderas bolivianas, del MAS y wiphalas. ${ }^{82}$ La siguiente oradora, representante de la FUTPOCH, fue más allá al precisar que: "para las organizaciones, para quienes han luchado (...) para nosotros es más de quinientos años que ha sido la lucha, la revolución, y hoy en día se ve, también, (...) que estamos luchando". 83

Siguiendo esta línea, Morales recordó que

las primeras rebeliones han estado a la cabeza del movimiento indígena originario, no sólo en Bolivia, sino en Latinoamérica. La chispa la encendieron los indígenas (...) lamentablemente, las verdaderas luchas desde 1500, 1600 no son reconocidas,

\footnotetext{
82 Discurso pronunciado por Modesto Claure en El Villar, 25 de mayo de 2009. Disponible en: https:// www.youtube.com/watch?v=MjULyJhxGxA

83 Discurso pronunciado por Modesta Sifuentes en El Villar, 25 de mayo de 2009. Disponible en: https:// www.youtube.com/watch?v=MjULyJhxGxA
} 
ni recordadas ni escritas desde el colonialismo pasando por el imperialismo, liberalismo y neoliberalismo (...). ${ }^{84}$

En un intento por neutralizar el protagonismo de la ciudad y la participación criolla en la hazaña independentista, estos discursos terminaron de confirmar el "auténtico" objeto de la celebración, algo que la elección del lugar ya había anticipado: la versión canonizada de la Revolución de Chuquisaca se diluía para ceder su lugar a las rebeliones protagonizadas por los pueblos originarios desde la conquista hasta la actualidad, en donde la exaltación de la "Gran Rebelión andina" cobró especial relevancia. ${ }^{85}$

De modo que resultó natural que el panteón de los héroes también se viera reconsiderado. Antes que a los clásicos próceres criollos como Simón Bolívar y Antonio José de Sucre o Manuel Ascencio de Padilla, Jaime y Manuel de Zudáñez, José Bernardo Monteagudo y otros mestizos letrados de la Universidad San Francisco Xavier que participaron en la proclama del 25 de mayo de 1809, fueron exaltados, en cambio, "los líderes del movimiento indígena", es decir, el quechua Tomás Katari y el aymara Tupac Katari. "Hermanas y hermanos, el primer grito libertario ha sido acá en el año 1770 a la cabeza de Tomás Katari, después viene Tupaj Katari, después viene Juana Azurduy, después viene Simón Bolívar a garantizar esa liberación de nuestros pueblos”, afirmaba el presidente en la localidad de Ravelo tres días antes del aniversario patrio. 86

A su vez, este alejamiento de la narrativa criolla que persiguió la idea de una "nación sin indios" -esto es, aquella Bolivia blanca y moderna (Martínez, 2013a)condujo a que los tradicionales discursos androcéntricos se vieran, al menos en apariencia, matizados. Es que, como ha señalado la literatura sobre el tema, la figura de la mujer indígena-campesina en América Latina ha sido y continúa siendo fuertemente asociada a su rol dentro de la familia y el hogar y, en ese sentido, considerada de vital

\footnotetext{
84 Discurso pronunciado por Evo Morales en El Villar, 25 de mayo de 2009. Disponible en: https:// www.youtube.com/watch? $=$ n6arSuzaVn0\&NR $=1$

85 Se trata del violento proceso rebelde desatado entre 1780 y 1783 en el mundo andino, el cual estuvo protagonizado mayormente por indios comunitarios. Algunos de sus principales focos fueron-además de Cusco- La Paz y Chayanta. Sobre esta cuestión y las interpretaciones historiográficas relativas a ella, se sugiere la consulta de Vega (2017).

${ }^{86}$ Discurso pronunciado por Evo Morales en Ravelo, 22 de mayo de 2009. Disponible en: https:// www.youtube.com/watch? $v=11 \mathrm{~S} 1 \mathrm{tSSfEfw}$
} 
importancia al momento de preservar y reproducir la identidad del grupo; razón por la cual, se ha visto representada y enaltecida como símbolo y guardiana de la "auténtica" cultura indígena (de la Cadena, 1991; Crain, 2001; Ruiz, 2001).

En este caso, a la reivindicación de la heroína aymara Bartolina Sisa en tanto "madre de las madres anticolonialista y antiimperialista", 87 se sumó también la exaltación de la figura de Juana Azurduy de Padilla. ${ }^{88}$ Entre los representantes del cuerpo diplomático que habían llegado a El Villar, fue el embajador de Argentina el encargado de conmemorar el aniversario de muerte de la mestiza y subrayar su filiación al "ejército argentino" o, dejando a un lado los anhelos nacionalistas, al Ejército Auxiliar del Norte enviado desde Buenos Aires:

Venimos a recordar a los que murieron para que la patria viva y más aún, a recordar a la teniente coronel del ejército argentino Juana Azurduy de Padilla en un nuevo aniversario de su muerte (...) quien muriera el 25 de mayo de 1862 en el mayor silencio, en la mayor humildad y en la mayor pobreza digna de su valentía y digna de su honra (...). 89

${ }^{87}$ Disponible en: http://comunicacion.gob.bo/?q=20130823/12388

${ }^{88}$ En primer lugar, es preciso destacar que la apelación a dicha figura no resultaba una operación estrictamente novedosa en la historia boliviana. Caleb Wittum observaba que, previo al estallido de la Guerra Federal cuando el Partido Liberal continuaba creciendo y la irrupción de conflictos regionales se volvía cada vez más probable, las élites de Sucre -que habían enlazado su identidad regional al rol que Chuquisaca había tenido en la gesta independentista, lo cual les había permitido sostener que Sucre era el verdadero lugar de nacimiento de la nación boliviana- comenzaron a ampliar el panteón de los héroes, "incluyendo a mestizos como José Vicente Camargo y mujeres como Juana Azurduy a fin de obtener apoyos más amplios para su proyecto de construcción nacional” (2015: 2. Traducción mía).

Por otro lado y en cuanto al lugar que Azurduy guarda en la memoria histórica trazada por el gobierno del MAS, me interesa señalar que en el año 2007 se estableció por ley que todos los 12 de julio se celebrara el "Día de las Heroínas y Mártires de la independencia de América", en honor a la heroína nacida el 12 de julio de 1780. Asimismo y con vistas a la celebración bicentenaria, el gobierno instituyó en abril de 2009 el "Bono Juana Azurduy de Padilla", una asignación universal a embarazadas e hijos de menos de dos años de edad para paliar los problemas de desnutrición y mortalidad infantil y materna. Finalmente, en 2011 la exaltación de su figura llegaría a su punto cúlmine al ser ascendida al grado de "Mariscala del Estado Plurinacional" durante una sesión de honor de la Asamblea Legislativa Plurinacional que tuvo lugar en la Casa de la Libertad en la ciudad de Sucre en el marco de los festejos por el $186^{\circ}$ aniversario de la independencia de Bolivia.

89 Discurso pronunciado por Horacio Macedo en El Villar, 25 de mayo de 2009. Disponible en: https:// www.youtube.com/watch?v=MjULyJhxGxA

$\mathrm{Al}$ igual que en Bolivia, también es posible hallar un antecedente argentino en la reivindicación de la heroína en cuestión. En efecto, en mayo de 1938 un texto aparecido en la revista El Monitor de la Educación Común refería a Juana Azurduy de la siguiente manera: "Esposa ejemplar, inteligente y cultivada (...) poseía un gran criterio y una alta visión del provenir, siendo de este modo la mejor colaboradora de su esposo a quien admiraba y quería en forma absoluta. Su empeño en sostener a todo trance la causa de la revolución era motivo para que se preguntaran sus allegados en más de una ocasión, si habría abrazado ese anhelo por amor a su esposo o si era la idea que en ella predominaba; tan amalgamados estaban los dos sentimientos". El Monitor de la Educación Común, Año 57, número 785. Véase: http://www.bnm.me.gov.ar/giga1/monitor/monitor/785.pdf 
En esta pretensión por (re)presentar el mito de origen en clave inclusiva de modo que recogiera la participación de las mujeres, García Linera -además de destacar el papel de las "madres heroicas cochabambinas" que se enfrentaron al ejército realista en 1812-90 también se detuvo en la figura de la heroína altoperuana, insistiendo en su carácter de "madre heroína de todos los bolivianos":

Hace doscientos años, por estas montañas, por estos valles, por estos ríos de nuestra amada tierra cabalgaba la libertad de la mano de una mujer, de una madre heroína de todos los bolivianos y de toda América Latina. Esa chispa de hace doscientos años dio lugar a una (...) larga, cruenta guerra pero gloriosa guerra de emancipación de los bolivianos (...) por estas tierras cabalgó Juana Azurduy, una madre guerrillera, una madre comandante, una madre patriota que, espada en mano y caballo brioso iba liberando territorios no solamente de nuestra Chuquisaca sino que llegó a extenderse hasta llegar a Oruro, Potosí (...) Salta, Jujuy... por eso, el reconocimiento como una comandante de América Latina. Pero junto con ella, meses antes que ella, Zudáñez, Padilla. Y luego, después de ella, con ella, muchos otros patriotas, Muñecas en el norte de La Paz, Warnes en nuestra Santa Cruz, Esteban Arze en el valle, las madres heroicas cochabambinas (... $)^{91}$

De esta manera, fue el vicepresidente el encargado de introducir mayores matices a la lectura ofrecida por Morales. Luego de enaltecer el paisaje geográfico andino -en donde había nacido y luchado Azurduy, cuyo rol combativo pero también reproductivo había sido esencial en la "gloriosa guerra de emancipación de los bolivianos"-, García Linera restituyó e incorporó a la memoria histórica de la nación las figuras de otros caudillos criollos y mestizos, incluidos, Ildefonso de las Muñecas, sacerdote católico de La Paz quien lideró una de las guerrillas independentistas que combatió al ejército realista, así como Ignacio Warnes, militar porteño designado gobernador de Santa Cruz de la Sierra por Manuel Belgrano. Dos menciones particularmente sobresalientes en la medida que supusieron un guiño a la Iglesia católica, al mismo tiempo que remitían a la

\footnotetext{
90 Como reconocimiento a la actuación de este grupo de mujeres en la guerra de independencia de Cochabamba, Hernando Siles Reyes decretó en 1927 al 27 de mayo (fecha en la que tuvieron lugar los sucesos) como "día de la madre" en Bolivia.

91 Discurso pronunciado por Álvaro García Linera en El Villar, 25 de mayo de 2009. Disponible en: https://www.youtube.com/watch?v=khO6lqbNnYY
} 
reivindicación de uno de los héroes más venerados por el Movimiento Nación Camba de Liberación, es decir, la organización política que persigue la independencia del Departamento de Santa Cruz. ${ }^{92}$

Al reanudar su relato, García Linera argüía que

cuando en 1825 se funda la patria (...) los caudillos indios habían sido exterminados, los caudillos mestizos habían perecido (...) ¿quiénes quedaban? Los dos caras, los doctores dos caras, realistas opresores el día de ayer convertidos en un solo día en patriotas. La patria nació sobre el esfuerzo y la lucha de millones de indígenas y mestizos, de criollos, de la ciudad y el campo pero que cuando culminaba su trabajo no estaban ellos para levantar con sus propias manos las nuevas instituciones. La victoria era del pueblo, la conducción era de los mismos de antes. Y por eso cuando nació Bolivia no... no se conquista la igualdad. Cuando nace nuestra patria habrán los ciudadanos con derechos políticos para gobernar y habrán el resto de bolivianos, sin derechos políticos, es decir, los indios, los trabajadores, los artesanos $(\ldots)^{93}$

Por consiguiente y a diferencia del elogio a la "Gran Rebelión andina" efectuado por el primer mandatario, el relato tramado por el vicepresidente adquiría un tinte más abarcativo al remarcar la unión entre la participación indígena y el accionar mestizo y criollo -tanto femenino como masculino-, el elemento campesino y el urbano y, finalmente, la actuación civil, militar y eclesiástica, postulando la idea de una independencia inconclusa debido al accionar de los "dos caras", el verdadero enemigo de la nación que, cuando ésta "nacía", se hizo del poder político a costa de la gesta popular.

Cercanas a esta perspectiva, las lecturas sobre el pasado nacional llevadas a cabo por el primer mandatario boliviano en el marco de la celebración del bicentenario de la

\footnotetext{
92 Las siguientes palabras de la Unión Juvenil Cruceñista son una clara muestra del lugar otorgado a Warnes en su reconstrucción de la historia e identidad cruceña: "Durante casi tres siglos de colonia Santa Cruz se desarrolló, defendió y subsistió por su propio esfuerzo, proveyéndose de los medios necesarios mediante la producción agrícola, ganadera e industrial. Nunca recibió una migaja de la plata de Potosí; comerció para ganarse sus recursos. El 24 de Septiembre de 1810 los cruceños se alzaron en armas, derrotando al subdelegado Pedro Toledo. Querían convocar a un cabildo y organizar su propio gobierno. Aunque el movimiento -encabezado por los insurgentes Ignacio Warnes, José Manuel Mercado, José Manuel Baca y otros- fue derrotado, constituyó un hito y un referente histórico libertario". Disponible en: http://razaynacioncamba.blogspot.com/2007/08/union-juvenil-cruceista.html
}

93 Discurso pronunciado por Álvaro García Linera en El Villar, 25 de mayo de 2009. Disponible en: https://www.youtube.com/watch?v=khO6lqbNnYY 
Primera Junta Tuitiva de Gobierno en julio de 2009 experimentaron un leve giro respecto al modo en que éste había decidido reconstruir y representar la memoria histórica de la nación meses atrás. En efecto, al volver sobre los orígenes de Bolivia, Morales observaba:

Tantos líderes que han dado su vida por nosotros y es nuestra obligación como hijos de Tupac Katari, como nietos y bisnietos de Bartolina Sisa, dar nuestros homenaje a esos hombres que dieron su vida, como Pedro Domingo Murillo, tantos en el Chaco, en Cochabamba, en Santa Cruz (...) civiles e indígenas (...) pero también militares $(\ldots)^{94}$

a [los] héroes que hace 200 años atrás decidieron acabar con el poder colonial; mestizos y originarios quienes lucharon por la independencia y derechos de este país, quienes también lucharon por un nuevo estado y hoy seguimos la lucha buscando la igualdad de todos los bolivianos y bolivianas, de todos los latinoamericanos. En el año 1809 Pedro Murillo y un grupo de mestizos se levantaron contra el poder colonial e instauraron un nuevo gobierno. Un poco antes se levantaron en Sucre y Chuquisaca pero ese levantamiento viene en una lucha permanente del movimiento indígena originario $(\ldots)^{95}$

Además de llamar la atención sobre la participación de otras geografías del país en la gesta de independencia -específicamente, el sur y el oriente del mismo-, el presidente no solo procuró destacar el carácter indígena, civil y militar de los líderes de la revolución, sino también delinear una representación indígena-mestiza de los orígenes de la nación al enlazar las figuras pioneras de Pedro Murillo -héroe criollo y mestizo del levantamiento del 16 de julio de 1809- y la de Tupac Katari -héroe aymara de las rebeliones de 1781-, para la cual debió hacer a un lado el incómodo detalle de

\footnotetext{
94 Discurso pronunciado por Evo Morales en Patacamaya, 13 de julio de 2009. Disponible en: $\underline{\text { https:// }}$ www.youtube.com/watch? $\mathrm{v}=\mathrm{ZG} \operatorname{lm} 64 \mathrm{C}-\mathrm{NJ} 0$

95 Discurso pronunciado por Evo Morales en La Paz, 16 de julio de 2009. Disponible en: http:// www.cubadebate.cu/especiales/2009/07/16/declaraciones-del-presidente-de-bolivia-evo-morales-en-losactos-por-la-celebracion-del-bicentenario-del-grito-libertario-video/\#.V2BGx5HhCM8
} 
que habría sido, justamente, el primero parte de las tropas realistas que reprimieron los asedios a La Paz comandados por el segundo. ${ }^{96}$

Por lo tanto, la interpretación de la empresa independentista ofrecida por el gobierno del MAS osciló, durante las celebraciones bicentenarias, entre una abierta exaltación de la "Gran Rebelión andina" -lo cual habilitó la afirmación de los Andes como epicentro de la revolución y origen de la nación, así como de los pueblos y héroes aymara y quechua como sus auténticos precursores- y cierto intento por matizar ese énfasis al recuperar las interpretaciones clásicas de la independencia y admitir -aunque siempre destacando el carácter inaugural de la primera- la identidad mestiza y criolla al igual que la geografía no andina como rasgos también constitutivos del proceso independentista y, como consecuencia, de la nación.

En sintonía con esta tentativa por restaurar el panteón nacional y el mito de origen boliviano, en la lectura sobre la independencia efectuada por el gobierno de la Revolución Ciudadana en las vísperas del bicentenario de la Primera Junta de Gobierno de Quito también es posible identificar un aparente distanciamiento respecto de la historiografía tradicional decimonónica y la reposición del rol de los sectores subalternos en las luchas emancipadoras. Efectivamente, para Correa, la memoria de "hombres y mujeres insurrectos que jamás aceptaron la esclavitud, gente común, de a pie, los indios, los mestizos, los blancos, los mulatos, los cobrizos, los cholos, los negros, los variopintos, con un solo color libérrimo en el alma: la libertad (...)"97 era una tarea fundamental, siendo su recuerdo lo único que posibilitaba -según el mandatario- "herir de muerte al olvido" ya que "desde el 10 de Agosto de 1809 hasta el 24 de Mayo de 1822 ocurrió, ante todo, una gesta popular". 98

\footnotetext{
${ }^{96}$ María Saenz Quesada señalaba que "El propio Murillo, protomártir del alzamiento de 1809, había formado parte del ejército virreinal que levantó el sitio de La Paz, asediada por las fuerzas de Tupac Catari”. La Nación, 29 de julio de 2009. Disponible en: https://www.lanacion.com.ar/1155918-el-dialogocon-la-historia

Aún más, para el escritor aymara Germán Choque Condori ("Kara Chikiwanka") (2004), Murillo no solo habría actuado en favor del rey de España frente al levantamiento indígena ocurrido en 1781, sino que también se habría visto directamente involucrado en el asesinato y descuartizamiento del héroe aymara.

97 Discurso pronunciado por Rafael Correa en Quito, 24 de mayo de 2009. Disponible en: http:// www.presidencia.gob.ec/wp-content/uploads/downloads/2013/12/2009-05-24-BATALLA-DELPICHINCHA.pdf
}

98 Discurso pronunciado por Rafael Correa en Quito, 10 de agosto de 2009. Disponible en $<\underline{\mathrm{http}: / /}$ www.presidencia.gob.ec/wp-content/uploads/downloads/2013/10/10-10-09-

Discurso_posesion_Presidencial.pdf $>$ 
Durante la toma de posesión simbólica del mando presidencial a través de un ritual indígena, el entonces ministro de Cultura y Patrimonio, Ramiro Noriega, expresaba, a su vez, "que los 200 años de independencia no son para nosotros dos siglos de lucha, son por lo menos 500 años de resistencia". 99 En consecuencia, si bien los sucesos de 1809 fueron fundamentales para alcanzar "la meta soñada de la libertad",100 las rebeliones indígenas en contra de la dominación española habrían sido las encargadas de inaugurar la lucha libertaria:

Durante todo este tiempo, y aún antes, desde la insurgencia de los Barrios de Quito y las memorables rebeliones indígenas del siglo XVIII, junto a los criollos se encontraron los mestizos, los indios, el cholerío numeroso; los artesanos (...) las mujeres (...) las guarichas, sobre todo las inolvidables y aguerridas guarichas $(\ldots) .{ }^{101}$

Ahora bien, esta reconfiguración narrativa que postulaba al pueblo como pilar de la hazaña independentista -e, incluso, destacaba el carácter precursor de la rebelión anti-fiscal de 1765 conocida como la "Revolución de los Estancos", así como los levantamientos indígenas de finales del siglo XVIII- no supuso una condena al caudillismo liberal ni el desplazamiento de éste a un lugar secundario o subsidiario de la "gesta popular". Al contrario, los "héroes de bronce" se mantuvieron en el podio de la memoria histórica ecuatoriana, sirviendo de fundamento, origen e inspiración a la RC. En palabras de Correa:

De nuestros primeros patriotas, de los Espejo y los Mejía, de los Olmedo y Rocafuerte, de los Montúfar y Morales, de los Salinas y Quiroga, de los Riofrío, Villalobos, Manuela Cañizares, recogemos la bandera de la soberanía y la

\footnotetext{
99 El Ciudadano, 9 de agosto de 2009. Disponible en: http://presidencia.informatica.gob.ec/index.php?option=com content\&view=article\&id=4691:ministrode-cultura-otorgo-a-evo-morales-y-rigoberta-menchu-la-medalla-bicentenario\&catid=1:archivo (último acceso 17/04/2016). Puede verse también: http://www2.latercera.com/noticia/ecuador-condecora-a-evomorales-y-rigoberta-menchu/

100 Discurso pronunciado por Rafael Correa en Quito, 10 de agosto de 2009. Disponible en $<\underline{\text { http:// }}$ www.presidencia.gob.ec/wp-content/uploads/downloads/2013/10/10-10-09Discurso_posesion_Presidencial.pdf $>$

101 Ibídem. Por guarichas, se refiere al conjunto de mujeres ignotas que acompañaron a los soldados y fueron parte del ejército libertador.
} 
autodeterminación que ellos valientemente levantaron con sus escritos, con su oratoria, con el primer gobierno de agosto de 1809.102

Sucre, quien amó a esta Patria nuestra hasta el punto de pedir ser enterrado en nuestro suelo, tuvo la clarividencia de defender la industria nacional, el derecho de nuestro país al desarrollo de su manufactura (...) ¿Qué tal si desde entonces hubiéramos perseverado en la integración y en la colaboración, en vez de la 'competencia' entre latinoamericanos? Hoy, a casi 200 años, el sueño de Bolívar está camino de cumplirse. ¡No vamos a fallarte, Libertador! 103

Por lo tanto y a diferencia de las oscilaciones señaladas para el caso boliviano, la revisión de la memoria histórica realizada por el Poder Ejecutivo ecuatoriano no solo descartó la posibilidad de establecer jerarquías, sino que postuló desde un comienzo una doble reivindicación, criolla y popular, que pretendió escapar a la dicotomía "patria de criollos"/“"patria de indios, negros y castas"; lo cual lo obligó a diluir la divergencia de intereses económicos, políticos y regionales que atravesaron al proceso independentista y, en particular, a las élites políticas de la época (Rodríguez, 2006).

Otro ejemplo de ello se pudo observar en los escenarios montados en las plazas de Quito durante la "velada libertaria" del 9 de agosto, donde un conjunto de actores evocaron a figuras involucradas en los levantamientos indígenas o en la gesta independentista: Antonio José de Sucre y Mariana Carcelén; Rumiñahui y Tupac Amaru; Simón Bolívar y Manuela Sáenz; Rosa Zárate y Rosa Campuzano; Manuela Cañizares y Manuela Espejo; Manuel Rodríguez Quiroga y Juan de Dios Morales; Francisco Calderón y Abdón Calderón; Carlos Montúfar y Juan Pío Montúfar; Juan José de Salinas y Zenitagoya; y Eugenio Espejo, José Mejía y José Joaquín de Olmedo.

En este sentido, la reivindicación de Francisco Calderón y Abdón Calderón -de procedencia cuenqueña- y de "los Olmedo y Rocafuerte" -en alusión a José Joaquín de Olmedo y Vicente Rocafuerte, dos figuras prominentes de la guerra de independencia encabezada, a partir de 1820, desde la provincia de Guayaquil- denota el intento del presidente por integrar próceres oriundos de otras regiones a la memoria histórica de la

\footnotetext{
102 Ibídem.

103 Discurso pronunciado por Rafael Correa en Quito, 24 de mayo de 2009. Disponible en: http:// www.presidencia.gob.ec/wp-content/uploads/downloads/2013/12/2009-05-24-BATALLA-DELPICHINCHA.pdf
} 
nación y a la celebración del bicentenario de la revolución de Quito, incluso cuando - $\mathrm{O}$ pese a que- algunos de ellos hubieran representado la postura fidelista de la ciudad que se opuso al movimiento quiteño desatado entre 1809 y 1812 (Rodríguez, 2004).

Otro actor que también apareció en la reconstrucción oficial del proceso de independencia ecuatoriano fue la Iglesia católica. Es así que, al hacer referencia a los "primeros patriotas", fue reivindicada la figura de una Iglesia comprometida con la causa libertaria, cuyo principal exponente habría sido el cura José Luis Riofrío, de origen humilde, identificado con las causas populares, misionero en la zona amazónica -al igual que el entonces presidente- y capellán de las tropas criollas. En este sentido, la reposición del papel de una parte del clero durante la crisis monárquica y la notoria ausencia de José de Cuero y Caicedo -obispo, vicepresidente de la Primera Junta y (único) presidente del Estado Independiente de Quito- en esa enumeración de héroes y heroínas de la independencia podría leerse en relación al afán de Correa -asunto que retomaré más adelante- por distanciarse de la cúpula eclesiástica aunque sin que ello suponga una ruptura con la totalidad de la institución. ${ }^{104}$

Al igual que en el caso boliviano, la distinción del accionar revolucionario femenino devino otro de los rasgos distintivos de los discursos conmemorativos del gobierno de la RC. Así, mujeres "extraordinarias" como las "Manuelitas" (Espejo, Cañizares y Sáenz Aizpuru), Rosa Campuzano, Rosa Zárate, Mariana Carcelén y Rosa de Montúfar junto a las guarichas fueron exhibidas, aunque con intensidades y protagonismos diversos, en tanto actores fundamentales de la historia independentista ecuatoriana: 105

\footnotetext{
104 Cabe acotar que, tras el bicentenario del fallecimiento de José de Cuero y Caicedo, el 12 de septiembre de 2016 tuvo lugar la ceremonia de repatriación de sus restos gestionada por el Ministerio de Cultura y Patrimonio y la Academia Nacional de Historia. Trasladados desde Lima a Guayaquil y desde ésta a Quito, éstos fueron colocados -luego de una ceremonia en la Plaza Grande y una misa conmemorativa que no contó con la presencia de Correa- en la Catedral Metropolitana de Quito junto a los restos de Sucre y Carlos Montúfar.

105 La exaltación del papel femenino en la empresa libertadora tampoco resulta, para este caso, una novedad. De hecho, María José Vilalta recuerda que "En la declaración de la independencia de la ciudad de Quito del 10 de agosto de 1809, ninguna mujer firmó el documento inicial, puesto que no formaban parte del estamento de los diputados del pueblo agrupados por barrios. Años más tarde, cuando se procede a una reconstrucción de la memoria en la conmemoración del primer centenario de aquellos hechos, a través del encargo, construcción y emplazamiento del monumento a los héroes sito en la plaza de la Independencia, nadie consideró inadecuado que, entre más de cuarenta próceres de la revolución, apareciera inscrito el nombre de la instigadora, organizadora y activista Manuela Cañizares (Guzmán Polanco 2006)" (2012: 63).
} 
La historia del Ecuador, contada desde el poder, ignoró a Manuela, como ignoró a tantas mujeres que consagraron su talento a construir un país distinto. Conspiradoras, como Manuela Cañizares, Manuela Espejo y Rosita Campuzano; combatientes disfrazadas de soldados, como Nicolasa Jurado, Inés Jiménez y Gertrudis Esparza, luchadoras en Pichincha y Ayacucho (...) fueron todas, en su momento, vilipendiadas por poseer tres características: ser independentistas, ser soberanas y ser mujeres. ${ }^{106}$

Particularmente interesante resulta el modo en que Correa restituyó y enfatizó la memoria -“confiscada por tanto tiempo"- de la heroína criolla Manuela Sáenz Aizpuru, quien en 2007 había sido ascendida a Generala del Ejército ecuatoriano:

Muchas veces han tratado de ocultarnos, de falsificarnos la memoria de Manuela Sáenz como luchadora, como pasionaria de la libertad; mujer consecuente con sus ideales, excepcional en la valentía y en la devoción a los ideales bolivarianos. Mucho de Manuela ha venido hasta aquí, sobre todo su memoria llena de insurrección, su manera de asumir el futuro [...] ella siempre tuvo una mirada continental, integracionista, libertaria, que buscaba la unidad de los pueblos [...], cobijados bajo el ideal de una América unida, libre y soberana. ${ }^{107}$

La joven bella y desenvuelta era relámpago refulgente de los salones quiteños, en donde el duelo entre patriotas y españoles se libraba al compás de minués y contradanzas; ella, la indomable, entregó desde el principio su vida y su talento a la rebelión, y la llevó hasta su extrema consecuencia, vistiendo uniforme militar y combatiendo en los campos de batalla, conspirando en la sombra cuando fue necesario, e inspirando a Bolívar en la adopción de audaces decisiones. 108

La apelación a quien fue compañera de Bolívar -y aquí queda el interrogante de cuánto de este énfasis conmemorativo en la figura de Sáenz Aizpuru no es deudor de la

\footnotetext{
106 Discurso pronunciado por Rafael Correa en Quito, 6 de agosto de 2007. Disponible en: https:// www.cepal.org/sites/default/files/presentations/discursopresidenteecuador_0.pdf

107 Discurso pronunciado por Rafael Correa en Caracas, 5 de julio de 2010. Disponible en: https:// www.presidencia.gob.ec/wp-content/uploads/downloads/2014/01/DISCURSO-EN-HOMENAJE-AMANUELA-SÁENZ-AIZPURU.pdf
}

108 Discurso pronunciado por Rafael Correa en Buenos Aires, 3 de noviembre de 2010. Disponible en: https://www.presidencia.gob.ec/wp-content/uploads/downloads/2012/10/031210_Desvelizamiento-delBusto-de-Manuela-Saenz.pdf 
historiografía tradicional que la recordaba por haber sido "la Libertadora del Libertador"-109 tuvo como finalidad moderar los clásicos discursos que celebraban exclusivamente las notables acciones de (algunos) líderes masculinos de la independencia, exhibiéndolos como únicos agentes de dicho proceso histórico.

Ahora bien, la reivindicación de una idea de mujer combativa, política y estratega no supuso ningún conflicto con su simultánea asimilación a la reproducción y la maternidad. De esta manera, Correa postulaba -como García Linera lo había hecho con la figura de Juana Azurduy- una afinidad natural entre la "mujer-política" y la "mujerreproductora":

El reconocimiento a la memoria de Manuela Sáenz y Rosita Montúfar se traduce en la mejora salarial de las madres y mujeres que realizan trabajo doméstico; se traduce en la tranquilidad de las madres de escasos recursos que pueden enviar a sus hijos a la escuela sin pensar en onerosas "contribuciones voluntarias"; que saben que sus hijos cuentan con uniformes y útiles gratuitos, con desayuno escolar, con unidades educativas ejemplares (...) se traduce en las madres de hijos con discapacidad que están siendo atendidas y protegidas con ayudas técnicas y otras contribuciones $(\ldots)^{110}$

De modo que el Poder Ejecutivo ecuatoriano trazó una interpretación del proceso de independencia que, sin pretensiones de trastocar el clásico panteón nacional, buscó ampliarlo y conjugarlo -en una suerte de síntesis superadora capaz de disimular las contradicciones- con otras figuras, identidades o sujetos considerados marginales a fin de plantear una representación plural y conciliadora de los orígenes de la nación ecuatoriana; origen fiduciario de las rebeliones indígenas pero cuyo puntapié inicial lo

\footnotetext{
109 Como advertía Londoño López: “a lo largo del XX la mayoría de los historiadores resaltaron, fundamentalmente, su belleza, su inteligencia y su generosidad en el amor. Asimismo destacaron su perfil de amante de uno de los más importantes héroes americanos, Simón Bolívar. (...) En aquella historiografía (...) Manuela era únicamente la mujer que, en un acto de valentía, un 25 de septiembre en Bogotá, salvó a su amado de un vil asesinato. Acto por el cual se la conoció con el apelativo de 'la Libertadora del Libertador', que el mismo Bolívar le dio en aquella ocasión” (2008: 67). Conviene recordar que es, justamente, este mismo tipo de lectura el que se halla en la nota sobre Juana Azurduy publicada en 1938 en Buenos Aires por El Monitor de la Educación Común.

110 Discurso pronunciado por Rafael Correa en Quito, 24 de mayo de 2010. Disponible en: https:// www.presidencia.gob.ec/wp-content/uploads/downloads/2014/01/24-05-10-Discurso-del-VicepresidenteLM-por-conmemoracion-victoria-Pichincha-y-homenaje-Gnrl.-Manuela-Saenz.pdf
} 
habrían dado los -múltiples- actores involucrados en los sucesos de agosto de 1809 en Quito.

En Argentina, la reconstrucción oficial del período de la independencia ratificó, al igual que el Poder Ejecutivo ecuatoriano, las proezas de los grandes héroes y los sucesos militares y/o políticos que la historia liberal se había propuesto consolidar hacia finales del siglo XIX. De hecho, que el videomapping proyectado sobre el Cabildo iniciara nada más ni nada menos que con los enfrentamientos ocurridos en el Virreinato del Río de La Plata entre las milicias urbanas y las fuerzas inglesas en 1806 y 1807 declarados en el 2006 "precedentes del pronunciamiento de mayo de 1810 "-,111 deja ver cómo el relato de la nación trazado en y para esta puesta en escena continuaba enmarcado dentro de las periodización clásica de aquella corriente historiográfica, para la cual las invasiones inglesas habían sido las responsables de sembrar la idea de libertad entre los porteños, sirviendo de antesala a la revolución.

En esta línea, no resulta llamativo que entre los héroes de la independencia destacados en el videomapping, en la publicidad oficial del bicentenario y/o en la "Galería de los Patriotas Latinoamericanos" se encontraran José de San Martín, Mariano Moreno, Manuel Belgrano o Juan José Castelli. Ahora bien, en un intento por matizar las "historias edulcoradas de esas jornadas gloriosas"112 - es decir, ciertas lecturas de inspiración liberal o "mitrista" que las habrían presentado, a ojos de Fernández de Kirchner, como mesuradas reuniones de vecinos respetables-, esta última

\footnotetext{
111 Decreto $N^{\circ} 1129$ del 16 de mayo de 2006. Disponible en: http:/www.gob.gba.gov.ar/legislacion/ legislacion/06-1129.html

112 Discurso pronunciado por Cristina Fernández de Kirchner en Buenos Aires, 25 de mayo de 2010. Disponible en: https://www.perfil.com/noticias/politica/el-discurso-completo-de-cristina-kirchner-por-elbicentenario-20100525-0038.phtml
} 
explicaba, en clave notablemente revisionista, ${ }^{113}$ que las jornadas de Mayo no habían sido "tan pacíficas, no fueron consensuadas, fueron de hombres y mujeres, de un Castelli, que furibundo ingresó a ese Cabildo el 22 de mayo a decir que si no conformaban el gobierno patrio iban a venir con las armas y los iban a venir a conformar ellos [Castelli y allegados]". 114

Tiempo después, en otro aniversario de la Revolución, la entonces mandataria volvería a arremeter contra la historia "oficial" al añadir no solo a otros actores siempre masculinos- al panteón nacional, sino también al sugerir que la revolución no había sido antihispánica:

\begin{abstract}
Yo (...) quiero recordar estos 203 años de nuestra Revolución de Mayo, pero no hacerlo desde la versión anodina y aséptica que muchas veces nos explicaron.

Yo quiero recordar y veo en todos ustedes, en esas caras jóvenes, las caras de otros jóvenes, de French, de Beruti, de Moreno, de Monteagudo los verdaderos cerebros de esa revolución, French y Beruti que no repartían como nos enseñaron en el Billiken, escarapelas festejando la caída del virrey. Repartían escarapelas que en
\end{abstract}

\footnotetext{
113 Según Halperín Donghi, el revisionismo histórico argentino vino a confrontar e impugnar el carácter "armónico" y "optimista" de las interpretaciones sobre el pasado nacional arrojadas por la historiografía tradicional, así como las "apacibles seguridades" sobre las cuales ésta descansaba. Es así que, frente a esa imagen afable de la historia argentina, la versión revisionista habría intentado -con "demasiado evidentes insuficiencias"- recuperar ciertas "perplejidades" del pasado nacional "silenciadas" por aquella corriente historiográfica, especialmente, en lo que a la Argentina postrevolucionaria atañía: “(...) luego de la crisis final de una Argentina que había confiado en un futuro de creciente prosperidad sobre las líneas de avance trazadas a mediados del siglo XIX, y había elaborado una imagen de ese pasado adecuada a ese futuro en el que ya no era posible creer, la tarea de proponer a la nación una imagen alternativa de ese pasado, que permitiera entender mejor las duras alternativas del presente y ofreciera inspiración para resolverlas, fue encarada por un grupo cuya fe en el valor de la historia como reveladora de los rasgos básicos de la realidad nacional no siempre iba acompañada de la ambición de entender históricamente el pasado" (1970: 91-92).

Ahora bien y a la luz de ciertos escritos posteriores que propusieron algunas consideraciones y matices sobre la cuestión, es posible sostener que "no solo otros historiadores, incluyendo a miembros de la 'nueva escuela', habían reclamado con mucha anterioridad a los años treinta la revisión de las visiones disponibles del pasado nacional, sino que otros grupos culturales habían acuñado piezas del que luego sería el arsenal del revisionismo; algunos revisionistas, a su vez, admitían estas circunstancias. Sin embargo, ese reconocimiento parcial pasó desapercibido en la coyuntura de la Segunda Guerra Mundial, y fue la imagen de una 'historia oficial' monolítica, que constituyó parte de la vulgata revisionista, la que persistió. De esta manera, la evocación o el 'olvido' de los anticipos vuelven a transformarse en operaciones que el revisionismo desarrollaba para inventar su combate originario y posicionarse en él (...) así, la invención y la difusión de la imagen que planteaba la existencia de una lucha entre la 'historia oficial', un bloque sin fisuras, y sus impugnadores, otro conjunto que se pretendía uniforme, fue quizás el triunfo más importante del primer revisionismo" (Cattaruzza, 2003: 6; 11-12).

Efectuadas estas observaciones, véase sobre el revisionismo histórico argentino en sus diferentes versiones y los debates surgidos en torno a él: Halperín Donghi (1970, 2005b); Quattrocchi-Woisson (1995); Chiaramonte (2001); Cattaruzza (2003); Goebel (2013).
}

114 Discurso pronunciado por Cristina Fernández de Kirchner en Buenos Aires, 25 de mayo de 2010. Disponible en: https://www.perfil.com/noticias/politica/el-discurso-completo-de-cristina-kirchner-por-elbicentenario-20100525-0038.phtml 
realidad eran cintas amarillas españolas marcando los que únicamente podían ingresar al Cabildo. Así se hizo la Revolución de Mayo (...)

Jóvenes con ideales también junto a nuestros hombres de armas, encabezados por Cornelio Saavedra, el Regimiento de Patricios, que eran las épocas fundacionales del país donde pueblo y fuerzas armadas, las ideas junto a los que empuñaban también las armas para defender esa gran patria que nacía, construían la historia. ${ }^{115}$

Procurando escapar a las interpretaciones "edulcoradas" pero haciendo a un lado las fisuras, tensiones y rivalidades que irrumpieron al interior del proceso rioplatense (Halperín Donghi, 2005), el Poder Ejecutivo argentino lo presentaba, entonces, como una gesta intelectual a la vez que militar, protagonizada por el "pueblo" y las "fuerzas armadas" aunque conducida, a fin de cuentas, por un grupo de individuos particulares, de origen criollo, letrados y militares, que aún no festejaban "la caída del virrey" mas defendían "la patria que nacía".

Es así que en esta visión consensual de la historia nacional, muy cerca de las figuras sobresalientes de Buenos Aires, despuntaba - ¿haciendo quizás resonar a lo lejos

115 Discurso pronunciado por Cristina Fernández de Kirchner en Buenos Aires, 25 de mayo de 2013. Disponible en: https://www.cfkargentina.com/203o-aniversario-de-la-revolucion-de-mayo-decadaganada/ 
cierta tradición federal de raigambre católico-conservadora?-116 el potosino Cornelio

Saavedra, quien, de hecho, ya había aparecido, junto a Moreno y Belgrano, al inicio del

videomapping del bicentenario. ${ }^{117}$ De igual modo, se sumaban otras personalidades del

116 Distintos intelectuales, muchos de ellos provenientes del ensayo político, se han visto, al calor de las disputas políticas de turno, particularmente interesados en el enfrentamiento entre Cornelio Saavedra exhibido como exponente, junto con el Deán Funes, de la tendencia moderada de la Revolución-y Mariano Moreno - caracterizado como el máximo representante del liberalismo o, aun, jacobinismo porteño-. Entre ellos, cabe destacar las voces procedentes del revisionismo nacionalista de corte elitista, las cuales sostuvieron que la tradición católica, hispanista, federal y nacionalista en Argentina se remontaba a la figura del "militar" y "conservador" Cornelio Saavedra. En efecto, autores como Julio Irazusta, Carlos y Federico Ibarguren o Gustavo Martínez Zuviría filiaban y exaltaban -en su búsqueda por restaurar la tradición católica e hispana quebrantada por el liberalismo- a Saavedra y Rosas en oposición a Moreno. Federico Ibarguren incluso sostenía, en Orígenes del nacionalismo argentino 1927-1937, que la "tradición hispano-federal" constituía el fundamento del nacionalismo argentino (1969: 13).

Elementos de esta tradición antiliberal (aunados a otros propios de la vertiente popular del "rosismo" representada principalmente por José María Rosa, quien también reivindicó a Saavedra en detrimento de Moreno por haber conseguido el apoyo del pueblo) tendrían un fuerte impacto en la obra y pensamiento de un exponente del llamado "neorevisionismo" estrechamente ligado a los gobiernos kirchneristas, Mario O'Donnell (2014), quien, de hecho, sostenía en uno de sus tantos escritos que "El 'morenismo' protounitario decidió el nacimiento de la Sociedad Patriótica en marzo de 1811 y conspiró abiertamente en contra de Saavedra (...) Sorpresivamente, en la medianoche del 5 de abril de 1811 la ciudad asistió atónita al espectáculo de riadas de gauchos, indios, mulatos, orilleros, que venían de la campaña y de los suburbios plebeyos de la ciudad y que ocuparon la plaza de la Victoria en apoyo Saavedra y los suyos. Fue una reacción espontánea del pueblo humilde contra las 'gentes de posibles' y los jóvenes 'alumbrados' de la Sociedad Patriótica por considerar que pretendían dar a la Revolución un sesgo elitista y extranjerizante que no comprendían y tampoco compartían”. Disponible en: https:// books.google.com.ar/books?

$\mathrm{id}=$ BjGQAwAAQBAJ\&pg $=\mathrm{PT} 49 \& \mathrm{hl}=\mathrm{es} \&$ source $=\mathrm{gbs}$ toc $\mathrm{r} \& \mathrm{cad}=2 \# \mathrm{v}=$ onepage $\& \mathrm{q} \& \mathrm{f}=$ false De igual modo, Andreas Doeswijk recuerda que en las visiones del mencionado autor "para el saavedrismo todo son elogios: 'Un bando más apegado a las tradiciones hispánicas y cristianas, provincianista, próximo a la chusma del puerto y del interior. [...] Con lógicas salvedades se puede hablar de la anticipación del federalismo.' Lo que O’Donnell le reprocha con insistencia a los alumbrados es su 'desconfianza a lo telúrico y su amor a lo europeo' y que leyeran a Rousseau y Payne. (...) Una de las claves escriturarias del autor es la de trazar la línea genealógica del proyecto nacional, federal y antiimperialista desde Mayo a la actualidad. Esta línea no se sustenta en evidencias empíricas documentales. En una entrevista que le realizó, en marzo de 2008, el periodista Eduardo Nocera, el escritor, una vez más, enfatiza esa línea genealógica que atravesaría la historia argentina: 'O sea que en Moreno ya se ve algo de esa rémora de europeísmo que luego será exacerbado por Rivadavia y los vencedores de las guerras civiles, la generación del 80, que han llevado a esta deformación profunda de la identidad nacional que pretende constituirse desde un espejo europeísta, dejando de lado absolutamente a todo lo que es criollo e hispánico"” (2010: 21).

A su vez y al calor del bicentenario de Mayo, O’Donnell elegiría a los "diez representantes" que mejor simbolizaban "los 200 años de historia", entre los cuales incluiría al presidente de la Primera Junta de Gobierno, "a quien nuestra historia oficial maltrata, que a diferencia de Moreno - que tenía una idea de que debía haber una vanguardia esclarecida que llevara adelante la revolución-, Saavedra se inclinaba por la participación de los sectores populares, como fue evidente al fomentar el ingreso de los representantes provinciales en la junta de mayo constituyendo la Junta Grande. Podría decir que Moreno fue protounitario y Saavedra protofederal". Disponible en: https://nomequieroolvidar.wordpress.com/ 2010/05/24/los-10-destacados-de-la-historia/

117 Conviene recordar que lo ocurrido en este caso tampoco fue una innovación. Como recuerda Cattaruzza al discurrir sobre las conmemoraciones del centenario de la Revolución de Mayo, "en ese mapa de los lazos con el pasado que constituyen los monumentos a los próceres, por ejemplo, se hacía visible la tendencia de la evocación de 1910 a volver uno lo que había sido diverso (...): en mayo de aquel año se inauguraba la estatua de Cornelio Saavedra; en octubre, la de Mariano Moreno. Dos de los dirigentes centrales de la Revolución, que a pesar de haber estado enfrentados en su hora, eran homenajeados en el mismo movimiento" (2007: 34-35). 
interior, como el tucumano Bernardo de Monteagudo -distinguido, muy probablemente, por sus radicales ideas democráticas sostenidas en los tiempos de las luchas emancipadoras- o, incluso, el salteño Martín Miguel de Güemes, el cual -acaso por su habitual ligazón a lo "federal" y "popular"- fue reivindicado en diferentes ocasiones como otro "de los grandes de la patria". 118

El panteón de héroes masculinos criollos fue acompañado, asimismo, de algunos intentos por subrayar la participación de los sectores subalternos en las guerras de independencia y, en menor medida, su presencia previa a que éstas siquiera estallaran. Un ejemplo de ello se pudo observar en el "Desfile de los 200 años", cuyo comienzo marcó un inesperado quiebre con los relatos oficiales hasta ese momento delineados en la medida en que el primer cuadro fue destinado a exhibir la diversidad de pueblos originarios preexistentes en el territorio que luego se conocería como Argentina. ${ }^{119}$

Es que, a diferencia de lo sucedido en Bolivia y Ecuador, este sujeto había permanecido en los márgenes de la narrativa oficial bicentenaria, con la excepción de una única referencia que tuvo lugar durante la inauguración de la "Galería de los Patriotas Latinoamericanos", cuando Fernández de Kirchner afirmó: "el camino para nosotros es el mismo que tomaron San Martín, Bolívar, O’Higgins, Artigas, José Martí, que antes lo habían llevado a cabo los pueblos originarios con mucha valentía”. ${ }^{120}$

Respecto al accionar popular durante el proceso de independencia, éste fue representado, durante el desfile, en aparente sintonía con el revisionismo histórico a

\footnotetext{
118 Véanse los discursos pronunciados por Cristina Fernández de Kirchner en Salta el 25 de mayo 2008 o en Tucumán el 9 de julio de 2015. Asimismo, es preciso recordar que fue el Frente para la Victoria (FpV) quien presentó en el 2016 en el Congreso de la Nación un proyecto de ley que establecía al 17 de junio como feriado nacional y día no laborable en todo el territorio nacional "en conmemoración al paso a la inmortalidad del general don Martín Miguel de Güemes".
}

119 Respecto a la reivindicación del pasado indígena "como herencia común de todos los americanos", Tulio Halperín Donghi recuerda que "en 1812, en los festejos en que la parroquia de San Nicolás en Buenos Aires, celebra el fracaso de la conspiración contrarrevolucionaria capitaneada por Álzaga, los cuatro niños que 'cantaban de tiempos en tiempos varias canciones llanas y por puntos de solfa' estaban vestidos indios, y en ese mismo año los primeros morteros fundidos en Buenos Aires son bautizados el Túpac Amaru y el Mangoré” (2005 [1972]: 174).

120 La Nación, 26 de mayo de 2010. Disponible en: https://www.lanacion.com.ar/1268730-construyamosun-pais-para-todos

Respecto al desfile, queda el interrogante de cuánto de esta decisión, la cual resultó un cambio de último minuto que buscó constituirse en una reparación en el campo de lo simbólico, no respondió también al hecho de que esa misma semana representantes de diversas comunidades indígenas se trasladaron a la capital para manifestarse frente a la Casa de Gobierno y reclamar respeto hacia la diversidad cultural y sus derechos a la tierra. 
través dos carrozas dirigidas a resaltar una épica de gloria, pueblo y sacrificio, además del espíritu de comunión y solidaridad colectiva que habría rodeado a aquel acontecimiento fundante de la nación. ${ }^{121}$ La primera de ellas imitó la marcha de los pobladores de San Salvador de Jujuy y las tropas del Ejército del Norte lideradas por Belgrano, quienes -avanzando por la avenida 9 de Julio entre antorchas y música de tambores- simbolizaron al "Éxodo Jujeño".

Posteriormente, se reprodujo el "Cruce de los Andes", esto es, la marcha de las tropas comandadas por San Martín, entre las cuales despuntaba el batallón de negros en medio de nieve artificial, mulas y caballos. Lo notable de esta última es que su avance se produjo nada más ni nada menos que al son de la militar Marcha de San Lorenzo, la cual -surgida en 1901 en el seno del llamado "orden conservador" y convertida en uno de sus emblemas más distintivos- a la par que rendía homenaje al heroico granadero de origen zambo, Juan Bautista Cabral, era dedicada al ministro de Guerra de Julio A. Roca, Pablo Riccheri, oriundo justamente de aquella localidad.

Por otro lado, es preciso señalar que, a diferencia del énfasis realizado por los gobiernos del MAS y la RC en el rol de las mujeres durante la independencia, dicho sujeto permaneció en gran medida ausente de las lecturas oficiales efectuadas por el Poder Ejecutivo argentino sobre el período en cuestión, salvo por la fugaz declamación de que la Revolución de Mayo había sido "de hombres y mujeres" o la incorporación de los retratos de la patriota porteña María Sánchez de Thompson y la heroína chuquisaqueña Juana Azurduy de Padilla en el Salón Mujeres Argentinas del Bicentenario, creado en el 2009, al interior de la Casa Rosada. ${ }^{122}$

121 En el $204^{\circ}$ aniversario de la Revolución, la presidenta precisaría: "quiero aclarar algo, quiero hacer hincapié en estas palabras, 'Revolución' y de 'Mayo' porque muchas veces y hasta a mí también me ha pasado, que cuando recordamos el 25 de Mayo, solo lo hacemos recordando a un puñado de hombres patriotas, próceres que pasaron a la historia, pero nos olvidamos del pueblo. Porque cualquier esfuerzo individual, cualquier esfuerzo de un puñado de hombres, no pueden construir una nación. Solamente lo hace cuando ese puñado de hombres es acompañado por el pueblo.Por eso, siempre debemos recordar que puede haber pueblo y no revolución. Lo que nunca puede haber es revolución sin pueblo. Esto lo tenemos que tener todos muy claro". Discurso pronunciado por Cristina Fernández de Kirchner en Buenos Aires, 25 de mayo de 2014. Disponible en: https:/www.casarosada.gob.ar/informacion/archivo/27534-actoconmemorativo-del-204d-aniversario-de-la-revolucion-de-mayo-palabras-de-la-presidenta-de-la-nacion

122 Cabe mencionar que la exaltación de Azurduy, quien también en el 2009 había sido ascendida al grado máximo de Generala del Ejército argentino, se profundizaría hacia el final del mandato presidencial de Fernández de Kirchner cuando en junio de 2014 el Poder Ejecutivo decidió la creación de un nuevo billete de 10 pesos en conmemoración de Manuel Belgrano y Juana Azurduy y cuando en julio de 2015 se reemplazó la estatua de Cristóbal Colón ubicada detrás de la Casa Rosada por una de la heroína en un intento simbólico por cuestionar la historia de raigambre colonial y patriarcal. 
Así, los modos en que el gobierno de Fernández de Kirchner restauró el proceso de independencia dieron cuenta de un intento por reivindicar la gesta patriótica como criolla y popular, ideada y conducida por grandes hombres pero apoyada en las masas anónimas, lo cual no significó el abandono de aquella historiografía de corte liberal retóricamente cuestionada por la entonces mandataria ni una apelación total al arsenal del revisionismo histórico, sino más bien un cruce o conjugación de ellas. Con todo y pese a los empeños por restituir la presencia de "lo subalterno", el panteón de los héroes de la independencia continuó asido a las -más o menos- tradicionales figuras masculinas letradas y militares.

En Venezuela, con motivo de la celebración del bicentenario de la Revolución del 19 de abril, se emitió por cadena nacional de radio y televisión un programa especial, en donde el entonces presidente y parte de su equipo de gobierno recorrieron una serie de sitios históricos de Caracas como excusa para recordar, en vísperas del aniversario, la historia del proceso independentista. En la Casa Natal de Simón Bolívar, Chávez, dialogando con dos niños disfrazados de Simón Bolívar y del cacique Guaicaipuro, explicaba que el Libertador había sido

un hombre del pueblo, un niño del pueblo, después un joven estudioso muy inquieto y después se hizo soldado, fue un soldado, fue general en jefe y un gran comandante y un gran ciudadano y hoy, Bolívar hoy es el pueblo, es la Patria. Cuando llegó Colón empezó el desastre, empezaron a matar a los indios, empezaron a dañarlos, fue la colonia a esclavizarlos y pasaron 300 años después fue que ocurrió la liberación con Bolívar, fijate y tenemos 200 más, van 500 años de lucha por la liberación de nosotros. 123

De modo que Bolívar -ya no mantuano y defensor del orden sino anti-esclavista, llanero y símbolo de la revolución social, fuertemente influenciado por sus maestros, Simón Rodríguez y Andrés Bello-124 fue el encargado de continuar y consumar la lucha

\footnotetext{
123 Discurso pronunciado por Hugo Chávez Frías en Caracas, 18 de abril de 2010. Disponible en: http:// www.todochavez.gob.ve/todochavez/637-intervencion-del-comandante-presidente-hugo-chavez-duranteprograma-especial-con-motivo-de-la-celebracion-del-bicentenario-del-inicio-de-la-gesta-independentistade-venezuela-el-19-de-abril-de-1810

124 En efecto, Chávez afirmaba durante esa misma emisión que Bolívar "era [de] una familia de mucho dinero y tenían haciendas y esclavos, pero él cuando estaba como tú [en referencia al niño], no le gustó aquello y entonces después él liberó los esclavos" y "se hizo llanero". Ibídem.
} 
anti-colonial que, trescientos años atrás, había sido inaugurada por los sectores populares:

cuando el camino llegó al 19 de abril aquí a Caracas era un camino ya de 300 años de batalla, nadie vaya a pensar que eso fue un hecho que cayó como del cielo y ocurrió espontáneamente, no, no, eran 300 años de lucha, el 19 de abril recoge los mártires indígenas y hay que recordar bueno todo, las grandes insurrecciones, la de José Leonardo Chirinos (sic) 1795 allá en Coro una gran rebelión negra e indígena y otras muchas rebeliones, el negro Miguel un poquito antes, verdad, Andresote en Yaracuy, los negros alzados en Barlovento, los indios hicieron mil rebeliones. ${ }^{125}$

Nuevamente, como en Ecuador y Bolivia, los alzamientos de los sectores populares -en este caso particular, de indígenas pero, sobre todo, de negros y castasreaparecían en escena -ya sea en el relato de Chávez o en el videomapping proyectado en el Paseo Los Próceres-126 como los primeros intentos libertarios que sentaron las condiciones de posibilidad para el "19 de abril". Así, se enlazaba dicha jornada no solo a los enfrentamientos protagonizados, hacia 1560, por el cacique Guaicaipuro en contra de los ejércitos españoles, sino también a cuatro "grandes insurrecciones" negras: la de los esclavos de las minas de Buría en 1552 cuyo jefe había sido el negro Miguel, la de los negros libres y esclavos de los valles del Río Yaracuy iniciadas entre 1730 y 1733 bajo el mando de Andrés López del Rosario, la de los negros de Coro en 1795 conducidas por José Leonardo Chirinos y José Caridad González y, finalmente, la de los esclavos y negros libres de la región de Barlovento en 1812 promovida por hacendados y sacerdotes fidelistas en contra de las órdenes dictadas por el entonces recientemente proclamado "Generalísimo de Venezuela", Francisco de Miranda. 127

Sin importar la naturaleza disímil de cada una de esas actuaciones, el Poder Ejecutivo venezolano las entendía como una suerte de adelanto del heroísmo y valentía

\footnotetext{
125 Discurso pronunciado por Hugo Chávez Frías en Caracas, 18 de abril 2010. Disponible en: http:// www.todochavez.gob.ve/todochavez/637-intervencion-del-comandante-presidente-hugo-chavez-duranteprograma-especial-con-motivo-de-la-celebracion-del-bicentenario-del-inicio-de-la-gesta-independentistade-venezuela-el-19-de-abril-de-1810

126 Videomapping disponible en: http://albaciudad.org/2011/08/videos-y-fotos-asi-fue-el-desfilebicentenario-independencia-para-siempre/

127 Sobre estas rebeliones, véase Brito Figueroa (1988); Rojas (1993); Gómez (2008); Guédez (2011); Paredes Muñante (2015).
} 
que se observaría entre las figuras criollas encargadas de "continuar" la lucha por la independencia. En efecto, al reanudar el relato, Chávez señalaba:

Luego tenemos (...) la rebelión de Gual y España, la conspiración de Gual y España fue un gran contenido ideológico revolucionario, ya con una consigna, con una bandera, con un proyecto. Miranda que llegó ahí a las costas casi desembarca en Ocumare no pudo, después la Vela de Coro 1806. Luego la rebelión o la conspiración de los Mantuanos 1808 y luego los conflictos entre Francia y España, el imperio español golpeado por Napoleón y luego aquí se fermenta todo aquello de 300 años de lucha y un día como hoy 200 años hace a esta hora, es posible que estuviera lloviendo estaba entrando el invierno, se reunían aquí desde comienzos del año 1810 se incrementaron las reuniones, las conspiraciones, los Bolívar. ${ }^{128}$

La conspiración de 1797 en La Guaira -protagonizada por los militares criollos Manuel Gual y José María España, quienes, influenciados por el liberalismo francés, se propusieron, entre otros objetivos, instaurar un sistema republicano-, los intentos de desembarco en Ocumare y La Vela de Coro encabezados por Miranda en 1806 -sucesos que, además, fueron elegidos para ser representados en el desfile del bicentenario del 5 de julio de 2011-129 y la conjura de los mantuanos en 1808 -primer empeño por constituir una junta de gobierno en Caracas tras las abdicaciones de Bayonaconstituyeron, así, los otros pilares de un largo proceso de insurrección que, finalmente, habría terminado de estallar el 19 de abril de 1810, cuando -en palabras del mandatario- tuvo lugar una rebelión "cívico-militar", "con incrustaciones burguesas" pero "cuya alma era el pueblo"; 130 un levantamiento que contó con la participación de

los Bolívar, los Toro, los Coto Paúl, los Ribas y claro y esos son los nombres que recogió la historiografía porque eran las familias, vamos a llamar notables pero

\footnotetext{
128 Discurso pronunciado por Hugo Chávez Frías en Caracas, 18 de abril de 2010. Disponible en: http:// www.todochavez.gob.ve/todochavez/637-intervencion-del-comandante-presidente-hugo-chavez-duranteprograma-especial-con-motivo-de-la-celebracion-del-bicentenario-del-inicio-de-la-gesta-independentistade-venezuela-el-19-de-abril-de-1810

${ }^{129}$ Véase: http://albaciudad.org/2011/08/videos-y-fotos-asi-fue-el-desfile-bicentenario-independenciapara-siempre/

130 Discurso pronunciado por Hugo Chávez Frías en Caracas, 18 de abril de 2010. Disponible en: http:// www.todochavez.gob.ve/todochavez/637-intervencion-del-comandante-presidente-hugo-chavez-duranteprograma-especial-con-motivo-de-la-celebracion-del-bicentenario-del-inicio-de-la-gesta-independentistade-venezuela-el-19-de-abril-de-1810
} 
fijense ustedes para hacer justicia al pueblo, al pueblo llano, a los soldados llanos ¿eh? a los solados (sic) llanos porque fue una unión que se dio allí entre la clase alta o sectores de la clase alta y las clases bajas ¿eh? los pardos, los negros, los militares, los civiles. ${ }^{131}$

Así, el panteón de los héroes de la independencia trazado por Chávez continuó exaltando los tradicionales próceres de origen "notable” como Manuel Gual, José María España, Francisco de Miranda, Simón Bolívar, José Félix Ribas, Francisco Antonio “Coto” Paúl, así como Fernando y Francisco Rodríguez del Toro, los cuales habían sido objeto de reivindicación por parte de la historiografía nacional venezolana del siglo XIX.

Sin embargo, el entonces mandatario proponía dos reformulaciones en clave "revisionista": en primer lugar, esa revolución separatista conducida por los líderes criollos no podía ser explicada sin destacar su ligazón con las actuaciones previas del cacique Guaicaipuro, el negro Miguel, Andrés López del Rosario y José Leonardo Chirinos; y, en segundo lugar, no podría haber triunfado sin la movilización y participación del "pueblo llano".

Por otro lado, cabe reparar en el modo en que Chávez caracterizó a la figura de José Antonio Páez, responsable de impulsar la autonomía de Venezuela respecto del gobierno central de Bogotá y, en ese sentido, de "traicionar" el proyecto bolivariano de la Gran Colombia.132 Aquél -que "nunca se subordinó en verdad a Bolívar (...) [que] se creía el más grande (...) y al final terminó imponiéndose por la fuerza, no por la

\footnotetext{
${ }^{131}$ Ibídem.
}

132 Según el mandatario, era necesario distinguir dos momentos del prócer en cuestión: "Páez era el caudillo de los llanos (...) lo que ocurrió después es otra historia, pero al Páez de Las Queseras hay que rendirle tributo. Al 'Taita', que supo recoger de las sabanas a los peones a los zambos, a los negros, como Pedro Camejo, a los hombres mejores que con él andaban, él supo interpretarlos y unificarlos, en aquél ejército que hizo expresar a Pablo Morillo ante el rey de España, años después, aquella frase: 'Su Majestad, es que aquellos no son ningunos salvajes'". Discurso pronunciado por Hugo Chávez en Caracas el 01/04/2004. Disponible en: http://www.todochavez.gob.ve/todochavez/959-intervencion-delcomandante-presidente-hugo-chavez-en-acto-de-instalacion-del-primer-taller-de-alto-nivel-misionvuelvan-caras

Pese a esos matices, Chávez llegó a afirmar que "podrá crujir este Panteón, que cruja si quiere (...) José Antonio Páez, que cruja en su tumba que aquí está... no debería estar aquí desde mi punto de vista (...) en este Panteón hay de todo, hay patriotas y hay traidores (...) José Antonio Páez el más grande de los traidores, el más grande de los corruptos de la historia venezolana". Discurso pronunciado por Hugo Chávez Frías en Caracas, 17 de diciembre de 2006. Disponible en: https://www.youtube.com/watch? $\underline{\mathrm{v}=3 \mathrm{uEWoXELoP0}}$ 
razón"133 y que "se entregó a la oligarquía, (...) terminó siendo terrateniente (...) dueños de esclavos, terminó siendo un antibolívar porque Bolívar, como sabemos, nació rico de cuna y entregó todo"-134 era, de esta manera, excluido del panteón oficial delineado por el entonces mandatario.

En esta reinterpretación de la gesta independentista, la actuación de las mujeres también buscó, aunque someramente, ser reconsiderada. "La historia que es muy machista, recoge casi siempre los nombres masculinos", 135 explicaba Chávez al reivindicar por cadena nacional a María Concepción Palacio por haber sido la madre de Bolívar, a la negra Hipólita en su rol de nodriza del Libertador -cuyo apodo había sido elegido en el 2006 para denominar una de las misiones sociales lanzadas por el gobierno y su imagen, una de las pocas en ser incorporadas al videomapping del bicentenario- $y$ a María Teresa Rodríguez del Toro, la esposa de Bolívar que encarnaba, según Chávez, el "vínculo con la España buena, porque ella era española". ${ }^{136}$

Junto a ellas, el entonces mandatario recordaba también a Josefa Camejo encargada de subscribir, junto a otras damas patricias, el documento político conocido como "Representación que hace el Bello Sexo al Gobierno de Barinas" exhortando que se incorporara a las mujeres a la lucha por la independencia, cuyos restos simbólicos habían sido incorporados el 8 de marzo de 2002 al Panteón Nacional-, a Manuela Sáenz -la "Libertadora del Libertador" que pese a no haber nacido "en Caracas (...) es de toda la América"-137 y a Luisa Cáceres de Arismendi -primera mujer en ser ingresada al Panteón Nacional en 1876 bajo el guzmancismo y cuya imagen, además de haber sido la

133 Discurso pronunciado por Hugo Chávez Frías en Caracas, 18 de abril de 2010. Disponible en: http:// www.todochavez.gob.ve/todochavez/637-intervencion-del-comandante-presidente-hugo-chavez-duranteprograma-especial-con-motivo-de-la-celebracion-del-bicentenario-del-inicio-de-la-gesta-independentistade-venezuela-el-19-de-abril-de-1810

134 Discurso pronunciado por Hugo Chávez Frías en Caracas, 25 de enero de 2012. Disponible en: http:// www.todochavez.gob.ve/todochavez/50-intervencion-del-comandante-presidente-hugo-chavez-en-actode-graduacion-de-oficiales-de-tropa-de-la-fuerza-armada-nacional-bolivariana-promocion-coronelfrancisco-farfan

135 Discurso pronunciado por Hugo Chávez Frías en Caracas, 18 de abril de 2010. Disponible en: http:// www.todochavez.gob.ve/todochavez/637-intervencion-del-comandante-presidente-hugo-chavez-duranteprograma-especial-con-motivo-de-la-celebracion-del-bicentenario-del-inicio-de-la-gesta-independentistade-venezuela-el-19-de-abril-de-1810

136 Ibídem.

137 Ibídem. 
elegida para el billete de veinte bolívares en el 2007, también se destacó en el videomapping-.

En consecuencia, la lectura sobre el pasado independentista propuesta por el Poder Ejecutivo venezolano intentó matizar los enfoques historiográficos clásicos o tradicionales - de corte nacionalista y liberal- que reducían los orígenes de la gesta emancipadora a las acciones desarrolladas por las élites urbanas letradas en Caracas a partir de 1810 (Morales Peña, 2009; Cardozo Galué, 2010). Ahora bien y en línea con lo sucedido en Ecuador y Argentina, esto en ningún momento supuso una ruptura clara o total con aquellas estructuras interpretativas.

Por un lado, la reconstrucción oficial del período en cuestión permaneció sujeta a los sucesos protagonizados por los "mantuanos" en Caracas entre 1808 y 1812, obviándose cualquier referencia a los conflictos y/o ambigüedades al interior del movimiento revolucionario, así como a los levantamientos criollos y populares antiseparatistas surgidos en otras provincias de la Capitanía que rechazaron la autoridad de dicha ciudad.

Lo que se cuestionó, en todo caso, fue el rechazo por parte de estos enfoques a reconocer los aportes de los indios, negros, castas y llaneros a la cultura y la historia nacional, así como el lugar de las mujeres en ella. De ahí que el proceso independentista haya sido presentado como una rebelión "cívico-militar" de "hombres y mujeres", asentada en la unión entre el pueblo anónimo y las élites caraqueñas, cuyo origen se remonta a la larga serie de insurrecciones populares iniciadas en el siglo XVI.

Por el otro y a contramano de las primeras versiones "revisionistas" sobre la independencia (Quintero, 2007), el mito bolivariano sobre el cual se edificó la historia nacional venezolana, continuó siendo -aunque despojado de sus aristas conservadorasel eje sobre el cual se reconstruyó y cimentó la memoria histórica de la nación, mostrándose a Simón Bolívar como el sosías arcaico de Chávez o a este último como el "Libertador" del siglo XXI.

Quizás con la única excepción del relato elaborado por Morales en El Villar, la restauración de los panteones nacionales y los mitos de origen efectuada por los Poderes 
Ejecutivos de Bolivia, Ecuador, Argentina y Venezuela en ocasión de las celebraciones bicentenarias permite advertir, mutatis mutandis, una tentativa por conciliar las historias liberales de las grandes figuras que, a través de los mitos fundacionales, situaron al Estado-nación como sujeto de la historia y posicionaron a las élites criollas anticoloniales y sin fisuras- en el centro de esa escena, y cierta tendencia "revisionista" de izquierda que, crítica con esas lecturas, exaltó a los sectores subalternos como auténticos sujetos revolucionarios antes y durante las “inconclusas" gestas emancipadoras.

Esta conjugación, dirigida a reponer y valorizar la visión de los "vencidos" de un modo que fuera compatible con las narrativas históricas tradicionales $-\mathrm{y}$, sobre todo, populares-, no intentó, lógicamente, desmontar o problematizar los mitos de orígenes, sino reformularlos de modo que pudieran dar cuenta de construcciones identitarias más amplias e inclusivas de la diferencia capaces de eliminar las asperezas de la historia y nutrir la sensación de continuidad con aquel pasado remoto y originario.

De igual forma, la mirada lineal, homogénea y esencialista inherente a las historias patrias fue decisiva al momento de reforzar y legitimar cada uno de estos proyectos políticos, los cuales buscaron ser exhibidos como herederos y continuadores de las -"gloriosas" aunque "inacabadas"- gestas independentistas.

II. De la "primera" a la "segunda" independencia. Las otras gestas precursoras

Si para estas experiencias de gobierno sus raíces o fundamentos se hallaban en los levantamientos indígenas ocurridos durante la colonia y/o en las revoluciones de independencia que pusieron fin al dominio español, otros episodios desarrollados a lo largo de los siglos XIX y XX serían, asimismo, encumbrados y enlazados a éstos, dando por resultado una genealogía de acontecimientos y/o personalidades notables, 
superadores uno de los otros, que finalmente habrían encontrado su consumación en aquel particular presente sudamericano.

En Bolivia, las referencias históricas sobre las cuales se apoyó el gobierno del MAS involucraron, desde sus inicios en el poder,138 al líder chiriguano (o guaraní) Apiaguaiki Tumpa -que encabezó las rebeliones contra el gobierno conservador y los hacendados blancos en el Chaco boliviano en 1892, razón por la cual fue declarado en julio de 2009 "héroe nacional y mártir de la lucha por la liberación, soberanía y dignidad del Pueblo Guaraní”-,139 así como al líder aymara Zárate Willka -quien se unió a la causa liberal durante la Guerra Federal de 1898-99 a cambio de la restitución de las tierras comunales- ${ }^{140}$

Junto a estas figuras aparecía, asimismo, el abogado cruceño y líder del Partido Igualitario, Andrés Ibáñez, el cual protagonizó el alzamiento federal llamado Revolución de la Igualdad de 1876-77 en Santa Cruz. De hecho, fue su nombre el elegido para denominar la Ley Marco de Autonomías y Descentralización promulgada en julio de 2010, ya que

De todas las acciones, rebeldías y procesos, destaca la revolución igualitaria de 1877 liderada por Andrés Ibáñez, quien al grito de "Todos somos iguales" lanzado en plena plaza de armas frente a los representantes más acérrimos del orden patriarcal feudal en Santa Cruz, se convirtió en el cuestionamiento a la base misma

\footnotetext{
138 Véase el discurso de posesión presidencial del 22 de enero de 2006 donde Morales ya esbozaba un primer panteón de héroes nacionales al discurrir sobre la importancia de "recordar a nuestros antepasados (...) Manco Inca, Túpac Katari, Túpac Amaru, Bartolina Sisa, Zárate Villca, Atihuaiqui Tumpa, Andrés Ibáñez, Che Guevara, Marcelo Quiroga Santa Cruz, Luis Espinal (...)”. Disponible en: https:// www.pagina12.com.ar/diario/especiales/18-62330-2006-01-30.html
}

${ }^{139}$ Ley N ${ }^{\circ} 4051$ publicada el 7 de julio de 2009. Disponible en: https://www.lexivox.org/norms/BOL-4051.xhtml

Por otro lado, cabe agregar que la imagen del líder guaraní fue incorporada en el 2018 al nuevo billete de diez bolivianos.

140 Respecto a la reivindicación de Willka, ésta siempre vino acompañada de una condena al jefe del Partido Liberal elegido presidente en 1899, José Manuel Pando, por haber reprimido - una vez conseguido el triunfo sobre el bando conservador-al movimiento indígena y haberlo responsabilizado de las matanzas de Mohoza, Ayo Ayo y Corocoro (Irurozqui, 1992; 2011).

De hecho, el 22 de abril de 2018 -aniversario del encarcelamiento de Willka- el mandatario publicó en su cuenta de Twitter: "Como hoy, 1899, el gobierno de Manuel Pando, que en la Guerra Federal había requerido de los indígenas para vencer a los unionistas, capturó a sus líderes Pablo Zárate Willka, Lorenzo Ramírez y Juan Lero, para procesarlos. Cuatro años después, Zárate Willka sería asesinado". Disponible en: https://twitter.com/evoespueblo/status/988011452933033986?lang=en Meses después, con la puesta en circulación del nueve billete de cincuenta bolivianos con la imagen de Willka, el rechazo por parte de Sucre a dicha decisión (especialmente, por los sucesos en la iglesia de Ayo Ayo) reavivó la polémica en torno a la exaltación que el Poder Ejecutivo hacía del líder aymara. 
del orden estamental que imperaba en todo el país. El movimiento de Ibáñez se fundó en el convencimiento pleno de la necesidad de instaurar una estructura económica y política que permita superar la desigualdad y la injusticia. 141

Efectuando un salto en el tiempo, el gobierno del MAS ubicaba un nuevo jalón histórico en el "socialismo militar" boliviano de los años treinta y cuarenta, experiencia particularmente valiosa al momento de cimentar la alianza entre las Fuerzas Armadas y el movimiento indígena-campesino que se había propuesto construir una vez en el poder (Stefanoni, 2006). ${ }^{142}$ Así, Morales explicaba que

Desde la Guerra del Chaco nace un sentimiento del nacionalismo militar boliviano, a la cabeza del Teniente Coronel Germán Busch, implementando por primera vez políticas sociales, atendiendo la demanda de los sectores abandonados, como siempre termina asesinado. No podemos olvidar al Cnl. David Toro que por primera vez y gracias a la Guerra del Chaco, gracias al nacionalismo de las Fuerzas Armadas, el año 1938 nacionaliza el petróleo boliviano (...)

Gualberto Villarroel por primera vez en la historia acabó con el pongueaje y reconoció las tierras comunitarias, esos son los militares patriotas que aportaron en la transformación.

El delito de Gualberto Villarroel fue la extinción del pongueaje, reconocer las tierras comunitarias y por eso acabó colgado por las oligarquías mineras, por los latifundistas. Ahora, hermanas y hermanos, en este nuevo milenio, nunca más

\footnotetext{
${ }^{141}$ Ley N ${ }^{\circ} 031$ publicada el 19 de julio de 2010. Disponible en: http://www.planificacion.gob.bo/uploads/ marco-legal/Ley\%20N\%20031\%20DE\%20AUTONOMIAS\%20Y\%20DESCENTRALIZACION.pdf Ahora bien, la reivindicación que hizo Morales de Ibáñez se vio acompañada de algunas oscilaciones a lo largo del tiempo. Un ejemplo de ello se pudo observar el 25 de diciembre de 2017 cuando el presidente construyó un paralelismo entre la actuación de Ibáñez y la de uno de los mayores representantes de la causa autonomista cruceña: "Como hoy, 1876, Andrés Ibáñez declaró la federalización de facto de Santa Cruz, después de ejecutar a la autoridad legalmente constituida. 1983, Carlos Valverde Barbery planteó federalismo y la 'destrucción de la república', con el justificativo que era unitaria y centralizada". Disponible en: https://twitter.com/evoespueblo/status/945274891137421312
}

142 Sobre este vínculo, las palabras de Morales durante los actos del bicentenario en La Paz resultan esclarecedoras: "Depende de que las clases políticas den utilidad a las Fuerzas Armadas y cuando damos buena utilidad a las Fuerzas Armadas son queridas por su pueblo. En las dictaduras cuando un niño veía a un militar uniformado se escapaban y ahora ese niño dice: el tío está viniendo con plata. Ustedes saben, sobre todos hermanos del campo". Discurso pronunciado por Evo Morales en La Paz el 16/07/2009. Disponible en: http://www.cubadebate.cu/especiales/2009/07/16/declaraciones-del-presidente-de-boliviaevo-morales-en-los-actos-por-la-celebracion-del-bicentenario-del-grito-libertario-video/ \#.V2BGx5HhCM8 
habrá descuartizamientos, tampoco habrá colgamientos. Es una lucha histórica de reivindicaciones y de acabar con esta clase de políticas de escarmiento. ${ }^{143}$

De este modo, el altar de la patria se ampliaba al incorporar a Germán Busch, David Toro y Gualberto Villarroel, tres militares que, según el mandatario, fueron los primeros en "aportar" desde el Estado a "la transformación" de Bolivia por haber desplegado una retórica y una práctica reformistas de tintes nacionalistas, antiliberales y antioligárquicas.

En esta línea, el Poder Ejecutivo volvía a identificar otro momento decisivo para la historia boliviana en la Revolución Nacional de 1952. Aunque presentada como un "levantamiento" de carácter insuficiente en contraposición al gobierno de la Revolución Democrática y Cultural que sabía "cómo gobernar sometidos al pueblo",144 Morales se vio obligado a reconocer que

hasta el año 1952 no había el voto universal. Conocen muy bien, el voto universal también ha costado sangre. Antes del 52 decían que los campesinos son analfabetos y no pueden votar. Los campesinos no pagan impuestos y como no lo hacen no pueden ir a elegir autoridades. Peor con las mujeres que no tenían derecho a elegir ni siquiera a las autoridades. Gracias al levantamiento de 1952 conseguimos el voto universal pero solo servía para elegir autoridades y hemos tenido que esperar otros 50 años para incorporar el referéndum. Hemos conseguido en 2004 incorporar en la reforma de la Constitución el referéndum y ahora podemos decidir el futuro del país. Desde la Presidencia sabemos cómo gobernar sometidos al pueblo (...). ${ }^{145}$

\footnotetext{
143 Discurso pronunciado por Evo Morales en La Paz, 7 de febrero de 2009. Disponible en: http:// www.apoyobolivia.net/discurso-evo-morales

144 El carácter medido de esa reivindicación responde a la mirada crítica del MAS respecto a esta experiencia política, siendo algunos de sus principales reproches el hecho de no haber sido conducida por el movimiento indígena, la "campaña de homogeneización" del campesinado que habría intentado erosionar las identidades indígenas, la complicidad de algunos de sus miembros hacia el régimen dictatorial de Hugo Banzer, así como el giro neoliberal que experimentó el liderazgo del Movimiento Nacionalista Revolucionario décadas después. En efecto, Morales publicaba en su cuenta de twitter, en las vísperas del $46^{\circ}$ aniversario del golpe de Estado encabezado por Banzer, una foto en donde se veía a este último junto a Víctor Paz Estenssoro y Mario Gutiérrez (líder de Falange Socialista Boliviana) con un pie de foto que rezaba: "Dictador Banzer, con el MNR y FSB de cómplices, abrieron la era de gobiernos de facto dirigidos por la CIA y organizados en el Plan Cóndor". A continuación, agregaba: "ADN [Acción Democrática Nacionalista] recicló en el poder a Banzer. Gobernó con el MNR, MIR, NFR y otros partidos de derecha en la época del neoliberalismo". Disponible en: https://twitter.com/evoespueblo/ status/898926137052729345
}

145 Discurso pronunciado por Evo Morales en La Paz, 16 de julio de 2009. Disponible en: http:// www.cubadebate.cu/especiales/2009/07/16/declaraciones-del-presidente-de-bolivia-evo-morales-en-losactos-por-la-celebracion-del-bicentenario-del-grito-libertario-video/\#.V2BGx5HhCM8 
Esta articulación de episodios y figuras históricas que el Poder Ejecutivo boliviano había ido cosechando y exhibiendo como antecedentes a la RDC se ampliaba, por un lado, con la exaltación de Juan José Torres, con cuyo nombre fue bautizada "la primera Escuela Antiimperialista de las Fuerzas Armadas en Latinoamérica".146 Para Morales, el militar y político boliviano -asesinado en Buenos Aires en el marco del llamado Plan Cóndor- también merecía ocupar un lugar destacado dentro de la memoria histórica de la nación ya que

El "pecado" del general Juan José Torres, fue la nacionalización de la mina Matilde, y haber cerrado Guantanamito. Tampoco le perdonaron haber expulsado al Cuerpo de Paz, que tenía denuncias por esterilizar a las mujeres en las minas para evitar que nazcan nuevos comunistas. 147

Por otro lado, el mandatario completaba su panteón al reivindicar al escritor y político socialista, Marcelo Quiroga Santa Cruz y al cineasta, periodista y sacerdote jesuita, Luis Espinal -ambos asesinados en 1980 bajo la dictadura de Luis García Meza Tejada y Luis Arce Gómez-:

No podemos olvidar la lucha democrática de Marcelo Quiroga Santa Cruz, de nuevas generaciones que apuestan por su pueblo, transformaciones en democracia y defendiendo la democracia; pero, sobre todo, no podemos olvidar a un padre, Luis Espinal, que dio su vida por la vida de los demás, fue de la Iglesia Católica. 148

Es así que el Poder Ejecutivo boliviano, al desplazarse por los siglos XIX y XX, fue recogiendo aquellos sucesos, símbolos y personajes que -aunque truncados y/o insuficientes- le permitieron construir una tradición ideológica que pudiera servir de precedente, sostén e inspiración a la RDC, revolución que no solo se había propuesto

\footnotetext{
$146 \mathrm{Al}$ respecto, véase: https://www.consuladodebolivia.com.ar/2016/08/17/la-primera-escuelaantiimperialista-las-ff-aa-latinoamerica-juan-jose-torres-bolivia/

147 Palabras publicadas en la cuenta de twitter oficial de Evo Morales el 21/08/2018. Disponible en: https://twitter.com/evoespueblo/status/1032097837457305600?lang=en
}

148 Discurso pronunciado por Evo Morales en La Paz, 7 de febrero de 2009. Disponible en: http:// www.apoyobolivia.net/discurso-evo-morales 
encarnar y conjugar los rasgos más sobresalientes de cada uno de ellos, sino, especialmente, perfeccionarlos y llevarlos a cabo en pos de la defensa de la "integridad de la patria". ${ }^{149}$

Por su parte y al momento de hacerse de una genealogía, el Poder Ejecutivo ecuatoriano encontró en la "revolución alfarista" la heredera indiscutible de la gesta de independencia. La figura del "Viejo Luchador",150 líder del embate contra el conservadurismo de principios de siglo XX y "continuador" de la "primera" independencia, adquiriría, entonces, un lugar central en la retórica oficial, sirviendo de fundamento a la identidad política e ideológica del correísmo:

\begin{abstract}
Aunque invocó las mismas ideas liberales que animaron a los caudillos de la Independencia, la revolución que promovió y llevó a la victoria fue sobrepasándolas en su realización histórica. Por eso, la obra visionaria de Alfaro no pudo menos que chocar con los intereses del capital bajo su forma conservadora y santurrona, pero también bajo su forma liberal-mercantilista, cuyos defensores se encontraban fuertemente vinculados a los intereses de la propiedad terrateniente, el comercio y sobre todo la banca (...)

De Alfaro, reivindicamos la consigna de un país liberado de las ataduras eclesiásticas, de la ignorancia y el oscurantismo; formado por hombres y mujeres dotados de una conciencia enriquecida por los beneficios del saber e incorporados a una América solidaria (... $)^{151}$
\end{abstract}

\footnotetext{
${ }^{149} \mathrm{Al}$ referirse a la necesidad de defender la patria de los enemigos de la nación, García Linera explicaba durante el aniversario de la Declaración de la Independencia en el 2009: "Hemos tenido enemigos de la patria internos y externos y lo seguiremos teniendo. Los tuvimos en 1825, en 1900, en 1960 y en 2008. Quiero que sepan que los hemos derrotado y los vamos a derrotar las veces que sea necesario. Una y otra vez porque la patria no se toca, no se divide, no se la mutila, no mientras estemos vivos nosotros. (...) al egoísmo externo que roba la riqueza de la nación; a la ambición privada que quiere convertir el bien común en riqueza privada; al que privatiza los recursos del Estado y destruye las empresas públicas; y principalmente al que por defender su hacienda, su empresa, su poder local o regional, es capaz de renunciar a la integridad de la patria (...) Si vuelven a levantar la cabeza, los volveremos a aplastar una y otra vez." Fragmento de discurso pronunciado por Álvaro García Linera en Sucre, 6 de agosto de 2009. Disponible en: http://www.jornadanet.com/Hemeroteca/n.php?a=35535-1\&f=20090807
}

150 Conocido como el "Viejo Luchador", Eloy Alfaro Delgado fue presidente de la República de Ecuador (1897-1901 y 1906-1911), general de División del Ejército desde 1895 y líder de la Revolución liberal (1895-1924). Se le atribuye la defensa de la democracia, la unidad nacional, la integración territorial, el laicismo, la legalización del divorcio, la modernización de la sociedad en materia educativa e infraestructural. En este sentido, es considerado pionero en la ampliación de las libertades y derechos de la ciudadanía.

151 Discurso pronunciado por Rafael Correa en Quito, 10 de agosto de 2009. Disponible en: https:// www.presidencia.gob.ec/wp-content/uploads/downloads/2013/10/10-10-09-

Discurso_posesion_Presidencial.pdf 
El entonces mandatario establecía, así, una correspondencia entre dos momentos de la historia nacional considerados fundacionales: la Revolución de 1809 que conquistó la soberanía política y la autodeterminación y la Revolución de 1909 que luchó por la integración nacional, un Estado secular y la imposición de límites al capital.

Pero habría sido solo bajo la RC que esas revoluciones encontraron su restauración salvadora, su último eslabón: “parafraseando a José Martí, (...) el trabajo libertario de Simón Bolívar, de Eloy Alfaro, está todavía por hacerse";152 "casi con periodicidad relojera, viene esta Revolución Ciudadana tratando de completar la obra de Alfaro, tratando de lograr nuestra segunda y definitiva independencia; y, realmente $\operatorname{lograr}(\ldots)$ esa igualdad de oportunidades para todas y para todos". ${ }^{153}$

No obstante, para Correa la historia se repetía: "la masacre del 2 de Agosto de 1810, la Hoguera Bárbara, el 30-S"154 en la medida que los enemigos de siempre -la prensa, la cúpula eclesiástica, el gran capital-155 continuaban obstaculizando la realización de un proyecto históricamente truncado, esto es, la revolución y, por consiguiente, el futuro de la patria:

152 Discurso pronunciado por Rafael Correa en Montecristi, 25 de marzo de 2011. Disponible en: https:// www.presidencia.gob.ec/wp-content/uploads/downloads/2012/10/2011-03-25-La-espada-de-AlfaroMontecristi.pdf

153 Discurso pronunciado por Rafael Correa en Quito, 17 de marzo de 2011. Disponible en: https:// www.presidencia.gob.ec/wp-content/uploads/downloads/2012/10/2011-03-17-Ley-de-Economia-Populary-Solidaria.pdf

154 Discurso pronunciado por Rafael Correa en Quito, 24 de mayo de 2011. Disponible en: https:// www.presidencia.gob.ec/wp-content/uploads/downloads/2012/10/2011-05-24-Centesimo-OctogesimoNoveno-Aniversario-189-de-la-batalla-del-Pichincha.pdf

La masacre del 10 de agosto de 1810 refiere a la revuelta ocurrida en la ciudad de Quito dirigida a liberar a los próceres que un año antes habían erigido la Primera Junta de Gobierno Autónomo; la respuesta de las autoridades fue la ejecución de los presos. La "hoguera bárbara" alude al asesinato e incineración pública de Eloy Alfaro Delgado en 1912. Finalmente, el "30-S" (30 de septiembre de 2010) da cuenta del intento golpista contra el gobierno de la RC tras una revuelta policial.

155 Son múltiples los discursos en donde Rafael Correa se refiere a los mencionados actores como "las fuerzas retardatarias" o "los poderosos" de la sociedad a quienes era preciso "derrumbar" o "desmitificar". Véanse los discursos pronunciados por Rafael Correa en Oxford, 26 de octubre de 2009 y en Quito, 10 de agosto de 2009. Disponibles en: http://webcache.googleusercontent.com/search? $\mathrm{q}=$ cache:hR HsuQB7YkJ:www.presidencia.gob.ec/wp-content/uploads/downloads/2013/10/2009-10-26EXPERIENCIA-COMO-CRISTIANO-DE-IZQUIERDA-OXFORDweb1.doc $+\& \mathrm{~cd}=1 \& \mathrm{hl}=$ en $\& \mathrm{ct}=\mathrm{clnk} \& \mathrm{gl}=$ ar\&client $=$ safari y https://www.presidencia.gob.ec/wp-content/ uploads/downloads/2012/10/10-08-09-Traspaso-Presidencia-Pro-tempore-UNASUR.pdf 
Bolívar fue acorralado y muerto a fuerza de soledad y de traiciones (...); el Mariscal de Ayacucho también fue asesinado para que no se realizaran los cambios necesarios. Jamás debemos olvidar que esa independencia fue secuestrada por las oligarquías criollas, a cuyos beneficios no fue convidado el pueblo llano (...) Cien años después la antorcha se hizo machete, se transformó en montonera (...). Pero tuvieron que pasar otros cien años para que la Revolución Ciudadana surgiera como un sueño colectivo (...). Podemos decir que el trabajo de Bolívar y de Alfaro estaba inconcluso, que la Patria había sido muchas veces traicionada (...). ${ }^{156}$

De modo que en la reelaboración de la memoria histórica propuesta por el Poder Ejecutivo ecuatoriano quedaba establecido una suerte de continuum de revoluciones "auténticas", superadoras unas de las otras y dirigidas todas ellas a conseguir una sociedad y un Estado cada vez más igualitarios e inclusivos, cuyo punto álgido se hallaba en el gobierno de la RC. Tres puntos distantes en el tiempo -bolivarianismo, alfarismo y correísmo- devinieron, así, momentos de rupturas simétricas que habilitaron un sistema calculado de semejanzas, encadenamientos y continuidades.

Aunque en menor escala, el mandatario ecuatoriano encontraba, asimismo, otra referencia histórica relevante en las actuaciones de dos mujeres "fraguadoras de la rebelión indígena en los páramos, como Dolores Cacuango y Tránsito Amaguaña”. ${ }^{157}$ Recordemos que, con Alfaro, éstos habían sido los únicos personajes de la historia del siglo XX ecuatoriano elegidos por el gobierno de la RC para ser representados en la "velada libertaria" del 9 de agosto.

Por otra parte, fue durante la posesión simbólica del mando presidencial -que tuvo lugar aquella mañana de 2009 en la localidad de Cayambe (donde nacieron, vivieron y/o actuaron dichas figuras)- cuando se inauguró, justamente, el Centro Intercultural Comunitario "Tránsito Amaguaña" en honor a la militante fallecida meses atrás:

Tránsito Amaguaña, nació para asumir las causas más justas para que llegaran los tiempos de equidad, nació Cayambi para el combate por su pueblo, para organizar

\footnotetext{
156 Discurso pronunciado por Rafael Correa en Quito, 10 de agosto de 2011. Disponible en: https:// www.presidencia.gob.ec/wp-content/uploads/downloads/2014/01/2011-08-10-Informe-a-la-Nacion.pdf

157 Discurso pronunciado por Rafael Correa en Quito, 6 de agosto de 2007. Disponible en: https:// www.cepal.org/sites/default/files/presentations/discursopresidenteecuador $0 . p d f$
} 
la conciencia, nació para aprender sus letras, la historia en contra de la opresión, para luchar contra la injusticia para organizar los primeros sindicatos agrarios $(\ldots)^{158}$

En este sentido, la reivindicación de las dos líderes y activistas indígenas -íconos del feminismo ecuatoriano por su papel central, a mediados del siglo XX, en las luchas indígenas y campesinas en la región serrana de Pichincha (Goetschel, 2006; Prieto y Guaján, 2013)- completaba, junto a la revolución alfarista, el selecto marco de referencia trazado por un gobierno que, de esa manera, se daba la misión de honrar, profundizar y concluir el trabajo afrontado previamente por cada una de estas personalidades ligadas a causas revolucionarias. 159

En Argentina, la exaltación que hizo el Poder Ejecutivo de los "patriotas" de Mayo también sirvió de puntapié inicial para el armado de un encadenamiento mayor de figuras individuales que, en palabras de la entonces presidenta, "dieron su vida por un proyecto colectivo de país y de nación”. 160

Así, en el videomapping proyectado sobre el Cabildo de Buenos Aires, al momento de dar cuenta de aquellas personalidades que -tras las guerras de independencia- habían contribuido a semejante obra, se destacaron los retratos de Juan Domingo Sarmiento y Juan Manuel de Rosas precedidos por uno de Facundo Quiroga; ligazón sumamente sugestiva que, sin dudas, se proponía diluir discordias y aunar al político sanjuanino en su faceta de intelectual y constructor de la escuela pública con el caudillo riojano emblema del federalismo y el gobernador de Buenos Aires que, en 1845, había defendido la soberanía nacional.

158 Discurso pronunciado por Rafael Correa en Cayambe, 9 de agosto de 2009. Fragmento disponible en: http://www.cubadebate.cu/noticias/2009/08/09/correa-toma-posesion-del-cargo-de-presidente-bajo-ritualindigena/\#.W9iOAy3SFmA

${ }^{159}$ Es posible rastrear discursos en los cuales Correa recuperó, en situaciones o contextos muy particulares, otras figuras relevantes de la escena moderna ecuatoriana, como por ejemplo en la X Conferencia Regional sobre la mujer de América Latina y el Caribe desarrollada en Quito en el 2007 cuando el entonces mandatario afirmó: "El Siglo XX entregó a la historia los nombres de Nela Martínez, de Alba Calderón, de Luisa Gómez de la Torre, de Matilde Hidalgo, de Berta Valverde, y tantas otras e innumerables madres coraje, compañeras de vida y de sueños". Sin embargo, ninguna de estas personalidades fue reivindicada durante las distintas posesiones presidenciales o conmemoraciones de fechas patrias. Véase: https://www.cepal.org/sites/default/files/presentations/ discursopresidenteecuador_0.pdf y

160 Discurso pronunciado por Cristina Fernández de Kirchner en Catamarca, 4 de junio de 2012. Disponible en: https://www.casarosada.gob.ar/informacion/archivo/25892-necesitamos-la-unidad-detodos-los-argentinos-para-nuestra-segunda-independencia-afirmo-la-presidenta 
Si nos remitimos a la publicidad oficial del festejo del bicentenario trasmitida por televisión, es posible observar en el comienzo de ésta un primer plano de Sarmiento mientras una voz en off afirma que, en doscientos años de historia, entre muchas otras cosas, también "educamos". ${ }^{161}$ Con respecto a la figura de Rosas, cabe recordar no solo la incorporación de su retrato dentro de la "Galería de los Patriotas Latinoamericanos", sino también el hecho de que una de las temáticas elegidas para el "Desfile de los 200 años" fue el combate de La Vuelta de Obligado, valioso episodio para algunas vertientes del revisionismo histórico que luego sería recogido por el peronismo -incluido el gobierno de Fernández de Kirchner- como símbolo de antiimperialismo y consolidación de la soberanía nacional. ${ }^{162}$ En palabras de la entonces mandataria:

estamos cubriendo una deuda histórica de los argentinos y de su historia cual es recordar una epopeya como fue la Vuelta de Obligado, oculta, premeditadamente ocultada desde hace 165 años por la historiografía oficial. En este lugar, donde hemos emplazado este monumento histórico, estas cadenas recuerdan a las cadenas que, por orden del brigadier general don Juan Manuel de Rosas, el general Lucio Mansilla y sus tropas cruzaron (...) en el río para que la flota anglofrancesa no pudiera pasar.

Corrían tiempos en los cuales, como en tantos otros tiempos de nuestra historia de estos 200 años, de este Bicentenario, potencias extranjeras querían dividir nuestro país y apoderarse de nuestros recursos (...) Por eso yo creo que el mejor homenaje

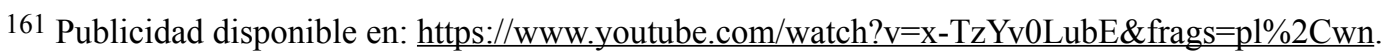
Por lo tanto, pareciera objetable la idea de que en los festejos del bicentenario argentino se produjo, como sostuvo Beatriz Sarlo (y recogió una parte considerable de la bibliografía relativa al tema), "la desaparición de hombres de la historia que no tienen condecoraciones en el santoral peronista: Sarmiento, por ejemplo". La Nación, 27 de diciembre de 2010. Disponible en: https://www.lanacion.com.ar/ 1336642-la-fuerza-de-lo-imprevisto

De hecho, la propia presidenta afirmaría tiempo después: "lo importante es (...) seguir caminando, avanzando, marchando para llegar a esa equidad que todos queremos y que, bueno, que durante 200 años distintos hombres y mujeres vinieron peleando. Hasta creo que Sarmiento (...) Miren que yo tenía una lectura de Sarmiento, viste, te ponen cosas de un lado y del otro. Porque, ojo, los revisionistas también me parece que algunas cosas...Y esta es una crítica a un sector muy querido para mí. La verdad que la historia hay contarla completa, en serio, toda, y que nos dejen hacer a nosotros, a cada uno de los argentinos nuestra propia evaluación”. Discurso pronunciado por Cristina Fernández de Kirchner en Buenos Aires, 12 de septiembre de 2012. Disponible en: https://www.casarosada.gob.ar/informacion/ archivo/26083-acto-de-anuncio-de-nuevas-medidas-de-gobierno-palabras-de-la-presidenta-de-la-nacion

162 Como sucedió con otros casos citados más arriba, la apelación a la figura de Rosas por parte del kirchnerismo tampoco constituyó una operación original. No solo porque se trata de un ícono que fue reivindicado tempranamente por ciertas vertientes del revisionismo histórico (Cattaruzza, 2003), luego recogido por Perón tras la Revolución Libertadora (Cattaruzza, 2003) y por el peronismo en su vertiente de derecha (Besoky, 2013) o neoliberal (Stortini, 2007; Schumway, 2010), sino porque las primeras consideraciones favorables a dicha figura y a la bandera del federalismo se remontan a los aportes y opiniones de algunos miembros de la llamada Nueva Escuela Histórica a finales de la década del '20 (Chiaramonte, 2001; Cattaruzza, 2003).
} 
que podemos hacer a estos hombres y mujeres en el Bicentenario (...) es, precisamente, entender la necesidad de la unidad nacional. No como un objetivo declarativo, sino como un instrumento para lograr definitivamente la construcción de una gran nación como soñaron Rosas, San Martín, Belgrano, Moreno, Castelli, Monteagudo (...) $)^{163}$

Si bien con menor protagonismo que el otorgado al gobernador de Buenos Aires vencido en Caseros, la incorporación de Quiroga a la narrativa sobre el pasado nacional desplegada durante la celebración bicentenaria dio cuenta de una mirada favorable al rol que los caudillos provinciales habrían tenido en la construcción de una organización federal, razón por lo cual debían figurar dentro del grupo de hombres que

defendieron el ideario nacional y popular ante el embate liberal y extranjerizante de quienes han sido, desde el principio de nuestra historia, sus adversarios, y que, en pro de sus intereses han pretendido oscurecerlos y relegarlos de la memoria colectiva del pueblo argentino. ${ }^{164}$

Sin embargo, este empeño por clarificar el pasado nacional se abocó, ante todo, a la tarea de realzar a "los dos grandes líderes populares del siglo XX": 165 Hipólito Yrigoyen y Juan Domingo Perón, los cuales, además de formar parte del repertorio de "patriotas" exhibido en la Casa Rosada, ocuparon un lugar destacado en el videomapping del bicentenario.

\footnotetext{
163 Discurso pronunciado por Cristina Fernández de Kirchner en San Pedro, 20 de noviembre de 2010. Disponible en: https://www.casarosada.gob.ar/informacion/archivo/22834-blank-34208821 Véase, asimismo, el Decreto $\mathrm{N}^{\circ} 1584$ del 2 de noviembre de 2010. Disponible en: http:// servicios.infoleg.gob.ar/infolegInternet/anexos/170000-174999/174389/texact.htm

${ }^{164}$ Decreto $\mathrm{N}^{\circ} 1880$ del 17 de noviembre de 2011 a partir del cual se estableció la creación del Instituto Nacional de Revisionismo Histórico Argentino e Iberoamericano Manuel Dorrego. Disponible en: http:// servicios.infoleg.gob.ar/infolegInternet/anexos/190000-194999/190107/norma.htm Si se tiene en cuenta el homenaje que realizó Fernández de Kirchner a Ángel Vicente Peñaloza en La Rioja en junio de 2010, la creación en el 2011 del aludido instituto -dirigido a "profundizar el conocimiento de la vida y obra de los mayores exponentes del ideario nacional, popular, federalista e iberoamericano", entre los cuales se incluía a Facundo Quiroga, Estanislao López, Francisco Ramírez, Felipe Varela, Juan Bautista Bustos y Ángel Vicente Peñaloza, entre otros- o el ascenso post mortem del caudillo catamarqueño Felipe Varela al grado de General del Ejército argentino en el 2012, pareciera que la irrupción de Facundo Quiroga en la narrativa histórica elaborada durante el bicentenario habría constituido un primer gesto dirigido a reivindicar a los caudillos federalistas del interior.
}

165 Discurso pronunciado por Cristina Fernández de Kirchner en Buenos Aires, 1 de julio de 2014. Disponible en: https://www.cfkargentina.com/homenaje-de-cristina-kirchner-a-peron-e-yrigoyen/ 
Es que, para la entonces presidenta, "el yrigoyenismo" había representado "la defensa irrestricta de los intereses del pueblo y de la nación", ${ }^{166}$ por lo cual no sorprende que en la producción audiovisual proyectada sobre el Cabildo haya aparecido el retrato de Yrigoyen junto a banderas argentinas y el logo de YPF, reivindicándose, mediante esa ligazón, al líder radical como el primer presidente en impulsar medidas en clave de nacionalismo económico $\mathrm{y}$, probablemente, en dar inicio a la tradición nacional-popular en la Argentina (Aboy Carlés, 2013).

En este eslabonamiento de individuos y movimientos "defensores del ideario nacional y popular", descollaba, desde luego, el peronismo ya que "con mayor profundidad, con mayor densidad (...) siguió ese legado histórico". ${ }^{167}$ De modo que, tras dar cuenta del golpe militar de 1930, resultó casi una "cuestión de lógica" que en la proyección se resaltara la figura de Juan D. Perón enlazada a una imagen de Eva Duarte de Perón mientras asomaban palabras como "pueblo", "plan quinquenal” y "bienestar", así como las siglas "CGT" e "YPF" sobre las cuales se alzaba el escudo del Partido Justicialista.

A diferencia de lo ocurrido al momento de reconstruir la etapa independentista, el sujeto femenino cobró una mayor presencia en las lecturas sobre el siglo XX efectuadas por el Poder Ejecutivo argentino. Proclamada por decreto "Mujer del Bicentenario", Eva Duarte devino la figura estelar de las puestas en escena del festejo conmemorativo, acaso, por representar "acabadamente, la imagen de las mujeres en la lucha por sus derechos". 168 En palabras de la entonces mandataria:

hablar de Eva es un poco hablar de la historia de la mujer en la política, es un poco también hablar de un sujeto nuevo no solamente desde el género, Evita no fue solamente género. Ella fue la verdadera creadora del concepto de justicia social, que vino a reemplazar el de caridad o beneficencia (...) Es que ella misma había sufrido esa injusticia desde muy chica, hija -en aquellos momentos calificado como extramatrimonial, casi una deshonra en la Argentina - mujer, artista y pobre. No le

\footnotetext{
166 Ibídem.

167 Ibídem.

168 Decreto $N^{\circ} 329$ del 8 de marzo de 2010. Disponible en: http://servicios.infoleg.gob.ar/infolegInternet/ anexos/160000-164999/164955/norma.htm
} 
faltaba nada para ser discriminada en la Argentina de aquellos años. Y pudo sobreponerse a todo eso y dejar una impronta, no ya en la historia de los argentinos, sino en la historia del mundo, Eva es un ícono de la Argentina. 169

En efecto, "Evita" no solo fue la única mujer escogida por el gobierno argentino para integrar la "Galería de los Patriotas Latinoamericanos", 170 sino que también adquirió un fuerte protagonismo en el videomapping -en donde su imagen aparece a la par de la de Perón, "esos dos gigantes de la historia"-, ${ }^{171}$ en la publicidad oficial de los festejos -donde se destaca un primer plano de ella mientras una voz en off sostiene que en doscientos años de historia "conquistamos derechos"-172 y en el "Desfile de los 200 años" - donde para simbolizar los "movimientos políticos y sociales" que marcaron la vida política del país, se representó una marcha de hombres y mujeres con pancartas que, entre otras consignas populares, rezaban "Perón cumple, Evita dignifica"-. 173

El otro sujeto cuyo rol en la historia nacional se vio, asimismo, distinguido -tanto en el videomapping como en el desfile del bicentenario- fue el de las Madres de Plaza de Mayo, las cuales serían honradas tiempo después -junto a las Abuelas de Plaza de Mayo- con el premio "Bicentenario de la Revolución de Mayo a los Derechos Humanos". ${ }^{174}$ Así, el gobierno de Fernández de Kirchner reinterpretaba al peronismo al colocar el acento en Eva Perón y las Madres (y, en menor medida, Abuelas) de Plaza de Mayo: "Mientras la figura de la primera aparece vinculada a lo popular, a los derechos sociales y también a la militancia setentista, la de las Madres y Abuelas ancla la

\footnotetext{
${ }^{169}$ Discurso pronunciado por Cristina Fernández de Kirchner en Buenos Aires, 26 de julio de 2010. Disponible en: https://www.casarosada.gob.ar/informacion/archivo/22440-blank-45659845
}

170 Es preciso recordar que las únicas dos mujeres que la acompañaron en esa exclusividad fueron Manuela Sáenz y Bartolina Sisa.

171 Ibídem.

172 Cabe señalar que tanto esta imagen como la incorporada a la "Galería de los Patriotas Latinoamericanos” coincidió con aquella que se volvió icónica en las banderas de la organización Montoneros. Véase: https://www.youtube.com/watch?v=x-TzYv0LubE\&frags=pl\%2Cwn

173 Véase: https://www.youtube.com/watch?v=a0nRASOTwAg

En relación a esta temática, también se buscó reponer -aunque de manera más indirecta y sin tanta resonancia- la lucha de las mujeres anarquistas contra el statu quo - cristiano, capitalista y patriarcal-a finales del siglo XIX y principios del XX, la cual fue representada en el desfile en cuestión con mujeres marchando bajo el lema "ni dios, ni amo, ni marido".

174 Decreto $N^{\circ} 1922$ del 9 de diciembre de 2010. Disponible en: https://www.argentina.gob.ar/normativa/ decreto-1922-2010-176300/texto 
narración a las demandas de justicia y memoria en los momentos de la recuperación de la democracia" (Patrouilleau, 2010: 50).

De modo que esta serie de coordenadas políticas e históricas aunadas y entramadas durante los festejos del bicentenario de Mayo se nutrió nuevamente de ciertos emblemas y figuras que la prédica nacionalista del revisionismo histórico había encumbrado aunque no por ello dejó de conservar el eco -sin dudas, más sutil y secundario- de otras tradiciones políticas y culturales de raigambre liberal-republicana. Con todo, es posible afirmar que el Poder Ejecutivo argentino buscó, como los demás, diseñar su propia genealogía de personalidades y/o acontecimientos precursores, de los cuales el kirchnerismo era, lógicamente, su punto de llegada.

Así lo sugirieron, por ejemplo, los últimos segundos del videomapping, los cuales -dirigidos a representar la etapa abierta tras su triunfo en el 2003- exhibieron un conjunto de imágenes que se iban superponiendo y acelerando de las Abuelas de Plaza de Mayo, de estudiantes de guardapolvo jugando en la escuela o con las netbooks del Plan Conectar-Igualdad, Néstor Kirchner removiendo los cuadros de Rafael Videla y Reynaldo Bignone de las paredes del Colegio Militar, Cristina Fernández asumiendo la presidencia, la anulación de las leyes de impunidad y primeros planos de Hugo Chávez, Rafael Correa y Lula da Silva, mientras suena una melodía épica y la voz de la presidenta despuntaba proclamando, a modo de síntesis, "hemos hecho muchas cosas juntos los argentinos". 175

En el caso venezolano, una vez establecida la trascendencia de la gesta emancipadora y la de los "300 años de batalla" previos, así como la necesidad de “terminar la independencia”, 176 la apelación a otros hitos del pasado nacional se vio -al igual que en Ecuador- restringida a unos pocos episodios y/o figuras que, de una manera u otra, habrían sido responsables de allanar el camino a la RB y, en función de eso, eran merecedores de ser destacados.

\footnotetext{
175 Videomapping disponible en: https://www.youtube.com/watch?v=soKm-7D7tnI

176 Discurso pronunciado por Hugo Chávez Frías en Caracas, 18 de abril de 2010. Disponible en: http:// www.todochavez.gob.ve/todochavez/637-intervencion-del-comandante-presidente-hugo-chavez-duranteprograma-especial-con-motivo-de-la-celebracion-del-bicentenario-del-inicio-de-la-gesta-independentistade-venezuela-el-19-de-abril-de-1810
} 
Sobre este modo de interpretar y recuperar la historia venezolana, resulta particularmente reveladora una conversación mantenida por cadena nacional de radio y televisión en las vísperas del bicentenario del 19 de abril, en la cual el entonces ministro del Poder Popular para la Cultura, Francisco de Asís Sesto, le explicaba al presidente el significado del "Monumento al 19 de abril":

Ministro del Poder Popular para la Cultura, Francisco Sesto Es como un edificio por dentro, tiene escaleras, tiene plataforma, es de alta tecnología y precisión, el otro día cuando estaban montando una de las piezas de acero pararon como 8 horas porque había una diferencia de 2 milímetros, es de una exactitud impresionante.

Presidente Chávez Una exactitud socialista.

Ministro del Poder Popular para la Cultura, Francisco Sesto Socialista.

Presidente Chávez Científica.

Ministro del Poder Popular para la Cultura, Francisco Sesto También los colores, Presidente, quisiera explicarle un momento la interpretación que le damos, por supuesto como obra de arte cualquiera puede interpretarlo como bien tenga, pero la que le dio la oficina suya, Presidente el suelo, la tierra, la pacha mama, representa el mundo que estaba aquí en la América, los pueblos originarios, después llega la historia que se empieza a escribir y es el primer segmento que es la oscuridad de la conquista y de la colonia, esa larga noche a la que usted se refería de 300 años de resistencia.

Después el rojo de la revolución de la independencia con Bolívar y (...) la traición de la oligarquía. (...)

Bueno viene la traición de la oligarquía, es esa oscuridad también y después llega la revolución bolivariana, que ya no se termina eso va hacia el infinito, hacia las estrellas.

Presidente Chávez del espacio ultraterrestre. Oye parece que los yanquis (...) están muy preocupados porque piensan que pudiera ser un cohete misilístico que tú montaste ahí, vamos aclararle a los yanquis para que no se preocupen, no es ningún cohete, bueno.

Ministro del Poder Popular para la Cultura, Francisco Sesto Es un cohete ideológico. ${ }^{177}$

177 Conversación entre Hugo Chávez Frías y Francisco de Asís Sesto en Caracas, 18 de abril de 2010 (resaltado en el original). Disponible en: http://www.todochavez.gob.ve/todochavez/637-intervencion-delcomandante-presidente-hugo-chavez-durante-programa-especial-con-motivo-de-la-celebracion-delbicentenario-del-inicio-de-la-gesta-independentista-de-venezuela-el-19-de-abril-de-1810 
Por lo tanto y con excepción de los tiempos de resistencia indígena, la guerra de independencia y la RB, el resto de la historia era concebida como una "era oscura" asociada principalmente a los tiempos del puntofijismo, ${ }^{178}$ en medio de la cual el Poder Ejecutivo venezolano eximía, en primer lugar, a Ezequiel Zamora, quien, de hecho, fue representado en una de las carrozas del desfile histórico del 30 de julio de 2011 en Caracas junto a un ejército de campesinos a fin de evocar la lucha por la tierra.

Es que, en palabras de Chávez, el líder de la rebelión popular de 1846 que, posteriormente, se enfrentó al bando conservador de José Antonio Páez en la llamada Guerra Federal, era "uno de los más grandes revolucionarios que ha parido esta tierra, uno de los más grandes luchadores por la justicia social, por la igualdad, un gran socialista". ${ }^{179}$

El otro "gran bolivariano" que el Poder Ejecutivo venezolano también rescató de la "oscuridad" fue el "general y presidente nacionalista" Cipriano Castro, 180 cuyo accionar se vio reivindicado durante el desfile histórico a través de una carroza dirigida a simbolizar los inicios de la era petrolera y recordar de qué manera "las apetencias de los imperios europeos" y "la mano oculta de (...) los Estados Unidos del norte" mancillaron -en alusión al bloqueo naval de finales de 1902- "la soberanía nacional". 181 En palabras de Chávez:

Cipriano Castro comenzó una revolución restauradora, era un gran bolivariano, lo echaron los yankis, lo echó el petróleo, lo echó la burguesía venezolana. Juan Vicente Gómez, que era compadrito de él y habían estado juntos en no sé cuántas guerras, pero fue comprado por la burguesía, comprado por los yankis, derrocó a Castro enfermo. Cipriano tuvo que ir a Europa a operarse de un riñón, y en su

\footnotetext{
178 En efecto, el ministro de Cultura ratificaba: "El primer tramo de color negro representa la colonización española; el segundo, de color rojo, la gesta independentista; el tercero negro, la era oscura del puntofijismo; y las tres rojas restantes, el triunfo de la Revolución Bolivariana y el poder popular del pueblo venezolano que se erige hacia el cielo y marca el infinito de la patria nueva". Disponible en: http:// albaciudad.org/2010/04/inaugurado-monumento-dedicado-al-19-de-abril/
}

179 Discurso pronunciado por Hugo Chávez Frías en Caracas, 20 de febrero de 2010. Disponible en: http://www.todochavez.gob.ve/todochavez/488-intervencion-del-comandante-presidente-hugo-chavezdurante-acto-de-homenaje-al-general-del-pueblo-soberano-ezequiel-zamora-y-promulgacion-de-la-leydel-consejo-federal-de-gobierno

180 Así lo caracteriza la voz en off que relataba el desfile histórico del 30 de julio de 2011. Véase: http:// albaciudad.org/2011/08/videos-y-fotos-asi-fue-el-desfile-bicentenario-independencia-para-siempre/

181 Ibídem. 
ausencia su compadre toma Miraflores sin disparar un tiro —era el Jefe del Ejército —, le manda un telegrama: "Compadre, no vuelva", y el compadre no pudo volver. Murió. En Puerto Rico murió, por cierto. Se vino al Caribe tratando de invadir Venezuela, pero ya enfermo. Murió a los pocos años (...) y Gómez entregó el país a los yankis. ${ }^{182}$

Por último, cabe resaltar que, si bien durante el desfile en cuestión el gobierno de Pérez Jiménez fue representado como "una dictadura militar prepotente" que llenó "de terror al país” y derrocó “a Rómulo Betancourt (...) primer presidente electo por voto universal y directo en Venezuela", 183 Chávez, en cambio, mantenía al respecto una opinión diferente. De hecho, el entonces mandatario prefería recordarlo como "el mejor presidente que tuvo Venezuela en mucho tiempo (...) mejor que Rómulo Betancourt”. Lo que sucedía, según Chávez, es que el general Pérez Jiménez solía ser condenado porque, al igual que él, “era militar”. 184

En consecuencia, la historia venezolana posterior a las guerras de independencia estuvo signada -salvo por el rol excepcional de algunas figuras militares, entre las cuales sobresalía Ezequiel Zamora- por la constante "traición de la oligarquía" y de las "burguesías apátridas" hasta que, finalmente, se produjo, al promediar el siglo XX, el triunfo de la RB que, como una suerte de acontecimiento redentor, vino a "seguir abatiendo cadenas" y “terminar la independencia". 185

El arribo de los bicentenarios de "independencia" devino una oportunidad para que los gobiernos de Bolivia, Ecuador, Argentina y Venezuela rearmaran las memorias

\footnotetext{
182 Discurso pronunciado por Hugo Chávez Frías en Cuba, 8 de octubre de 2010. Disponible en: http:// www.minrex.gob.cu/es/discurso-pronunciado-por-el-presidente-de-la-republica-bolivariana-de-venezuelahugo-rafael-chavez-f

${ }^{183}$ Véase: http://albaciudad.org/2011/08/videos-y-fotos-asi-fue-el-desfile-bicentenario-independencia-
para-siempre/

184 Discurso pronunciado por Hugo Chávez Frías en el programa de televisión Aló Presidente, 25 de abril de 2010. El video ha sido eliminado. Véase: http://laclase.info/content/video-chavez-alabo-al-dictadorfascista-perez-jimenez/
}

185 Discurso pronunciado por Hugo Chávez Frías en Caracas, 18 de abril de 2010 (negrita en el original). Disponible en: http://www.todochavez.gob.ve/todochavez/637-intervencion-del-comandante-presidentehugo-chavez-durante-programa-especial-con-motivo-de-la-celebracion-del-bicentenario-del-inicio-de-lagesta-independentista-de-venezuela-el-19-de-abril-de-1810 
históricas de cada nación y, en estrecha relación, sistematizaran sus filiaciones ideológicas. Esto supuso, naturalmente, que -junto con los mitos de orígenes- algunos pasajes de las historias nacionales de los siglos XIX y XX fueran privilegiados, restaurados y enlazados al presente de modo tal que les permitieran invocar un linaje heroico del cual aquellos habrían descendido.

Ahora bien, para conseguir eso fue necesario apelar, asimismo, a una antinomia central, la de amigo-enemigo, de la cual desprender un opuesto complementario, un "ellos" que posibilitara la constitución de un "nosotros", habilitando, así, ciertas exclusiones y jerarquías. Como es sabido, todo adentro exige un afuera: en cada uno de estos casos, la distinción del "enemigo" de la patria (la prensa, la cúpula eclesiástica, el gran capital o la oligarquía minera/latifundista, la burguesía apátrida y el imperialismo inglés o norteamericano) concurrió a la validación de un "nosotros político" asentado en distintas tradiciones y episodios históricos considerados altamente positivos, es decir, dignos de elogio y reivindicación.

Entre esos fragmentos del pasado y el presente se buscó tejer, así, una serie progresiva- de realizaciones singulares y/o revolucionarias que encontraban su síntesis en cada una de esas experiencias de gobierno. Una articulación cronológica y genealógica de figuras y acontecimientos históricos que se vieron reapropiados y modelados como una totalidad unitaria, otorgándole un sentido y una dirección. Diacronías que, sin embargo, fueron más allá de la mera sucesión empírica al contenerse y condensarse en unos presentes que se exhibían como únicos y auténticos; episodios que no solo eran realizaciones del pasado, sino que también eran -por todo aquello que no habían llegado a ser- potencia para el presente.

\section{Latinoamericanismo y antiimperialismo en la narrativa bicentenaria}

Estas tentativas por revisar las memorias históricas nacionales y sistematizar sus filiaciones ideológicas involucró, asimismo, una reactivación y exacerbación del relato 
bolivariano de la "patria grande", emblema de la identidad y unión continental. Así, un punto más aparente -aunque no por ello menos significativo- de las narrativas trazadas durante los bicentenarios de "independencia" fue su perspectiva plurinacional, latinoamericanista y antiimperialista basada en la reivindicación de un conjunto de figuras, ideas y movimientos -tan emblemáticos como heterogéneos- de la historia regional.

Portavoces de la revolución, el antiimperialismo, el socialismo, la "cuestión nacional", la unidad latinoamericana y/o los derechos humanos como François Toussaint-L'Ouverture, Alexandre Pétion, José Martí, Francisco Morazán, Emiliano Zapata, Augusto Sandino, Juan Carlos Mariátegui, Fidel Castro, Ernesto Guevara, Salvador Allende, Rigoberta Menchú o Hebe de Bonafini, entre muchos otros, se vieron incorporados al altar de los héroes que cada gobierno había ido restaurando en tiempos de bicentenario y, junto con los respectivos "padres fundadores", fueron rememorados en su faceta de "integracionistas, humanistas profundos, seres de luz, de alma grande, de amor de Patria inmensa americana". ${ }^{186}$

La recuperación de las grandes narrativas latinoamericanas del siglo XIX y XX y la exaltación de figuras consideradas heroicas y míticas -en un sentido mariateguianopuede ser enmarcada en una inquietud clásica del devenir de la región: la necesidad de precisar el "ser latinoamericano", lo cual ha involucrado, en distintos momentos históricos, una apelación a la antinomia imperialismo-antiimperialismo. ${ }^{187}$

En este sentido, las transformaciones políticas de signo progresista que empezaron a producirse a comienzos del siglo $\mathrm{XX}$ en la región habilitaron un nuevo campo de

\footnotetext{
186 Discurso pronunciado por Rafael Correa en El Salvador, 1 de junio de 2009. Disponible en: http:// www.uca.edu.sv/noticias/imprimir-texto.php?texto $=735$

187 Como apuntaba Aldo Marchesi: "De una manera general, podemos decir que durante el siglo XX al menos tres momentos marcaron cambios importantes en los significados de la antinomia Imperioantiimperialismo. El comienzo del siglo, donde el progresivo protagonismo de EE.UU. y el alejamiento de Inglaterra generaron múltiples discusiones acerca de los riesgos y beneficios del nuevo mapa internacional en términos culturales, económicos y políticos. Este primer momento no necesariamente fue visto como una amenaza, sino como una oportunidad para la modernización, especialmente para sectores medios que estaban emergiendo en algunos países de la región. El ascenso de los populismos desde los 40 con sus diversas variantes de izquierdas y derechas tendió a marcar una polarización entre la nación y lo extranjero, expresada en el relato histórico, y en los proyectos económicos y sociales. Y por último, la década de los 60 y los 70 que, con la constatación del fracaso de las experiencias desarrollistas y populistas con el telón de fondo de la guerra fría, reformuló el antiimperialismo en una perspectiva más radicalizada, donde la emergencia de la revolución cubana representó para diversos intelectuales el camino para una modernización latinoamericana alternativa al capitalismo" (2006: 136-137).
} 
posibilidades para repensar y representar la relación entre cada una de estas naciones y las potencias hegemónicas de turno $\mathrm{y}$, en última instancia, para formular una nueva noción de antiimperialismo que, combinando y aggiornando elementos de las versiones anteriores, permitiera reafirmar la autonomía (así como la capacidad de agencia) nacional y regional sin que ello implicara una vocación anticapitalista ni una real desconexión de los países centrales (Lomnitz, 2006; Arditi, 2008).

Esto supuso ciertamente un retorno a símbolos e ideas de larga data asociados a la tradición o imaginario antiimperialista como la categoría de segunda independencia o la bandera de unidad continental, convertidas en componentes centrales de los discursos políticos de cada Poder Ejecutivo en cuestión. En palabras de algunos mandatarios:

Mas nunca Venezuela será colonia yanqui ni colonia de nadie. Llegó la hora definitiva de nuestra verdadera independencia doscientos años después. Y no solo de la independencia de Venezuela, porque (...) no sería posible sin la independencia de nuestra América, de la América Latina y el Caribe (...) ${ }^{188}$

(...) finalmente el año 1825 llega la fundación con el Libertador Simón Bolívar; y aquí estamos reunidos para garantizar la segunda independencia, la verdadera liberación del pueblo boliviano. 189

este Bicentenario de 1810 encuentra a los pueblos de la América del Sur en una nueva etapa de transición y en lo que yo denomino la Segunda Independencia, porque nos encuentra a todos los hombres y mujeres con fórmulas y pensamientos de inspiración propia, que se han elaborado por nosotros mismos en materia económica, política, social, que, al igual que aquellos hombres, persiguen la liberación de nuestros pueblos y la unidad de nuestra región, siempre respetando nuestras diferencias y la pluralidad de nuestras identidades. 190

La urgencia por conseguir aquella unión frustrada durante la "primera independencia" y -como veremos con mayor profundidad en el capítulo siguiente- de

\footnotetext{
188 Discurso pronunciado por Hugo Chávez Frías en Caracas, 19 de abril de 2010. Disponible en: https:// www.youtube.com/watch?v=LQv8yHiP go

${ }^{189}$ Discurso pronunciado por Evo Morales en La Paz, 7 de febrero de 2009. Disponible en: http:// www.apoyobolivia.net/discurso-evo-morales

190 Discurso pronunciado por Cristina Fernández de Kirchner en Caracas, 19 de abril de 2010. Disponible en: http://matrizur.org/2010/04/video-presidenta-cristina-fernandez-qel-bicentenario-encuentra-asuramerica-en-su-segunda-independenciaq/
} 
erigir a la región como sujeto fuerte contra los centros imperiales y a favor de un ordenamiento global democrático y multipolar fue sustentada y acompañada de una representación mitificadora del pasado latinoamericano, una suerte de memoria histórica "monumental" que revivía y consumaba los sueños de aquellos héroes:

\begin{abstract}
"Para nosotros, la Patria es América", dijo Bolívar, y aquella sentencia que parecía utópica, o siempre traicionada por la resignación o sumisión de los gobiernos del continente a los poderes omnímodos, se está haciendo realidad. ${ }^{191}$
\end{abstract}

\begin{abstract}
Ahora, estamos de pie frente a la historia para decirles a nuestros próceres que sus esfuerzos no fueron vanos ni sus sacrificios perdidos, porque nosotros, sin olvidar su memoria, estamos también dispuestos a combatir por un sueño, el de una Latinoamérica unida por el ideal de la igualdad, la libertad y la justicia. ${ }^{192}$
\end{abstract}

No hay poderío militar, no hay poderío económico que pueda con un pueblo cuando éste decide liberarse y yo creo (...) que ese es el mensaje que nos dan esos hombres y esas mujeres que enfrentaron al ejército más poderoso en aquel momento, en 1810 y el mensaje es que lo que define la libertad de los pueblos (...) es el valor y el coraje que tengan sus ciudadanos para defender los sagrados derechos de la libertad y de la igualdad. 193

En cuanto a quiénes fueron aquellos "hombres y mujeres" que enarbolaron la bandera de una "Latinoamérica unida", resulta esclarecedor el manifiesto final de la IX Cumbre del ALBA realizada en Caracas en ocasión del bicentenario de la Revolución del 19 de abril, donde los países firmantes reivindicaron

la monumental obra encabezada por próceres como Bartolina Sisa, Tupac Amaru, Tupac Katari, Guaicaipuro, Miranda, Bolívar, Sucre, Manuela Sáenz, San Martín, O'Higgins, Petión, Hidalgo, Sandino, Morazán, Artigas, Alfaro, Toussaint

\footnotetext{
191 Discurso pronunciado por Rafael Correa en Quito, 16 de febrero de 2011. Disponible en: https:// www.presidencia.gob.ec/wp-content/uploads/downloads/2012/10/2011-02-16-Condecoracion-EmbajadorCarlos-Pineiro.pdf

192 Discurso pronunciado por Lenin Moreno en Quito, 24 de mayo de 2010. Disponible en: https:// www.presidencia.gob.ec/wp-content/uploads/downloads/2014/01/24-05-10-Discurso-del-VicepresidenteLM-por-conmemoracion-victoria-Pichincha-y-homenaje-Gnrl.-Manuela-Saenz.pdf

193 Discurso pronunciado por Cristina Fernández de Kirchner en Caracas, 19 de abril de 2010. Disponible en: http://matrizur.org/2010/04/video-presidenta-cristina-fernandez-qel-bicentenario-encuentra-asuramerica-en-su-segunda-independenciaq/
} 
L'Ouverture y Martí, nuestros Libertadores, en la conquista de la independencia contra el colonialismo en el siglo XIX.

En tanto

Su lucha ha servido de modelo político y ético para la continuación de obra emancipadora. Su ejemplo ha sido la guía para el renacimiento en el seno de los pueblos "Nuestro americanos" de una nueva conciencia y fuerza emancipadora de nuestras patrias, que (...) completarán la tarea iniciada hace 200 años, retomando la senda libertaria. 194

De igual modo, la "Galería de los Patriotas Latinoamericanos" inaugurada el 25 de mayo de 2010 en Buenos Aires también contribuyó al trazado de ese panteón o genealogía de grandes figuras heroicas y/o revolucionarias de la historia latinoamericana que, en palabras de la mandataria argentina, "en los últimos 200 años abonaron con su sangre sus ideales de una América del Sur más democrática, con libertad pero para la igualdad (...)". 195

La muestra permanente en cuestión fue resultado de una invitación por parte del Poder Ejecutivo argentino a que los presidentes de América Latina enviaran los retratos de aquellos personajes considerados fundamentales para el derrotero de sus historias nacionales en una suerte de gesto simbólico que diera cuenta de la voluntad integracionista y latinoamericanista del primero.

Así, se destinó un salón de la Casa Rosada para exhibir los óleos y fotografías de las siguientes figuras: Simón Bolívar, Francisco de Miranda y Antonio José de Sucre (por el gobierno venezolano); Tupac Katari, Bartolina Sisa y Pedro D. Murillo (por el gobierno boliviano); Joaquim José da Silva Xavier “Tiradentes” y Gétulio Vargas (por el gobierno brasileño); José Martí, Fidel Castro y Ernesto Guevara (por el gobierno cubano); José María Morelos, Benito Juárez, Emiliano Zapata, Pancho Villa y Lázaro Cárdenas (por el gobierno mexicano); José Gervasio Artigas (por el gobierno

\footnotetext{
${ }^{194}$ Manifiesto Bicentenario de Caracas. Declaración Final de la IX Cumbre del ALBA. Disponible en: http://sedici.unlp.edu.ar/bitstream/handle/10915/48876/ Manifiesto_Bicentenario_de_Caracas abril_2010 6 $\quad$ p. . pdf? sequence $=3$

195 Discurso pronunciado por Cristina Fernández de Kirchner en Buenos Aires, 25 de mayo de 2010. Disponible en: https://www.perfil.com/noticias/politica/el-discurso-completo-de-cristina-kirchner-por-elbicentenario-20100525-0038.phtml
} 
uruguayo); Francisco Solano López (por el gobierno paraguayo); Agustín Farabundo Martí y monseñor Romero (por el gobierno salvadoreño); Augusto César Sandino (por el gobierno nicaragüense); Juan José Arévalo Bermejo y Jacobo Arbenz Guzmán (por el gobierno guatemalteco); Francisco Morazán (por el gobierno hondureño); Antonio Nariño (por el gobierno colombiano); Tupac Amaru y Víctor Haya de la Torre (por el gobierno peruano); Alexandre Pétion (por el gobierno haitiano); Juan Rafael Mora Porras (por el gobierno costarricense); Eugenio Espejo, Manuela Sáenz y Eloy Alfaro (por el gobierno ecuatoriano); Omar Torrijos (por el gobierno panameño); y Bernardo de O’Higgins y Salvador Allende (enviado el primero por el entonces mandatario chileno Sebastián Piñera y el segundo por Michelle Bachelet). ${ }^{196}$

Este conjunto de referentes de la integración latinoamericana -“que, más que una causa justa, política, es un árbol frondoso de raíces profundas, una clave de identidad que desborda fronteras"-197 podía, no obstante, experimentar algunas modificaciones según el caso. Por ejemplo, el Poder Ejecutivo ecuatoriano incorporaba otras figuras, algunas de ellas contemporáneas, en un intento por aglutinar y hermanar múltiples causas y figuras del pasado y el presente de la región:

Porque Manuela Sáenz y Antonio José de Sucre, porque José Martí y Emiliano Zapata, porque Eloy Alfaro y Augusto César Sandino, porque Manuel Rodríguez y José Carlos Mariátegui, porque Antonio Macero (sic) y Máximo Gómez y porque todos los patriotas del continente se consagraron [a] la liberación de nuestra patria grande cobijados por la imagen y la bandera de Bolívar (...).

Afortunadamente América Latina no pertenece, hoy, a ningún imperio. Los herederos de José Artigas, José de San Martín, Rosa Campusano, Miguel Hidalgo y también de Rigoberta Menchú, Camilo Torres, Leonidas Proaño, Hebe de Bonafini; no creemos en el pensamiento único, porque nuestra identidad tiene el rostro de todos y de todas. 198

\footnotetext{
196 Junto a las personalidades elegidas por el gobierno argentino, estos fueron los 43 retratos originales a los cuales se sumaron posteriormente las imágenes de Néstor Kirchner y Hugo Chávez tras sus respectivos decesos. Por otro lado, cabe señalar que el único "patriota” puesto en vida fue Fidel Castro.

197 Discurso pronunciado por Rafael Correa en Quito, 15 de abril de 2010. El discurso ha sido eliminado de la web. Última consulta: 19/03/2016.

198 Discurso pronunciado por Rafael Correa en La Habana, 8 de enero de 2009. El discurso ha sido eliminado de la web. Última consulta: 7/03/2016.
} 
En el caso venezolano, las raíces de este panteón incluso trascendían las fronteras y los siglos en la medida que el linaje antiimperialista, del cual la RB era su punto de llegada, comenzaba, según Chávez, con

un viejo tipo (...) tan viejo como que tiene 20 siglos ya. Cristo uno de los más grandes luchadores antiimperialistas de la historia del mundo, el verdadero Cristo, el Redentor de los pobres (...) uno anda inspirado también, en otros tipos no tan viejos (...) Ahora esos viejos tipos han vuelto por ahí, han vuelto, uno de esos viejos tipos cuando estaba muriendo lo estaban asesinando, lo estaban picando en pedazos (...) cuando el sintió que estaba muriendo ya, no aguantaba, lanzó un grito una consigna, dijo: "Hoy muero" les dijo a los imperialistas que lo mataban "Hoy muero pero algún día volveré, hecho millones" ha vuelto Atahualpa hecho millones, ha vuelto Túpac Amaru, hecho millones, ha vuelto Bolívar hecho millones, ha vuelto Sucre y Zapata hecho millones (...) Y aquí estamos nosotros, ellos han vuelto con nosotros. ${ }^{199}$

De esta manera, y más allá de los posibles matices y variaciones de caso, los cuatro Poderes Ejecutivos ratificaron, durante las celebraciones bicentenarias, la apuesta por encarnar y ostentar discursivamente esa sensibilidad antiimperialista $\mathrm{y}$ latinoamericanista y, en estrecha relación, instalarse ellos mismos como los auténticos herederos e intérpretes del legado político y cultural de aquel conjunto -diverso, extravagante y contingente- de figuras "patriotas" de la historia y el presente latinoamericano.

La adopción y el uso de esos valores y personajes -muchos de ellos emblemas de las izquierdas latinoamericanas- se constituyó en un elemento retórico ineludible para unos actores que, en ese empeño por restaurar las memorias históricas de cada nación en clave latinoamericanista, estaban, entre otras cosas, intentando erigirse como los más legítimos, fieles y, sobre todo, viables exponentes del resurgimiento de la izquierda en la región. En ese sentido, que se presentaran como los responsables de traer al presente a aquellos "viejos tipos" -y, podría pensarse, "viejos" topos, también- resultaba no menos que una operación coherente con sus aspiraciones políticas e identitarias.

199 Discurso pronunciado por Hugo Chávez Frías en Porto Alegre, 31 de enero de 2005. Disponible en: http://www.todochavez.gob.ve/todochavez/3661-v-foro-social-mundial-el-sur-norte-de-nuestros-pueblos 


\section{En busca de un linaje perdido. Primeras consideraciones provisorias}

En El problema de la conciencia histórica Gadamer observaba que ésta "no oye más bellamente la voz que le viene del pasado, sino que, reflexionando sobre ella, la reemplazará en el contexto donde ha enraizado, para ver en ella el significado y el valor relativo que le conviene", denominando a este "comportamiento reflexivo cara a cara de la tradición” como "interpretación" (1993: 43). Es quizás en este sentido que los Poderes Ejecutivos de Bolivia, Ecuador, Argentina y Venezuela se sumergieron en el pasado, en ocasión de los bicentenarios de "independencia", a fin de recobrar, interpretar y exhibir aquel abanico de tradiciones, figuras y acontecimientos singulares como sus marcas fundadoras, las cuales - por sus posibles significados, relevancia histórica y/o raigambre en la cultura popular- les concedían a los primeros la posibilidad de ajustar, nutrir y validar sus idearios, búsquedas e intereses políticoideológicos.

Ante todo, los levantamientos indígenas y/o las gestas de independencia fueron elevados al rango de linaje y presentados como condición de posibilidad y fundamento de estas experiencias de gobierno. Así, cada una de ellas procuró obtener "su legitimidad y valor de la perdurable intimidad" que supuestamente las unía a un "no-ya mítico" (Virno, 2003: 182), esto es, a aquellos actos inaugurales y legendarios -a la vez, cercanos y presentes- conforme lo fueron las ya mencionadas rebeliones indígenas o revoluciones políticas de independencia.

Esta búsqueda dirigida a recobrar y conectar fragmentos valiosos de la historia para ser explotados como potencia para el presente comprendió, asimismo, otros episodios y personajes de las historias nacionales distinguidos por haber procurado continuar, a ojos de nuestros protagonistas, los esfuerzos emancipadores. De esta manera, fueron representados como momentos o pasajes intermedios -nuevamente, frustrados e incompletos- entre aquellos acontecimientos originales y las experiencias gubernamentales en ese momento vigentes reveladas, a fin de cuentas, como sus más promisorios puntos de llegada. 
Por último, el color regional que se buscó imprimir a la narrativa bicentenaria fue uno de los modos en que el relato bolivariano de la "patria grande" se vio restaurado y entroncado con los proyectos políticos en cuestión. Esta construcción discursiva del pasado que, como antaño, revistió fines materiales -que más adelante consideraremos-, así como simbólicos e identitarios -en la medida que les permitió asumirse y presentarse como los auténticos sucesores de ciertas tradiciones y causas revolucionarias más generales de la historia latinoamericana- constituyó otros de los rasgos centrales de los usos del pasado efectuados durante los bicentenarios.

Por medio de este proceso de reapropiación, restauración y representación del pasado nacional y regional, los Poderes Ejecutivos delinearon, entonces, sus filiaciones ideológicas, asumieron su simbología e intentaron afianzar sus proyectos políticos e ideas de nación; todo ello a partir de un entrecruzamiento de ideologías, imágenes y discursos cuyas disonancias, ambivalencias y contradicciones recuerdan, como sostenía Eric Hobsbawm (1996), que las identidades no son construcciones fijas ni coherentes, y que, mientras nada dicte lo contrario, pueden convivir, combinarse y mantenerse en paralelo. 


\section{Capítulo III}

\section{Los repertorios festivos del bicentenario. Formas, propósitos y significados}

Los dispositivos a partir de las cuales fueron celebradas, ritualizadas y escenificadas las identidades nacionales a lo largo del tiempo se han vuelto -como fue posible advertir en la introducción de este estudio- una preocupación central entre historiadores y cientistas sociales desde hace ya varias décadas. Es que la reflexión sobre los repertorios festivos -y sus formas estéticas, simbólicas y culturales- se reveló, una y otra vez, como un efectivo punto de entrada para discurrir en torno a los modos en que las sociedades (re)organizaban y (re)definían su universo socio-cultural, al tiempo que les permitía aproximarse -desde un ángulo distinto- a los hechos y procesos políticos que estaban sucediendo en cada momento histórico.

Este capítulo recoge aquella misma preocupación: se pregunta, entonces, por las puestas a punto de los festejos del bicentenario, esto es, se detiene y profundiza en el tipo específico de prácticas festivas y conmemorativas desplegadas por los cuatro Poderes Ejecutivos a fin de proseguir con el análisis de los intentos oficiales por celebrar la nación, restaurar ciertas identidades colectivas y legitimar sus proyectos políticos.

Así como en el capítulo anterior observamos de qué manera estos gobiernos reconstruyeron el pasado nacional y regional con el objetivo de forjar linajes y narrativas históricas que sirvieran de sustento a sus pretensiones por revisar las representaciones dominantes de la nación, al tiempo que se erigían como los responsables de llevar a cabo la "segunda" independencia, el recorrido por los dispositivos y escenarios festivos y conmemorativos que sigue a continuación servirá, 
asimismo, para continuar reflexionando sobre esas (y otras) aristas político-ideológicas que rodearon a los mismos.

Ahora bien, el análisis de estas puestas en escena no pretenderá dar únicamente cuenta de la materialización o representación ritual de un proyecto ideológico, sino también examinar los festejos patrios en tanto "formas condensadas de sociabilidad" (Bisso, 2009: 99), en donde la recuperación de la dimensión lúdica-festiva permita complejizar y matizar el predominio de lo ideológico en el conjunto de prácticas que estos actores políticos buscaron desplegar durante las celebraciones bicentenarias.

\section{Las liturgias políticas de los bicentenarios}

\section{Desfiles militares}

Diversos actos institucionales, así como rituales cívicos y religiosos de larga duración fueron dando forma a las liturgias políticas de los bicentenarios. Un ejemplo de ellos lo constituyeron los desfiles y las marchas militares, los cuales -con mayor o menor protagonismo- formaron parte sin excepción de las cuatro agendas conmemorativas. Aunque este rito conmemorativo ha sido desde siempre un rasgo 
distintivo de las fiestas patrias posrevolucionarias en América Latina, 200 en esta ocasión el tradicional elemento castrense buscó ser recuperado y reactualizado de modo que encarnara y reflejara sentidos más afines con las problemáticas, exigencias y búsquedas políticas de los gobiernos de turno.

En el caso de Bolivia, las paradas militares tuvieron un lugar central en los dos aniversarios patrios. Tras el desfile cívico-militar desarrollado el 25 de mayo de 2009 en El Villar en homenaje a Juana Azurduy, Manuel Ascencio Padilla y Tomás Katari -que, al compás de la chacarera "La Patria" llevada a ritmos marciales, había congregado a la caballería y la banda escolar, campesinos e indígenas, las Fuerzas Armadas y la Policía Nacional-, una nueva puesta en escena de naturaleza marcial era la elegida para dar inicio a la celebración de los 200 años de la Junta Tuitiva de Gobierno en La Paz.

De esta manera, el 13 de julio una marcha de caballería, que tenía como destino final a la capital boliviana, partía desde El Villar hacia la localidad andina de Patacamaya, parada intermedia elegida por el primer mandatario y su equipo de gobierno para inaugurar oficialmente la semana del bicentenario. Allí, luego de hacer gala de la presencia de mandatarios, miembros de las Fuerzas Armadas e indígenas de distintos países de América Latina, Morales aprovechó para destacar que:

Como siempre La Paz, (...) es el centro de integración no solamente de los bolivianos sino de todos los latinoamericanos. Y La Paz nuevamente debe

\footnotetext{
200 Cabe reparar, a modo de ejemplo, en las memorias de la escritora argentina María Rosa Oliver, quien -al evocar cómo percibía de niña, a principios de siglo XX, el tradicional desfile militar del 25 de mayoescribía: "Apretándonos el cráneo entre los barrotes de hierro en forma de lanzas cruzadas y con olor a frío, queremos ver, apenas asome por la esquina de Florida, la banda cuyos acordes la anuncian, haciendo volverse, como un viento inclina a un trigal, todas las cabezas hacia un mismo lado. Los vigilantes abren paso a las tropas, empujando el cerco humano hasta ponerlo en línea. Y aunque los vigilantes son los heraldos del desfile, los chicos estamos en contra de ellos.

Comienza el chistido elástico, monótono de la infantería; el rodar enervante y duro de la artillería que huele también a hierro frío; el golpear de cascos ágiles entrecortado de relinchos, de la caballería y el sonar de los clarines lúgubres, de las cornetas agudas, de los platillos chillones y de los tristes tambores, y todo se convierte pronto en un arrullo sordo, hipnótico que me alarga los párpados hacia las sienes, tirantes ya entre los fierros de la baranda. (...)

Pasan y pasan soldados, caballos, cureñas. Pasan hasta perderse cuadras más adelante en un polvo de oro, banderas, banderines y lanzas.

-Son tacuaras - explica papá (...)

-Y los caballos también son bien criollos -agrega el tío cuya afición por lo autóctono supera a la de pellizcar nalgas femeninas.

No a él, sino a mi abuelo, papá dice:

- ¿Se acuerda, doctor? Antes casi todos los soldados eran morenos.

- Sí, pero los inmigrantes, la conscripción...

- Han aclarado las filas -concluye mi padre, con el tono objetivo de quien ignora el racismo." (1995

[1965]:141-142)
} 
demostrar, hermanas y hermanos, esa hermandad (...) esa amabilidad con los visitantes, esa hospitalidad, como siempre (...)

Si realmente Sudamérica aprovecha muy bien sus recursos naturales (...) yo siento que Sudamérica es una gran esperanza para todo el mundo (...) Aunque siempre habrá provocaciones, algunas familias no quieren la igualdad entre todos nosotros, no quieren que los pobres nos levantemos o mejoremos nuestra situación económica o social. Es una batalla, un debate permanente pero finalmente cuando los pueblos se organizan (...) se pueden resolver esas demandas, para algunos desde hace 500 años atrás, para algunos desde hace 200 años atrás y para todos los bolivianos demandas desde hace veinte años del neoliberalismo (...) estamos librando esa batalla (...) Sin embargo, esta semana estamos de fiesta del bicentenario (...) Doscientos años es una sola vez (...)201

De este modo, en lo que puede ser interpretado como una reformulación de la narrativa del país de contactos surgida, hacia mediados de la década del 30, como doctrina geopolítica formal,202 Bolivia no solo era presentada como un espacio clave en la nueva etapa de integración política y económica latinoamericana iniciada hacia principios del 2000 en rechazo a las medidas neoliberales del Consenso de Washington, sino que La Paz - por su centralidad geográfica en el subcontinente, pero también por su carácter precursor en las luchas de independencia- debía encontrarse en el corazón del mencionado proyecto. Al declarar a la capital andina como el "centro de integración" de Bolivia y de América Latina y al remarcar -en un claro guiño a los episodios violentos ocurridos en Sucre un año atrás- la "amabilidad" y "hospitalidad" de ésta, el mandatario reafirmaba, así, la superioridad y el valor de La Paz no solo en términos geopolíticos, sino también morales.

Finalizado el discurso y con una bandera de Bolivia en su mano y un gran collar

\footnotetext{
201 Discurso pronunciado por Evo Morales en Patacamaya, 13 de julio de 2009. Disponible en: https:// www.youtube.com/watch?v=ZGlm64C-NJ0

202 Según Perrier Bruslé (2015), la denominada narrativa del país de contactos se vio consolidada como doctrina geopolítica formal por el entonces canciller de Bolivia, Luis Fernando Guachalla. Para ello, el canciller retomó a los pensadores del territorio de principios del siglo XX, entre los cuales se encontraba Jaime Mendoza, quien sostenía que el enclaustramiento y la pérdida de la mitad del territorio desde su independencia hasta la guerra del Chaco hicieron de Bolivia un "país tambaleante". En este sentido, Guachalla consideraba que su existencia solo podría asegurarse mediante la inserción del altiplano en el continente como lugar estratégico - o "heartland"- capaz de arbitrar los intercambios económicos y la comunicación entre sus vecinos, así como contribuir al equilibrio continental como espacio neutro entre las dos potencias de Sudamérica, Brasil y Argentina. De modo que este dispositivo discursivo surgía, en aquel entonces, con el propósito de encontrarle "utilidad" a Bolivia para asegurar y justificar su permanencia y autonomía.
} 
de flores que colgaba de su cuello, el mandatario se montó sobre un caballo blanco ¿alusivo, quizás, a los corceles de los próceres?-y, acompañado por el vicepresidente, el ministro de Defensa, militares y campesinos, encabezó - por una corta distancia y rodeado del público ahí reunido- la cabalgata de 240 jinetes que ahora partía rumbo a La Paz, donde tres días después se llevarían a cabo los actos principales del bicentenario.

Allí, la "Parada cívico-militar Bolivariana de los Pueblos" -a saber, un desfile donde los movimientos sociales afines al gobierno marcharon junto a tropas de Argentina, Bolivia, Ecuador, Perú y Venezuela hacia la Plaza Villarroel- fue la ocasión elegida por Morales para volver a pronunciar ante la ciudadanía un mensaje de fuerte contenido nacionalista, latinoamericanista y antiimperialista:

Queremos decirles acá, para quienes piensan que América es para los americanos, América es para los pueblos liberados y no para los americanos. Estamos en nuevos tiempos, nuevo milenio y este milenio es de los pueblos y no de los imperios quienes piensan someternos para saquear nuestros recursos. Tupac Katari dijo: "yo muero y volveré en millones". Ahora somos millones, hermanos y hermanas. Murillo dijo en 1809 la tea que dejó encendida nadie la podrá apagar por eso la lucha sigue. Una vez escuché lo que decía Chávez sobre el mensaje de Simón Bolívar (...) que Estados Unidos parece destinado por la providencia a plagar la América de miseria en nombre de la libertad. Bolívar, el gran libertador de cinco países ya nos había advertido que so pretexto de la libertad plagarían de hambre y miseria a América. Este mensaje es para reflexionar en lo económico, social y cultural, ideológico; para garantizar la segunda y verdadera liberación de los pueblos de América Latina y por eso la presencia de mineros, la clase media intelectual, la presencia de las Fuerzas Armadas, de los pueblos de Latinoamérica, es el símbolo de unidad para acabar con los imperios de aquí en adelante.

A nombre de los que lucharon, que dieron su vida, a nombre de esas fuerzas sociales, quiero decirles que nunca más imperios que vengan a dominar a Latinoamérica y nunca más intereses regionalistas que puedan dificultar transformaciones profundas en Bolivia y Latinoamérica. 203

De esta manera, el mandatario boliviano no solo reiteraba la ya señalada similitud

203 Discurso pronunciado por Evo Morales en La Paz, 16 de julio de 2009. Disponible en: http:// www.cubadebate.cu/especiales/2009/07/16/declaraciones-del-presidente-de-bolivia-evo-morales-en-losactos-por-la-celebracion-del-bicentenario-del-grito-libertario-video/\#.XGGSXy3SFmB 
y continuidad entre las luchas indígenas, el movimiento independentista y la Revolución Democrática y Cultural, sino que también proponía -desde una concepción antiimperialista- la misma correspondencia entre la política exterior estadounidense durante el siglo XIX y la desplegada a principios del siglo XXI en la región, planteo que se fundamentaba en la intervención norteamericana en el golpe en Honduras y en los acusados intentos de desestabilización organizados por los prefectos opositores de la región conocida como "Media Luna".

Por otro lado y a diferencia de lo sucedido en El Villar, esta vez su discurso buscó exhibir un proyecto político más abarcativo, en el cual la centralidad otorgada a las Fuerzas Armadas, campesinos e indígenas se viera matizada gracias a la incorporación de otros actores como los trabajadores mineros y la clase media, denotando, así, cierto esfuerzo por articular un bloque nacional-popular.

De igual forma, la cita revela cómo el aniversario patrio era entendido por el presidente como un ámbito para la reflexión política colectiva y como un canal propicio para renovar una suerte de llamado de alerta respecto a los peligros de la dominación imperial, así como para extender en la población una particular pedagogía de la historia nacional y regional.

Con respecto a Ecuador, el -casi frustrado-204 desfile militar organizado por el gobierno de la Revolución Ciudadana para la "velada libertaria" del 9 de agosto de 2009 -en el que marcharon pelotones de las fuerzas terrestre, aérea y marítima, así como de las tropas especiales- también fue reflejo de aquella tendencia por recobrar el relato bolivariano de la "patria grande" para entrelazarlo a las exigencias y agendas de entonces. Allí, algunos militares -luego de exhibir su equipamiento, tanques de guerra y armas de combate- declararon que formaban parte de "un Ejército con capacidad disuasiva, altamente capacitados" que se había dedicado en "estos últimos años a mejorar la preparación de sus soldados". ${ }^{205}$

\footnotetext{
204 Es que justo al inicio de la marcha algunos contratiempos pusieron en duda, al menos por unos minutos, la continuidad del desfile militar. Lo que sucedió fue que tres paracaidistas saltaron desde más de 5000 pies de altura para entregar al presidente la bandera nacional, la de Quito y la del Comando Conjunto de las FFAA, cuando uno de ellos, al aterrizar, se vio accidentado, suspendiéndose por un momento la ceremonia para que éste fuera asistido por paramédicos y trasladado al hospital militar.

205 El Nuevo Diario, Nicaragua, 9 de agosto de 2009. Disponible en: http://www.elnuevodiario.com.ni/ internacionales/54293-ecuador-celebra-bicentenario-independencia-desfile/
} 
En este sentido, cabe recordar que la ampliación y modernización militar llevada a cabo por el Poder Ejecutivo ecuatoriano se encontró estrechamente relacionada a los episodios sucedidos en marzo de 2008 cuando fuerzas militares colombianas atacaron un campamento de las Fuerzas Armadas Revolucionarias de Colombia (FARC) situado en territorio ecuatoriano, tras lo cual el gobierno de la RC decidió cortar las relaciones diplomáticas con el país vecino (Otálvora, 2008). De este modo, es posible sostener que la marcha militar desplegada durante el bicentenario ecuatoriano constituyó una herramienta más para reafirmar, exteriorizar y escenificar la retórica soberanista de la $\mathrm{RC}$.

Siguiendo esta línea, tampoco resultaron sorprendentes las características que asumió el desfile militar proyectado en Buenos Aires para la "semana del bicentenario" de Mayo. Es que, además de representantes de los regimientos históricos (como Patricios o Granaderos) o del Colegio Militar, la Escuela Naval o las Escuelas de Suboficiales (estrechamente vinculados en su día, cabe recordar, a la represión de la última dictadura cívico-militar), se decidió que desfilaran también veteranos de la guerra de Malvinas - quienes desplegaron una gran bandera argentina con la inscripción "gloria a los 649 héroes de Malvinas"- y delegaciones militares de países como Brasil, Uruguay, Bolivia, Ecuador y Venezuela, denotando un intento por convertir a la tradicional puesta en escena castrense en otro simbolismo más dirigido a ratificar aquella voluntad por fortalecer la imagen de una Argentina y una América del Sur unidas, resistentes e independientes.

De todos modos y a diferencia de lo sucedido en los otros casos, la notoria ausencia de Fernández de Kirchner, es decir, la Comandante en Jefe de las Fuerzas Armadas - interpretada como un "desaire" a los militares que, según algunas opiniones, habría terminado por "deslucir" al acto en cuestión-206 también puso de relieve la particularidad del vínculo entre los gobiernos kirchneristas y la institución en cuestión, especialmente, las reticencias del primero en cuanto al rol y protagonismo que lo militar

\footnotetext{
206 Véase: El Mundo, 24 de mayo de 2010. Disponible en: https://www.elmundo.es/america/2010/05/22/ argentina/1274563767.html y la siguiente crónica efectuada por un espectador: http:// patrullerasargentinas.blogspot.com/2010/05/deslucido-desfile-militar-del.html
} 
-asociado al pasado dictatorial- debía mantener bajo su gestión de gobierno.207

Ahora bien, de entre todas las puestas en escena marciales desplegadas durante los aniversarios patrios, quizás las más altisonantes hayan sido las planificadas por el Poder Ejecutivo venezolano. Así, cabe reparar, por un lado, en la parada cívico-militar acontecida en Caracas el 19 de abril de 2010, en la cual Chávez aprovechó para remarcar:

Aquí estamos los hijos y las hijas de Bolívar, doscientos años después en esta Caracas (...) cuna revolucionaria desde siempre y para siempre (...) somos hoy ya, de nuevo, una sola cosa, civiles y militares unidos, el pueblo y su fuerza armada garantizando la independencia venezolana; más nunca Venezuela será colonia yanqui ni colonia de nadie; llegó la hora definitiva de nuestra verdadera independencia doscientos años después. Y no solo de la independencia de Venezuela, porque (...) no sería posible sin la independencia (...) de la América Latina y el Caribe. ${ }^{208}$

De esa manera, el entonces mandatario venezolano abría el desfile denominado "Independencia y Revolución", en el que estudiantes, deportistas y cheers leaders, grupos folklóricos, indígenas, mineros, trabajadores de la industria alimentaria y obreros de Petróleos de Venezuela marcharon durante casi cuatro horas junto a la Fuerza Armada Nacional Bolivariana y la Milicia Bolivariana. ${ }^{209}$

Si bien breve en su discurso inaugural, distintos mensajes presidenciales fueron parafraseados por los locutores de la ceremonia: "Hemos puesto en marcha una nueva doctrina militar: la guerra de todo un pueblo. Al imperialismo y al imperio no hay que subestimarlo, pero tampoco hay que temerle"; "Queremos que el gobierno imperialista termine de aceptar la realidad: Venezuela se liberó, se liberó para siempre. 19 de abril: independencia y revolución, año Bicentenario"; "Estamos construyendo el socialismo,

207 Para un análisis de la política de defensa de los gobiernos kirchneristas y los modos en que estos se vincularon con las FFAA, véanse: Diamint (2008) y Canelo (2013).

208 Discurso pronunciado por Hugo Chávez Frías en Caracas, 19 de abril de 2010. Disponible en: https:// www.youtube.com/watch?v=LQv8yHiP go

209 Evocando a las fuerzas milicianas del período independentista y apelando al principio de corresponsabilidad, cabe señalar la creación, en 2007 por medio de un decreto presidencial, de un cuerpo especial conformado por civiles - principalmente, campesinos, obreros y pueblos originarios- como complemento de la Fuerza Armada Nacional Bolivariana para la ejecución de la defensa integral de la Nación. 
poniendo al ser humano como prioridad". Mientras tanto, los batallones de soldados que pasaban frente a la tribuna presidencial exclamaban consignas como "Soy paracaidista, soy submarista, soy un socialista, antiimperialista" o "Patria socialista, viva Venezuela".210

A lo largo de esta puesta en escena, un lugar destacado le fue otorgado a los comandos operacionales de Rusia, Argelia, Bielorrusia, Libia, Argentina, Bolivia, Ecuador, Brasil, Uruguay, Cuba, Nicaragua e Islas Vírgenes, así como a la flota de la Aviación Militar Bolivariana -compuesta de aviones de entrenamiento y combate de fabricación rusa y china-, lo cual pareciera haber subrayado la intención del Poder Ejecutivo por posicionar a Venezuela como sujeto fuerte de la región asociado al conjunto de países latinoamericanos con los cuales mantenía cierta solidaridad ideológica y/o a aquellas naciones con las cuales poseía acuerdos comerciales petroleros.

A su vez, aquel despliegue escénico habría puesto de relieve el propósito de la Revolución Bolivariana por construir alianzas geopolíticas con potencias capitalistas alternativas - como China, Rusia y los países árabes- capaces de contribuir a una diversificación de las relaciones internacionales y a un ordenamiento global de carácter multipolar (González Urrutia, 2006; Blanco y Linares, 2008; Ellner, 2009; Linares, 2010). ${ }^{211}$

Un año después, el "espectacular" desfile cívico-militar del 5 de julio de 2011 según lo calificó la prensa presidencial-212, en el que participaron "más de 12 mil 400 personas entre civiles y militares, misiones sociales, organizaciones populares, representaciones indígenas y representantes de 21 países Latinoamericanos y del

210 El País, 20 de abril de 2010. Disponible en: https://elpais.com/internacional/2010/04/20/actualidad/ 1271714401 850215.html

211 El despliegue militar que tuvo lugar durante el festejo patrio condujo a que el gobierno de la RB fuera nuevamente denunciado por Estados Unidos y diferentes medios de comunicación masivos de emprender una carrera armamentista, denuncia que ha acompañado al mismo desde sus comienzos cuando se decidió el aumento del gasto militar y se emprendió la compra de armamentos a Ucrania, China, Brasil y principalmente, Rusia. No obstante ese incremento presupuestario, Venezuela permanecía por debajo de la media de América Latina y la adquisición de equipamiento militar -en su mayoría, fusiles- habría respondido a los objetivos de provocar a Estados Unidos, equipar las milicias en caso de que una intervención norteamericana tuviera lugar y fortalecer el apoyo interno de las FFAA (Bertonha, 2010).

212 Albaciudad.org, 5 de julio de 2011. Disponible en: http://albaciudad.org/2011/07/en-fotos-elespectacular-desfile-civico-militar-del-5-de-julio/ 
Caribe",213 fue nuevamente la ocasión elegida para exhibir la capacidad bélica de Venezuela, a juzgar por la presentación en sociedad del vehículo de combate de infantería BMP-3 y los tanques T-72 comprados a Rusia en mayo de aquel año.

No obstante ello, la atención durante esta jornada se posó, principalmente, sobre la figura de Chávez, quien -habiendo vuelto por sorpresa de La Habana, donde recibía tratamiento médico, con el objetivo de participar de los festejos bicentenarios- fue el encargado de inaugurar la parada militar por cadena nacional de radio y televisión desde el salón Simón Bolívar ubicado en el Palacio Miraflores.

Escoltado por los altos mandos de las FFAA y por una gran pintura de Bolívar colgada detrás de él, el entonces presidente dio la bienvenida, en primer lugar, a las numerosas autoridades de distintos países de América Latina presentes en el Paseo de Los Próceres -entre las cuales destacó a Evo Morales, Fernando Lugo y José Mujicapara luego dirigir un saludo "al heroico pueblo venezolano" y recordar que

doscientos años (...) después de haber perdido aquella independencia que tanto costó, Venezuela en estos últimos diez años, la patria de Bolívar (...) soldados y pueblo hemos recuperado la independencia (...). Para concluir (...) y permitirles que arranque el rayo cívico-militar (...) Hemos iniciado otra larga marcha (...) un nuevo tramo de la gran escalada hacia la cumbre de la patria plena, independiente plena, soberana plena, desarrollada plena, socialista plena, humanista plena. Los invito a que con el morral (...) del fuego patrio, con todo nuestro espíritu (...) en lo uno y en el todo, en lo individual y en lo colectivo, fortaleciendo la unidad nacional, diría Bolívar, el cuerpo nacional en un todo, el espíritu nacional en un todo, el alma nacional en un todo, venciendo los divisionismos, venciendo las conspiraciones (...) a quienes pretenden desde dentro y desde afuera debilitar y echar abajo a la patria y su independencia, derrotándolos en paz (...) los invito a que iniciemos esta nueva larga marcha hacia el 24 de junio de 2021 para que conmemoremos (...) el rayo de Carabobo, la independencia nacional, la consolidación plena de la patria nueva, de la patria bolivariana, de la patria socialista. Para allá vamos con la ayuda de dios, del cristo redentor, de los santos de la sabana, con la voluntad colectiva (...) con la unidad de nuestros soldados, de nuestro pueblo (...) con el amor de (...) de nuestra juventudes, de nuestros trabajadores, de nuestras mujeres, de nuestros pueblos aborígenes (...) nuestros gobiernos hermanos (...) ese es el inicio del retorno, no solo (...) de Chávez, es el 
retorno de la patria plena, de la independencia plena (...) el retorno del pueblo de Bolívar (...) viviremos y venceremos, el retorno para siempre. 214

Aunque extensa, cabe destacar la relevancia de esta cita en tanto habilita a reflexionar sobre algunos elementos que hicieron a la esencia del chavismo en el momento específico en que no solo buscaba "consolidar" su giro hacia el socialismo, sino también se empezaba a discutir - ante el estado de salud del presidente- su continuidad y el problema de la sucesión.

Antes que nada, es posible observar, nuevamente, cómo la independencia conquistada por Bolívar se habría perdido y solo habría comenzado a ser recobrada con la llegada del chavismo al poder, quien se asumió como continuación y superación de aquel pasado revolucionario. 215 Para ello, la formación y validación de una alianza entre el pueblo -joven, trabajador, femenino e indígena- y las Fuerzas Armadas continuaba siendo imprescindible, lo cual explica, a su vez, la centralidad que el Poder Ejecutivo venezolano solía otorgar en sus prácticas conmemorativas a los desfiles -o, en palabras Chávez, "rayos"- cívicos-militares.

Con todo, gracias al triunfo en el referéndum constitucional de 2009 y frente al arribo del bicentenario de la independencia, ${ }^{216}$ Chávez comenzaba a dar por finalizada la etapa de gobierno iniciada en el 2006 cuando fue anunciado el giro hacia el

\footnotetext{
214 Discurso pronunciado por Hugo Chávez Frías en Caracas, 5 de julio de 2011. Disponible en: http:// www.todochavezenlaweb.gob.ve/todochavez/619-intervencion-del-comandante-presidente-hugo-chavezdurante-desfile-civico-militar-en-conmemoracion-del-bicentenario-de-la-declaracion-de-laindependencia-y-dia-del-ejercito-nacional-bolivariano

${ }^{215}$ De hecho, Chávez había llegado a afirmar tras el triunfo de la enmienda constitucional que habilitaba la reelección indefinida: "como decía Bolívar, la historia es un inmenso vientre que contiene más esperanza que sucesos pasados y los acontecimientos futuros serán superiores a los pretéritos". Discurso pronunciado por Hugo Chávez Frías en Caracas, 15 de febrero de 2009. Disponible en: https:// www.youtube.com/watch?v=Eic6UgWlYyU
}

216 Conviene recordar que el proyecto de reforma constitucional presentado por el presidente y la Asamblea Nacional en el año 2007 -el cual pretendía, entre otros puntos, convertir a Venezuela en un Estado socialista y aprobar la reelección presidencial indefinida, así como una Ley Habilitante que permitiera al presidente gobernar por decreto- había tenido como propósito radicalizar la RB aunque, al mismo tiempo, había terminado por profundizar el descontento en sectores opositores y aliados políticos por considerarla un agravio a la Constitución y/o a la democracia participativa. Finalmente, el rechazo de los electores en el referéndum constitucional marcó, así, la primera derrota política del chavismo, dando lugar a un proceso de mayor apertura política y autocríticas por parte del presidente (López Maya, 2008). Empero, el triunfo del oficialismo en las elecciones regionales de noviembre de 2008 reavivó aquel objetivo de aumentar el número de reelecciones no solo presidenciales, sino de todos los cargos de elección popular. El referéndum realizado el 15 de febrero de 2009 constituyó un verdadero punto de inflexión en tanto aprobó -no sin polémicas- la enmienda de la Constitución dirigida a incorporar las propuestas del entonces mandatario. 
socialismo y, en cambio, proclamaba, según sus palabras, el inicio de un "nuevo tramo", otra "larga marcha" cuyo destino final sería el 2021, esto es, el bicentenario de la batalla de Carabobo.

En este sentido, cuando Chávez anunciaba en el 2011, durante la inauguración de la parada militar del bicentenario, el inicio del retorno no solo se refería a la superación de su enfermedad y su permanencia física en el territorio nacional, sino también -y en estrecha relación- a la restitución de una nación "plenamente" independiente y socialista, para lo cual emprender una "larga marcha" hacia los doscientos años de Carabobo -es decir, otros diez años de Chávez en el poder posibilitados gracias al triunfo del 2009- resultaba fundamental.

En suma, los tradicionales desfiles militares se vieron resignificados, durante los festejos del bicentenario, en función de ciertas búsquedas, necesidades y/o fluctuaciones políticas que atravesaban cada uno de los Poderes Ejecutivos en cuestión. Así, aquellas puestas en escena pudieron servir como instancias propicias para ostentar la renovada capacidad militar de estos gobiernos o las nuevas alianzas geopolíticas tejidas por ellos, como excusas para discurrir sobre la situación interna y el rumbo a seguir de las naciones y/o como puntapiés para un alegato por una política exterior autónoma en función de los intereses nacionales y regionales.

\section{Cumbres, reuniones y ágapes}

En esta misma dirección fue que se inscribieron un conjunto de reuniones y encuentros protocolares organizados especialmente para la ocasión, como por ejemplo, la II Cumbre de la UNASUR desarrollada en la mañana del 10 de agosto de 2009 en Quito en la Sala Capitular de la Iglesia de San Agustín, donde se declaró la independencia en 1809 y donde los españoles firmaron la capitulación final en 1824. Tras recibir de manos de la entonces mandataria chilena, Michelle Bachelet, la presidencia pro tempore de la UNASUR, Correa explicó al auditorio allí presente cuáles eran los auténticos orígenes de la mencionada entidad:

No es posible recordar a la Junta Soberana de Quito sin recordar enseguida la gran epopeya cumplida por los pueblos de la América Nuestra nueva y milenaria, 
mestiza y morena, bajo la guía insustituible de Bolívar, San Martín y O'Higgins: Carabobo, Boyacá, Pichincha, Junín, Ayacucho y Maipú, son los nombres que nos ennoblecen la voz al pronunciarlos, y están para siempre ligados a esa llama inicial encendida el Diez de Agosto de 1809.

Es esa historia gloriosa, queridos amigos, compartida y solidaria de nuestros pueblos la robusta raíz que hoy sostiene y alimenta a esta Unión de Naciones, Unasur. (...)

La Unasur, materializa nuestra convicción de que la integración y la unidad suramericanas son imprescindibles para el desarrollo sostenible y el bienestar de nuestros pueblos, así como para contribuir a resolver (...) la pobreza, la inequidad y la exclusión. (...) la Unasur constituye una opción política capaz de (...) converger hacia un nivel superior de integración suramericana, esa integración siempre soñada por el Libertador Simón Bolívar. (...)

Pero tanto o más importante (...) es la urgente reacción que debemos consensuar para impedir que esos rancios grupos sociales acostumbrados a gobernar a espaldas del pueblo, pretendan retroceder las manecillas del reloj para reconquistar por la fuerza lo que no pudieron mantener por virtud del ejercicio de la democracia.217

Ahora bien, pese a las intenciones de Correa por exaltar el vínculo de unión "bolivariana" que encarnaba la UNASUR y, en especial, eludir cualquier mención al conflicto con Colombia desatado en el 2008, la ceremonia se habría visto caracterizada por cierto clima de "tensión y división". 218 Es que la ruptura de relaciones diplomáticas ocurrida entre los dos países vecinos en 2008, sumado a las críticas dirigidas al gobierno de Colombia por el acuerdo que estaba a punto de firmar con Washington, condujeron al entonces presidente de esta última, Álvaro Uribe, a ausentarse de la mencionada reunión y a que afloraran algunas diferencias entre los países miembros respecto a cómo abordar la mencionada problemática.

Mientras que la mandataria argentina abogaba por una resolución "racional" y diplomática en territorio neutral que incluyera al Jefe de Estado colombiano, al tiempo que sugería la importancia de hacer a un lado las "adjetivaciones y estridencias" o los

\footnotetext{
${ }^{217}$ Discurso pronunciado por Rafael Correa en Quito, 10 de agosto de 2009. Disponible en: https:// www.presidencia.gob.ec/wp-content/uploads/downloads/2012/10/10-08-09-Traspaso-Presidencia-Protempore-UNASUR.pdf

218 BBC Mundo, 10 de agosto de 2009. Disponible en: https://www.bbc.com/mundo/america latina/ 2009/08/090810_cumbre unasur_jp
} 
“discursos flamígeros", 219 otros países como Venezuela o Bolivia acusaron abiertamente a Uribe de "traidor", reclamando que fuera sancionado. ${ }^{220}$

En efecto, fue el titular del Poder Ejecutivo venezolano quien alertó, luego de aseverar que la decisión de Uribe de no viajar a Quito se debía a que éste había tenido "miedo a dar la cara (...) ante la traición”,221 que Venezuela se sentía "amenazada", que el gobierno colombiano defendía "la tesis del ataque preventivo", encontrándose la República Bolivariana en "la lista" y que "vientos de guerra" estaban comenzando a soplar en la región. 222

Finalizada la agitada cumbre de la UNASUR, todos los presidentes se trasladaron a la Asamblea Nacional para asistir al otro acto protocolar pautado para la jornada patria ecuatoriana, la segunda toma presidencial de Correa. En esta ocasión y a diferencia de lo ocurrido horas antes, el presidente sí haría referencia al conflicto que entonces mantenía en vilo a algunos gobernantes de la región:

El quinto eje de acción de nuestra revolución fue el rescate de la dignidad, soberanía y búsqueda de la integración latinoamericana. En este sentido, la Revolución Ciudadana seguirá trabajando en el fortalecimiento del multilateralismo y los espacios de integración latinoamericanos, especialmente con los países hermanos de UNASUR y del ALBA. (...)

Hoy, al celebrar el Bicentenario de la Primera Independencia, apostamos una vez más por esa huella bolivariana, que se ha traducido en la irrestricta defensa de nuestra soberanía, como lo demostramos en la invasión y bombardeo criminal de Angostura (...)

Hoy, sin embargo, estamos asistiendo a la configuración de otro escenario, una vez que el Gobierno de Colombia ha anunciado que se encuentra negociando la entrega, no ya de una, sino de siete bases para la operación del ejército de los Estados Unidos.

Ojalá la instalación de bases militares en territorio colombiano, no proponga

\footnotetext{
219 Discurso pronunciado por Cristina Fernández de Kirchner en Quito, 10 de agosto de 2009. Disponible en: https://www.cfkargentina.com/cfk-en-la-cumbre-de-unasur-2009/

220 BBC Mundo, 10 de agosto de 2009. Disponible en: https://www.bbc.com/mundo/america latina/ 2009/08/090810 cumbre unasur_jp

${ }^{221}$ Ibídem.

222 Discurso pronunciado por Hugo Chávez Frías en Quito, 10 de agosto de 2009. Disponible en: https:// www.youtube.com/watch?v=i198EAVHs4Q
} 
fortalecer la política guerrerista del Gobierno de nuestro vecino, y combatir, no al narcotráfico, sino a los gobiernos insurgentes de nuestra América. (...)

La instalación de bases (...) es un hecho que afecta a todo el Continente.

Por eso, conscientes de nuestra responsabilidad por el mantenimiento de la paz, y ratificando nuestra decisión de no involucrarnos en el interminable conflicto interno de Colombia, levantamos claramente nuestra voz de protesta por esta situación. Los hombres libres de América Latina, venceremos a los agenciosos recaderos del imperialismo. (...) Lamentablemente la amoralidad de los poderes mundiales no buscan la verdad, sino tan solo juegos de geopolítica donde a los obsecuentes tratan de convertirlos en héroes y a los que rechazamos el vasallaje tratan de convertirnos en villanos. Les aseguro que si aceptara bases militares en el país o involucrarnos en el Plan Colombia, mañana mismo pasaría de ser el amigo de las FARC a ser un estadista y demócrata insigne. Pero aquello nunca va a pasar. Prefiero el riesgo de ser libre a la nefasta solvencia del servil.223

De esta forma, Correa condenaba el comportamiento del gobierno colombiano, así como la injerencia de Estados Unidos en la región, lo cual no solo le permitía afianzar y legitimar la retórica integracionista y antiimperialista, sino sobre todo afirmarse él mismo y la RC en tanto expresiones genuinas de valores como la libertad, la honestidad y la paz. "Con revoluciones auténticas, con el despertar de nuestros pueblos, los próceres recuperan el don de la palabra, recobran el mando, la calidad fecunda de capitanes libertarios", ${ }^{224}$ había afirmado el mandatario, sugiriéndose a sí mismo como el nuevo intérprete y guía de la causa libertaria.

Varios meses después, durante el aniversario venezolano del 19 de abril de 2010, preocupaciones y argumentos similares volverían a aflorar en la sesión solemne organizada por el Poder Ejecutivo en la Asamblea Nacional, cuya invitada a pronunciar el discurso de orden había sido la entonces mandataria argentina, Fernández de Kirchner.

Con vistas a exhortar y postular una América del Sur integrada, democrática y soberana, a la vez que provocar -retórica y simbólicamente- a los poderes económicos y militares hegemónicos, Fernández de Kirchner había observado: "Este bicentenario

\footnotetext{
${ }^{223}$ Discurso pronunciado por Rafael Correa en Quito, 10 de agosto de 2009. Disponible en: https:// www.voltairenet.org/article161992.html

224 Ibídem.
} 
encuentra a los pueblos de América del Sur en una nueva etapa de transformación y en lo que yo denomino una Segunda Independencia"; para luego señalar, frente a un auditorio conformado por funcionarios oficialistas y jefes de Estado de las naciones del ALBA, que "es necesario ante un mundo que se ha vuelto a derrumbar en valores como el libre comercio (...) crear la unidad de nuestra región” y “ejercer el multilateralismo en serio y en todos los frentes". 225

La ya mencionada crisis diplomática que enfrentó a Colombia con Ecuador y Venezuela -agravada luego de que la primera negociara con Washington la utilización de siete bases militares colombianas para hacer frente al narcotráfico en la región-, así como el conflicto por la soberanía de las Islas Malvinas -reactualizado en el 2010 después de que se volvieran públicas las perforaciones de gas y petróleo ordenadas por el gobierno británico en las islas- explicaban la insistencia de Fernández de Kirchner para que se terminara "el doble estándar internacional en materia de respeto a las normas vigentes" y por "defender aquí en la América del Sur el concepto de paz y respeto de la voluntad democrática de cada pueblo, expresada libremente". ${ }^{226}$

La cooperación Sur-Sur, el cuestionamiento a las asimetrías del orden internacional y las denuncias de las políticas intervencionistas de las potencias hegemónicas ocuparon, así, un lugar central en las reuniones acontecidas durante las conmemoraciones bicentenarias. En este sentido, no resulta sorprendente que Chávez subrayara en la IX Cumbre del ALBA -la cual, cabe recordar, funcionó como acto de cierre de los festejos patrios del 19 de abril de 2010- que "el AlBA, en verdad, es, es alternativa, por eso tenemos que cuidarla, fortalecerla, alimentarla y avanzar, avanzar, avanzar". 227

Siendo la consolidación definitiva de la independencia la meta final hacia la cual aquel organismo se proponía avanzar, lo que entonces hacía falta, según la declaración final firmada por los países miembros durante aquel aniversario patrio, era el triunfo del "Ayacucho del Siglo XXI":

\footnotetext{
225 Discurso pronunciado por Cristina Fernández de Kirchner en Caracas, 19 de abril 2010. Disponible en: https://www.youtube.com/watch?v=gSKDneXOjYY

226 Ibidem

227 Discurso pronunciado por Hugo Chávez Frías en Caracas, 19 de abril de 2010. Disponible en: https:// www.youtube.com/watch? $v=$ YD44naUHGHE
} 
Reeditando en cada espacio de la vida social la victoria popular de Ayacucho, llamada por El Libertador "Cumbre de la Gloria Americana”, el ALBA tendrá como guía fundamental que cada una de sus acciones contribuya a sellar el final definitivo del dominio colonial, consolidando la independencia y la soberanía. Pero el Ayacucho del Siglo XXI será la victoria del Socialismo, única garantía de auténtica independencia y soberanía con justicia para el pueblo.228

Más informal que las reuniones o cumbres hasta aquí examinadas, el almuerzo de "camaradería", organizado en el hotel Radisson de La Paz por el Poder Ejecutivo boliviano en ocasión del bicentenario de la Revolución del 16 de julio de 1809, también resultó un espacio propicio para dar cauce a preocupaciones, proclamas y discusiones de tinte latinoamericanista y antiimperialista. La crisis política desatada en Honduras en junio de 2009 -la cual derivó en un golpe de Estado y, seguidamente, en la destitución y exilio del entonces presidente Manuel Zelaya- había sido, según un periódico local, el “tema que dominó el encuentro tanto que Chávez trajo en su avión a la depuesta canciller de Honduras, Patricia Rodas". 229

De este modo, el reducido grupo de mandatarios latinoamericanos allí presentes a saber, Morales, Chávez, Lugo, Correa y el entonces vicepresidente cubano, Jorge Luis Sierra- discutieron sobre la situación del país centroamericano, condenaron la participación de Estados Unidos e instaron a que el Jefe de Estado hondureño fuera restituido, lo cual condujo a la oposición boliviana a criticar el festejo y tildarlo "del 'inicio de campaña' de Morales ya que los discursos se centraron en la destitución del presidente hondureño y no en el motivo de la celebración". 230

Sin embargo, lo que más revuelo despertó fue la actuación de Chávez, quien

\footnotetext{
228 Manifiesto Bicentenario de Caracas. Declaración Final de la IX Cumbre del ALBA. Disponible en: http://sedici.unlp.edu.ar/bitstream/handle/10915/48876/ Manifiesto Bicentenario de Caracas abril $2010 \quad 6$ p. . pdf? sequence $=3$

Cabe recordar que dicha declaración fue firmada por los gobiernos de Antigua y Barbuda, Bolivia, Cuba, Dominica, Ecuador, Nicaragua, San Vicente y las Granadinas y Venezuela.

229 El Día, 17 de julio de 2009. Disponible en: https://www.eldia.com.bo/index.php? cat $=1 \& p l a=3 \&$ id articulo $=10343$
}

230 Agencia de noticias Ser, 17 de julio de 2009. Disponible en: https://cadenaser.com/ser/2009/07/17/ internacional/1247791519850215.html 
“convirtió [el] almuerzo en una fiesta de karaoke".231 Es que, en plena interpretación de la Orquesta Sinfónica Nacional que había empezado a ejecutar la popular canción venezolana "Alma llanera", el mandatario se apoderó de un micrófono y comenzó a entonar la letra de la canción, sumándose posteriormente su homólogo ecuatoriano. Finalizada la pieza, este último preguntó bromeando: “¿dónde está el tenor para que se lo lleve también a la Escala de Milán, por favor, al comandante Chávez?", 232 a lo cual el primero, entre risas y aplausos, retrucó: "Ahora que cante Correa", mientras éste continuaba: "ya le quitó el empleo al tenor de la Escala (sic) de Milán" y Chávez le devolvía: "no seas tímido".233

Minutos después, Correa volvía a tomar la palabra, esta vez, para hacer un pedido especial al director de orquesta: "después, maestro, una saya boliviana, okey, de esas para bailar, que acá el vicepresidente de la República [por García Linera] tiene ganas de bailar, me estaba diciendo (...) con cierta mesa que anda por ahí’. Tras las risas, el presidente ecuatoriano continuó molestando: "Póngalos a cantar a los cancilleres, que son más aburridos estos". ${ }^{234}$

De modo que, durante el encuentro desarrollado en La Paz, la contundencia y solemnidad de las proclamas político-ideológicas convivió con cierto espíritu lúdico y trivial, dando cuenta una vez más que "categorías como frivolidad y compromiso no siempre han aparecido, en la realidad histórica, con la carga de necesaria contraposición que usualmente se les asigna" (Bisso, 2009: 10).

Durante el bicentenario de la Revolución de Mayo, el Poder Ejecutivo argentino también decidió ofrecer un banquete aunque con características marcadamente diferentes al brindado por el de su país vecino. En este caso, se planificó para el cierre de la "semana del bicentenario" una cena de gala en la Casa Rosada que -bajo el lema “200 años, 200 invitados”- incluyó, según su anfitriona, Fernández de Kirchner, "muy simbólicamente a hombres y mujeres" que contemplaban "a todo el espectro de la

\footnotetext{
231 El Día, 17 de julio de 2009. Disponible en: https://www.eldia.com.bo/index.php? cat $=1 \& p l a=3 \&$ id articulo $=10343$

232 Registro audiovisual de la reunión. Disponible en: https://www.youtube.com/watch?v=POVkRpdS$\underline{\mathrm{JM}}$

233 Ibídem.

234 Ibídem.
} 
patria”. 235

Protocolar y sin adentrarse en temáticas de política interna o externa, la mandataria pronunció un breve discurso en el que se limitó a exaltar el espíritu de los festejos oficiales que ahora llegaban a su fin:

Yo creo que lo que hoy hemos logrado es darle reconocimiento a millones y millones de argentinos anónimos que participaron democráticamente en las calles como debía realmente celebrarse un Bicentenario: en democracia, con amplitud, con generosidad, con pluralidad, con diversidad y la verdad es que vale la pena $(\ldots)$

Hoy aquí los políticos somos absoluta minoría (...) y, la verdad, estoy muy contenta porque quiere decir que hay una muy buena representación de la sociedad argentina aquí esta noche. 236

La ceremonia, que contó con la presencia mayoritaria de "dirigentes empresariales, dirigentes gremiales, escritores, intelectuales, académicos, deportistas, artistas, cantantes, pintores, científicos, representantes de las distintas iglesias", ${ }^{237}$ así como de algunos presidentes de la región, ${ }^{238}$ figuras de la oposición, legisladores oficialistas y colaboradores cercanos a la mandataria, despertó, no obstante, algunas polémicas vinculadas, principalmente, al hecho de que ningún ex mandatario -salvo Néstor Kirchner- ni el entonces vicepresidente argentino, Julio Cobos, habían sido invitados a la misma.

\footnotetext{
235 Discurso pronunciado por Cristina Fernández de Kirchner en Buenos Aires, 25 de mayo de 2010. Disponible en: https://www.taringa.net/+progresismopj/cristina-fernandez-de-kirchner-discursos-delbicentenario lie 72

Cabe señalar que para la ocasión se decidió que cada mesa llevara, en lo que puede ser interpretado como otro gesto simbólico de integracionismo, nombres de batallas e insurrecciones clave relativas al proceso de independencia de América Latina. Así, se eligieron los siguientes acontecimientos: la insurrección de Tupac Amaru II, el cerco a La Paz, la Inconfidencia Mineira, las Invasiones Inglesas, el grito de Dolores, la batalla de Suipacha, la batalla de las Piedras, la batalla de Tucumán, la batalla de San Lorenzo, la batalla de Salta, la batalla de Chacabuco, la batalla de Maipú, la batalla de Boyacá, la batalla de Carabobo, la batalla de Pichincha, la batalla de Junín, la batalla de Ayacucho, la insurrección de los Treinta y tres orientales, la batalla de la Vuelta de Obligado, la batalla de San Javier, la batalla de San Jacinto, la batalla de Puebla y la batalla de Vertierres.

236 Ibídem.

${ }^{237}$ Ibídem.

238 Del conjunto de mandatarios que asistieron a las celebraciones del bicentenario argentino, solo se quedaron a la cena de gala ofrecida por el Poder Ejecutivo argentino, Chávez y Zelaya.
} 
Al ser consultado por la ausencia de este último en la cena de gala, el jefe de Gabinete, Aníbal Fernández, alegó: “hoy (...) ‘se hace complicado’ convocar al vicepresidente (...) al (...) no saber 'exactamente en condición de qué habría que invitarlo'. Cuando se le indicó que Cobos era el Vicepresidente de la Nación, Fernández retrucó: 'Función que él no cumple"”,239 en alusión al papel que éste había desempeñado durante la llamada "crisis del campo" en el otoño de 2008. ${ }^{240}$

\section{Inauguraciones}

Junto a los desfiles militares y los encuentros o convites a puertas cerradas, algunas agendas conmemorativas involucraron, asimismo, inauguraciones de edificios, salas o monumentos nacionales. ${ }^{241}$ En Venezuela, por ejemplo, Chávez había solicitado a la oficina presidencial de Planes y Proyectos la construcción de un nuevo monumento para el bicentenario de la Revolución del 19 de abril. El resultado fue el ya aludido "Monumento al 19 de abril", una columna metálica de 48 metros de altura de color rojo y negro situada en la plaza El Venezolano, la cual había sido calificada -por sus virtudes estético-revolucionarias-242 como un "cohete ideológico".243

Si bien los monumentos nacionales han, históricamente, buscado simbolizar el espíritu nacional o materializar los ideales o valores que supuestamente encarna la nación (Mosse, 2007), en este caso la pieza arquitectónica de estilo contemporáneo y policromía anarquista no pareció convencer a cierto sector de la ciudadanía particularmente preocupado por la "integridad" cultural del centro histórico de Caracas

\footnotetext{
${ }^{239}$ La política online, 21 de mayo de 2010. Disponible en: https://www.lapoliticaonline.com/nota/ nota-65683/

240 Recordemos que el mencionado conflicto se zanjó, finalmente, en julio de 2008 en el Senado con el
voto decisivo del entonces vicepresidente radical, quien se pronunció en contra de dicha medida.
}

241 Conviene recordar que en los cuatro países se destinaron también recursos para la renovación de plazas, avenidas, puentes y otros espacios públicos de las ciudades capitales con motivo de los bicentenarios.

242 Respecto al análisis del significado de la misma, véase capítulo II, páginas 39-40.

243 Fragmento de conversación entre Hugo Chávez y Francisco Sesto, 18 de abril de 2010. Video disponible en: https://www.aporrea.org/actualidad/n155496.html o transcripción disponible en: http:// www.todochavez.gob.ve/todochavez/637-intervencion-del-comandante-presidente-hugo-chavez-duranteprograma-especial-con-motivo-de-la-celebracion-del-bicentenario-del-inicio-de-la-gesta-independentistade-venezuela-el-19-de-abril-de-1810 
-en donde se encuentran las construcciones coloniales más importantes de la ciudad-, así como por la ausencia de un debate público sobre las características que un nuevo monumento histórico debía tener y el lugar donde debía ser emplazado.

En este sentido, al tiempo que la obra era caracterizada por sus artífices como "una proyección hacia el infinito, una llama, un faro, un norte, un lugar que marcará el sitio de la casa natal del Libertador", ${ }^{244}$ otras opiniones menos favorables la consideraban más bien un "tubo gigante", un "mamotreto", la "pinga de dios" o una "bayoneta portátil".245

Meses después, en Argentina, Fernández de Kirchner también inauguraba, además de la "Galería de los Patriotas Latinoamericanos", el Centro Cultural del Bicentenario en el ex palacio de Correo y Telecomunicaciones. La idea, según la presidenta, era "dotar a Buenos Aires, a la capital de todos los argentinos (...) de un gran centro cultural" que detentara un "aspecto federal, un aspecto popular, integrado a la sociedad (...) [y con] un fuerte componente también latinoamericano". 246

Bajo estas premisas, se montó para su apertura una exposición de arte con pinturas enviadas por cada una de las provincias del país y se recrearon -por medio de un sistema de computación de luces--, sobre la imponente cúpula transparente del renovado edificio, la bandera nacional, así como las de los países latinoamericanos. De igual modo, se exhibió una colección de filatelia, ocasión aprovechada por Fernández de Kirchner para alegar que Argentina había sido el primer país del mundo "que tuvo la idea de imprimir un sello postal con efectos conmemorativos". 247

A continuación, la mandataria también aprovechó la inauguración del tradicional edificio porteño para advertir:

Y miren, si algo tengo, es la defensa y el cuidado de nuestra identidad y patrimonio histórico porque yo siento muchas veces que nos han robado la historia, que nos la

\footnotetext{
${ }^{244}$ Así lo describió unos de los arquitectos encargados de su diseño y ejecución, Lucas Pou. Disponible en: https://www.aporrea.org/actualidad/n155496.html
}

245 Véase: http://lavainacultural.blogspot.com/2010/08/que-vaina-es-esta.html

246 Discurso pronunciado por Cristina Fernández de Kirchner en Buenos Aires, 24 de mayo de 2010. Disponible en: https://www.youtube.com/watch?v=SCOMgdgUF3Y 
han falsificado o que ni siquiera la sabemos porque no la han contado y yo creo que una de las cosas más importantes que tenemos que tener en este bicentenario es conocer nuestra propia historia, enterita, enterita, con los hombres y las mujeres anónimos y no tan anónimos que trabajaron para construirla. 248

Así, el evento devino una ocasión propicia para también exaltar, según se desprende de la cita anterior, la contribución que Fernández de Kirchner y, en especial, las puestas en escena planificadas para el bicentenario de Mayo, estaban haciendo a la preservación de la identidad nacional y al logro de un conocimiento "entero" de la historia argentina.

\section{Distinciones, ofrendas y rituales formales}

Diferentes tipos de distinciones, ofrendas y rituales de carácter formal también se hicieron presentes en las celebraciones bicentenarias. Respecto a las primeras, cabe recordar que, durante el festejo organizado en El Villar, el Poder Ejecutivo boliviano había presentado las monedas conmemorativas del bicentenario, una serie de piezas de oro grabadas con las figuras de Evo Morales a un lado y de Julián Apaza (Tupac Katari) y Bartolina Sisa en el reverso rodeadas, a su vez, de la inscripción "Bolivia para Todos: Complementariedad, Consenso, Equilibrio, Identidad".249

Dirigidas a distinguir a los diez campesinos agraviados un año antes en Sucre que “en su afán de apoyar a su líder tuvieron que pasar por momentos de humillación y discriminación”,250 la entrega de las monedas del bicentenario fue caracterizada por las autoridades como una "lucha de reconocimiento" en torno a estos "nuevos héroes" y -si volvemos sobre las imágenes en ellas impresas- al Estado Plurinacional y las rebeliones indígenas.

\footnotetext{
248 Ibídem.

249 Además de haber sido considerado un "autohomenaje", el hecho de que hayan sido grabadas en la Casa de la Moneda de Chile también fue reprochado por parte de la oposición política. En efecto, la prefecta de Chuquisaca afirmó indignada: "No podemos tolerar que en esas monedas de oro esté la figura de Evo Morales, y que esas monedas hayan sido acuñadas en Chile y no en la Casa de la Moneda de Potosí". El Mundo, 21 de mayo de 2009 (subrayado en el original). Disponible en: https:// www.elmundo.es/elmundo/2009/05/21/internacional/1242935913.html
}

250 Fragmento de la alocución oficial de la ceremonia conmemorativa para la televisión boliviana.

Disponible en: https:/www.youtube.com/watch?v=n6arSuzaVn0 
Es que, como recuerda Andrés Bisso, "a pesar de que las agendas de efemérides estructuran el ritmo de las celebraciones oficiales (...), las formas y los discursos que se aplican sobre ellas están sujetas a la improvisación y usos más variados por parte de los encargados de organizar dichos eventos" (2011: 39). De allí que fuera posible valerse de la celebración del bicentenario de la Revolución de Chuquisaca y las monedas conmemorativas para realzar las rebeliones indígenas y presentarlas como los fundamentos de la RDC.

En esta línea, lo que sucedió posteriormente en El Villar no fue otra cosa que reflejo de esos márgenes de acción inherentes a las prácticas festivas por los cuales se cuelan la apropiación y recreación. Distinguido el grupo de campesinos, llegó el turno de otro homenaje, esta vez, dirigido al Jefe de Estado boliviano, quien -luego de recibir una chaqueta militar similar a las que usaban los próceres de la independencia- fue proclamado "Libertador de los pueblos". 251

Asimismo, casi dos meses después, en los festejos bicentenarios de la Primera Junta Tuitiva de Gobierno desplegados en La Paz, nuevas distinciones serían otorgadas, esta vez, a los mandatarios invitados al "almuerzo de camaradería", quienes fueron condecorados con la medalla "Tupac Katari” por "su contribución a la profundización de la cooperación y solidaridad entre los Estados, Naciones y Pueblos indígena originario campesinos de Latinoamérica y el mundo, sobre principios de una relación justa, equitativa y con reconocimiento de las asimetrías". ${ }^{252}$

Tanto en la capital boliviana como en Quito y Caracas las agendas conmemorativas comprendieron, asimismo, ofrendas florales a los "héroes" de la independencia. Sin embargo, fue en la última ciudad donde este hecho adquirió mayor trascendencia en la medida que fue el acto elegido por el Poder Ejecutivo venezolano para dar inicio a la jornada conmemorativa del 19 de abril.

\footnotetext{
251 Como cabía esperar, este episodio agudizó la crítica de la oposición: "El prefecto de Tarija, Mario Cossío, cuestionó: 'parecería que ahora hay autonombramientos de libertadores (...) Eso es un exceso político que no tiene límites' (...) el ex presidente Jorge Quiroga lamentó que Morales haya 'insistido en distorsionar y manipular la historia, dividir y dañar a los bolivianos, ofender y dañar a Sucre, y en manchar la patria"”. Disponible en: http://www.diariocritico.com/noticia/152010/noticias/bicentenario-enactos-paralelos.html
}

252 Decreto supremo Nº206 del 15 Julio 2009. Disponible en: http://www.derechoteca.com/ gacetabolivia/decreto-supremo-0206-del-15-julio-2009/ 
En cuanto tal, el solemne homenaje a Bolívar en el Panteón Nacional contó con la presencia de mandatarios de varios países de América Latina y el Caribe, así como de Chávez, quien -al tomar la palabra para darles la bienvenida y agradecer su presenciadeclaró:

Hemos querido venir a tributar aquí a las cenizas del padre Simón Bolívar nuestro fervor, nuestro amor, nuestro compromiso de unidad y liberación. 200 años hacen hoy exactamente de aquel día en que se inició el proceso de liberación, el proceso de independencia de nuestros pueblos. Caracas desde siempre fue una cuna y fue una llama que luego contribuyó a encender toda la pradera (...)

19 de abril, bienvenido, 200 años de batalla. Hoy estamos aquí, siguiendo el mandato de los padres y madres de la patria. Con la conciencia, hoy más despierta que nunca, de que solo unidos y unidas como hoy, lo estamos logrando una vez más, después de 200 años de batalla, solo unidos y unidas tendremos la patria grande. ${ }^{253}$

Descontando el hecho de que la formación y consolidación del liderazgo político del "padre" Simón Bolívar fue posterior a los sucesos de 1810, su homenaje aquella mañana de abril no solo posibilitó a Chávez insistir sobre la importancia de una unión continental, sino especialmente trazar un paralelismo entre la época de las guerras de independencia cuando tuvo lugar en Caracas una jornada cívico-militar que intentó derrocar al gobierno español -movimiento que a la postre sería encabezado por aquel héroe defensor de "la unidad y liberación" de todo el subcontinente- y la aparición a fines de siglo XX, nuevamente en la capital venezolana, de otra figura militar que, apelando al pueblo, sería la primera en comprometerse a culminar aquella misma empresa y, como consecuencia, en volver a "encender toda la pradera".

Por último, los actos conmemorativos del bicentenario reprodujeron una serie de rituales formales de carácter cívico - reiterados año a año- como, por ejemplo, la apertura del arca que contiene el Acta de la Independencia durante el aniversario del 5 de julio en Caracas o el encendido de la "Tea de la Libertad" en la casa de Murillo -con el posterior desfile de antorchas- en ocasión de la conmemoración de la Primera Junta

\footnotetext{
253 Discurso pronunciado por Hugo Chávez en Caracas, 19 de abril de 2010. Disponible en: https:// www.aporrea.org/actualidad/n155529.html
} 


\section{Tuitiva de Gobierno de La Paz.254}

Lo mismo sucedió con las expresiones rituales de tipo religioso, es decir, con "los tradicionales y solemnes tedéums, ceremonias que más allá de la repetición de un rito ancestral cuya forma está pautada, muestran particularidades según el contexto (nacional) de ejecución y cambios en relación con los momentos y periodos históricos" (Amati, 2013: 45).

En efecto, el Poder Ejecutivo boliviano decidió que la jornada del 16 de julio comenzara en la mañana con una novedosa ceremonia ecuménica o interreligiosa oficiada en la Catedral Metropolitana Nuestra Señora de La Paz, la cual contó con la participación del presidente y de representantes de las Iglesias católica, evangélica, bahai, judía e islámica, así como de los pueblos indígenas. A fin de subrayar y explicitar el espíritu de comunión que se le había querido imprimir al oficio, el sacerdote jesuita y antropólogo Xavier Albó -responsable de conducir la misma y de efectuar un cambio al "Padre nuestro" al pronunciar "Padre nuestro y Madre nuestra que estás en los cielos"concluyó que la misma fue "un paso más que dan los bolivianos en busca de su reconocimiento como nación plurinacional en la que todos son iguales". ${ }^{255}$

Ahora bien, finalizada la ceremonia, tuvo lugar la tradicional procesión de la Virgen del Carmen -declarada patrona de Bolivia en 1855 y Generala y Patrona de las Fuerzas Armadas de la nación en 1948- durante la cual "los fieles criticaron la ausencia del Gabinete Ministerial, considerando que podría ser parte de la ignorancia que se quiere olvidar de la fe católica, además que es un comunista que entrega el país a un Gobierno venezolano". ${ }^{256}$

En este sentido, cabe recordar que Morales no solo se había ausentado de la procesión para asistir al almuerzo de "camaradería", sino que ese mismo día, en el marco de la "parada militar bolivariana de los pueblos", había declarado que

\footnotetext{
254 Según reza el mito, el héroe criollo habría prendido la antorcha antes de subir a la horca en enero de 1810 cuando fue ejecutado por las autoridades peninsulares. De ahí que se trate de la "Tea de la Libertad".

255 Los Tiempos, 16 de julio de 2009. Disponible en: http://www.lostiempos.com/actualidad/nacional/ 20090716/celebracion-inter-religiosa-inicia-actos-protocolares-del-bicentenario y
}

256 Politica y Desarrollo, 23 de julio de 2009. Disponible en: http://politicaydesarrolloarchivo.blogspot.com/2009/07/los-nuevos-ataques-de-evo-la-iglesia.html 
algunos jerarcas de la Iglesia Católica en Latinoamérica usaron la oración como una anestesia que hace dormir al pueblo para someterlo a su dominación (...)

Saben hermanas y hermanos, no son toda la Iglesia Católica, padres y hermanas me ayudan a resolver problemas de educación y salud, pero algunos jerarcas son el instrumento de dominación de los pueblos para que no se liberen. Cuando el pueblo rompe los instrumentos de dominación ahí vienen las dictaduras militares. Cuando no pueden dominarnos con los instrumentos de dominación, viene la oración y cuando no pueden dominarnos con la oración, viene el fusil.257

De este modo, el conflicto que mantenía el mandatario boliviano con ciertos sectores de la Iglesia católica -el cual surgió tempranamente cuando el primero comenzó a abogar para que Bolivia pasara a ser un Estado aconfesional, suprimiendo el carácter oficial de la religión católica fuertemente asociado, en el imaginario del MAS, al colonialismo español- también se hacía presente en la celebración bicentenaria.

Casi un año después, el aniversario de la Revolución de Mayo devino, asimismo, escenario de los desencuentros entre el Poder Ejecutivo argentino y la Iglesia católica debido al anuncio de Fernández de Kirchner de que el tedéum -históricamente realizado en la Catedral Metropolitana de Buenos Aires- se celebraría en la Basílica de Nuestra Señora de Luján, Patrona de la Argentina. ${ }^{258}$ Al respecto, un editorial explicaba:

A contramano de la historia y la tradición, el matrimonio presidencial mudó en forma sistemática el Tedéum desde que llegó al poder. Desde el Gobierno se argumentó que el objetivo era "federalizarla", aunque existe la sospecha de que la

\footnotetext{
257 Discurso pronunciado por Evo Morales en La Paz, 16 de julio de 2009. Disponible en: http:// www.cubadebate.cu/especiales/2009/07/16/declaraciones-del-presidente-de-bolivia-evo-morales-en-losactos-por-la-celebracion-del-bicentenario-del-grito-libertario-video/\#.XGQJ_C3SFmC
}

258 La elección de la Basílica de Luján habría tenido que ver con el hecho de que se trataba, según Fernández de Kirchner, de un lugar "con un fuerte simbolismo (...) donde cientos de miles todos los años salen de la puerta de su casa y llega aquí peregrinando". Aunque también se habría visto relacionada con "una anécdota ocurrida en la quinta de Olivos (...) Contó que cuando comentaba el tema del Tedeum con su madre y su hermana, en un momento 'apareció el que ya saben, que es mi compañero de hace 35 años -dijo por Kirchner-, y se incorporó a la charla'. Y él dice, 'pero a vos te parece en la Basílica de Luján, no sería mejor en la Catedral, son los 200 años'... 'pero ahí está la patrona de los argentinos', contó que acotó Cristina.' $Y$ justo -siguió- (Kirchner) se sienta en el respaldo de un sillón donde suele sentarse siempre y no le pasa nada. Y dijo: 'Bueno, la patrona, la patrona' y cuando dijo eso, el sillón se le dio vuelta y casi se cae, y mi hermana inmediatamente le dijo: 'La Virgen, señal de que tiene que ser la Basílica de Luján'." Clarín, 31 de marzo de 2010. Disponible en: https://www.clarin.com/edicionesanteriores/cristina-anuncio-tedeum-bicentenario-lujan_0 Bkp3CUATYx.html 
intención era evitar una posible homilía crítica de Bergoglio. ${ }^{259}$

Empero, la retirada del tedéum hacia distintos lugares del interior -puesta en marcha desde el 2005 bajo la presidencia de Néstor Kirchner (con la excepción del oficio religioso del 2006 realizado en Buenos Aires) y justificada bajo la bandera del federalismo- también fue interpretada como un "activo trabajo de prescindencia de las jerarquías y de proximidad con grupos católicos y movimientos cristianos que se opusieron a la dictadura y a la etapa neoliberal 'rechazando el autoritarismo identitario de la mayoría del episcopado"” (Mallimaci en Amati, 2013: 62).

En todo caso, lo cierto es que, frente a aquella decisión, el entonces cardenal y arzobispo de la capital, Jorge Bergoglio, resolvió efectuar en el mencionado templo porteño otra ceremonia de acción de gracias no oficial y paralela a la estipulada por el Poder Ejecutivo nacional -a la que terminarían asistiendo varios referentes de la oposición como, por ejemplo, el otrora jefe de Gobierno de la ciudad de Buenos Aires, Mauricio Macri, así como el presidente de la Sociedad Rural Argentina, Hugo L. Biolcati-,260 todo lo cual no hizo más que fomentar la polémica que rodeó a la celebración bicentenaria argentina. ${ }^{261}$

En Venezuela, con motivo del bicentenario de la firma del Acta de la Declaración de Independencia, también tuvo lugar una resonante ceremonia religiosa en la Academia Militar de la Guardia Nacional, la cual -además de ser transmitida por la principal televisora del Estado- contó con la participación de Chávez, sus ministros y la cúpula militar. Es que, además de dar gracias por el bicentenario de la independencia, la misa interpretada como una suerte de tregua entre el Poder Ejecutivo venezolano y la Iglesia católica 262 estuvo dirigida a pedir por la salud del presidente de la República, quien,

${ }^{259} \mathrm{La} \mathrm{Voz}, 20$ de abril de 2010. Disponible en: https://www.lavoz.com.ar/content/bergoglio-reivindico-sucatedral-para-el-tedeum-del-bicentenario

\footnotetext{
260 Para un análisis sobre la homilía de Bergoglio en la Catedral de Buenos Aires, véase: Amati (2013).

${ }^{261}$ El escenario en cuestión habría desatado una cadena anónima de correos electrónicos que instaba a que "El tedéum de Bergoglio en la Catedral" fuera "más grande que la manifestación del campo" y "que la Catedral” eclipsara "a Luján (la Virgen nos comprenderá)... La república está en peligro", justificaban los escritos. La Nación, 18 de mayo de 2010. Disponible en: https://www.lanacion.com.ar/1265982preocupa-a-la-iglesia-la-politizacion-del-tedeum
}

262 El imparcial, 13 de julio de 2011. Disponible en: https://www.elimparcial.es/noticia/87742/america/laiglesia-perdona-a-chavez-y-le-da-la-uncion-de-los-enfermos.html 
además, recibió la unción de los enfermos.

Con el propósito de evitar especulaciones o sobresaltos, el sacerdote encargado de oficiar el rito, monseñor Mario Moronta, insistió: "Es la unción de los enfermos, antes se llamaba la extremaunción (...) no hay que asustarse, esto es para que el enfermo tenga fortaleza física, pero sobre todo espiritual (...)".263 Con mayor vehemencia, el propio mandatario iría más lejos y aseguraría, una vez finalizado el rito, “que en Venezuela la única transición que hay es del capitalismo al socialismo, al salir al paso de voces que", envalentonadas por ese escenario, habían comenzado a clamar "por una transición en el país".264

De modo que los doscientos años de las "independencias" fueron, indudablemente, vistos como la oportunidad para escenificar y dramatizar el nuevo rumbo que, en aquel entonces, se esperaba que transitaran estos países de la región, lo cual demandó que las liturgias políticas se vieran readaptadas de acuerdo a los propósitos y expectativas de cada Poder Ejecutivo.

En consecuencia, es posible adelantar que, más allá de que el tipo de ritos y actos protocolares del bicentenario no hubiera experimentado demasiadas variaciones ofrendas, distinciones, desfiles militares, inauguraciones, reuniones, ágapes, rituales cívicos y/o religiosos estructuraron, al igual que antaño, las propuestas conmemorativas oficiales-, fueron las nuevas trazas que estos asumieron lo que posibilita echar luz sobre las búsquedas y los estilos políticos de los gobiernos en cuestión y, en última instancia, el clima de época que entonces parecía envolver, al menos en parte, a la escena sudamericana. Volveremos sobre este punto en el capítulo final.

\section{Las aristas "populares" de los festejos bicentenarios}

\footnotetext{
${ }^{263}$ La Voz, 13 de julio de 2011. Disponible en: https://www.lavoz.com.ar/noticias/mundo/chavez-recibiouncion-enfermos

264 El imparcial, 13 de julio de 2011. Resaltado en el original. Disponible en: https://www.elimparcial.es/ noticia/87742/america/la-iglesia-perdona-a-chavez-y-le-da-la-uncion-de-los-enfermos.html
} 
Si uno de los objetivos -según las normativas o declaraciones oficiales relativas a los bicentenarios- había sido proyectar festejos con una fuerte impronta "popular",265 la ortodoxia oficial inherente a las celebraciones patrias debió, entonces, verse atenuada y acompañada de una serie de puestas en escena que -dirigidas a interpelar directamente al pueblo- o bien se nutrieron de imaginarios, tradiciones y/o prácticas populares, o bien tuvieron a aquél como su protagonista indiscutido.266 De este modo, ferias, recitales, juegos, proyecciones, muestras y exposiciones, así como desfiles y rituales informales y populares completaron las agendas conmemorativas del bicentenario.

\title{
Ritual indígena
}

Respecto a estos últimos, el Poder Ejecutivo ecuatoriano fue el único que, además de prescindir de la realización de un tedéum oficial, otorgó un carácter central, dentro del programa oficial de los festejos bicentenarios, a un ritual indígena. Es que la decisión de iniciar la "velada libertaria" el 9 de agosto de 2009 hizo que ésta coincidiera con el día internacional de los pueblos indígenas. De ahí que el primer acto de la jornada patria fuera una toma de posesión simbólica del mando presidencial a través de un ritual de purificación ejecutado por los representantes de los Taitas (padres) y Mamas de la comuna de Chimba, ubicada 70 kilómetros al norte de Quito:

\begin{abstract}
A las cinco de la mañana, se inicia la elaboración del camino sagrado que lleva a la purificación espiritual. Los yachaks colocan en el piso hierbas medicinales como ruda, yerbaluisa, manzanilla, arrayán, para que se limpie de las malas energías.
\end{abstract}

\footnotetext{
265 A estas alturas, resulta obvio afirmar que "lo popular" constituye, dentro las ciencias sociales y humanas, un objeto elusivo y controvertido. Sin intenciones de ahondar en los debates que al respecto se han suscitado, se sugiere consultar, no obstante, Hall (1984), García Canclini (1987; 1988), Sarlo (1988) y Chartier (1994).
}

266 En virtud de este criterio, acaso se vuelve discutible la decisión de ubicar los desfiles cívico-militares en el apartado sobre actos y ritos protocolares, en la medida que aquellos no solo involucraron al pueblo en tanto espectador, sino que -como sucedió en Bolivia y Venezuela- los mismos contaron con la participación activa de, por lo menos, algunos sectores de la ciudadanía. Sin embargo, el peso del protocolo, de los rigurosos órdenes y jerarquías internos, así como de la idea de corporación y solemnidad inherentes a este tipo de actos rituales (DaMatta, 2002) constituye el motivo por el cual aquellos fueron clasificados de esa manera. 
Mientras tanto, Franklin Columba, presidente de la Asociación de Taitas y Mama Yachacks, coloca con sus manos los granos de la última cosecha, que simboliza volver a sembrar la tierra para que tenga mejores días y sus frutos sean prósperos para su pueblo. El trigo, sinónimo de unidad y continuidad; el maíz, la fuerza que necesitará el líder para librar altercados; y la cebada, el vigor que debe demostrar un mandatario.

En tanto, Mercedes Pallo, junto a 50 mujeres de la Asociación Tránsito Amaguaña colocan más leña al fuego para que el choclo, las papas y habas estén bien cocidas, porque es el alimento de ofrenda al Primer Mandatario.

Son las 8:30, la banda de pueblo anuncia la llegada de los representantes de las comunidades con la tradicional wipala (bandera indígena) quienes con gritos de: "pueblo unido por la vida" y "viva Correa" reiteran su apoyo a la gestión gubernamental del Jefe de Estado. ${ }^{267}$

Frente a las comunidades indígenas del sector y aquellas aglutinadas en la Federación Nacional de Campesinos, Indígenas y Negros (FENOCIN), ${ }^{268}$ Correa recibió un poncho de color rojo en alusión a la tierra del país, un collar de flores dirigido a simbolizar la diversidad, una medalla con el escudo de la cruz de los pueblos indígenas y un bastón de mando que significaba la transmisión de los conocimientos de la tierra y los antepasados.

De igual modo, el acto -que también había involucrado la apertura de un Centro Cultural Comunitario en honor a la líder indígena oriunda de esa localidad, Tránsito Amaguaña- contó con la presencia de Evo Morales y Rigoberta Menchú, quienes recibieron, asimismo, las bendiciones del ritual y la medalla "Bicentenario" como símbolo de libertad de las comunidades.

Haciendo quizás alusión al entonces creciente distanciamiento entre el Poder Ejecutivo ecuatoriano y ciertos sectores indígenas del país, Franklin Columba, el taita yachak (padre sacerdote) responsable de oficiar la ceremonia, expresó:

\footnotetext{
${ }^{267}$ Desde abajo, 10 de agosto de 2009. Disponible en: https://www.desdeabajo.info/mundo/item/13401correa-recibió-bastón-de-mando.html

268 Cabe señalar que, a diferencia de lo sucedido en la otra investidura simbólica efectuada en el poblado de Zumbahua en el 2007, los grupos indígenas organizados en la Confederación de Nacionalidades Indígenas del Ecuador (CONAIE) y la confederación Kichwa del Ecuador (Ecuarunari) se ausentaron de la ceremonia en cuestión debido a la cada vez más tensa relación entre el gobierno de la RC y las mencionadas organizaciones sociales tras la aprobación de la Constitución en octubre de 2008 y, especialmente, luego de que el gobierno autorizara la extracción minera a gran escala. Sobre este asunto, véase: Ramírez Gallegos, 2010; Lalander y Ospina Peralta, 2012.
} 
Ponemos toda la madera para que puedan gobernar de la mejor manera al pueblo, para que sean humildes, no estirados, humildes como nuestros abuelos (...) queremos estar unidos como el saco del maíz, cuidémoslo para que no se rompa, para que no se desgrane y estemos todos unidos y no otros por aquí y otros por allá, eso se los encomiendo a ustedes hermanos, para que no permitan la desunión de nuestros pueblos, para que dirijan con amor, porque en el amor hacia el pueblo es que está el progreso. ${ }^{269}$

Ahora bien, concluida la ceremonia y las danzas tradicionales, también Correa se pronunció ante el público allí presente para destacar:

No somos excluyentes, no discriminamos, sabemos que somos el Gobierno de todas y todos los ecuatorianos, pero sabemos que también debemos tener opciones preferenciales. Preferencias por aquellos que siempre han sido postergados, los pobres, nuestros pueblos indígenas (...)

Esta revolución bolivariana y alfarista al servicio de los más débiles no tiene regreso (...) para radicalizar esta revolución auténtica y soberana no vamos a utilizar balas ni piedras ni botas. Vamos a utilizar lápices, escuelas, caminos, dignidad, pasión por la patria, pensamientos lúcidos, canciones porque será también la revolución de la alegría".270

Sin referir a los desencuentros políticos y programáticos que entonces eclipsaban la relación entre el Poder Ejecutivo y distintos movimientos sociales -incluidos vastos sectores indígenas-, Correa aprovechaba la ocasión para anunciar la radicalización de la RC y presentarla como un proceso pacífico e incluyente, "de todas y todos los ecuatorianos", cuya prioridad, eran, no obstante, los desposeídos, estableciendo, de ese modo, una filiación y una afinidad electiva entre su gobierno y el pueblo.

Desfiles

\footnotetext{
${ }^{269}$ Palabras pronunciadas por el líder indígena encargado de conducir el ritual en Cayambe, 9 de agosto de 2009. Disponible en: https://www.aporrea.org/internacionales/n140208.html

270 Discurso de Rafael Correa pronunciado en Cayambe, 9 de agosto de 2009. Disponible en: http:// www.cubadebate.cu/noticias/2009/08/09/correa-toma-posesion-del-cargo-de-presidente-bajo-ritualindigena/\#.XGq0sS3SFmB
} 
Es así que tanto la ceremonia indígena como el discurso presidencial que tuvieron lugar la mañana del 9 de agosto en Quito pretendieron nutrir la dimensión popular que se le quería conferir al festejo patrio. Y, para avanzar en esta dirección, el Poder Ejecutivo ecuatoriano organizó, asimismo, el llamado "Desfile de la Ecuatorianidad", en el cual se exhibieron 24 carros alegóricos, cuyo propósito era destacar el patrimonio de cada una de las provincias del país. ${ }^{271}$ Algunos relatos de aquella jornada describían:

Los espectadores que desde muy temprano en la mañana se ubicaban a lo largo de la avenida de los Shyris pudieron apreciar a al carro alegórico que representaba a Galápagos que destacaba su flora y su fauna, únicas en el mundo. Las provincias del Oriente resaltaron el verde de la selva y sus etnias ancestrales. Pichincha destacó la gesta libertaria de los próceres. El Austro hizo alusión a sus culturas ancestrales y a su bella arquitectura. Santa Elena nuevamente mostró la belleza de sus playas. ${ }^{272}$

"El chulla quiteño", "Ambato tierra de flores"... fueron algunas de las canciones que se escucharon durante los primeros 40 minutos del desfile. En la mayoría de carros alegóricos se montaron un par de manos abiertas como símbolo de la productividad. Pero el verde del banano, el rojo de las flores y el amarillo del maíz en las alegorías de El Oro, Tungurahua y Chimborazo, respectivamente, también se encargaron de reflejar la tierra fértil de Ecuador y, más aún, cuando se combinó con el café de la madera de Imbabura, la nieve del Cotopaxi y las aves multicolores de Napo y Pastaza. (...)

Al son de la marimba se presentó ante el público la alegoría de Esmeraldas, en la cual mujeres y hombres vestidos de blanco y verde contoneaban sus caderas en el baile típico de la provincia. Un poco más pausadas pero igual de tradicionales se exhibieron las danzas de Zamora Chinchipe, Los Ríos y Bolívar. La religiosidad se caracterizó en el carro de Loja, donde en medio de la comparsa de saraguros y de las llamas se erigía la imagen de la Virgen de El Cisne. En cambio, en el montaje de Imbabura, el dios de los incas, el Sol, resplandecía bajo la luz del intenso astro quiteño. ${ }^{273}$

\footnotetext{
${ }^{271}$ Cabe advertir que, debido a la ausencia de registros audiovisuales del desfile, solo será posible recuperar algunos fragmentos del mismo.

${ }^{272}$ Ecuadorinmediatio.com, 9 de agosto de 2009. Disponible en: http://www.ecuadorinmediato.com/ index.php? module $=$ Noticias $\&$ func $=$ news user view $\&$ id $=110302$
}

${ }^{273}$ La Hora, 10 de agosto de 2009. Disponible en: https://lahora.com.ec/noticia/916022/color-y-civismopor-el-bicentenario- 
De modo que las celebraciones bicentenarias también estuvieron orientadas a recobrar y explotar los imaginarios populares, para lo cual los desfiles se convirtieron en herramientas decisivas. Esto fue especialmente evidente en el caso de Argentina, donde el Poder Ejecutivo planificó y otorgó un lugar central a una serie de paradas que, con mayor o menor protagonismo, se propusieron reconstruir y exhibir la historia e identidad nacional en clave carnavalesca, popular y federal.

La primera de ellas fue el "Desfile Federal", el cual -desarrollado en la tarde del 22 de mayo- estuvo dirigido -al igual que el de Ecuador- a representar las culturas y tradiciones de cada una de las provincias del país. Representaciones de Jujuy con un rebaño de llamas, Neuquén con dinosaurios y trabajadores del gas y petróleo, La Rioja con divinidades diaguitas o Córdoba con grupos de cuartetos fueron algunas de las postales que se observaron durante la parada. 274

Al día siguiente, el espectáculo central fue el "Desfile de la Integración", en donde marcharon -frente al entonces canciller Jorge Taiana y embajadores de varios países- más de ochenta colectividades nacionales establecidas en el país. "Con caporales, con kimonos, con tiroleses, con túnicas blancas, con armaduras, con tambores", narraba una crónica del desfile, "4 mil representantes de las naciones que conviven en la Argentina (...) les dieron un día más de color a los festejos de los 200 años de la Revolución de Mayo". ${ }^{275}$

De este modo, el gobierno nacional reforzaba, a la vez que reactualizaba, el mito de una Argentina construida a través de la inmigración, con la diferencia de que ahora las comunidades extranjeras ya no eran solamente europeas ni las diferencias étnicas incompatibles con las políticas de Estado, sino que ellas -con su diversidad culturaltambién hacían a los rasgos de la nación del bicentenario.

Finalmente, tuvo lugar el "Desfile de los 200 años", el cual constituyó uno de los actos principales de la jornada patria propiamente dicha. Realizado el 25 de mayo, el mismo -que contó con la presencia de la mandataria argentina y estuvo protagonizado

\footnotetext{
274 Véase Página 12, 16 de mayo de 2010. Disponible en: https://www.pagina12.com.ar/diario/sociedad/ 3-145766-2010-05-16.html y Derf. Agencia Federal de Noticias, 23 de mayo de 2010. Disponible en: https://www.derf.com.ar/las-provincias-el-festejo-del-bicentenario23-mayo-2010-telam-n341100
}

275 Página 12, 24 de mayo de 2010. Disponible en: https://www.pagina12.com.ar/diario/elpais/ 1-146261-2010-05-24.html. También, Página 12, 23 de mayo de 2010. Disponible en: https:// www.pagina12.com.ar/diario/ultimas/20-146231-2010-05-23.html 
por el grupo de teatro de vanguardia Fuerza Bruta- consistió en una procesión de carrozas "temáticas" que, orientadas a representar la esencia de la nación argentina, recorrieron el microcentro de la capital. 276

Tras una primera carroza dirigida a evocar a los pueblos originarios, llegaba el turno de simbolizar a "La Argentina" mediante una joven de rasgos mestizos vestida de celeste y blanco, colgada de una grúa sobrevolando al público mientras la escoltaban, por debajo de ella, gauchos, paisanos, negros y patricios, así como un grupo de jóvenes interpretando música folclórica del noroeste argentino.

Luego de los dos cuadros sobre la independencia -analizados en el capítulo II- y de la carroza dirigida a representar el combate de La Vuelta de Obligado, los acontecimientos históricos cedieron paso, momentáneamente, al folclore y al campo evocados con artistas disfrazados con trajes típicos, bailando y tocando ritmos nativos como la zamba, el chamamé, el malambo y la chacarera al tiempo que una cosechadora lanzaba trigo al cielo y un grupo de "gauchos" -figura clásica y obligatoria del imaginario nacional que, no obstante el agudo conflicto del 2008, fue reivindicada por el gobierno tal como ha venido sucediendo desde principios de siglo $\mathrm{XX} \_277$ tocaba la guitarra y preparaba un asado.

Esta versión arquetípica de la argentinidad fue asociada a otro de los hitos usualmente considerado como "constitutivo" de ésta, justamente la ola de inmigrantes iniciada a finales del siglo XIX. De esta manera, se construyó un gran barco a vapor de treinta metros de largo denominado "Doscientos", colmado de actores caracterizados como europeos y europeas de época.

Ahora bien, este relato canónico y armónico del ser nacional -condensado en sus raíces gauchescas y europeas- buscó ser aggiornado con la alusión a otro conjunto de inmigrantes, "los que no vinieron en barco", según relataba el historiador y divulgador Felipe Pigna, en referencia a las colectividades latinoamericanas y orientales más

\footnotetext{
276 Registros de este desfile se encuentran disponibles en: https://www.youtube.com/results? $\underline{\text { search query }=\text { desfile }++ \text { fuerza }+ \text { bruta }+ \text { bicentenario }}$

277 Para un análisis de la construcción mítica del gaucho y su incorporación al panteón simbólico de la nación a principios de siglo XX, véase Cattaruzza y Eujanian (2002), Fradkin (2003) y Garavaglia (2003). Respecto al uso de la figura del gaucho, las costumbres rurales y la tradición frente a las amenazas que la inmigración y sus “complots maximalistas” suponían a la identidad nacional, véase Casas (2016).
} 
recientes, las cuales buscaron ser integradas a la narrativa de la nación a través de un desfile típico de la comunidad boliviana y taiwanesa.

La escena destinada a simbolizar los "movimientos políticos y sociales" que marcaron la vida política del país durante la primera mitad del siglo XX resulta, asimismo, interesante en tanto consistió en una gran marcha aunada de manifestantes comunistas, socialistas, anarquistas, radicales y peronistas donde cánticos como "anarquía, anarquía" o "huelga general" convivían con pancartas con consignas como "voto libre", "ni dios, ni amo, ni marido" o "Perón cumple, Evita dignifica", mientras se repartían copias de los panfletos que el Partido Comunista solía repartir en sus campañas como el llamado a realizar un boicot en 1919 a la empresa Gath \& Chaves.

A la industria nacional también se le reservó una gran carroza -y un lugar en el rompecabezas de la nación- mediante la alusión a una fábrica de la popular firma SiamDi Tella, en donde los clásicos automóviles y heladeras giraban suspendidos en el aire mientras artistas de Fuerza Bruta hacían acrobacias alrededor de ellos.

Un brusco cambio de clima fue el encargado de avisar la llegada de una nueva temática: la democracia y los golpes de Estado. Sin alusiones explícitas y con un juego de luces y sonidos dirigidos a causar tensión, apareció en escena una imponente reproducción de la Constitución Nacional colgada desde lo alto y rodeada de urnas, la paloma de la paz, la balanza de la justicia y una figura de una persona con los brazos en alto rompiendo las cadenas. Al cabo de unos minutos y luego de un fuerte sonido de disparos, toda la estructura comenzaba a prenderse fuego figurando las interrupciones del orden constitucional argentino.

Seguidamente, uno de los últimos cuadros se centró en las Madres de Plaza de Mayo representadas por un conjunto de mujeres con pañuelos luminosos blancos sobre sus cabezas quienes, bajo la lluvia y en silencio, caminaban simulando la famosa ronda alrededor de la Pirámide de Mayo. En línea con las dos últimas puestas en escena, una marcha de soldados -algunos artistas, otros ex combatientes reales- con cruces blancas a sus espaldas anunciaba la Guerra de Malvinas. Un nuevo sonido de salvas los haría caer al suelo, fingiendo el impacto de las balas, al tiempo que las cruces que antes colgaban de sus espaldas, despuntaban elevadas en alusión a los caídos sepultados en el cementerio de Darwin. 
De repente, un nuevo giro interrumpía el tono dramático y tenso que había adquirido el desfile al aparecer en escena un conjunto de murgas como símbolo de un regreso - popular, carnavalesco y festivo- de la democracia. Esta escena, sin embargo, cedió rápidamente su lugar al cuadro de las “crisis económicas”, el cual consistió en un grupo de personas en movimiento vestidas con atuendos de diferentes épocas, peleándose y agarrándose desesperadas, en medio de un remolino de billetes hasta terminar todas ellas tiradas en el piso alrededor del dinero.

Hacia el final del espectáculo, llegaba el turno de homenajear a Latinoamérica con un desfile de grandes globos iluminados sobre los cuales se encontraban impresos los nombres y las banderas de todos los países de la región- y el momento de simbolizar a los tiempos "presente y futuro" - con una gran burbuja transparente dentro de la cual se hallaban estudiantes con guardapolvos y científicos investigando-- El punto de llegada de esta narración apuntó, nuevamente, al ideal latinoamericanista, así como al carácter estratégico para el futuro de la nación de estímulos y avances en materia educativa y científica, lo cual -aun sin ser explicitado- buscaba ser enlazado a las políticas del gobierno kirchnerista.

A fin de ahondar en la propuesta detrás del "Desfile de los 200 años", resultan particularmente esclarecedoras las palabras del creador de Fuerza Bruta, Diqui James, quien explicaba:

No intentamos hacer un relato de la historia de nuestro país, sino un gran espectáculo artístico en donde todos los argentinos se vean reflejados en algún momento del desfile. Queremos que se respire libertad, fiesta, poesía y el bullir de una gran celebración. La materia prima del Desfile es 'Lo que nos hace Argentinos', y el resultado es un hecho artístico libre de prejuicios, libre de toda confrontación, donde se festejarán nuestras diferencias. 278

De esta manera, la mirada del artista daba cuenta de una intención de generar condiciones propicias para que el espectáculo en cuestión funcionara como un atractivo colectivo más allá de los posicionamientos político-partidarios e ideológicos que, por aquel entonces, dividían a la ciudadanía. De lo que se trataba, entonces, con éste y con

278 Clarín, 25 de mayo de 2010. Disponible en: https://www.clarin.com/ediciones-anteriores/showvanguardia-hoy-termina-fiesta-bicentenario 0 _HJeDB8CpFg.html 
los otros desfiles desplegados durante el bicentenario de Mayo era de movilizar, articular y reconciliar múltiples identidades individuales y colectivas, presentándolas a todas ellas como la esencia fundante de la nación.

En Venezuela, más de 7.200 personas -entre las cuales se incluyeron actores, músicos, bailarines, acróbatas, cirqueros y técnicos- formaron parte del colorido desfile histórico denominado "Independencia para Siempre", el cual se había efectuado en el Paseo Los Próceres a modo de cierre del festejo patrio de julio de 2011.279 "Esta sí es nuestra verdadera Historia! No la que nos falsificó la burguesía apátrida! Qué despliegue de talento y de conciencia! Felicitaciones!",280 reaccionó -a través de su cuenta oficial de Twitter- el entonces mandatario venezolano, quien había tenido que ausentarse de casi todas las actividades conmemorativas por sus problemas de salud.

Luego de la entonación del himno, el inicio de la parada lo protagonizó -al igual que en el desfile argentino, aunque en orden invertido- una joven vestida con los colores de la bandera nacional que, colgada desde una grúa, bailaba y hacía acrobacias frente al público.

Tras ella, se representó la "cosmogonía indígena" a través del mito de Amalivaca, uno de los más importantes y populares de Venezuela, según el cual un cataclismo natural producido por un gran diluvio hizo desbordar el río Orinoco, devastando a la etnia tamanaco. "Entre las tierras y las aguas, surgió el héroe creador, Amalivaca (...) surcando aquel paisaje ahogado en la catástrofe", relataba una de las voces en off mientras avanzaban sobre la avenida una marioneta de 8 metros de altura de la mencionada figura mítica, así como de la anaconda Lalikilpará, de más de 50 metros, la cual -reza la leyenda- pese a haberse propuesto inundar la tierra para acabar con la humanidad, fue derrotada por el primero.

Seguidamente, apareció un nuevo escenario móvil que representaba una palmera llamada moriche, de cuyas semillas -asegura el mito Tamanaco- nacieron los hombres y las mujeres que, tras el diluvio, volvieron a poblar el planeta. Actores y bailarines

\footnotetext{
279 Registros de este desfile se encuentran disponibles en: https://www.youtube.com/watch? $\underline{\mathrm{v}=\mathrm{OOU} 2 \mathrm{~h} \_\mathrm{wxWE}}$
}

280 Twit de Hugo Chávez Frías, 30 de julio de 2011. Disponible en: http://www.psuv.org.ve/portada/ desfile-bicentenario-revivio-grandes-momentos-historia-venezuela-fotos/\#.XG6UVC3SFmA 
disfrazados de indígenas se ubicaron, así, bajo sus pies simulando "el nuevo pueblo" que habitaba la tierra.

El relato continuó con una carroza con forma de casco español, sobre la cual se posaron actores disfrazados de soldados y sacerdotes, así como de indígenas y esclavos africanos. Dirigida a evocar la llegada de "los invasores europeos" movidos por "el ansia de conquista, de enriquecimiento", narraban los relatores, ésta dio paso a un gran barco que simbolizaba el Leander, es decir, la famosa embarcación con la que Francisco de Miranda -personificado, a su vez, por un actor situado en la cofa de la misma flameando la bandera nacional- arribó a Venezuela en 1806.

Posteriormente, otro escenario móvil simuló un cabildo, en el que actores y actrices disfrazados de criollos, mestizos e indígenas representaron los hechos del 19 de abril de 1810 y del 5 de julio de 1811. Detrás de él, una gran estructura de metal sirvió de decorado para representar la Batalla de Carabobo, protagonizada por un hombre sobre un caballo blanco que caracterizaba a Bolívar. Luego de evocar el enfrentamiento entre los ejércitos realista y patriota, los actores y actrices que encarnaron al segundo se dispusieron a bailar y agitar pañuelos blancos al son de una batucada.

Los siguientes episodios históricos en ser recuperados fueron la Rebelión Popular de 1846 y la Guerra Federal iniciada en 1859, simbolizados mediante un ejército de campesinos que, al son del Himno de la Federación denominado "Oligarcas temblad" y liderados por un actor disfrazado de Ezequiel Zamora, circuló por la avenida del Paseo Los Próceres evocando su enfrentamiento en contra del "ejército oligárquico comandado por José Antonio Páez”, según indicaba una de las relatoras.

Estructuras metálicas que aparentaban ser equipos o maquinarias propios de la industria petrolera, junto con una marcha de trabajadores de la misma, evocaron, a continuación, la "era petrolera" y el "bloqueo imperialista" -lo cual fue retomado en el capítulo II-. La dictadura de Marcos Pérez Jiménez fue, asimismo, simbolizada a través de carrozas con pantallas gigantes que pasaban imágenes y audios de la época, mientras actores vestidos con ropa de los cincuenta bailaban al son de una salsa venezolana. Segundos después, mientras la voz en off señalaba que el gobierno se había convertido en una "dictadura militar prepotente", algunos actores suspendían el baile para, en cambio, simular que eran perseguidos y torturados por la llamada Seguridad Nacional. 
El breve festejo de los actores que buscaba reproducir lo sucedido el 23 de enero de 1958 -cuando Pérez Jiménez se exilió en República Dominicana tras el levantamiento de vastos sectores de la sociedad, así como de las Fuerzas Armadas- dio paso a la "era del puntofijismo". Respecto al modo en que el denominado Pacto de Puntofijo fue caracterizado durante el desfile, los relatores explicaban, mientras avanzaba una carroza que imitaba las Torres de El Silencio, ${ }^{281}$ que "los partidos de la burguesía (...) instauraron un estado sectario, excluyente y pseudodemocrático no menos represivo que la dictadura anterior y sometido al imperio estadounidense"; sumado al hecho de que "el puntofijismo desarrolló políticas populistas que obsequiaban a las masas las migajas de un festín de corrupción y entrega de la riqueza nacional a los capitales extranjeros".

Tras esa curiosa crítica anti-populista, imágenes de publicaciones periódicas con titulares como "Arde el país" y la fotografía de un joven militar con una bandera que decía "MBR 200" detrás de él eran proyectadas por pantallas gigantas colgadas de varios escenarios móviles con formas de televisión anunciando, por un lado, las fuertes protestas ocurridas en 1989 conocidas popularmente como "El Caracazo" y, por el otro, el intento de golpe de Estado encabezado por Chávez en 1992.

El símbolo elegido para caracterizar la etapa inaugurada en diciembre de 1998 fue una réplica del primer satélite venezolano, denominado Simón Bolívar y lanzado desde China en el 2008,282 el cual avanzó ante el público sobre una plataforma móvil, al tiempo que cientos de personas pertenecientes a diferentes misiones sociales marchaban armando sobre sus cabezas las imágenes de la bandera y la constitución nacionales. El desfile culminó, finalmente, con otra marcha militar - esta vez, de los regimientos históricos conducidos por un nuevo "Bolívar" a caballo-, un recital en vivo -donde alrededor de 300 parejas bailaron joropo con la música de Cristóbal Jiménez y Vidal Colmenares-y la proyección del videomapping.

De modo que el desfile histórico organizado por el Poder Ejecutivo venezolano habría estado dirigido a restaurar y celebrar la historia nacional, pero también a

\footnotetext{
281 Inauguradas en 1954, las mismas constituyeron durante décadas el ícono más representativo de la modernidad en Caracas.

282 Cabe señalar que este objeto también tendría un lugar protagónico en el videomapping proyectado sobre los Monolitos del Paseo Los Próceres una vez finalizado el desfile histórico.
} 
estimular la moral y la conciencia de sus espectadores. Es que el relato allí escenificado no solo pretendía entretener a los espectadores o narrar y visibilizar una versión alternativa a la fraudulenta historia de la "burguesía apátrida" que, por fin, hacía lugar a tradiciones, identidades y acontecimientos "verdaderamente" populares, sino que aquel "despliegue de talento y de conciencia" -como lo había calificado Chávez por Twitterhabría apuntado, en última instancia, a tener un efecto particularmente edificante sobre el pueblo venezolano allí presente.

En suma, todos estos desfiles del bicentenario tuvieron como propósito encumbrar y valorizar al pueblo y a la patria por medio de la escenificación y espectacularización de su cuerpo territorial -paisaje, geografía, naturaleza, recursos- y/o sus tradiciones culturales -danza, música, religión, mitología, arquitectura, historia-. Animar e interpelar al pueblo suponía, entonces, recuperar y teatralizar ciertos elementos de su entorno natural y/o cultural que, simultáneamente, contribuyeran a la restauración y delimitación de la naturaleza "auténtica" - a la vez, diversa y hermanada- de cada nación.

\section{Videomappings}

Enlazando arte con tecnología, los videomappings proyectados en Caracas y Buenos Aires también transitaron en esa dirección. A diferencia del caso venezolano donde la proyección funcionó como una suerte de síntesis del relato histórico desplegado durante el desfile "Independencia para Siempre", el videomapping exhibido sobre el Cabildo de la capital argentina tuvo como objetivo lo que el "Desfile de los 200 años" había buscado evitar, esto es, sistematizar y puntualizar los acontecimientos y procesos históricos de la historia argentina considerados fundamentales.

Más allá del carácter tradicional y didáctico de las narrativas históricas y los recursos estilísticos que acompañaron a estas puestas en escena, "la principal característica de este [tipo de] espectáculo", observa Pablo Ortemberg, es que "el mapping existe solamente en 'el vivo', en el espacio público, y está pensado para que sea apreciado por la multitud; las emociones que genera (...) son en gran parte fruto de la situación de grupo" (2013:173). 
De modo que la decisión de narrar las "historias patrias" a través de una técnica en ese entonces- sumamente innovadora capaz de espectacularizar y jugar con la memoria histórica no fue casual. Como ha observado el mencionado autor, el videomapping resultó ser un instrumento particularmente eficaz a la hora de cautivar a la ciudadanía, revalorizar el patrimonio tangible y propiciar cierto apoderamiento del espacio público:

Si por momentos podría pensarse este show como una frivolización estetizante que opera a partir de clisés, también puede concebirse como un auténtico bricoleur que activa zonas emotivas de la experiencia colectiva generando sentidos de comunidad y revitalizando con nuevos significados los monumentos, aunque más no sea durante 10 minutos (Ortemberg, 2013: 178).283

Sin embargo, se podría afirmar que atracciones de gran espectacularidad como los desfiles artísticos o videomappings no alcanzaban para convertir a los aniversarios patrios en verdaderas fiestas populares donde el público tuviera una participación activa. Si bien aquellos podían contribuir a despejar el culto nacional de la ortodoxia y solemnidad oficial, no es fortuito que desde antaño atraer el entusiasmo del pueblo supusiera la participación de éste en eventos más mundanos, dinámicos, directos y/o populares.

\footnotetext{
283 A este respecto, cabe mencionar, a modo de ejemplo de esa intención por proyectar un festejo patrio capaz de atraer a la ciudadanía en general sin importancia de las adscripciones políticas, la forma en que la conmovida década de los setenta fue representada en el videomapping argentino. Allí, la perspectiva de los derechos humanos y la memoria de la violencia política convivió con referencias ligadas al mundo del arte, el espectáculo, el deporte y la política, en general, dando lugar a una particular recreación del período al proponer una mirada menos coherente, rígida y solemne sobre los actores y las ideas que habrían singularizado a la nación durante aquellos tiempos.

Voces y retratos de personajes históricos sumamente diversos -como Alberto Olmedo, Agustín Tosco, Salvador Allende, Charly García, Perón abrazado a José I. Rucci, Sandro, Héctor J. Cámpora, Jorge L. Borges, Ringo Bonavena, Rodolfo Walsh, Nacha Guevara, Julio Cortázar, Guillermo Vilas y Mercedes Sosa- fueron utilizadas para representar los primeros años de la década hasta que un corte tajante anunció el golpe cívico-militar de 1976, caracterizado a través de audios e imágenes de la Junta Militar, militares armados y vehículos Ford Falcón, José A. Martínez de Hoz con un fondo de fábricas en crisis, figuras y sonidos que insinuaban torturas y desapariciones, audios y fotografías de la ronda de las Madres de Plaza de Mayo y referencias a la Guerra de Malvinas con alocuciones de Leopoldo Galtieri e imágenes del cementerio de Darwin.

De esta manera, los "setenta" habrían estado, ciertamente, marcados por el terrorismo de Estado, pero también por algunos íconos propios del patrimonio artístico, cultural, deportivo y musical de la Argentina, entre los cuales despuntaron figuras no necesariamente comprometidas ni compatibles con las causas políticas progresistas usualmente reivindicadas por los gobiernos kirchneristas aunque sí sumamente populares.
} 
Juegos, entrenamientos, recitales y marchas

En este sentido, era esperable que las propuestas conmemorativas del bicentenario incluyeran, asimismo, un abanico variado de actividades informales tal como sucedió, en el caso de Argentina, con los paseos gastronómicos con comidas típicas de diferentes países, pantallas gigantes para transmitir el último partido de la Selección nacional antes del Mundial, un desfile de autos y motos antiguas por la avenida 9 de Julio, un show con autos de Turismo Carretera o la "Feria de las Provincias", en la cual se reservó "un sitio especial para la denominada Provincia 25, compuesta por el millón y medio de argentinos radicados en el exterior y para la Provincia del Futuro", la cual habría apuntado a "la participación activa y la reflexión de los niños, a partir [de] propuestas lúdicas en torno a los valores de hombres y mujeres que forjaron la historia." 284 Sumado a todo ello, la instalación de diferentes "Postas temáticas" buscaron funcionar como "espacios de interacción con la gente dedicados a la discusión y reflexión"285 de temáticas relativas a Ciencia y Tecnología, Juventud y Educación, Medio Ambiente, Cultura, Derechos Humanos y Producción. ${ }^{286}$

Sin embargo, las puestas en escena que más entusiasmo habrían despertado fueron los innumerables espectáculos musicales desarrollados a lo largo de la "semana del bicentenario", los cuales congregaron a un heterogéneo arco de artistas nacionales y latinoamericanos. De hecho, un editorial de un periódico español, al hacer referencia a los recitales ofrecidos por "el cubano Pablo Milanés, el brasileño Gilberto Gil, los argentinos León Gieco y Víctor Heredia así como el elenco chileno de Los Jaivas", observaba que "sólo en los funerales de Evita Perón o en los de Carlos Gardel se vio una masa humana como la que llenó la avenida, en la noche del sábado".287

\footnotetext{
${ }^{284}$ La Nación, 27 de abril de 2010. Disponible en: https://www.lanacion.com.ar/1258615-desfiles-acielo-abierto-para-el-festejo-del-bicentenario

285 Ibídem.

286 A modo de ejemplo, en el stand del Ministerio de Ciencia y Tecnología se pusieron a disposición de la ciudadanía robots desarrollados en la Argentina y financiados por el Estado nacional, satélites para obtener información climática, medioambiental y oceánica, maquetas del Polo Científico Tecnológico y de la Central Atómica Atucha II, así como una exhibición del proceso de producción de combustible atómico.
}

287 El Mundo, 29 de junio de 2010. Disponible en: https://www.elmundo.es/america/2010/06/18/ argentina/1276872034.html 
Ahora bien, junto a estos artistas -cuyas propuestas musicales se han visto caracterizadas por su fuerte contenido y compromiso político y/o social-, se incluyeron, asimismo, otros cantautores como Abel Pintos y Soledad o grupos como "Onda Vaga" ubicados, más bien, del lado mainstream de la cultura musical argentina.

En Ecuador, el Poder Ejecutivo también planificó para su aniversario de la gesta emancipadora una serie de actividades lúdicas destinadas al consumo popular como, por ejemplo, la llamada "Pavimento de Color". Con ese propósito, niños de entre 5 y 13 años fueron convocados para que representaran, a través de la pintura sobre el asfalto de la avenida 6 de diciembre, la "diversidad cultural" del país. El polifacético evento contó, asimismo, con un espectáculo musical de la Banda Municipal y de danza del Ballet Folclórico Latinoamericano Kallpañan, así como con una exhibición de perros amaestrados de la Policía, finalizando con la entrega de los libros Aquí Ecuador de Claudio Mena Villamar y Panorama del Arte de Hernán Rodríguez Castelo.288

Carlos Yánez, Director de museos y uno de los organizadores de la actividad, explicaba la importancia que él otorgaba al acontecimiento en cuestión: "El objetivo de pintar sobre la calzada es que los niños hagan un enfrentamiento hacia el arte contemporáneo, ya que no necesita un soporte tradicional. Cuando pasen los carros se van a borrar las pinturas y esa es la idea". ${ }^{289}$ Por otro lado, testimonios de algunos de sus protagonistas permiten constatar, igualmente, cómo las prácticas festivas resultan experiencias raramente unívocas y cerradas en donde las dinámicas político-ideológicas pueden convivir, dar lugar e, incluso, verse eclipsadas por componentes o intereses ligados a la cultura popular y de masas:

Sentado en el piso y con gran concentración, Ulises Mena, de 13 años, pintó un cuadro al que tituló "Fuera chapetones". "Yo representé cuando los españoles salieron de América y dejamos de ser esclavos", dijo el chiquillo [...] La Virgen de El Panecillo, flores, animales, paisajes, edificios, personajes de dibujos animados, montañas y hasta escudos de equipos de fútbol fueron algunos de los dibujos.

\footnotetext{
${ }^{288}$ El primero de ellos consiste en una guía turística del Ecuador escrita en 1990 por un economista, escritor y profesor que forma parte del gobierno de la RC; el segundo, escrito por un ensayista, crítico de arte e historiador de la literatura, hace un recorrido desde el arte precolombino hasta el contemporáneo.

${ }^{289}$ La Hora, 9 de agosto de 2009. Disponible en: https://lahora.com.ec/noticia/915576/color-infantilsobre-la-6-de-diciembre-
} 
Michel Cadena, de 13 años [...] De forma minuciosa trazó la iglesia de San Blas.

"Escogí este tema porque se me hace fácil", indicó la niña (...)290

En efecto, cabe recordar que en cada una de las plazas de la capital donde se habían montado los escenarios dirigidos a ilustras aquellos episodios y actuaciones de personajes de la historia nacional considerados precursores de la RC, también se organizaron, a fin de complementar a esas puestas en escena, numerosas actividades culturales y artísticas de muy diverso signo, las cuales involucraron desde desfiles de "Grupos Ancestrales" y bandas populares, retretas de Bandas Institucionales, espectáculos de danzas nacionales y latinoamericanas, exhibiciones de ballet andino y clásico, pasando por clases de preparación de dulces tradicionales y festivales gastronómicos, orquestas, encuentros y obras de teatro infantiles, exposiciones de armamento y uniformes militares hasta proyecciones cinematográficas, 291 realizaciones de murales y grafitis, conciertos de rock y blues y, por último, la presentación de la orquesta sinfónica con un repertorio de música folklórica y popular ecuatoriana -con preeminencia de obras de Luis Humberto Salgado-.292

De todos modos, fue el acto de la tarde del 10 de agosto, denominado "El presidente con su pueblo", el que mayor poder de convocatoria tuvo. Es que más de cuarenta mil personas provenientes de distintos puntos del país llegaron al estadio olímpico Atahualpa en donde tendrían lugar variados espectáculos musicales, así como una tercera posesión simbólica de Correa, esta vez, acompañado de "su pueblo", su vicepresidente y sus homólogos Chávez, Zelaya y Raúl Castro.

Inaugurado con la banda ecuatoriana "Pueblo nuevo" que interpretó la canción chilena "El pueblo unido jamás será vencido" -una de las más reconocidas expresiones musicales de protesta inspirada en la frase del político colombiano Jorge Eliécer Gaitán Ayala y popularizada en el Chile de Allende meses antes del golpe militar-, el concierto continuó con el mandatario ecuatoriano cantando baladas románticas junto al popular

\footnotetext{
290 Ibídem.

${ }^{291}$ Se trató de la película "Mientras Llega el Día" la cual, dirigida por Camilo Luzuriaga y basada en una novela homónima de Juan Valdano, narra la historia de amor entre una joven quiteña y un bibliotecario que participa de los episodios ocurridos entre los agostos de 1809 y 1810 en Quito.

292 Compositor ecuatoriano de música clásica y popular, influenciado por ritmos tradicionales de la región.
} 
grupo de folclore argentino, "Los Nocheros", "despertando gritos de sus fanáticas para luego convertirse en el animador de la noche". 293

Después de su actuación musical, llegó el momento de la nueva toma del mando presidencial, para lo cual Correa -vestido con jeans, camisa del color de su partido y sombrero- invitó al escenario a los mandatarios latinoamericanos allí presentes junto a quienes, tomados de la mano, comenzaron a corear "Alerta, Alerta, Alerta que camina la espada de Bolívar por América Latina”. En un clima relajado como el del almuerzo de camaradería en La Paz, Correa le cedió el micrófono al "don Hugo", quien lo primero que hizo fue prometer que iba a hablar "muy poquito", lo cual despertó comentarios irónicos como el de Castro que advirtió al público que, entonces, sería mejor que se sentara.

Inmediatamente, una asambleísta de Alianza País pidió al mandatario venezolano que recitara una poesía, frente a lo cual Chávez preguntó su nombre y reflexionó: “yo ahora entiendo, con el perdón de los caballeros (...) por qué Bolívar llegó aquí y se amarró con la Manuela, y llegó Sucre y también, compadre. Menos mal que uno no se queda aquí dos días, sino que se va rápido. No te pongas celoso, Correa!". 294

Tras declamar el poema "Por aquí pasó" de Alberto Arvelo Torrealba y pronunciar unas breves palabras de agradecimiento y ánimo hacia el pueblo ecuatoriano, el entonces presidente venezolano cedió el micrófono al resto de los mandatarios -quienes reiteraron las críticas a Estados Unidos y Colombia-, incluido un enfático Correa que aprovechó la ocasión para señalar:

tenemos un inmenso capital político pero que no se traduce en estructuras organizadas y movilizadas así que somos vulnerables. Podemos ser fácil presa de grupos pequeñitos pero con gran poder económico, social, informativo, hasta religioso. Así que el gran desafío en esta nueva etapa de la revolución es crear en cada casa un comité revolucionario, en cada barrio un comité de defensa del gobierno nacional (...) Estamos mucho mejor, listos, con experiencia que hace treinta meses (...) pero no nos engañemos: los enemigos del cambio también ya se

\footnotetext{
${ }^{293}$ Notiamerica.com, 11 de agosto de 2009. Disponible en: https://www.notimerica.com/politica/noticialideres-izquierda-celebran-quito-revolucion-canto-poesia-20090811034918.html

294 Discurso pronunciado por Hugo Chávez Frías en Quito, 10 de agosto de 2009. Disponible en: https:// www.youtube.com/watch?v=Gs4SglRDijE
} 
dieron cuenta que no estamos jugando (...) las oligarquías saben que los pueblos de América Latina están despertando, saben los imperios que se les está yendo de las manos América Latina y por eso, comienzan en su desesperación a no poder vencernos en las urnas, a recurrir a los mismos métodos de siempre (...) brutales, burdos, torpes golpes de Estado como en Honduras, campañas difamatorias como la de Colombia hacia el gobierno ecuatoriano (...) pero no vamos a claudicar, preferimos correr el riesgo, la aventura de ser libres a la nefasta solvencia de los serviles. Los hombres libres de nuestra América sabemos enfrentar valientes, frontalmente a los agenciosos recaderos del imperialismo (...) nuestra responsabilidad histórica es organizarnos (...) Lenin y yo jamás les fallaremos, no nos fallen ustedes. Ni un paso atrás y hasta la victoria siempre. 295

Finalmente, tras los discursos políticos y fuegos artificiales, León Gieco y el grupo portorriqueño "Calle 13" fueron los encargados de cerrar un acto que, nuevamente, mostró cómo el Poder Ejecutivo ecuatoriano se interesó, al momento de proyectar el festejo patrio, tanto por el contenido político-ideológico del mismo, así como por la atracción y el entretenimiento -stricto sensu- de sus espectadores y también -a juzgar por las escenas de Correa cantando "Voy a comerte el corazón a besos" con una de las únicas bandas invitadas cuyas búsquedas estéticas no se han visto interpeladas por preocupaciones en torno a la politización del arte o Chávez jugando e, incluso, coqueteando livianamente con el público- de sus artífices e invitados especiales.

En el caso de Venezuela, es preciso recordar que el principal objetivo que se había propuesto el Poder Ejecutivo con vistas a los festejos bicentenarios era dar cauce a "los saberes, las prácticas y la memoria popular". ${ }^{296}$ Y si bien la jornada del 19 de abril de 2010 estuvo dominada, mayoritariamente, por actos y ceremonias de carácter oficial y protocolar, es posible detectar, durante los días previos al aniversario patrio, algunas puestas en escena y eventos que buscaron materializar aquel objetivo.

Aunque con menor poder de convocatoria y movilización que los recitales desarrollados en Buenos Aires o Quito, el Ministerio del Poder Popular para la Cultura

\footnotetext{
295 Discurso pronunciado por Rafael Correa en Quito, 10 de agosto de 2009. Disponible en: https:// www.youtube.com/watch? $=$ gnLQ x3Bihk
}

296 Decreto $N^{\circ} 6015$ publicado el 17 de abril de 2008 en la Gaceta Oficial N ${ }^{\circ} 38.912$. Los sitios web en los cuales se solía encontrar dicha normativa ya no están disponibles. Véanse fragmentos de éstas en: https://www.albicentenario.com/index_archivos/celebracion_continental_36.html 
planificó para el día 13 de abril en la plaza Venezuela el llamado "Concierto Internacional por la Canción Contestataria" con el fin de celebrar el octavo aniversario del retorno al poder de Chávez luego del golpe de Estado del 11 de Abril de 2002. Isabel Parra, de Chile; Roy Brown, de Puerto Rico; Vicente Feliú, de Cuba; Daniel Viglietti, de Uruguay; así como el grupo de reggae "Raíces y Cultura", de Panamá fueron los artistas internacionales invitados que compartieron escenarios con músicos locales como José Alejandro Delgado, Gasolina, Yakahudawana, Sontizón y la rapera Rodbexa Poleo, devenida dirigente de la Juventud del Partido Socialista Unido de Venezuela.

De esta manera, la curaduría musical efectuada para la ocasión buscó combinar propuestas artísticas que involucraran un arco heterogéneo de ritmos (música popular latinoamericana, blues, ska, rap, reggae, entre otros), pero que también expresaran, en mayor o menor medida, su compromiso con la RB, así como con las políticas de izquierda o progresistas en la región. En este sentido, no resulta extraño que circularan declaraciones como las siguientes:

Estar aquí es natural, es obvio. Esta convocatoria de los países de la izquierda en un momento en que nuestro continente se está derechizando en muchos aspectos a mí en lo personal me interesa. ${ }^{297}$

la música es un factor de unidad que puede seguir uniéndonos como lo han hecho. El haber participado en un evento como este, me parece de suma importancia, porque esto puede servir para que los pueblos latinoamericanos renueven sus compromisos con Puerto Rico, y así podamos lograr la liberación de mi país, que es la última colonia que queda de los estadounidenses. ${ }^{298}$

Siguiendo esta línea, el Poder Ejecutivo organizó para el 18 de abril la "Fiesta de los pueblos del Mundo" en el parque caraqueño Los Caobos -un nuevo concierto musical con invitados nacionales e internacionales-, así como el denominado “Amanecer Bicentenario" para la madrugada del 19 de abril en todas las plazas Bolívar

\footnotetext{
297 Palabras de Isabel Parra citadas en Agencia Bolivariana de Noticias, 13 de abril de 2010. Disponible en: http://juventud.psuv.org.ve/temas/noticias/gran-concierto-por-la-cancion-contestataria-cierra-lacelebracion-del-13-de-abril/\#.XHZ49C3SFmB
}

298 Palabras de Roy Brown citadas en Albaciudad.org, 15 de abril de 2010. Disponible en: http:// albaciudad.org/2010/04/1009/ 
del país -el cual consistió, según el entonces vicepresidente Elías Jaua, en "fiestas populares, fuegos artificiales, jornadas culturales y actividades recreativas y de expresión popular"-. ${ }^{299}$

En cuanto a los festejos del 5 de julio de 2011, la idea de proyectar una celebración de naturaleza popular se vio traducida, nuevamente, en espectáculos musicales que involucraron desde actuaciones de bandas marciales y la Sinfónica de la Juventud Venezolana Simón Bolívar, pasando por las presentaciones de Cecilia Todd, Lilia Vera e Iván Pérez Rossi, hasta la presentación del tradicional grupo de merengue venezolano, "Los Antaños del Stadium”.

A todo ello se sumaron también la escenificación de la firma del Acta de la Independencia, exposiciones de artesanías, pinturas y fotografías, encuentros infantiles, un festival gastronómico en la Plaza El Venezolano, la "buseta rumbera" -a saber, una serie de ómnibus antiguos que recorrieron por la noche las calles del centro de la capital en los cuales la gente podía escuchar y bailar al son de la rumba-, así como la instalación en las inmediaciones de la plaza Bolívar de stands pertenecientes a distintos ministerios y organismos públicos destinados a mostrar productos y servicios dirigidos a los venezolanos.

A su vez, los "IV Juegos del Bicentenario del ALBA" llevados a cabo en distintos estados del país, entre el 17 y 30 de julio, permitieron al gobierno de la RB enlazar, durante el aniversario patrio, deporte, nacionalismo e integración regional. "Si algo bonito han tenido las celebraciones del Bicentenario es que han estado llenas de juventud en deporte, cultura, movimientos sociales. Es la garantía de que la consigna de: 'Independencia para Siempre' es una realidad", ${ }^{300}$ aseguraba el vicepresidente venezolano al hacer referencia a los mismos.

Sin embargo, dos de las actividades más concurridas fueron, por un lado, la marcha de la Juventud Patriótica y Antiimperialista que tuvo lugar el 3 de julio desde la Plaza Madariaga hasta la plaza Miranda dirigida, en un principio, a "conmemorar los

\footnotetext{
299 Palabras de Elías Jaua citadas en Albaciudad.org, 5 de abril de 2010. Disponible en: http:// albaciudad.org/2010/04/gobierno-anuncia-eventos-preparandose-para-la-gran-fiesta-bicentenaria-del-19de-abril/

300 Palabras de Elías Jaua citadas en Radio Cadena Agramonte, 17 de julio de 2011. Disponible en: $\underline{\text { http:// }}$ www.cadenagramonte.cu/articulos/ver/15895:inauguran-en-venezuela-iv-juegos-del-alba
} 
doscientos años de aquel excelente discurso político de nuestro líder Simón Bolívar (...) frente a la Sociedad Patriótica", según explicaba Robert Serra, entonces diputado de la Asamblea Nacional por el PSUV, pero que, finalmente, "cambió su sentido" ya que, en verdad, el pueblo estaba allí para "ratificar su compromiso con Bolívar y con el líder de esta era (...) Hugo Rafael Chávez Frías”, a quien la derecha pretendía “enfermar (...) hacer necropolítica, burlarse del dolor de un pueblo que por primera vez en la historia [amaba] a su líder". 301

Por el otro, cabe destacar el repentino llamamiento a la ciudadanía -efectuado por el entonces vicepresidente Elías Jaua- a concentrarse aquella tarde de julio en los alrededores del "balcón del pueblo" en el Palacio de Miraflores para recibir y escuchar a Chávez. Ante una multitud, el mandatario hizo referencia a una conversación telefónica con Rafael Correa, quien le dijo que se trataba de una nueva batalla que, "como hijo de Bolívar, el hombre de las dificultades", la iba a saber afrontar. Una batalla, afirmaba Chávez a continuación, que

la ganaremos por la vida, por la patria, por la revolución (...) hemos comenzado a vencer el mal que se incubó en mi cuerpo (...) le doy las gracias al dios mío, le doy las gracias al manto de la virgen invocado por mi madre y por las madres de Venezuela (...) a los espíritus de la sabana, aquellos que invocó Florentino Coronado cuando enfrentaba al mismo demonio (...) a Fidel Castro (...) yo me puse y me pongo primero en manos de dios y segundo, en manos de la ciencia médica cubana, venezolana y mundial (...) esta es la hora de la vida (...) de la patria bicentenaria (...) de la independencia definitiva de la patria venezolana, esta es la hora del pueblo venezolano y yo, hijo de este pueblo, no podía faltar a la fiesta bicentenaria de la vida y de la patria, no podía faltar entero, en cuerpo, alma y espíritu. Por eso le doy las gracias a dios, a la virgen y a los santos y a los espíritus de la sabana, a José Gregorio Hernández, a mi cristo redentor (...) a la magia del pueblo, a los médicos (...)

Al exhibir la figura de un cristo que ya había enseñado cuando regresó al Palacio de Miraflores después del intento de golpe de Estado de abril de 2002, el entonces mandatario proseguía:

\footnotetext{
301 Reportaje televisivo realizado a Robert Serra, 3 de julio de 2011. Disponible en: https:// www.youtube.com/watch?v=tiEk5IwJsfE
} 
Este Cristo es el mismo que mostré el 14 de abril, en aquel retorno (...) lo levanto de nuevo, ¡Cristo con nosotros! (...) con la fuerza de la batalla de Carabobo, ese día me pare y salí de la terapia, ese día les digo comenzó el retorno, fue el día de Carabobo, el 24 de junio recordando a Bolívar (...) y aquí estoy pues, apenas han pasado (...) diez días (...) es como un milagro pero que hay cuidar al extremo (...) aquí estamos iniciando el retorno (Chávez, 04/07/2011).

Si bien el discurso político de Chávez presentó desde sus inicios cierto sincretismo entre política y religiosidad popular (Bermúdez y Martínez, 2000), tras el diagnóstico de su enfermedad el líder de la RB profundizaría su concepción metafísica, mística y mítica de la política, en general y la revolución, en particular. En efecto, Chávez aprovechaba las vísperas del bicentenario para enlazar, en clave a la vez religiosa y secular, cuatro momentos o "batallas" que el chavismo consideraba fundamentales para la nación: la de la independencia que culminó con el triunfo en Carabobo en 1821, la de la "segunda independencia" iniciada en 1999 con el éxito electoral del Movimiento V República, el fracaso del intento golpista de 2002 y la última e inesperada batalla contra el cáncer.

Asimismo, es posible identificar, alrededor de ese encadenamiento, un abanico variado de símbolos propios de la religiosidad popular venezolana -la tradición indígena con sus plegarias a los "espíritus de la sabana"-, el cristianismo católico -dios, cristo y la virgen-, la historia patria -la figura heroica aunque también humana de Bolívar, "el hombre de las dificultades" que se impuso en Carabobo- y finalmente, la ciencia médica -“cubana" gracias a la gestión de Fidel Castro y "venezolana" condensada en la figura del científico venezolano, José Gregorio Hernández-.

De modo que si bien los actos más importantes planificados para los dos bicentenarios de "independencia" -es decir, aquellos que se desarrollaron en los días patrios propiamente dichos y contaron con la presencia del Poder Ejecutivo- fueron de carácter oficial, marcial y protocolar, hubo una intención de rodear a las mencionadas celebraciones de formas de sociabilidad popular, la mayoría de las cuales se conjugó, no obstante, con un firme y explícito interés por fomentar la adhesión a la RB y especialmente durante los festejos de julio de 2011- a su principal figura política.

Por último, los repertorios festivos más austeros y acotados de las cuatro 
celebraciones aquí analizadas quizás hayan sido los programados por el Poder Ejecutivo boliviano. En el caso de la conmemoración de la Revolución de Chuquisaca desplegada repentinamente en El Villar, cabe recordar que ésta se inició con espectáculos de baile y música popular, entre los cuales se destacaron la interpretación que hizo el dúo de baladistas "Tupay" de una canción denominada "Cholita"; la presentación de la cantante y guitarrista boliviana Jenny Cárdenas, quien finalizó la canción "Juana Azurduy" aclamando "que viva Juana Azurduy de Padilla, que viva la libertad"; seguido del Pujllay de Tarabuco, tradicional danza folclórica creada a partir de los rituales religiosos paganos en ofrenda a la Pachamama y asociada, posteriormente, a la conmemoración de la victoria del pueblo nativo de Yamparáez sobre los españoles en la batalla de Tarabuco del 12 de marzo de 1816.

En sintonía con el espíritu de la jornada, fue una tradicional fiesta comunitaria andina -teñida de danzas y música folclórica, chicha, vestidos típicos y ritos aymarasla que puso fin a la misma. Así, las actividades pensadas para la participación directa del pueblo convocado en El Villar reforzaron la lectura sobre el proceso de independencia que durante la jornada había ido tejiendo el gobierno del MAS. Alejarse de Sucre y la narrativa criolla también suponía recobrar prácticas recreativas "auténticamente" andinas y populares.

En la celebración paceña llevada a cabo solo dos meses después de la acontecida en El Villar, el mismo giro que había operado sobre el relato histórico trazado por el mandatario boliviano -quien, cabe recordar, esta vez se había inclinado por una narrativa indígena-mestiza de los orígenes de la nación-se vio, igualmente, reflejado en las escasas puestas en escena destinadas a la ciudadanía.

En efecto y haciendo a un lado el hecho de que las actividades centrales fueron, mayoritariamente, de carácter protocolar y oficial, la celebración en la capital boliviana incluyó una "Feria de Identidades" -donde se exhibieron las distintas tradiciones culturales del departamento como la cueca paceña o platos como las llauchas y las salteñas-, el "Desfile cívico del Bicentenario" -encabezado por las autoridades del gobierno central, en el cual desfilaron personas disfrazadas de "criollos" o "damas criollas", "distinguidas damas cívicas", organizaciones indígenas, malabaristas y hasta 
“cebras"-302 y el "Festival Artístico del Bicentenario" en el estadio Hernando Siles donde los espectáculos de melodías y danzas folclóricas de los Andes se combinaron con la presencia de (únicamente) grupos nacionales de música tropical, afroboliviana, pop y rock como "Los Kjarkas", "Veneno" y "Lou-Kass", entre otros-.

De esta manera, de lo que se habría tratado -según el viceministro de Culturas, Pablo Groux - era de proyectar un festejo "100 por ciento boliviano", ${ }^{303}$ lo cual derivó, durante el aniversario del 16 de julio de 2009, en puestas en escena dirigidas a conjugar elementos nacionales propios de las identidades indígenas y criollas, así como de tradiciones populares y prácticas festivas de masas.

Así pues, el recorrido por las aristas "populares" de los festejos del bicentenario puso en evidencia que no siempre fue el factor ideológico lo que predominó en las formas de sociabilidad festivas desarrolladas por los cuatro Poderes Ejecutivos en cuestión. Frente a la concepción de que las fiestas patrias no constituyen otra cosa que simples rituales dirigidos a reproducir la ideología estatal, ha sido posible advertir que, en ocasiones, la utilidad o funcionalidad de éstas radicó en su exclusiva capacidad de distraer y alegrar al pueblo. Todo lo cual no supuso, sin embargo, que no hubiera momentos en que las mismas no fueran aprovechadas para también buscar reforzar la adhesión y legitimidad política o intentar ejercicios de pedagogía cívica.

III. Fiesta y política en los aniversarios patrios. Segundas consideraciones provisorias

\footnotetext{
302 Las "cebras" que circularon aquella noche por las calles de La Paz eran, de hecho, educadores urbanos que, simbolizando las sendas peatonales, solían tener como tarea enseñar a la gente a caminar de manera responsable por toda la ciudad.

303 Bolivia.com, 8 de julio de 2010. Disponible en: https://www.bolivia.com/noticias/autonoticias/ DetalleNoticia41159.asp
} 
Son varios los trabajos sobre "giro a la izquierda" y festejos del bicentenario en América del Sur -algunos de los cuales fueron reseñados en las páginas iniciales de este escrito- cuyas miradas fragmentarias acarrearon ciertos sesgos y uniformidad interpretativos, acabando por esencializar o esquematizar los fenómenos, acontecimientos y/o actores políticos en cuestión. El recorrido hasta aquí efectuado intentó, en cambio, ensayar una mirada integral de los mismos que posibilitara recobrar y repensar la heterogénea y, en ocasiones, conflictiva trama de prácticas, discursos y representaciones que fueron puestas en circulación durante las celebraciones bicentenarias.

Atendiendo a este propósito, el presente capítulo se abocó al análisis de la gran diversidad de prácticas y discursos conmemorativos de carácter protocolar e institucional, así como de formas populares y masivas de festejar la nación desplegadas a lo largo de los diferentes aniversarios patrios, lo cual permitió constatar, en primer lugar, que -a través de ellas- los Poderes Ejecutivos procuraron ciertamente reforzar y legitimar sus proyectos políticos-ideológicos y, en función de eso, discutir y revisar los rasgos que debían configurar las identidades nacionales de cada unidad territorial en ese particular momento histórico, a la vez que exteriorizar una nueva imagen del orden político y social considerada más acorde con el rumbo que aquellos parecían querer imprimir a cada república.

Sin embargo, es preciso destacar que aquel repertorio de actividades festivas y conmemorativas intentó, al mismo tiempo, habilitar instancias de sociabilidad lúdica, ocio e integración social capaces de promover y conjugar nuevos y viejos sentidos históricos, tradiciones, pertenencias y formas de encuentro colectivas.

Por otro lado, la frontera entre esos dos "conjuntos" de puestas en escena resultó más bien porosa e inestable. Lejos de constituir compartimentos estancos u homogéneos estuvieron, indistintamente, cargados de politicidad y diversión, poniendo nuevamente en discusión "la impermeabilidad de los binomios culturalmente construidos y enfrentados, entre lo ‘serio-comprometido' y lo 'lúdico-frívolo”” (Bisso, 2010: 6).

Finalmente y en estrecha relación con lo anterior, creemos que es justamente esa coexistencia y cruce de propósitos, situaciones y escenarios -solo en apariencia accesorios e intrascendentes y/o incompatibles, incoherentes y contrapuestos- lo que 
posibilitará arribar a una caracterización más compleja y real de los modos en que estos gobiernos procedieron durante las celebraciones patrias, disputaron la hegemonía política, difundieron determinadas nociones y creencias e interactuaron con las múltiples identidades colectivas, teniendo siempre presente "la idea de quien hace, el hacedor, no pre-existe sino que se construye invariablemente en y través de su hacer/ acto" (Briones, 2007: 65). 


\section{Capítulo IV}

\section{Bicentenarios en disputa. Los debates y las controversias en torno a la "correcta" narración del pasado nacional}

Es ineludible que toda reactualización de lo nacional se vea enlazada y tensionada con los intereses particulares de sus promotores y eso, a su vez, origine disputas políticas, sociales e historiográficas en el seno de la sociedad. ${ }^{304}$ En efecto, hemos observado a lo largo de los capítulos precedentes los modos en que las narraciones y escenificaciones del pasado nacional -guiadas por criterios normativos y valorativosposibilitaron estructurar ciertas identidades colectivas, ideologías y visiones del mundo que, entre otros objetivos, apuntaron a la autoafirmación y a la cimentación de la hegemonía frente a otros grupos.

En este proceso, los conflictos del presente operaron sobre las formas de restaurar la historia y viceversa; es decir, los diseños de narrativas genealógicas -dirigidas a precisar y visibilizar aquel conjunto de episodios, sujetos y principios que supuestamente habían fundado, una y otra vez, a cada nación- exacerbaron las fisuras y los antagonismos que históricamente las habían dividido, quedando anulada cualquier posibilidad de establecer, durante los aniversarios patrios, una unidad de sentido.

Por consiguiente, los empeños por restaurar las memorias históricas activaron -al involucrar un proceso de reconfiguración identitaria a nivel nacional, pero también político-partidario- un movimiento dialéctico en torno al pasado y su reconstrucción. Si bien las celebraciones bicentenarias intentaron constituirse en momentos de encuentro colectivo, buscando cristalizar -al menos transitoriamente- sentidos de igualdad,

\footnotetext{
$304 \mathrm{Si}$, como sostiene Benedict Anderson, "la nacionalidad es el valor más universalmente legítimo en la vida política de nuestro tiempo" (2013 [1993] :19), entonces cobra sentido que ese valor en cuanto tal constituya un firme y codiciado objeto de disputa y origine, por ende, severas "competencia[s] y (...) debate[s] entre varias lecturas de la historia" dirigidas, cada una de ellas, a influir sobre "los conflictos político-sociales del momento" y, en estrecha relación, sobre "la construcción de un orden político y social" en una época determinada (Cattaruzza, 2007: 19-20).
} 
comunidad y/o libertad, no anularon la presencia de instancias de contestación y resistencia a las interpretaciones oficiales, de las que participaron académicos, periodistas, movimientos sociales y agrupaciones políticas, entre otros.

Este capítulo apunta, entonces, a reflexionar sobre el modo en que las tentativas por montar acontecimientos festivos y narrativas históricas que estuvieran en sintonía con los intereses y/u objetivos de cada Poder Ejecutivo chocaron con realidades complejas y problemáticas, dando lugar a un abanico variado de debates y controversias que ocuparon la escena pública y pusieron de manifiesto las resistencias y oposiciones a la asimilación de los sentidos oficiales desplegados durante los aniversarios patrios.

\section{I. “Un Bicentenario del MAS”. Las polémicas en Bolivia}

Mientras el Poder Ejecutivo iniciaba su retirada hacia el interior rural del altiplano boliviano para celebrar los doscientos años de la Revolución de Chuquisaca, las autoridades opositoras de Sucre se disponían, por su parte, a llevar adelante su propia agenda conmemorativa, ${ }^{305}$ escenario que condujo a diagnósticos como el siguiente:

más allá de la gente que hace suya la celebración, la política se ha adueñado de este acto trascendental y el Bicentenario se ha convertido en un espacio más de la lucha por el poder en Bolivia. Y hoy será un día más de batalla en la guerra no declarada entre el oficialismo y la oposición. ${ }^{306}$

Al ser consultada por un periódico de Santa Cruz qué opinaba sobre la existencia de dos festejos paralelos, la entonces prefecta (gobernadora) de Chuquisaca y ex militante del MAS, Savina Cuéllar, explicaba que esa era "la intención de los radicales,

\footnotetext{
305 El programa oficial de la celebración sucreña, se puede observar en: http://eju.tv/2009/05/ bicentenario-chuquisaca-festeja-en-medio-de-una-divisin-poltica/
}

306 Diario Crítico, sin fecha. Disponible en: https://www.diariocritico.com/noticia/151567/noticias/ bicentenario-en-medio-de-division.html 
dividir a los bolivianos" para luego preguntarse "con qué cara [iba] a llegar Evo Morales a los festejos si no [quería] reconciliarse con la región".307

En esta línea, se ubicaron también las declaraciones del entonces prefecto de Tarija, Mario Cossío, quien señaló que la unidad del país se encontraba "en peligro" y acusó al Poder Ejecutivo de llevar adelante un plan "totalitario" fundado en la persecución política y judicial de los principales líderes opositores. ${ }^{308}$ Asimismo, el prefecto de Santa Cruz, Rubén Costas, acusado en agosto de 2008 de haberse reunido con el embajador norteamericano en el marco de un agudo enfrentamiento entre el gobierno nacional y las autoridades de los departamentos de la llamada Media Luna, sostuvo:

Lamentamos que los mismos de siempre quieran dividir a Bolivia y quieran hacernos aparecer ahora que estamos desencontrados; lamento mucho que hayan querido aguar la fiesta que no es de Sucre ni de Chuquisaca, sino del primer grito libertario de toda nuestra América morena. 309

El ex presidente Jorge Quiroga y líder de Poder Democrático y Social (Podemos) fue otra de las figuras de la oposición que -ante la ausencia del primer mandatario en los actos organizados en Sucre para el 24 de mayo, jornada que había sido proclamada "Día nacional de lucha contra la discriminación racial"- se había mostrado particularmente indignado:

El ex presidente Jorge Quiroga lamentó que Evo Morales haya "insistido en distorsionar y manipular la historia, dividir y dañar a los bolivianos, ofender y dañar a Sucre y en manchar la patria" con la decisión de no asistir a la celebración de la capital y de crear un acto paralelo.

Para el líder de (...) la principal alianza opositora del país, la ausencia del presidente en Sucre es "parte de una campaña sistemática de sabotaje".

${ }^{307}$ El Deber, 24 de mayo de 2009. Recogido por la agencia de noticias Eju.tv. Disponible en: http://eju.tv/ 2009/05/bicentenario-chuquisaca-festeja-en-medio-de-una-divisin-poltica/

308 Los Tiempos, 26 de mayo de 2009. Disponible en: http://www.lostiempos.com/actualidad/nacional/ 20090526/bicentenario-pugnas-no-opacaron-fiesta

309 Los Tiempos, 25 de mayo de 2008. Disponible en: http://www.lostiempos.com/actualidad/nacional/ 20090525/oposicion-critico-ausencia-del-presidente-sucre 
Además, Quiroga tachó de "hiriente" que Morales asistiese (...) al homenaje de los 187 años de la Batalla del Pichincha, que selló la independencia ecuatoriana junto a los mandatarios de Ecuador, Rafael Correa, y Venezuela, Hugo Chávez, en vez de celebrar el bicentenario en Sucre.

"Qué triste que el 24 de mayo el presidente de Bolivia se vaya fuera del país a rendirle culto a su patrón don Hugo Chávez" $(. . .)^{310}$

Así, la retirada a la periferia andina y la reformulación de la historia nacional propuesta por Morales en ocasión del bicentenario de la Revolución de Chuquisaca -la cual, cabe recordar, había enaltecido la narrativa de "la Gran Rebelión Andina", contrarrestando, de ese modo, el protagonismo de la ciudad y la participación criolla en la gesta emancipadora- sentaron las condiciones para que varias figuras de la oposición -todas ellas firmes defensoras de las autonomías departamentales_-311 salieran a la palestra pública culpando al Poder Ejecutivo de fomentar la distorsión de la historia patria, la fragmentación nacional y/o la sumisión de Bolivia al gobierno venezolano.

Uno de los responsables en replicar esta serie de acusaciones fue el portavoz presidencial, Iván Canelas, quien se limitó a señalar

que faltó "mucha sinceridad" en la invitación de las autoridades y los cívicos de Sucre, alineados con la oposición, para rendir homenaje y celebrar de manera conjunta el Bicentenario del primer grito libertario de América.

"Nosotros estábamos plenamente de acuerdo con hacer actos de homenaje de manera conjunta, pero vemos que todavía hay personas, dirigentes, autoridades a los que les falta mucha sinceridad" (...) Canelas aclaró que "los separatistas" no son las autoridades de Gobierno. ${ }^{312}$

310 El Confidencial, 25 de mayo de 2009. Disponible en: https://www.elconfidencial.com/archivo/ 2009/05/25/74_oposicion_critica_morales_dividir_bolivianos.html

311 Resulta pertinente recordar que hacia principios de siglo XX "el Oriente liderizado por Santa Cruz, empieza a adquirir protagonismo, y el mapa regionalista que antes era longitudinal, se vuelve transversal" (Roca 1997: 16). En ese marco y producto de las políticas económicas -principalmente, el tendido de las vías férreas- que significaban el predominio de La Paz y la consiguiente postergación de las tierras bajas, la élite política e intelectual cruceña comenzó a organizarse frente al gobierno central. En este sentido, los reclamos regionalistas y las demandas por la autonomía nacieron en contra del unitarismo centralista aplicado tradicionalmente desde el altiplano (Zalles Cueto, 2006) aunque se vieron especialmente intensificados en las dos últimas décadas producto del creciente poder indígena-popular y nacionalista (Gustafson, 2006).

312 Diario Crítico, sin fecha. Disponible en: https://www.diariocritico.com/noticia/152010/noticias/ bicentenario-en-actos-paralelos.html 
Igualmente, el entonces diputado por el MAS, Jorge Silva, intervino públicamente alegando que -“por dignidad, respeto y responsabilidad”- Morales había decidido ausentarse de los actos organizados en Chuquisaca a fin de evitar los "insultos, agresiones y vejámenes" provenientes de una oposición que apostaba "a la discriminación en el país": 313

El Presidente no participara (sic) a estos actos (sic) por evitar aquellos escenarios de provocación donde puede ser objeto de insultos, agresiones y vejámenes por parte de una elite sucrense (...)

El Presidente participará en un acto que se está programando en la comunidad de El Villar, donde estará con el pueblo, con los campesinos, con los indígenas y con los estudiantes $(\ldots)^{314}$

De modo que, sin la presencia de las autoridades nacionales y bajo un clima de abierta conflictividad, los actos "opositores" del 25 de mayo se inauguraron en Sucre a primera hora de la mañana con una ofrenda floral al pie del monumento al héroe criollo de la revolución de 1809, Jaime Zudáñez, y con un tedéum, en donde el arzobispo de Chuquisaca, monseñor Jesús Pérez, aprovechó la ocasión para sumarse a las críticas dirigidas al gobierno central al advertir que esa "fiesta departamental, con carácter nacional y continental" había servido para dar cuenta "que pese al esfuerzo que han realizado los gobiernos y los habitantes chuquisaqueños del campo y de la ciudad, la postergación dentro del contexto nacional [continuaba]".315

La jornada patria prosiguió con un desfile cívico ante la Casa de La Libertad, en el cual, según una nota titulada "Bicentenario: Civismo de Sucre se impuso a la consigna política", "también hubo ponchos multicolores y hasta caballos". ${ }^{316}$ No obstante ello, la misma fue vista, del lado del oficialismo, como una reunión de la oposición en tanto sus invitados principales habían sido miembros de la Corte Suprema de Justicia, prefectos y

313 Hoy Bolivia, 23 de mayo de 2009. Disponible en: http://hoybolivia.com/Noticia.php?

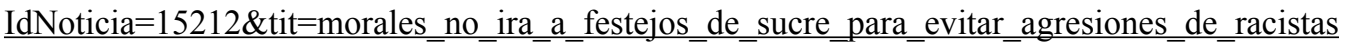
314 Ibídem.

315 Diario Crítico, sin fecha. Disponible en: https://www.diariocritico.com/noticia/152010/noticias/ bicentenario-en-actos-paralelos.html

316 Centro de Investigación y Apoyo Campesino, 26 de mayo de 2009. Disponible en: http://www.ciacidr.com/index.php?p=2384 
dirigentes opositores y autonomistas de los departamentos de Santa Cruz, Beni y Tarija, así como los ex presidentes Jaime Paz Zamora y Jorge Quiroga, entre otros.

Más aún, el acto organizado por las autoridades de Chuquisaca y Sucre llegó a ser calificado -por las agresiones que un año antes había sufrido aquel grupo de campesinos- como una "asamblea del racismo".317 En esta dirección, se enmarcaron las declaraciones de Isaac Ávalos, principal dirigente de la Confederación Sindical Única de Trabajadores Campesinos de Bolivia, quien, durante los actos de desagravio planificados para el 24 de mayo, sostuvo:

Quienes nos humillaron el año pasado, son los mismos responsables de sembrar terrorismo en Bolivia. Ellos son los que cometieron delitos en nuestro país y deben ir a la cárcel. Todos los prefectos y cívicos de la media están comprometidos y son los que no quieren la unidad de nuestros pueblos. ${ }^{318}$

De esta manera, si para el oficialismo fueron las acciones del movimiento indígena fraguadas en la montaña las que funcionaron como puntapié del proceso de independencia -razón por la cual debían ser justamente enaltecidas durante el primer bicentenario patrio-, para los sectores opositores el inicio de la gesta emancipadora había sucedido “en La Plata (...) donde se produjo la 'chispa' de la insurrección en América con un levantamiento de la intelectualidad y la naciente burguesía contra el presidente de la Audiencia de Charcas". 319

Esta diferencia de criterios en la forma de concebir y presentar los hechos revolucionarios vino acompañada de otra discrepancia ligada a las disputas sociales y políticas que atravesaban a la Bolivia de entonces. Es así que, en plena reactivación de los conflictos regionales y étnicos que históricamente marcaron la vida de esta nación, los segundos condenaron la lectura oficial del pasado independentista pero, sobre todo, la decisión de conmemorarlo fuera de Sucre, atribuyéndole al Poder Ejecutivo afanes

\footnotetext{
317 Así habría sido calificada por el diputado oficialista Jorge Silva. Ibídem.

318 Europa Press, 24 de mayo de 2009. Disponible en: https://www.europapress.es/internacional/noticiabolivia-indigenas-protestan-contra-racismo-actos-bicentenario-primer-grito-libertariosucre-20090524223735.html
}

319 Los Tiempos, 25 de mayo de 2009. Disponible en: http://www.lostiempos.com/actualidad/nacional/ 20090525/bicentenario-bolivia-libre-pero-dividida 
separatistas y pendencieros. Naturalmente, el gobierno del MAS invertiría esa acusación, excusando su accionar en lo sucedido el 25 de mayo de 2008 en Sucre y presentando su revisión de la historia patria como una suerte de acto de justicia historiográfica.

Este fuego cruzado de acusaciones volvería a aparecer en el marco de la celebración de los doscientos años de la Primera Junta Tuitiva de Gobierno desplegada el 16 de julio de 2009 en La Paz. En efecto, el entonces presidente del Senado, Óscar Ortiz aseveraba, frente a lo que él consideraba un exceso de pompa festiva, que Morales creaba "circo" pero no daba "pan al pueblo". Asimismo, acusaba al gobierno de "vivir en campaña" y de aprovechar el aniversario patrio "para reunirse con Chávez y su comparsa", descuidando las problemáticas sociales y económicas que aquejaban a la nación. ${ }^{320}$

De igual modo, Jorge Quiroga intervenía nuevamente en la escena pública a fin de expresar su "profunda decepción por la utilización del Bicentenario paceño para profundizar la división entre bolivianos y así demostrar el servilismo a Hugo Chávez (...)".321 "Es la fiesta de La Paz y nada tiene que ver con Zelaya ni Chávez", habría opinado el líder de Podemos, mientras otras figuras opositoras se preguntaban "si en vez del festejo del Bicentenario del grito libertario de La Paz lo que se celebraba en realidad era el cumpleaños de Evo". ${ }^{322}$

Aunque con menor resonancia, también surgieron voces críticas dentro del campo historiográfico, así como literario que cuestionaron el "revisionismo histórico" en el que se habría embarcado el Poder Ejecutivo en ocasión de las celebraciones bicentenarias. El historiador de origen cruceño, Alcides Parejas, afirmaba, así, que

la revolución paceña del 16 de julio, que tiene una gran importancia en el proceso histórico americano, se ha convertido en un instrumento político del Movimiento Al Socialismo (...) El festejo es el reflejo de lo que Morales propone para el país: una política excluyente que, negando la historia, pretende crear una gran ayllu (...)

\footnotetext{
${ }^{320}$ El Día, 17 de julio de 2009. Disponible en: https://www.eldia.com.bo/index.php? cat $=150 \& p l a=3 \&$ id articulo $=10344$

321 Ibídem.

322 El Día, 17 de julio de 2009. Disponible en: https://www.eldia.com.bo/index.php? cat $=1 \&$ pla $=3 \&$ id articulo $=10343$
} 
a partir de la cultura aymara. Busca eliminar los resquicios coloniales y, al mismo tiempo, emprende una nueva colonización a partir de la cultura aymara. Propone un nuevo Estado, que ya no es una república, sino uno plurinacional excluyente que no abarca todo el territorio y en el que se reniega de todo lo que es la historia de los últimos 500 años. $^{323}$

En esta línea, el poeta y novelista oriundo de Beni, Ruber Carvalho, condenaba la reformulación de la historia que el gobierno del MAS había efectuado durante los festejos patrios, alegando que se trataba de un mecanismo más para profundizar su "política racista y aymarista":

no es el Bicentenario de La Paz o de Chuquisaca, es un Bicentenario del MAS, así de simple y así de absurdo.

Y aquí hay dos connotaciones, una es que lastimosamente el Presidente ha visto en esta fecha del Bicentenario una venganza política a Chuquisaca y la segunda es que dentro de la política racista y aymarista que está imprimiendo de supremacía aymara, está tergiversando la historia. La revolución latinoamericana de la independencia en todo el continente no tuvo nada que ver con lo indígena, con el movimiento de Tupac Amaru en el Perú, de Tupac Katari son movimientos de reivindicación indígenas que no tienen nada que ver con la independencia, aquí quienes se alzaron, no fueron los indígenas que participaron con los españoles como los sublevados, sino fue la clase media, el criollaje, los hijos de los españoles, fue el mestizaje. 324

Aunque desde las antípodas de este tipo de declaraciones, quien también se habría mostrado crítico con la Revolución Democrática y Cultural, sus políticas simbólicas y su forma de encarar el proceso de "descolonización" -y, por ende, es posible inferir, con el modo en que aquella reformuló la memoria histórica de la nación en tiempos de bicentenario- fue una parte del movimiento indígena disidente -englobado principalmente dentro del katarismo- para el cual ni la administración del MAS ni la

\footnotetext{
${ }^{323}$ El Pais. 15 de julio de 2009. Disponible en: https://elpais.com/internacional/2009/07/15/actualidad/ $\underline{1247608817850215 . \mathrm{html}}$

${ }^{324}$ El Día, 16 de julio de 2009. Disponible en: https://www.eldia.com.bo/index.php?

cat $=360 \&$ pla $=3 \&$ id_articulo $=10266$
} 
entonces reciente Constitución Política del Estado estaban contribuyendo a una auténtica destrucción del entramado colonial en Bolivia. ${ }^{325}$

De esta forma, Pukara -un editorial aymara y quechua opositor al gobierno del MAS- sostenía en ocasión del bicentenario de la Revolución del 16 de julio que

Antes del actual período de «cambio en democracia», el 25 de mayo y el 16 de julio eran fechas en las que salían a relucir los antagonismos de las chatas oligarquías chuquisaqueñas y paceñas.

Ahora, en el gobierno del MAS y de Evo Morales, las cosas no han cambiado sustancialmente. El artificio solamente se ha enriquecido con nuevas y exóticas poses. Antes, Chuquisaca se caracterizó por su racismo y el marginamiento total y absoluto de los indígenas. No en vano su bandera departamental es la misma con la que el ejército español arremetió contra los pobladores originarios: la bandera de la Cruz de Borgoña. Ahora, en Sucre se continúa pateando y humillando indígenas, bajo pretexto de que así combaten a Evo Morales y al MAS.

Antes, La Paz tuvo como caudillo libertario a un perseguidor y carcelero de indios, que luego propugnaba la incorporación de originarios a su revolución, aun cuando en su Junta Tuitiva no incluyeron a ningún indígena. Ahora, el occidente boliviano - La Paz como epicentro - proclama como gobierno indígena a una administración en la que ejecutan los mismos que mandaron y gobernaron siempre. Antes como ahora, el indígena es relleno y carne de cañón.

Lo que cambia ahora es la conducta del poder ejecutivo. En épocas pasadas todo presidente ostentaba una prudente e hipócrita imparcialidad en ese criollo antagonismo. Ahora, aunque Evo Morales ha sido claro en la denuncia y falsedad del 25 de mayo, ha callado dócilmente respecto al 16 de julio. En Chuquisaca ha rememorado esa fecha en las comunidades indígenas; en La Paz ha encendido en la Plaza Murillo la "tea de la libertad", iniciando así los festejos del bicentenario de la mustia oligarquía paceña. ${ }^{326}$

Tiempos después en La Paz, durante un congreso denominado "Historia, Coyuntura y Descolonización" organizado por el mencionado periódico, Marina Ari

\footnotetext{
325 Si bien estas intervenciones ocurrieron casi un año después de las celebraciones bicentenarias propiamente dichas y frente a la dificultad de hallar en los principales medios de comunicación bolivianos declaraciones de estos actores pronunciadas al calor de dichos acontecimientos, se recogen igualmente estas opiniones en la medida que posibilitan inferir y reconstruir los principales cuestionamientos a las políticas culturales y simbólicas de la RDC por parte del movimiento indígena disidente.
}

326 Pukara, 15 de julio al 14 de agosto de 2009. Disponible en: http://www.periodicopukara.com/ archivos/pukara-43.pdf 
Murillo -especialista en la participación de las mujeres aymaras en la historia y la cultura qulla - afirmaba que el MAS no representaba "al katarismo y que el proceso de descolonización” no existía. “QQué es lo que existe?”, se preguntaba a continuación la intelectual y militante afro-indígena, "un proceso de disfrazamiento, de redomesticacion (sic)" (2010: 88), en donde más allá de su integración a la memoria histórica de la nación, la incorporación real de las mujeres aymaras, por ejemplo, era aún una cuenta pendiente:

Otro elemento a definir es el chacha warmi. Es decir, hacer real la incorporación de las mujeres aymaras, iporque ahora el gobierno está luchando porque se realice el concurso de Miss Universo en Bolivia!: Eso ilustra el concepto de proceso de descolonización que tiene el MAS, cuál es su idea de incorporación de la mujer aymara (2010: 89).

La lectura del pasado independentista, así como los elogios a Simón Bolívar asiduamente proferidos por el Poder Ejecutivo también fueron objeto de críticas en ese mismo congreso por parte de varios de los expositores. Constantino Lima Chávez fundador del Movimiento Indio Julian Apaza (MUJA), del Partido Autentico Nacional (PAN), del Movimiento Nacional Tupak Katari (MNTK) y del Movimiento Indio Tupak Katari (MITKA)- cuestionaba “Qué tipo de 'descolonización' puede ser eso, cuando ese Bolívar — de donde viene Bolivia — nos ha desconocido, como a animal, como a objetos nos ha tratado ¿y yo voy a estar respetando a ese cabrón?” (2010: 70).

Asimismo, José Luis Saavedra -académico y ex funcionario del MAS devenido opositor- incluía dentro de "los principales hitos de la continuidad colonialista en el contexto republicano" a "los famosos decretos de Bolívar, el «libertador», aboliendo la comunidad indígena, proscribiendo la vigencia de las autoridades originarias y promoviendo la propiedad privada" (2010: 174). Por su parte, Felipe Quispe Huanca, dirigente campesino y líder del disuelto Movimiento Indígena Pachakuti (MIP), también se preguntaba

¿qué hace Simón Bolívar acá?, ¿nos ha libertado a nosotros? No, más bien nos ha impuesto, ha habido asientos, el qamana, el islero el, awatiri, el aljiri..., todos hacían el trabajo gratuito para los criollos, que eran como los que ahorita están en 
el palacio de gobierno, los que están en los ministerios, para ellos y sus abuelos (2010: 202)

Por su parte, Pedro Portugal Mollinedo, director del aludido periódico, refutaba la interpretación oficial de la gesta emancipadora delineada por el Poder Ejecutivo durante los actos en El Villar al considerar que

Si bien en lo que actualmente es Bolivia los pueblos originarios han sido invadidos y colonizados y si bien ellos han resistido y luchado por liberarse de ese yugo, estos pueblos no han expulsado a los españoles y establecido su independencia. La "independencia" ha sido obra de los criollos, de los hijos de los españoles, quienes mantuvieron y en muchos casos empeoraron la situación colonial en estas tierras (2010: 93)

Esto, a su vez, lo llevaba a cuestionar el carácter superficial, impostado e hipócrita del indigenismo del gobierno del MAS:

El entorno que hizo a Evo Morales presidente y que ahora gobierna en su nombre, se dio cuenta de que tenía en sus manos un billete premiado: el origen y el rostro de su presidente. Y se apresuraron en cobrar ese billete, haciendo jugar a éste roles que seguramente nunca se había imaginado. Así, se recuperan banderas indianistas y kataristas, pero sólo en el plano simbólico y de discurso, pues el resto de la política sigue pautas más clásicas y bolivianistas (...)

Esta administración no puede dar respuestas porque es demasiada ambigua, demasiada confusa. Busca contentar a todo el mundo y trata fundamentalmente de conservar su poder, así sea aliándose con la Unión Juvenil Cruceñista y, al mismo tiempo, disfrazando a nuestro presidente en sus ceremonias de entronización en Tiwanaku. Trata de mantenerse como sea, aún a costa de la demagogia y del descrédito. (2010: 97-100)

Así pues, las celebraciones del bicentenario en Bolivia no solo sentaron las condiciones para volver a discutir en torno a las características de la revolución de "independencia", así como polemizar sobre quiénes habrían sido sus auténticos precursores, sino también para discurrir sobre la naturaleza del gobierno del MAS. Para varios referentes y académicos vinculados al movimiento indígena opositor al gobierno del MAS, lo que había quedado en evidencia era la política anti-indigenista y colonial 
de la RDC, lo cual los llevaba a considerarlo como un sustituto más de los regímenes republicanos y neoliberales que, históricamente, habían gobernado en Bolivia.327

Respecto a las condenas provenientes de los sectores vinculados a la llamada Media Luna, bajo el argumento de estar resguardando, en última instancia, la unidad de la patria, estos desaprobaban dos aspectos -estrechamente relacionados entre sí- que, a sus ojos, las narrativas históricas delineadas por el Poder Ejecutivo nacional habrían puesto de manifiesto: el intento por asegurar la preeminencia de La Paz sobre el resto del territorio nacional y la desmesurada e, incluso, nociva retórica y práctica de reafirmación indigenista.

\section{II. “La voz 'guayaquileña' de quienes no mienten". Las polémicas en}

\section{Ecuador}

Meses antes de que la celebración del bicentenario de la Primera Junta de Gobierno de Quito tuviera lugar comenzaron a aflorar y circular ciertas voces dirigidas a discutir la lectura del pasado independentista que estaba siendo difundida en ocasión del aniversario patrio por el Poder Ejecutivo, así como por algunos historiadores profesionales alineados a éste y/o vinculados a la organización de la efeméride.

Puntualmente, fue la reedición, a principios de 2009, del libro Historia de Guayaquil de Efrén Avilés (Director del Archivo Histórico del Guayas) y Melvin Hoyos (Director del Museo Municipal de Guayaquil) el puntapié de un acalorado debate historiográfico y político-ideológico, en el que también participó el primer mandatario ecuatoriano:

El texto fue descalificado por el presidente Rafael Correa en el enlace sabatino de la semana pasada, en el que amenazó con prohibir la entrega gratuita de esa

\footnotetext{
327 Para profundizar en estos debates, se sugiere consultar la compilación de las exposiciones efectuadas durante el panel "Historia, Coyuntura y Descolonización", que organizó el Periódico Pukara en el Museo de Etnografía y Folklore en la ciudad de La Paz, los días 10, 11 y 12 de marzo de 2010. Disponible en: http://www.rebelion.org/docs/123329.pdf
} 
publicación por parte de Alcaldía guayaquileña, por considerarla atentatoria contra la imagen de Simón Bolívar.

En el libro este personaje es calificado como un usurpador que tomó a Guayaquil amenazando con su ejército, en un momento en que la provincia estaba indefensa. "A Bolívar le molestaba que Guayaquil se hubiera independizado sin su ayuda; y olvidaba, o no quería recordar (...), que esos guayaquileños a los que llamaba afeminados y nada militares eran quienes habían luchado para darle la libertad de la Audiencia de Quito", reza un fragmento del texto. 328

De igual forma, en lo que fue calificado como una "disputa menos que pueblerina" surcada por "interpretaciones reduccionistas motivadas por el sectarismo o la ignorancia”, el entonces Rector de la Universidad Andina Simón Bolívar y miembro del Partido Socialista, Enrique Ayala Mora, ${ }^{329}$ intervino -a través de un editorial publicado en un periódico de tirada nacional- afirmando que

Los grandes procesos históricos rebasan constantemente sus propios horizontes. Por ello es absurdo tratar de ver si un hecho histórico fue "más independencia" que otro. Solo personas de escasa o ninguna formación profesional como historiadores pueden poner en oposición el 10 de Agosto de 1809 con el 9 de Octubre de 1820, afirmando que el primero no fue independencia y el otro sí. En realidad, ambos son parte de un mismo proceso libertario, que fue madurando desde sus inicios con la Revolución de Quito, hasta que con la proclamación de Independencia de Guayaquil se inició la fase final, que culminó con la batalla del Pichincha y el fin del coloniaje en nuestras tierras (...)

es muy importante constatar que, en su tiempo, los patriotas que fueron actores de los hechos no vieron sus esfuerzos libertarios como aislados o contrapuestos. (...) Vieron la Independencia como una lucha global que requería el esfuerzo de varios pueblos y sectores sociales. Fueron solidarios y pensaron no solo en sus localidades, sino en el país que estaban formando. Desecharon el parroquianismo y dieron un ejemplo de unidad que debemos seguir. 330

328 El Universo, 9 de agosto de 2009. Disponible en: https://www.eluniverso.com/2009/08/09/1/1355/ bicentenario-enciende.html

329 Vale destacar el posterior giro opositor de Ayala Mora, para quien el gobierno de Correa "se volvió un caudillismo abusivo como los que han azotado el Ecuador desde su fundación". El Comercio, 25 de diciembre de 2015. Disponible en: http://www.elcomercio.com/opinion/volver-pasado-restauraciondeuda-enriqueayalamora.html

330 El Comercio, 19 de junio de 2009. Disponible en: http://puce.the.pazymino.com/

disputa_independentista_enrique_ayala_mora.html 
Cercano a la postura de Ayala Mora, Juan Paz y Miño -historiador y secretario del Comité Ejecutivo creado por el gobierno nacional para el aniversario patrio-, recordaría, tiempo después, que el bicentenario había sido polémico

porque en algunos países surgieron revisionismos históricos como en el caso ecuatoriano. Algunos escritores en Guayaquil han minimizado a la Revolución de Quito por considerar que la Revolución del 9 de octubre de 1820 es la única que proclamó Independencia. 331

De hecho, Paz y Miño había sido uno de los primeros en intervenir públicamente y llamar la atención, en aquel entonces, sobre el mencionado "texto destinado a la enseñanza en los planteles de Guayaquil y distribuido en forma gratuita por el Municipio de esa ciudad", alegando que

todo ecuatoriano sensato, con un mínimo de conciencia patria, tiene que preguntarse ¿cuál es la intención de presentar una versión de la historia antiquiteña? (...) ¿Qué pensarán los pueblos latinoamericanos sobre el Bolívar "descubierto" en esta versión de una historia simplemente local? ¿Cómo es posible que la figura más universal de América Latina, reconocida incluso en el mundo, quede a nivel de un intrigante, rencoroso, usurpador, enemigo y vil conculcador de la "libertad" de Guayaquil? (...) ¿Qué causa autonomista de Guayaquil se defiende e interpreta? Porque los ecuatorianos y ecuatorianas debiéramos entender, claramente, que existe un tipo de "autonomismo" oligárquico escondido tras las legítimas e históricas aspiraciones libertarias del pueblo guayaquileño, a las que, en cambio, no se atiende. (...)

Seguidamente, el historiador volvía a proponer un último interrogante para concluir que, en verdad, aquel escrito no era otra cosa más que un instrumento dirigido a afianzar el poder de la "oligarquía" guayaquileña:

¿Se trata de una especie de versión "oficial" de la historia guayaquileña desde la perspectiva del socialcristianismo? Muchas dudas quedan al saber que Melvin

331 Ecuador Inmediato, 8 de julio de 2014. Disponible en: http://www.ecuadorinmediato.com/index.php? $\underline{\text { module }=\text { Noticias } \& \text { func }=\text { news user } \text { view } \& \text { id }=2818765769}$ 
Hoyos es arquitecto y, además, Director de Cultura y Promoción Cívica del Municipio de Guayaquil.

Si pueden quedar preguntas abiertas en el campo de la historia, ninguna duda existe en el campo político: desde la década de los noventa del siglo pasado, la hegemonía del Partido Social Cristiano en Guayaquil fue imbatible (...) una hegemonía totalitaria, en la que la obra municipal, el "autonomismo" y el "modelo económico" socialcristiano local no podían ser cuestionados por nadie. (...)

Al fin y al cabo, todo investigador social sabe bien que en historia hay múltiples interpretaciones. También las oligarquías, los grupos de poder, las capas dominantes, hacen su propia historia y tienen derecho a su propia versión de la misma. 332

De modo que tanto este último como Ayala Mora rechazaban de plano aquella obra historiográfica que, en las vísperas del aniversario patrio, volvía a irrumpir en la escena pública a fin de relativizar el lugar de la revolución quiteña en el proceso independentista, así como reivindicar y legitimar el movimiento autonomista liderado por el Partido Socialcristiano.

Ahora bien, más allá de la centralidad que terminó adquiriendo el debate en torno a la reedición de Historia de Guayaquil, las críticas a la narrativa histórica defendida por el gobierno de la Revolución Ciudadana y al modo en que éste había proyectado la celebración bicentenaria involucraron, asimismo, a otros actores. En efecto, un polémico artículo del diario opositor El Universo titulado "El bicentenario se enciende" había afirmado que la celebración, "pese a ser nacional", estaba pasando "casi desapercibida en el resto de provincias y que al coincidir con un momento de tensión política" había "revivido el debate por las lecturas regionalistas del proceso de liberación del país."333

Allí, Wellington Paredes, asesor académico del Archivo Histórico del Guayas, aseveraba que lo que, en verdad, estaba sucediendo era "la sobrevaloración del 10 de Agosto de 1809 contra su desvalorización", al tiempo que alertaba sobre las

332 Ecuador Inmediato, 23 de abril de 2009. Disponible en: http://the.pazymino.com/ HISTORIA_Guayaquil.pdf

333 El Universo, 9 de agosto de 2009. Disponible en: https://www.eluniverso.com/2009/08/09/1/1355/ bicentenario-enciende.html 
consecuencias de denominar "a todo el proceso independentista, desde 1809 hasta el 24 de Mayo de 1822, como Revolución Quiteña":

La primera visión (...) ubica la acción independentista no como un proceso en el que participaron diversos actores, sino fundamentalmente en el 10 de Agosto y con la élite quiteña como protagonista. Esta (...) se refleja en publicaciones como Breve Historia Contemporánea del Ecuador, publicada en 1994, donde las guerras de Guayaquil y Cuenca (el 9 de Octubre y 2 de Noviembre de 1820, respectivamente) no son consideradas revoluciones, sino solo alzamientos. (...) $)^{334}$

En esa misma línea, otra académica consultada por ese periódico alegó la necesidad de "crear un debate nacional para saber qué pasó con las mujeres en esa época, con la gente del Oriente, de la Costa, porque no solo estuvieron quiteños". 335 Argumento que fue acentuado por un funcionario regional: "No nos sentimos identificados con esta celebración, que está concentrada en Quito, como siempre". 336

Estas querellas historiográficas en torno al análisis del proceso independentista ecuatoriano condujeron a otro debate, el de la pertinencia y legitimidad de los usos políticos del pasado. Es que lo que para muchos resultaba "injustificable" era la utilización política que el Poder Ejecutivo había hecho de la celebración y la "carga ideológica" que había pretendido imprimirle a la misma, lo cual se habría visto especialmente reflejado en una propaganda radial que circuló durante aquellos días patrios en la que se rememoraba el derrocamiento del ex presidente y opositor al gobierno de la RC, Lucio Gutiérrez. ${ }^{337}$

Así pues, el sociólogo Gaitán Villavicencio, también entrevistado por el mencionado diario, señalaba que hubo una "manipulación mediática desde el poder, una apropiación irreverente y torpe de la historia para reforzar la ideología política partidista

\footnotetext{
334 Ibídem.

335 Palabras de una profesora de Historia de la Universidad Laica Eloy Alfaro de Manta. Ibídem.

336 Palabras del vicepresidente de la Casa de la Cultura de Manabí, Douglas Vaca. Ibídem.

337 Ibídem.
} 
(...) con esa forma de manejo de la celebración libertaria se están fomentando las separaciones y polémicas innecesarias y regionalistas". 338

La respuesta a esas acusaciones provino, nuevamente, de Paz y Miño, quien sostuvo que aquello no era "nada malo", sino algo que ocurría "en todos los países, porque los gobiernos también celebran desde su perspectiva política”, lo cual debía ser considerado como "legítimo". Y también de Pablo Salgado, Director de Promoción del Ministerio de Cultura, quien al ser consultado sobre cómo se vinculaba el derrocamiento de Lucio Gutiérrez con la independencia, defendió: "Es parte de nuestra memoria histórica (...). No debemos olvidar los gobiernos que fueron nefastos para el país, para construir un país libre, que queremos vivir a plenitud un proceso de cambio y transformación". 339

Así, los históricos conflictos regionales - marcados por la rivalidad entre la costa y la región andina- y político-partidarios -los cruces entre el socialcristianismo, el correísmo y, también, como veremos a continuación, la izquierda opositora- se tradujeron, durante las celebraciones bicentenarias, en agitados debates y altercados historiográficos que no solo se leyeron y observaron en los medios de comunicación, sino que también se vieron expresados en algunos de las reuniones académicas programadas para ese año.

La primera de ellas fue el llamado Encuentro de Historiadores "Camilo Destruge", el cual -acontecido en Guayaquil durante los días 22 y 23 de mayo de 2009- sirvió de escenario para reanudar las pugnas regionalistas. Es que el historiador Efrén Avilés, uno de los autores de Historia de Guayaquil, participó con una ponencia denominada “1820: la verdadera historia de la independencia”, argumentando que

fue en Guayaquil donde se dio el Primer Grito de Independencia del Ecuador y que la victoria se logró el 9 de Octubre de 1820.

Añadió que la revolución del 10 de agosto de 1809 fue tan carente de principios ideológicos y de conceptos políticos, que 75 días después le devolvió la Presidencia de Quito al mismo gobernante que ella había destituido. "En

\footnotetext{
338 Ibídem.

339 Previo a esas palabras y frente a la pregunta sobre si el gobierno no había utilizado al bicentenario políticamente, Salgado respondía: "En todas esas actividades hay una participación política. El proceso independentista que se vivió en esos años se sigue viviendo ahora, en un proceso emancipador, que es político, pero no partidista."
} 
consecuencia, lo que se va a celebrar este año es, simplemente, el bicentenario del 10 de agosto. Así, a secas, como cualquier otra fecha" $(\ldots)^{340}$

Otro historiador y miembro de la Academia Nacional de Historia, Jorge Núñez, recordaba en una carta pública -divulgada en el marco de una polémica con Avilés meses después- que, durante la reunión académica en cuestión, este último había dado

lectura a su ponencia (...) rodeado de un grupo de regionalistas odiadores que había llevado en su respaldo. En su exposición habló menos del tema señalado y más del 10 de agosto de 1809, que se le ha convertido en una verdadera obsesión, por el enfermizo espíritu localista que lo mueve (...) dijo tales barbaridades que me vi en el caso de rebatir (...) algunas afirmaciones verdaderamente absurdas de Avilés, así como su infame acusación de que el Libertador Simón Bolívar fue "un traficante de armas".

A continuación, Núñez habría proseguido a demostrar, "con citas textuales y documentales" que, en realidad, Guayaquil no había sido incorporada

"manu militari” por Simón Bolívar, sino que tomó al puerto bajo la protección de Colombia (...) que Guayaquil no se liberó únicamente con sus propios medios (...) sino que lo logró con ayuda de las fuerzas colombianas enviadas por Bolívar (...) Y finalmente (...) que Bolívar no vendió armas a la Junta de Guayaquil, sino que ambas partes firmaron un convenio de contingentes, por el que acordaron compartir por igual los gastos de equipamiento de las tropas.

Finalmente, el historiador recordó "un curioso incidente" en el que

algunos de los regionalistas amigos de Avilés (...) gritaron mueras a Bolívar, provocando con ello la reacción de muchos maestros y estudiantes (...), quienes lanzaron reiterados vivas a Bolívar e hicieron callar a los cuatro malcriados amigos de Avilés. ${ }^{341}$

\footnotetext{
${ }^{340}$ El Universo, 25 de mayo de 2009. Disponible en: https://www.eluniverso.com/2009/05/25/1/1380/ AE4380ADAAB14C689CC71A8D2FE234B3.html

${ }^{341}$ Ecuador Inmediato, 21 de agosto de 2009. Disponible en: http://www.ecuadorinmediato.com/Noticias/ news_user_view/

historiador_jorge_nunez_responde_desde_la_anh_la_enfermedad_de_efren_aviles_es_el_odio_que_lo_c arcome--111114
} 
Esta intervención, que evocaba el singular desacuerdo académico ocurrido en la ciudad costera, habían salido a la luz luego de que Avilés redactara otra controvertida misiva pública dirigida al director del diario Expreso de Guayaquil, en la cual comunicaba su salida de la Academia Nacional de Historia aduciendo los siguientes motivos:

Lo que entonces consideré que era un honor, poco a poco me ha ido decepcionando, y hoy me siento avergonzado de pertenecer a una institución (...) que no es otra cosa que una camarilla que congrega y obedece -salvo muy pocas y honrosas excepciones, la mayoría de ellas guayaquileñas- a un grupúsculo de "doctores" en historia que -comenzando por Jorge Salvador Lara y pasando por Enrique Ayala Mora hasta culminar con Juan Paz y Miño y Jorge Núñez Sánchez, entre otros de origen serrano- la falsean sin rubor y (...) la ocultan y tergiversan para satisfacer egoístas vanidades; historiadores que a cambio de prebendas guardan cobarde y cómplice silencio, y aceptan como válidas las propuestas falsas e indocumentadas de esos "doctores" que, abrumados por la verdad y su ninguna capacidad de investigación, por simple revanchismo regional, plañideramente exigen que se calle la voz "guayaquileña" de quienes no mienten, y lloran por que se prohíba la entrega y lectura de libros -como es el caso de la "Historia de Guayaquil" (...)-, simplemente porque en esos libros se dicen verdades históricas que ni al Gobierno -engañado por los "doctores"- ni a los "doctores" -engañados por su vanidad- les gustan. ${ }^{342}$

Tiempo después, llegaba el turno del VII Congreso Ecuatoriano y IV Congreso Sudamericano de Historia desarrollado entre el 27 y 31 de julio de 2009 y organizado por la Universidad Andina Simón Bolívar, la Casa de la Cultura Ecuatoriana, el Taller de Estudios Históricos y la Asociación de Historiadores del Ecuador, el cual contó, a su vez, con el auspicio del gobierno ecuatoriano a través de los Ministerios de Cultura y de Educación.

Ayala Mora, organizador del evento, explicó -en clara sintonía con las narrativas oficiales que serían exhibidas durante el festejo patrio- que el objetivo del encuentro era

\footnotetext{
342 Ecuador Inmediato, 21 de agosto de 2009. Disponible en: http://the.pazymino.com/EI-
} SegundaCarta_EAviles.pdf 
valorar a los héroes de la Independencia, a los padres fundadores de esta República -eso es una continuidad-, pero queremos también establecer una ruptura, es decir, no solamente festejar a los notables y su acción sino también la presencia del pueblo: de los vendedores ambulantes, las vendedoras del mercado, los pequeños comerciantes, y los artesanos de Quito (...) y, desde luego, de las mujeres, los sectores populares como los negros esclavos que tuvieron un papel decisivo en el proceso de la Independencia; entonces lo que queremos es romper con una tradición elitista de la visión de la Independencia e incorporar al pueblo en el análisis del proceso. ${ }^{343}$

En esta línea, el ministro de Cultura, Ramiro Noriega, señalaba que "un evento de esta magnitud no debe ser visto como una reunión intelectual de las élites, 'este criterio que lo he oído mucho' evita que el ciudadano común, desde lo popular, pueda acceder a la reflexión y al análisis de su propia historia". ${ }^{344}$

En cambio, quien sí introdujo algunos matices a la cuestión fue Paz y Miño. Más allá de haberse visto estrechamente involucrado en la organización de los festejos bicentenarios y de haber respaldado el mencionado evento académico "en el que participaron historiadores nacionales y extranjeros, además de maestros de historia”, el historiador objetó que "en el cronograma de esa entidad" faltó "trabajar en el impulso de la investigación de las historias locales, el involucramiento de sectores tradicionalmente marginados, como la Amazonía, para reforzar la identidad nacional". 345

Finalmente y en las antípodas de aquellos eventos, la Unión Nacional de Educadores -el sindicato docente más importante de Ecuador de impronta marxistaleninista- y la Federación de Estudiantes Universitarios del Ecuador, ambas organizaciones nucleadas en un Frente Popular opositor al gobierno "de derecha de

\footnotetext{
343 Disponible en: http://congresoindependencias.blogspot.com.ar/2009_07_01_archive.html

344 Disponible en: http://www.reporterodelahistoria.com/2009/07/la-historia-tiene-su-espacio-de.html

345 El Universo, 9 de agosto de 2009. Disponible en: https://www.eluniverso.com/2009/08/09/1/1355/ bicentenario-enciende.html
} 
Rafael Correa y Alianza Pais",346 llevaron a cabo el panel "Vigencia y significación histórica del 10 de agosto” en el Colegio Simón Bolívar de Quito.

Una crónica sobre la jornada subrayaba que "estas organizaciones populares" habían sido las únicas que le otorgaron "un toque diferente al festejo" en tanto reconocieron

en su justa medida el papel de los patriotas, pero también y sobre todo el de los pueblos de la antigua Real Audiencia de Quito, que generaron el ambiente previo a través de las sublevaciones indígenas, las revoluciones de las alcabalas y de los estancos, y que protagonizaron la lucha que siguió al 10 de Agosto, es decir, las luchas emancipadoras junto a Bolívar y Sucre. Luchas que continuaron luego de la independencia, por una inconformidad reflejada en el famoso graffiti que se pintó en las paredes de Quito, luego de la batalla del 24 de mayo: "Último día del despotismo y primero de lo mismo". ${ }^{347}$

Críticas a la historia liberal, denuncia de continuidad de la opresión imperial y reivindicación de la gesta popular fueron, así, los pilares de la narrativa elaborada por algunos movimientos sociales opositores al gobierno durante un bicentenario de "independencia" que, más allá del clima de fiesta que el Poder Ejecutivo se había propuesto impulsar, devino, a su vez, escenario de combate al condensar, reactualizar y reforzar las tensiones político-ideológicas que, en ese entonces, atravesaban al Ecuador de la RC.

\section{III. “Oda a los ganados y a las mieses". Las polémicas en Argentina}

\footnotetext{
346 En su blog, afirman: "Estamos combatiendo al gobierno de derecha de Rafael Correa y Alianza Pais que con su política atrasada, reaccionaria elitisa la educación universitaria, al imponer la mueva (sic) Ley Orgánica de Educación Superior (LOES). Eliminando las conquistas estudiantiles que las conseguimos con la fuerza de nuestra organización y las movilizaciones masivas de los universitarios del país; el libre ingreso, la gratuidad, la autonomía, el cogobierno, pretendiendo con ello pretender silenciar al movimiento estudiantil universitario, absurdamente formar profesionales "técnicos" desconociendo como es su practica la realidad ecuatoriana y trasplantando vergonzosamente modelos de otros países". Disponible en: http://feuenacional.blogspot.com
}

347 Voltaire.net.org, 24 de agosto de 2009. Disponible en: https://www.voltairenet.org/article161778.html 
"Un verdadero papelón doméstico, con ribetes de sainete criollo" fue la descripción que hizo un cronista de lo sucedido en las vísperas del festejo bicentenario de la revolución rioplatense. 348 Es que, separadamente de los actos y puestas en escena planificadas por el Poder Ejecutivo nacional, el gobierno opositor de la ciudad de Buenos Aires había proyectado su propia agenda conmemorativa, cuyo hito principal sería la reapertura del Teatro Colón -cerrado durante más de tres años por refaccionesdurante la noche del 24 de mayo.

Además de haber sido invitadas figuras como el entonces vicepresidente argentino, Julio Cobos, gobernadores opositores como Mario Das Neves y Hermes Binner, el ex presidente Fernando de la Rúa, los titulares de las principales entidades agropecuarias, el primer mandatario uruguayo, José Mujica, e incluso personajes mediáticos como el actor y empresario mediático Ricardo Fort, también se esperaba la asistencia de Fernández de Kirchner, quien -pese a las diferencias políticas- compartiría el palco principal con el entonces jefe de gobierno, Mauricio Macri.

Sin embargo, días antes del esperado acontecimiento, una ruidosa polémica estallaba entre la primera mandataria y el líder del Pro, cuando este último protestó, en el marco de una conferencia de prensa, que "iba a tener que sentarse al lado de Néstor Kirchner si la Presidenta decidía ir con su esposo", a quien acusaba "de haber impulsado la causa por espionaje en la que fue procesado".349

Con una carta escrita a mano y dirigida a Macri, Fernández de Kirchner cancelaba su participación en la gala en cuestión debido a la "increíble cataratas de agravios" que éste último había "proferido durante la última semana, llegando (...) a manifestaciones públicas descalificatorias de índole personal", todo lo cual habría marcado "un límite" que la mandataria no estaba "dispuesta a cruzar". A continuación, la misma señalaba

\footnotetext{
348 La Nueva, 23 de mayo de 2010. Disponible en: https://www.lanueva.com/nota/2010-5-23-9-0-0-elbicentenario-de-la-discordia

349 La Nación, 21 de mayo de 2010. Disponible en: https://www.lanacion.com.ar/politica/una-peleapolitica-opaca-el-festejo-del-bicentenario-nid1267086
} 
que la "política no puede, ni debe ser, una mera ceremonia de cinismo e hipocresía" y le deseaba, finalmente, un festejo "tranquilo y sin presencias molestas". 350

En lo que fue calificado como un verdadero "duelo" o "batalla" epistolar, el jefe de gobierno porteño replicó, de manera inmediata, con otra misiva en donde lamentaba "profundamente" aquella decisión debido a que esa noche era "una fecha histórica que" representaba "para todos los argentinos la voluntad y la esperanza de un mejor futuro que soñaron los héroes de la Revolución de Mayo". ${ }^{351}$ Asimismo, invitaba a Fernández de Kirchner a "reflexionar y reconsiderar su posición por el bien de todo nuestro pueblo" en tanto eso era "lo que los argentinos" necesitaban "de sus líderes" en aquel particular momento histórico. ${ }^{352}$

Lo cierto es que, más allá de las declaraciones a favor de la unidad por parte de estas dos fuerzas políticas, el enredo en torno a la reinauguración del histórico teatro porteño, que sucedió sin la presencia de la primera mandataria ni de dirigentes oficialistas, exacerbó el enfrentamiento entre el gobierno central y el de la ciudad de Buenos Aires. En efecto, no fue azaroso que la velada culminara con Macri y el entonces nuevo rival político del kirchnerismo, Julio Cobos, desplegando, desde el palco que compartían, una bandera argentina.

Ahora bien y pese a que este episodio acaparó una parte considerable de la atención en los días previos al aniversario patrio, un abanico de movilizaciones, marchas y protestas sociales, así como de debates y declaraciones provenientes del ámbito intelectual también contribuyeron a la reactualización de ciertas controversias y desacuerdos que rodearon a la celebración bicentenaria.

Con una serie de eventos y concentraciones, las entidades agropecuarias fueron algunos de los actores que celebraron de forma separada los doscientos de Mayo:

Locros en los viejos piquetes del 2008, desfiles de tractores, tranqueras embanderadas y la participación de algunos integrantes de la Mesa de Enlace en el

\footnotetext{
350 Perfil, 21 de mayo de 2010. Disponible en: https://www.perfil.com/noticias/politica/cristina-macripapelon-bicentenario-0520-0046.phtml

351 El Cronista, 20 de mayo de 2016. Disponible en: https://www.cronista.com/economia/Dueloepistolar-Cristina-desairo-la-invitacion-al-Colon-y-Macri-la-llamo-a-reflexionar-20100520-0154.html

352 La Nación, 21 de mayo de 2010. Disponible en: https://www.lanacion.com.ar/politica/una-peleapolitica-opaca-el-festejo-del-bicentenario-nid1267086
} 
Tedeum de la catedral metropolitana serán parte de una despareja movida agropecuaria. Los líderes de las entidades no coincidirán en una actividad, aunque sí lo harán sus representados en muchos de los puntos de las rutas que los albergaron dos años atrás, durante el conflicto por las retenciones móviles. ${ }^{353}$

Un ejemplo de ello fue el acto paralelo que tuvo lugar el 23 de mayo en la provincia de Entre Ríos organizado por la Federación Agraria Argentina, en donde el dirigente rural, Alfredo de Angeli, explicó que el mismo tenía como "fin principal (...) honrar a la Patria y refundar la República en vísperas del Bicentenario de la Nación Argentina". De igual modo, la concentración en la Ruta 14 sería aprovechada para "reclamar por el maltrato (...) [del] Gobierno hacia el campo y hacia los pequeños y medianos productores que fueron arrasados por esta nefasta política agropecuaria”. ${ }^{354}$

Por otro lado, la organización patronal Confederaciones Rurales Argentinas (CRA) emitía un comunicado en el que convocaba "a los hombres y mujeres del campo" a unirse "en el festejo" y "a conmemorar con orgullo nuestra identidad", a la vez que invitaba a renovar "la convicción de ser libres de gobiernos opresores".355

En esta línea, el entonces presidente de la Sociedad Rural Argentina, Hugo Biolcati, se pronunciaba públicamente afirmando que el 25 de mayo era una fecha "para reflexionar y para resaltar la memoria de quienes en 1810 se manifestaron por la libertad que 200 años después seguimos pidiendo: libertad de expresión, libertad para trabajar y libertad para comerciar los bienes que producimos". 356

De modo que el aniversario patrio resultó también una ocasión favorable para que las entidades agropecuarias, que dos años atrás habían liderado la extensa protesta contra la resolución 125, renovaran sus reclamos hacia el gobierno nacional y sus políticas de naturaleza “opresora".

\footnotetext{
${ }^{353}$ Clarín, 25 de mayo de 2010. Disponible en: https://www.clarin.com/ediciones-anteriores/campocelebra-manera-actos-movilizaciones_0_S1mNuS8Ratg.html

${ }^{354}$ La Política Online, 6 de mayo de 2010. Disponible en: https://www.lapoliticaonline.com/nota/ nota-65358/

355 Comunicado de CRA en ocasión del 25 de mayo de 2010. Disponible en: http:// panoramaruralahora.blogspot.com/2010/05/comunicado-de-cra-sobre-el-25-de-mayo.html
}

356 Clarín, 25 de mayo de 2010. Disponible en: https://www.clarin.com/ediciones-anteriores/campocelebra-manera-actos-movilizaciones_0_S1mNuS8Ratg.html 
Por otra parte, quienes también aprovecharon el carácter excepcional de la efeméride para visibilizar y presentar al Poder Ejecutivo sus "históricas demandas" fueron las comunidades indígenas, quienes -bajo la consigna "Caminando por la verdad, hacia un Estado plurinacional"- marcharon desde Jujuy, Misiones, Mendoza y Neuquén hacia la ciudad de Buenos Aires, donde, además de realizar un acto frente a la Casa Rosada, lograrían que un grupo de sus delegados fuera recibido por Fernández de Kirchner.

Respecto a lo discutido en la reunión, un representante de la Confederación Mapuche explicó que la mandataria

\begin{abstract}
Propuso una agenda de trabajo para la primera quincena de junio. Dijo que está de acuerdo en muchos puntos, y en otros para nada. Suponemos que no comparte nuestro rechazo a la minería, las petroleras y empresas que saquean y contaminan nuestros territorios, no lo dijo pero lo dio a entender (...) Nos hubiera gustado respuestas claras a nuestras demandas, pero sabemos que al Estado les cuesta entender nuestra realidad, aunque tiene claro que estamos organizados y no bajaremos las demandas. ${ }^{357}$
\end{abstract}

Luego del encuentro, tuvo lugar un acto en donde se leyeron las medidas tomadas por el Poder Ejecutivo,358 tras lo cual Fernández de Kirchner pronunció un breve discurso en el que no se "habló de reparación histórica ni reconoció el genocidio indígena, por el contrario planteó que la discriminación la sufren muchos sectores". 359 Si bien, para algunos de sus protagonistas, se había tratado de un "hecho histórico" ya que "por primera vez la presidenta de la Argentina” los recibía personalmente, 360 otros, en cambio, se mostraron críticos y decepcionados con las medidas y el discurso presidencial:

\footnotetext{
357 Página 12, 21 de mayo de 2010. Disponible en: https://www.pagina12.com.ar/diario/elpais/ 1-146102-2010-05-21.html

358 Respecto a las mismas, véase: http://archivo.argentina.indymedia.org/news/2010/05/733803.php

359 Crónica publicada en Red Agroforestal Chaco Argentina. Por otro lado, véase también el discurso pronunciado en Buenos Aires por Cristina Fernández de Kirchner el 20 de mayo de 2010. Disponibles en: http://redaf.org.ar/tras-multitudinaria-marcha-sin-reparacion-historica-en-el-bicentenario/
}

360 Véanse los testimonios recopilados por la Red Agroforestal Chaco Argentina. Disponibles en: http:// redaf.org.ar/tras-multitudinaria-marcha-sin-reparacion-historica-en-el-bicentenario/ 
No me gustó el discurso de la presidenta: los negros africanos y los pueblos indígenas pusimos los muertos en los procesos de emancipación así que yo como mínimo esperaba que diga que nos iba a devolver los territorios. No podemos pasar otros 200 años de colonialismo interno como los pasamos. La expectativa está en la lucha y en la fuerza organizada de nuestros pueblos $(\ldots)^{361}$

De igual manera, se cuestionó el modo en que fueron recibidos, así como la cantidad de tiempo que la entonces mandataria les había dispensado:

Estuvimos esperando 3 horas y media, con lluvia, cansados. Me parece que tendría que haber hablado un poco más. Los empresarios cuando vienen a reunirse con la presidenta no necesitan esperar nada, bajan de sus autos, con sus escoltas, y nosotros tenemos que esperar. Lamentablemente vamos a tener que seguir esperando. ${ }^{362}$

Así pues, la conclusión a la que muchos de ellos habían llegado era que:

este Gobierno no está a la altura de las circunstancias en cuanto a reparación histórica de los pueblos indígenas. Tenemos claro de que solamente el autogobierno nos va a devolver la dignidad. La reparación va a venir más que nada de la mano de la lucha y no de los que nos da el Gobierno. ${ }^{363}$

Los gestos y la retórica de carácter integracionista desplegados durante la celebración patria eran, de esta forma, impugnados por -al menos- un sector de los movimientos indígenas, el cual continuaba demandando que el reconocimiento simbólico fuera acompañado de una serie de reparaciones históricas de orden material asociadas, principalmente, a la redistribución de recursos.

Mientras que el Poder Ejecutivo nacional y el gobierno opositor de la ciudad de Buenos Aires rivalizaban a través de cartas o declaraciones públicas, las entidades agropecuarias reclamaban políticas menos asfixiantes y las comunidades indígenas marchaban y se manifestaban en el centro de la política argentina, el bicentenario de la

\footnotetext{
361 Ibídem.

362 Ibídem.

363 Ibídem.
} 
Revolución de Mayo también se convertía en objeto de atención y discusión entre varios académicos, ensayistas e intelectuales que se lanzaron a compartir sus perspectivas interpretativas de la efeméride en cuestión, así como disputar los sentidos en torno a ésta, principalmente, a través de los medios masivos de comunicación. 364

De modo que si bien, para algunos académicos, una característica de la celebración bicentenaria argentina habría sido "la casi inexistente profundidad histórica de las diversas intervenciones públicas" (Lesgart, 2010: 125), es posible identificar algunos cruces o discusiones de naturaleza política y, en menor medida, historiográfica, los cuales se vieron estrechamente vinculados a los antagonismos ideológicos que rodearon al aniversario patrio.

En este sentido, cabe recordar que el principal rasgo de la polémica surgida en las vísperas del mismo había sido la oposición centenario/bicentenario, la cual tempranamente recuperada por el propio Poder Ejecutivo-365 había servido a las necesidades del mismo al permitir ubicar en aquel pasado "antidemocrático y oligárquico" la génesis de los conflictos que entonces atravesaban a su gestión (Perochena, 2013).

Sin embargo, como recuerda Omar Acha, el gobierno kirchnerista no sería el único actor en apelar a la mencionada dicotomía:

Entre 2008 y 2010 las valoraciones de 1910 se reordenaron en el fragor transmitido por la política nacional. No es sorprendente que en ese andarivel las expresiones "históricas" de la intelectualidad kirchnerista, como la declaración del grupo Carta Abierta en cercanías del 25 de mayo de 2010, hiciera del centenario la contraposición de un presente abierto y pleno de oportunidades. En cambio, el

\footnotetext{
364 Para una reflexión en profundidad sobre las diferentes posturas que circularon al interior del mundo académico, así como las producciones editoriales surgidas a raíz de la efeméride, se sugiere la consulta de: Lesgart (2010), Rosemberg y Farías (2011); Rodríguez (2014).

365 Véase, a modo de ejemplo, el discurso pronunciado por Cristina Fernández de Kirchner en Iguazú durante los actos del 25 de mayo de 2009. Disponible en: https://www.cfkargentina.com/cristina-en-elacto-del-25-de-mayo-de-2009/
} 
entusiasmo con que se valoró positivamente 1910 (...) fue la bandera de quienes se situaron en la vereda opuesta del oficialismo (2011: 65). 366

Efectivamente, el 23 de mayo Carta Abierta -el grupo de intelectuales argentinos surgido en marzo de 2008 "en defensa del gobierno democrático amenazado por el conflicto suscitado por las patronales agropecuarias"_367 emitía una declaración en un diario de tirada nacional, en la cual sostenía:

Es en los hilos de lo pendiente (...) que pronunciamos el nombre de Argentina, en este Bicentenario.

No lo hacemos en la Argentina del Centenario, ese espejo virtual que los poderes actuales instalan en el lugar de Paraíso Perdido. En aquella Argentina un futuro que se imaginaba dorado, sobre la base de los ganados y las mieses, se proyectaba bajo la égida de un Estado excluyente, con las mayorías silenciadas políticamente y con un mundo popular asolado por la desdicha. El Centenario fue oropeles y visitantes extranjeros, tanto como estado de sitio y lucha callejera. República para pocos y Ley de Residencia. Un modelo de país agroexportador incapaz de proyectarse con autonomía del Imperio Británico (...) Jóvenes de clase alta incendiaron un circo plebeyo para que no alterase un paseo tradicional. Esas fogatas prepararon la Semana Trágica y los fusilamientos de la Patagonia, expresiones del odio oligárquico que se descargaría cada vez que el pueblo defendía sus derechos.

(...) No es nuestra tradición la que confunde "nación" con "raza" u origen geográfico ni la que reivindicó como causa nacional la aniquilación de pueblos originarios y de sus hombres y mujeres, la servidumbre y el despojo material y cultural $(\ldots)^{368}$

Frente a ese tipo de posicionamientos, se habían situado algunas intervenciones de figuras que, recogiendo ese mismo clivaje postulado por el kirchnerismo y ciertos

\footnotetext{
366 Cabe señalar que la exaltación del centenario como un período insigne de la historia argentina ya había sido esbozada en Mirando al Bicentenario. Reflexiones sobre el Bicentenario y memorabilia, publicado en el 2001 y coordinado por Rosendo Fraga y Ricardo Esteves. Asimismo, en el 2009 Natalio Botana, Rosendo Fraga y Luis Alberto Romero editaban un nuevo libro -titulado igual que el anterior- en donde, además de reeditar las crónicas de Georges Clemenceau sobre la Argentina del centenario, se disponían a reforzar justamente la idea de esta última como "una era gloriosa" (Acha, 2011: 65).

367 Véase la presentación del Espacio Carta Abierta. Disponible en: http://www.cartaabierta.org.ar/ index.php?option $=$ com_content\&view $=$ article \&id $=366 \&$ Itemid $=609$
}

368 Página 12, 23 de mayo de 2010. Disponible en: https://www.pagina12.com.ar/diario/elpais/ 1-146230-2010-05-23.html 
intelectuales afines al mismo, se propusieron invertir los elogios y las críticas asignados a los momentos históricos en cuestión. Así, el historiador Luis Alberto Romero recordaba que

En su Oda a los ganados y a las mieses, escrita en 1910, Leopoldo Lugones celebró la prosperidad argentina y la asoció con el gran crecimiento agropecuario. $\mathrm{Su}$ visión optimista sobre el pasado y el futuro argentino fue compartida por otros intelectuales y literatos, como Rubén Darío, y por notorios visitantes extranjeros, invitados a los magníficos festejos del Centenario de la revolución de Mayo. Les habría sorprendido saber que, cien años después, en la Argentina no se celebraría la prosperidad sino que se lamentaría la miseria y la decadencia. Que en lugar de certezas, solo habría dudas (2009: $\sin$ pp.)

Tiempo después, el mencionado académico volvía sobre esos argumentos y, al calor del bicentenario de Mayo, escribía en el suplemento cultural del Diario Clarín lo siguiente:

Ciudadano e historiador, quiero tratar de entender cómo se miraban en su espejo los argentinos de 1910 y compararlo con nuestras miradas de hoy. (...) Me temo que la comparación no ha de ser alentadora (...)

En 1910 el Estado estaba sólidamente afirmado, no había guerras interiores, las fronteras estaban definidas, y sus principales instituciones -el ejército, la escuela pública, el correo, entre otras- funcionaban eficientemente. A través de ellas el Estado pudo modelar un país pujante, impulsado por la inmigración, el crecimiento agrario y el comercio exterior. Era una época de confianza en la capacidad del Estado para dirigir y orientar todo, e inclusive para regular los conflictos (...)

La nacionalidad de 1910 era plural, tolerante y liberal, no excluía a nadie y ponía en primer término las ideas de ley y patria (...)

Hoy la sociedad argentina está fragmentada, segmentada y cada vez pesan menos las clases medias que supieron caracterizarla (...)

El resultado ha sido un Estado incapacitado de desarrollar políticas sostenidas. Para quienes lo gobiernan, es hoy como un automóvil sin acelerador, freno ni volante; una herramienta inservible y hasta peligrosa que como un televisor viejo, sólo funciona con golpes de autoridad, de resultados imprevisibles $(\ldots)^{369}$

\footnotetext{
${ }^{369}$ Intervención de Luis Alberto Romero en Revista Ñ del diario Clarín, 25 de abril de 2010. Disponible en: http://luisalbertoromero.com.ar/el-espejo-lejano-del-primer-centenario/
} 
En sintonía con el punto de vista de Romero, Marcos Novaro también intervenía públicamente para señalar que la "Argentina facciosa" del bicentenario no debía "ser con la que soñaron los hombres de Mayo, ni los del Centenario", al tiempo que resumía y explicaba el debate en cuestión de la siguiente manera:

Muchos de quienes proclaman en estos días inspirarse en el modelo económico vigente en 1910 y celebran los indudables logros que entonces el país podía mostrar a sus habitantes y al mundo, se han referido a la centuria transcurrida desde entonces como "los cien años perdidos". Desde el revisionismo (...) y el oficialismo se ha tendido a responder que el centenario no fue la maravilla que se cuenta, que dominaba entonces una pequeña oligarquía que había creado un país para pocos. Se recrea así una discusión que viene de largo: para los conservadores y liberales, Argentina perdió el rumbo cuando irrumpió el populismo, y abandonó las políticas de apertura al mundo, economía de mercado y control de la movilización política de las masas que hasta entonces tan buenos resultados habían dado; para los populistas en cambio, el problema fue la reacción conservadora y oligárquica ante el incontenible avance de los sectores populares en su aspiración de compartir los frutos del desarrollo ampliando sus derechos políticos y sociales. ${ }^{370}$

Seguidamente, el sociólogo entendía que una de las principales razones por las cuales al país no le había ido "todo lo bien que hubiera podido irle" había sido un factor que aquellas dos visiones desatendieron: la inestabilidad política, económica, social e institucional que habría marcado la vida del mismo durante el siglo XX, cuya persistencia en el presente era asociada, en el análisis de Novaro, a las políticas populistas promovidas por el gobierno de Fernández de Kirchner:

La inestabilidad que aún padecemos, y la cultura que la celebra, deben considerarse, en este sentido, como remanentes estériles de fenómenos en su origen asociados efectivamente a la juventud, la movilidad y la apertura al cambio que caracterizaron a la sociedad y la política argentinas hasta mediados del siglo pasado, y más en particular a la vía populista a través de la cual se canalizó entonces la democratización y la igualación social. Pero, en la imposibilidad de reeditarse esa asociación, la inestabilidad, y con ella el populismo, se han vuelto

370 La Política Online, 23 de mayo de 2010. Disponible en: https://www.lapoliticaonline.com/nota/ columna-406/ 
obstáculos más que alicientes o recursos para recuperar el dinamismo y la integración social perdidos. ${ }^{371}$

Si bien el debate en torno a 1910 y su confrontación con la Argentina contemporánea fue el rasgo protagonista de muchos de los discursos públicos que circularon en las vísperas del bicentenario, otras intervenciones giraron, en cambio, en torno a la valoración de los modos en que el Estado nacional había afrontado la efeméride en cuestión.

Tal fue el caso de Hilda Sábato, quien consideraba que el bicentenario había tenido "mucha bambolla pero poca sustancia". 372 "La palabra bicentenario parecía como una palabra mágica (...) porque se le pone a todo (...) [fue] como un adorno",373 criticaba la reconocida historiadora, al referirse, a modo de ejemplo, al fondo especial creado en diciembre del 2009 para garantizar el pago de los intereses de la deuda externa, el cual había sido denominado "Fondo del Bicentenario".

Respecto al festejo en sí mismo, Rodolfo Fogwill fue otra de las figuras que se había mostrado crítica con el gobierno nacional al opinar que estos habían sido "una semana de carnaval en la que reemplazaron la historia por la historia colectiva" y en la cual había prevalecido el "circo". "Seguramente la gente estuvo unida, pero cualquier domingo en el Rosedal (...) la gente corre y se sonríe”, afirmaba, a su vez, el renombrado escritor. ${ }^{374}$

En esta línea y conectándolo a la polémica con los festejos de 1910, la historiadora Marcela Ternavasio señalaba, incluso antes de que la celebración bicentenaria propiamente dicha tuviera lugar, que

Mientras que el centenario fue la celebración de un Estado que se festejaba a sí mismo en sus éxitos, y que tuvo una cantidad de iniciativas que, más allá de las

\footnotetext{
371 Ibídem.

372 BBC, 25 de mayo de 2010. Disponible en: https://www.bbc.com/mundo/america latina/ 2010/05/100525 0723 bicentenario_argentina identidad_cr.shtml

373 Entrevista radiofónica a Hilda Sábato, 21 de mayo de 2010. Disponible en: https:// radiouniversidad.wordpress.com/2010/05/21/los-historiadores-piden-valorar-el-bicentenario/

374 El Universal, 28 de agosto de 2010. Disponible en: http://archivo.eluniversal.com.mx/primera/ 35457.html
} 
críticas de que es objeto, fueron exitosas, ahora asistimos a una suerte de festival carnavalesco, con iniciativas fragmentadas, básicamente improvisadas, y sin un sentido que las englobe. 375

Por el contrario, para el escritor Mario O’Donnell, la celebración de los doscientos años de la revolución rioplatense se habría tratado de "una jornada histórica donde la gente participó masivamente porque (...) [buscó] reconocerse como nación”. ${ }^{376}$ En esta línea, el ensayista y filósofo Ricardo Forster elogiaba las acciones conmemorativas desplegadas por el Poder Ejecutivo al afirmar que

La ciudad se abrió y los cuerpos se movieron con libertad desprendiéndose de los miedos impuestos, de esos trazos de ficción mediática que apabullaron desde pantallas y rotativas la cotidianidad de los argentinos hasta construir la imagen de una sociedad en estado de guerra y de intemperie, asolada por la inseguridad y prisionera de una violencia autodestructiva que, siempre, asumía el rostro del oscuro habitante de esos arrabales transformados, gracias a las retóricas del amarillismo y el racismo, en las zonas del mal. Desde allí vinieron de a miles y miles desmintiendo (...) a quienes, desde el desdén y la más cruda violencia del lenguaje discriminador, no se cansaron de repetir que los mueve el clientelismo y el choripán (...)

Buenos Aires en una magnífica alquimia de ágora y carnaval, de imágenes monumentales desplegadas sin medir riesgos estéticos por la fuerza bruta de la invención artística y la inquieta interrogación por aquello del pasado que sigue insistiendo en el presente. Fue alegría compartida y conmoción ante los dolores y los horrores de nuestra historia, que también estuvieron allí, sin ocultamientos ni narraciones edulcoradas. 377

Al igual que en Ecuador, ciertos sectores de la izquierda opositora al gobierno de Fernández de Kirchner también se hicieron eco de estas polémicas y organizaron ciclos de charlas o escribieron editoriales, a través de los cuales dieron a conocer sus pareceres. Así, el sociólogo y dirigente del Partido de los Trabajadores Socialistas

\footnotetext{
375 Entrevista a Marcela Ternavasio, 5 de enero de 2010. Disponible en: https://journals.openedition.org/ nuevomundo/58253

376 Ibídem.

377 Página 12, 30 de mayo de 2010. Disponible en: https://www.pagina12.com.ar/diario/elpais/ 1-146644-2010-05-30.html
} 
(PTS), Christian Castillo, no solo se posicionaba en contra de las lecturas de "la derecha" que defendieron "el Estado de 1910", sino también del discurso oficial que exaltó la Argentina “popular” del bicentenario.

Sobre este último, Castillo insistía que, con el fin de proyectar esa imagen durante las celebraciones bicentenarias, el Poder Ejecutivo nacional había

intentado apropiarse de una serie de luchas y gestas protagonizadas por los trabajadores y el pueblo que van en un sentido muy distinto de lo que es su política $\mathrm{y}$ tiene, incluso, algunos aspectos particularmente perversos porque si ustedes siguieron los festejos (...) Habrán podido notar cómo uno de los ejes discursivos (...) fue la política que llamamos el operativo de reconciliación con las Fuerzas Armadas (...) qué más perverso que montar paneles con la lucha de las Madres, las Abuelas de la plaza de Mayo, reivindicar la gesta de lucha contra la dictadura al servicio de una política de relegitimación del brazo armado de la burguesía (...) se sacó a desfilar nuevamente a las fuerzas represivas (...) a la policía del gatillo fácil, a los que participan de la ocupación actual de Haití junto a las tropas norteamericanas (...) para relegitimar su papel y en el futuro tenerlas disponibles si hay luchas populares $(\ldots)^{378}$

Otros, como la organización política Razón y Revolución, eligieron como blanco de sus críticas la rivalidad - nuevamente avivada en las cercanías del aniversario patrioentre los "historiadores académicos" 379 y el "revisionismo K", para condenar, en última instancia, a ambos actores como funcionales al sostenimiento del statu quo:

Una vez más, los académicos están ofendidos. Otra vez, les han quitado protagonismo (...) simples divulgadores les han robado la conciencia de las masas $(\ldots)$

\footnotetext{
${ }^{378}$ Intervención de Christian Castillo en el ciclo de charlas organizado por el Instituto del Pensamiento Socialista Karl Marx. Disponible en: https://www.dailymotion.com/video/xdru5j\#

379 Cabe recordar que, en las vísperas del bicentenario de Mayo, un grupo de historiadores académicos pertenecientes a distintas universidades del país conformaron un colectivo llamado "Los historiadores y el Bicentenario" con el objetivo de "salir al espacio público e intentar divulgar las revisiones historiográficas que se (...) [habían] promovido en los últimos años" en torno a lo acontecido en mayo de 1810, lo cual derivó en la publicación de la obra titulada Dos siglos después. Los caminos de la revolución. Textos para el debate.

Si bien la página web oficial de "Los historiadores y el Bicentenario" ya no se encuentra disponible, se sugiere ver la entrevista realizada a la historiadora Marcela Ternavasio, donde ésta explica los motivos que condujeron a la conformación del mencionado grupo. Disponible en: https://journals.openedition.org/ nuevomundo/58253
} 
Quienes dominan los claustros académicos llegaron a la Universidad a partir de la derrota de la oleada revolucionaria, en la década de 1980. De revolucionarios se convirtieron en socialdemócratas y de allí, muy rápidamente, al liberalismo más ramplón. De Hobsbawm pasaron, sin escalas, a François Furet (...)

En un sentido profundo, academia y revisionismo no son otra cosa que dos caras de una misma moneda: dos barricadas del conservadurismo burgués que, acompañando al personal político, intentan sostener el orden vigente. Así como los defensores de la "nueva historia política" luego de la dictadura, el revisionismo K se puso en marcha cuando las brasas del Argentinazo aún quemaban, con el objetivo de canalizar el movimiento en el interior del sistema político republicano. Ambos pretenden, con su versión de la historia, desterrar a la Revolución al pasado. En este bicentenario, les corresponde a los obreros reconocer a los intelectuales que defienden sus mismos intereses de clase, reivindicando para sí, los métodos de los héroes de $1810 .{ }^{380}$

De modo que las controversias suscitadas al calor del bicentenario argentino dejaron en evidencia la existencia de un abanico relativamente amplio y heterogéneo de voces e intervenciones de carácter disidente, cuyos pareceres político-ideológicos e historiográficos antagónicos a la hora de entender el pasado pero, sobre todo, el presente nacional pusieron en jaque los intentos oficiales por matizar, durante la celebración bicentenaria, la partición del espacio socio-político que, desde el 2008, venía caracterizando la vida política y pública de la Argentina.

\section{IV. "Ni dinastías coronadas o uniformadas". Las polémicas en Venezuela}

Frente a la propuesta conmemorativa oficial organizada para el bicentenario de la Revolución del 19 de abril, una de las principales medidas tomadas por la oposición al gobierno de la Revolución Bolivariana -entonces agrupada en la Mesa de la Unidad Democrática y la Academia Nacional de Historia- consistió en la emisión de un

\footnotetext{
380 Razón y Revolución, editorial publicada en línea el 22 de agosto de 2015. Disponible en: http:// www.razonyrevolucion.org/contra-la-revolucion-los-historiadores-academicos-y-el-bicentenario/
} 
comunicado especial, el cual acusaba que la recordación y la celebración de aquella fecha patria estaban ocurriendo "en una Venezuela cuya libertad y democracia" se veían “amenazadas".381

Al hacer referencia a dicho pronunciamiento, un editorial señalaba que, a través del mismo, "los críticos de Chávez" pretendían manifestar que éste había traicionado "el legado del 'Libertador"”, además de denunciar que los festejos estaban orientados "a alimentar el ego del "caudillo militar". ${ }^{382}$ Asimismo, el escrito continuaba con lo siguiente:

$\mathrm{Su}$ tendencia es "imponer un orden político en el cual sólo exista un actor, el Estado, resumido en la voluntad de una persona, en contra de los intereses de la sociedad, apropiado de los medios de producción y con pleno dominio de los medios de la libertad de expresión y de la educación". 383

Además de la difusión de un comunicado, algunos sectores opositores organizaron un acto paralelo en conmemoración del bicentenario en la Plaza Brión, donde el coordinador del partido Primero Justicia, Julio Borges, alegó que "luego de 200 años", el país se encontraba "nuevamente bajo una oprobiosa dominación extranjera. El Presidente con su indignante sumisión al régimen de los Castro ha permitido que Venezuela haya sido invadida por otra nación: Cuba", sentenciaba Borges. ${ }^{384}$

Para el escritor Alberto Barrera Tyszka, el estrecho vínculo de Chávez con Fidel y Raúl Castro -especialmente evidenciado durante las celebraciones bicentenarias- habría respondido a otro factor. Es que, para el poeta y narrador de origen venezolano, el líder de la RB estaba "tratando de refundar, en las circunstancias del siglo XXI, la vieja dictadura militar latinoamericana del siglo XX", para lo cual necesitaba "una leyenda, como Fidel Castro". "Chávez tiene petróleo, pero no tiene leyenda", razón por la que se

\footnotetext{
381 Abc.es, 20 de abril de 2010. Disponible en: https://www.abc.es/20100419/internacional-iberoamerica/ bicentenario-venezuela-201004191833.html

382 Notimérica, 19 de abril de 2010. Disponible en: https://www.notimerica.com/politica/noticiavenezuela-presidentes-sudamericanos-izquierda-celebran-junto-chavez-200-anos-independenciavenezuela-20100419224132.html

383 Ibídem.

${ }^{384}$ Abc.es, 20 de abril de 2010. Disponible en: https://www.abc.es/20100419/internacional-iberoamerica/ bicentenario-venezuela-201004191833.html
} 
habría presentado, durante los actos conmemorativos, como el encargado de "cerrar las promesas de Bolívar". 385

A su vez, el autor calificó a estos últimos como "una celebración oficial más, otra ceremonia del poder (...) Pomposa y lejana" a partir de la cual se uniformó a la población y se intentó conseguir la "epopeya" que le faltaba al proyecto político de Chávez, ${ }^{386}$ todo lo cual habría ratificado que se encontraban "ante un Gobierno que se ha empeñado en reescribir la memoria del país. Más que cambiar las condiciones objetivas del presente, este Gobierno se ha dedicado a cambiar el pasado".387

Otra figura de la política nacional que también se pronunció en contra del entonces mandatario venezolano y el despliegue festivo organizado para la ocasión fue el ex presidente venezolano, Carlos Andrés Pérez, quien, en otro comunicado, señaló que no era "posible celebrar esta fecha patria cuando un régimen militarizado, autoritario y precomunista, encabezado por un oficial golpista y magnicida ha secuestrado el país ejerciendo un control total sobre todos los poderes del Estado". 388

Aunque más sutiles, las declaraciones de la cúpula eclesiástica también se enmarcaron en esa misma línea. En efecto, a principios del 2010, la Conferencia Episcopal Venezolana (CEV) publicaba la "Carta Pastoral sobre el Bicentenario de la Declaración de Independencia de la República”, en la cual argumentaba que

La transformación iniciada en 1998, fue el resultado de un profundo anhelo, definido como un proyecto inédito de "refundar" la República, , y por eso contó inicialmente con un gran respaldo popular; sin embargo, el mismo se ha venido concretando en un "proceso de cambio", primero de régimen, por un proceso constituyente y una nueva Constitución; luego de sistema, calificado ahora como revolucionario, de pretensión totalitaria, ya que intenta reestructurar tanto lo socioeconómico como lo político-institucional, lo jurídico-constitucional y lo éticocultural. Por estas razones, su ambición no sólo toca el tejido material y

\footnotetext{
385 Declaraciones de Alberto Barrera Tyszka recogidas por el diario Paraguay.com, 18 de abril de 2010. Disponible en: http://www.paraguay.com/internacionales/lideres-latinoamericanos-llegan-a-caracas-parala-celebracion-de-bicentenario-20607

386 Ibídem.

${ }^{387}$ Ibídem.

388 El Informador, 18 de abril de 2010. Disponible en: https://issuu.com/elinformador.com.ve/docs/ elinformador2010.04.18
} 
organizativo del cuerpo social, sino también, y sobre todo, afecta el fondo íntimo, espiritual, del alma nacional. Todo esto, en su ideario y realizaciones, no sólo se presta a grandes ambivalencias y ambigüedades, sino que contradice elementos fundamentales de una auténtica cultura democrática. ${ }^{389}$

En los días previos al 19 de abril, la CEV volvería a apuntar contra la RB poniendo el foco, esta vez, en el sesgo militarizado de los discursos y las prácticas conmemorativas desplegadas por el Poder Ejecutivo durante el aniversario patrio, sobre todo tras el anuncio del lanzamiento de los denominados "comandos juveniles de guerrilla comunicacional"; hecho que condujo al primer vicepresidente de la CEV y arzobispo de Mérida, Baltazar Porras, a señalar "que estar hablando de formar milicias" durante "un acontecimiento que marcó las puertas de la libertad y de la independencia" era "una perversión" que trataba "de llevar fuera de la verdad a los hechos".390

Es que, para la mencionada institución, el proceso independentista había consistido en una serie de acontecimientos

en los que brilló la civilidad. La autoridad de la inteligencia, el diálogo, la firmeza y el coraje no tuvieron que recurrir al poder de las armas o a la fuerza y a la violencia. La sensatez en el intercambio de ideas y propuestas respetó a los disidentes y propició el anhelo común de libertad, igualdad y fraternidad. ${ }^{391}$

Reforzando esa misma línea interpretativa, la intervención de la Universidad Central de Venezuela (UCV) en ocasión de los doscientos años del 19 de abril de 1810 mediante el acto denominado “Año Bicentenario Ucevista. 200 años de autonomía, independencia y libertad" resulta, asimismo, sugerente. En efecto, el objetivo de esta

\footnotetext{
389 Carta Pastoral sobre el Bicentenario de la Declaración de Independencia de la República. XCIII Asamblea Plenaria Ordinaria del Episcopado Venezolano. Disponible en: https:// entreamigosyfamiliacatolica.wordpress.com/2010/01/20/carta-pastoral-sobre-el-bicentenario-de-ladeclaracion-de-independencia-de-la-republica-xciii-asamblea-plenaria-ordinaria-del-episcopadovenezolano/\#more-2008

390 Vida Nueva Digital, 14 de mayo de 2010. Disponible en: https://www.vidanuevadigital.com/ 2010/05/14/el-bicentenario-de-venezuela-confronta-a-la-iglesia-con-el-modelo-oficial-de-chavez/

391 Carta Pastoral sobre el Bicentenario de la Declaración de Independencia de la República. XCIII Asamblea Plenaria Ordinaria del Episcopado Venezolano. Disponible en: https:// entreamigosyfamiliacatolica.wordpress.com/2010/01/20/carta-pastoral-sobre-el-bicentenario-de-ladeclaracion-de-independencia-de-la-republica-xciii-asamblea-plenaria-ordinaria-del-episcopadovenezolano/\#more-2008
} 
institución había sido organizar una serie "de actividades de orden académico y cultural, con la aspiración de ofrecer una propuesta distinta" que sirviera "como un primer aporte sólido y prospectivo para una nueva concepción" de la historia nacional republicana capaz de dejar "de lado el abordaje" que privilegiaba "el estamento militarista".392

Las palabras pronunciadas por la rectora, Cecilia García-Arocha, durante el agitado acto de inauguración, ${ }^{393}$ buscaron reivindicar nuevamente el "carácter civil" de la gesta emancipadora, al igual que destacar una serie de principios y valores que, para dicha institución, había estado -y debía continuar estándolo- en el centro de un proyecto democrático:

De este movimiento emancipador se hizo partícipe la Universidad, teniendo como referencia los principios de la Revolución Francesa y aquellos de la Independencia de las trece colonias de la América del Norte, orientado por un conjunto de derechos naturales e imprescriptibles del nuevo ciudadano como lo son: la libertad, la seguridad jurídica, la propiedad, la separación de poderes y la igualdad de todos los ciudadanos ante la ley y la justicia. (...)

Quiere la UCV rescatar y a la vez ampliar significativamente el conocimiento acerca del carácter civil de la fecha bicentenaria patria, enfatizando la participación de los universitarios, particularmente de los ucevistas en la consecución de la independencia y la construcción de la libertad y la democracia a lo largo de 200 años de existencia republicana $(\ldots)^{394}$

Así pues, las principales voces disidentes que circularon durante el aniversario patrio del 19 de abril censuraron los discursos y las prácticas conmemorativas desplegadas por el Poder Ejecutivo en tanto no habrían hecho otra cosa que profundizar la aducida naturaleza autoritaria, castrense y falaz del "régimen" chavista. Estos alegatos críticos, lejos de apaciguarse tras la celebración propiamente dicha, se vieron recrudecidos cuando Chávez anunció -meses después como parte del ciclo

\footnotetext{
392 Discurso pronunciado por Cecilia García-Arocha en Caracas, 21 de abril de 2010. Disponible en: https://vimeo.com/11219249

${ }^{393}$ Un grupo de aproximadamente veinte estudiantes alineados al chavismo irrumpió en el Aula Magna de la universidad cuando la rectora tomaba la palabra para dar inicio al acto, debiéndose suspender por un momento la inauguración del mismo en medio de cánticos a favor y en contra del gobierno.

394 Ibídem.
} 
conmemorativo del bicentenario de "independencia"- la exhumación de los restos de Bolívar a fin de esclarecer las causas de su muerte. ${ }^{395}$

De esta forma, la oposición acusaría, una vez más, al Poder Ejecutivo venezolano de encabezar una "maniobra" que -disfrazada "con toda una parafernalia científica digna de la serie estadounidense CSI"-396 pretendía "desafiar la Historia oficial de Simón Bolívar", ${ }^{397}$ así como propiciar un "revisionismo con fines políticos" a fin de “desviar la atención pública de serios problemas como la inseguridad, el desabastecimiento de alimentos, y los escándalos por la presunta corrupción gubernamental".398

Si bien hubo intelectuales -como el periodista, historiador y escritor Manuel Caballero- que prefirieron no explayarse sobre "semejante payasada", 399 otros indignados con la decisión presidencial- eligieron pronunciarse públicamente, como sucedió con el reconocido historiador y miembro de la Academia Nacional de Historia de Venezuela, Elías Pino Iturrieta, quien sostuvo que el acto en cuestión constituyó

un avance peligrosísimo de la reescritura de la historia de Venezuela y de América Latina que hace Chávez. Él está mostrando al pueblo que es dueño de una de las piezas fundamentales de la memoria: lo que queda físicamente de Simón Bolívar (...). Un acto de esa naturaleza debe tener una justificación, pero aquí la única es el capricho de Chávez. 400

\footnotetext{
395 Es preciso recordar que, según Chávez, Bolívar no había muerto por tuberculosis, sino que éste habría sido envenenado con arsénico por la "oligarquía colombiana" al mando de Santander.

Por otro lado, cabe recobrar las palabras proferidas por el líder de la RB al ser exhumados los restos del Libertador: "Confieso que hemos llorado, hemos jurado. Les digo: tiene que ser Bolivar ese esqueleto glorioso, pues puede sentirse su llamarada. Dios mio (sic)". Disponible en: https://twitter.com/ chavezcandanga/status/18662723365
}

396 Urgente 24, 1 de octubre de 2010. Disponible en: https://archivo.urgente24.com/77560-delirio-delbicentenario-reescribir-la-historia

${ }^{397}$ El Mundo, 17 de julio de 2010. Disponible en: https://www.elmundo.es/america/2010/07/16/ venezuela/1279300516.html

398 Ibídem.

399 BBC Mundo, 16 de julio de 2010. Disponible en: https://www.bbc.com/mundo/america latina/ 2010/07/100716 exhuman restos bolivar_venezuela chavez $1 \mathrm{r}$

400 Urgente 24, 1 de octubre de 2010. Disponible en: https://archivo.urgente24.com/77560-delirio-delbicentenario-reescribir-la-historia 
Estas críticas y acusaciones que afloraron en julio de 2010 quedarían sintetizadas en el acalorado cruce de posiciones políticas e historiográficas que tuvo lugar casi un año después durante dos emisiones televisivas programadas especialmente para la conmemoración del bicentenario de la Declaración de Independencia. Apoyándose en su capital simbólico y cultural, Pino Iturrieta volvía a contestar e impugnar la lectura del pasado independentista delineada por el Poder Ejecutivo venezolano cuando el 5 de julio de 2011 participó de una entrevista emitida por la cadena opositora Globovisión, en la que declaró que

El movimiento de 1811 que tiene origen en el movimiento del 19 de abril de 1810 es protagonizado exclusivamente o casi exclusivamente por los propietarios blancos criollos. Todos son blancos criollos, o civiles o eclesiásticos, muy pocos militares y un solo pardo (...) De manera que la representación abrumadora pertenece a la aristocracia venezolana (...) la posibilidad de entender el proceso de independencia como una obra de la sociedad venezolana es exagerado. ${ }^{401}$

Al ser consultado por la entrevistadora por qué, entonces, "pareciera haber prosperado" una intención por "comparar la sociedad de 1811" con la actual, el historiador venezolano explicaba, de manera tajante, que se trataba de una operación en absoluto original- que consistía en "manipular" la historia:

Es la búsqueda de imponerle (...) al pasado los valores y los intereses del presente pero los valores y los intereses del pasado evidentemente son distintos. Debo decir que no se trata (...) de una manipulación del régimen actual (...) Lo hizo Guzmán a partir de 1870, lo hace Gómez y después llega a su apogeo cuando López Contrera (...) funda las cívicas bolivarianas (... $)^{402}$

Sin embargo, para Pino Iturrieta, esta tendencia llegaba, durante las celebraciones bicentenarias, "a su clímax", poniendo en evidencia "la manipulación escandalosa" que hacía el gobierno de la historia:

\footnotetext{
${ }^{401}$ Intervención de Elias Pino Iturrieta acontecida el 5 de julio de 2011 en una entrevista televisiva emitida por Globovisión y recogida por el programa La Hojilla de la cadena oficialista Venezolana de Televisión. Disponible en: https://www.youtube.com/watch?v=H9PUgE1G70U 402 Ibídem.
} 
ahora, cuando se habla de socialismo y cuando al terminar la lectura del acta de la independencia, como vimos, se dice "Viva Guaicaipuro" cuando los indios no están presentes ni siquiera en la mente de los constituyentes de 1811, mucho menos la alternativa del socialismo, (...) uno ve cómo verdaderamente la manipulación es escandalosa (...) La ciudadanía hoy es un proyecto, todavía. En cuanto la ciudadanía es (...) el compromiso individual con el bien común para la convivencia republicana, no podemos decir que sea un fenómeno masivo y establecido. Lo que se plantea en el 11 con tanta vacilación sigue siendo un desafío todavía de la sociedad contemporánea porque ser ciudadano significa no ser necesariamente militante de un partido ni seguidor de un personalismo, sino entendimiento del bien común a través del derecho que yo tengo y la obligación que yo tengo de participar en su fábrica y eso todavía (...) no existe del todo (...)

Nos declaramos independientes (...) ahí comienza nuestra proceso de natalicio como sociedad (...) ¿y qué hacemos con la gente que no está representada aquí? ¿Qué hacemos con los pardos (...) los esclavos? El tema esclavitud no se toca (...) y no van a tocar la propiedad (...) uno de los principios fundamentales de la república de 1811 es la propiedad y en la propiedad no solamente se incluyen las cosas y las bestias, sino también los hombres $(\ldots)^{403}$

Quien salió al cruce de estas declaraciones fue el abogado, historiador, magistrado de la Corte Suprema y antiguo alumno de Pino Iturrieta, Carlos Escarrá Malavé, cuando -invitado aquel mismo día al programa oficialista La Hojilla transmitido por la cadena Venezolana de Televisión- se propuso explicitar los motivos que habrían estado detrás del enfoque interpretativo esbozado por Pino Iturrieta:

él es paecista (sic) y antichavista y yo soy bolivariano y chavista (...) ahora, lo que me preocupa es cuando una persona pierde las perspectivas en su propia ciencia. Él es historiador (...) él tiene que entender (...) [que] la historia está llena de causalidades (...) la historia no son hechos que se pegan (...) lo que él afirmó, por ejemplo, hacia atrás es negar a José Leonardo Chirinos, al negro Miguel, a Guaicaipuro (...) En la sociedad patriótica estaban incorporados y eso lo sabe Elías Pino, mujeres (...) los llamados pardos beneméritos (...) los llamados negros 
libertos (...) quieren crear una matriz (...) reivindicar el carácter civil de los hechos del 5 de julio de 1811.404

Lo que el miembro de la Academia Nacional de la Historia de Venezuela habría pretendido hacer -a ojos del conductor del programa, Mario Silva- era, entonces, "apartar a [los] militares" de la historia independentista, ${ }^{405}$ lo cual fue avalado por Escarrá, quien, además, se encargó de cuestionar el carácter imparcial y erudito de la narrativa histórica trazada por Pino Iturrieta:

claro, claro (...) en la plaza sí estaban los indios (...) los negros (...) los pardos (...) hubo una conducción de un sector pero también estaban incorporados [ellos] (...) nosotros no podemos entender los hechos [de la independencia] sin entender a Guaicaipuro y la resistencia indígena, sin entender todo lo que (...) fueron los afrodescendientes, nuestra madre patria África (...) ¿qué es lo que me preocupa? (...) yo no creo que Elías Pino desconozca esto $(\ldots)^{406}$

De modo que, durante el aniversario de la Declaración de Independencia, quedaban claramente sistematizados los principales rasgos de las dos tesis historiográficas que habían empezado a proliferar y tomar mayor impulso a medida que se acercaba el inicio del ciclo bicentenario venezolano. Si, para los sectores opositores, la gesta independentista se había tratado de un proceso histórico conducido por individuos civiles y letrados; para el oficialismo, la lucha -que aun continuaba- había sido militar y popular.

Por lo tanto, el eje de la polémica versaba, básicamente, sobre el sujeto revolucionario del movimiento independentista: para unos, había sido la élite aristocrática y letrada; para otros, el pueblo armado. Diferencias historiográficas que, en última instancia, servían a la legitimación o censura del presente venezolano.

En este sentido, no llama la atención que, nuevamente, la UCV organizara para el 5 de julio de 2011 un panel especial denominado "200 Años de la Independencia: El

\footnotetext{
404 Intervención de Carlos Escarrá Malavé acontecida el 5 de julio de 2011 en una entrevista televisiva del programa La Hojilla de la cadena Venezolana de Televisión. Disponible en: https://www.youtube.com/ watch? $v=$ H9PUgE $1 \mathrm{G} 70 \mathrm{U}$

405 Ibídem.

406 Ibídem.
} 
Bicentenario Civil”, el cual insistió nuevamente sobre la idea de que los protagonistas de la gesta emancipadora no habían provenido de las milicias, sino de las principales casas de estudio del país, así como sobre el hecho de que la historia consistía en una construcción permanente e ininterrumpida efectuada por los sectores civiles.

De esta manera, la rectora García-Arocha afirmaba en el acto de apertura:

esta fecha bicentenaria y la lectura detenida del acta de la independencia, nos recuerda que desde su nacimiento como nación la idea de libertad, el derecho a la felicidad, la división de poderes junto con la autonomía como nación soberana, han sido valores constantes en nuestro devenir histórico, contrarios a cierto pesimismo sociológico que nos quiere presentar como sociedad que espera pasiva redimirse mediante algún caudillo o tirano. (...)

Dada la magnitud de lo que hoy celebramos se han creado expectativas de diversa orientación, interpretaciones múltiples, que en ningún caso pueden convertir la gesta de ayer en elemento utilitario para intereses ajenos al verdadero significado y sentido de patria.

Sostenemos como ucevistas, proclives, sin duda, a la civilidad que el bicentenario no debe ser utilizado para legitimar un proyecto político o parcialidad alguna. Igualmente somos contrarios a reducir la gesta independentista, junto a sus símbolos como la firma del acta de la independencia, a una empresa épica con predominio militar, en la cual las voces de los legisladores, juristas, filósofos sean ahogadas por el ruido de los fusiles y el paso de los guerreros a caballos. (...)

En esta casa de reflexión (...) seguimos defendiendo los valores expresados en el acta de la independencia; libertad, soberanía, autonomía, derechos humanos, división de poderes, civilidad y sobre todo el derecho a ser nosotros mismos sin imposiciones, sin pensamientos absolutos con una vocación firme por la democracia y el pensamiento libre sin ataduras ni caudillos, ni dinastías coronadas o uniformadas. 407

Si bien menos resonante que estas dos posturas antagónicas, también circularon algunas críticas de izquierda al modo en que el Poder Ejecutivo venezolano presentó y entendió el bicentenario de independencia. Tal fue el caso del dirigente sindical y escritor, Santiago Arconada Rodríguez, quien -pese a haber ejercido funciones de asesoría en varias instancias del gobierno de la RB y formar parte del "proceso

407 Discurso pronunciado por Cecilia García-Arocha en Caracas, 6 de julio de 2011. Disponible en: http:// www.ucv.ve/en/organizacion/rectorado/discursos-pronunciados-por-la-rectora/julio-2011/ conmemoracion-del-bicentenario-de-la-independencia.html 
bolivariano"-, aseveró -en las vísperas del festejo del 5 de julio de 1811- que "con la política hacia el Bicentenario el gobierno bolivariano" estaba cometiendo "una flagrante claudicación en la tarea de deconstrucción de la cuerda de patrañas coloniales que la dominación construyó durante décadas como la historia oficial". ${ }^{408}$

Igualmente y luego de la celebración oficial, Arconada Rodríguez volvía a pronunciarse "contra el Bicentenario" por considerarlo "un operativo políticoepistemológico neocolonial” que había deslegitimado los levantamientos populares en contra del imperio español, a la vez que denunciaba el abandono, por parte del gobierno de la RB, de

ese curso crítico de deconstrucción de la falacia con la que nos han venido y nos siguen engañando (...) se retrocedió a posiciones verdaderamente ofensivas con el pasado, como inundar a Caracas con pendones de la Alcaldía del Municipio Libertador en los que, en alusión al 19 de abril de 1810, se leía (...) Doscientos años combatiendo imperios (...), haciendo que cualquiera se pudiera preguntar qué andaría haciendo Guaicaipuro en 1568, cuando Diego de Losada ordenó capturarlo vivo o muerto. Si no estaba combatiendo imperios (...) qué estaba haciendo, jugando metras? Pero si en verdad estaba combatiendo, al precio de su vida, al imperio español (...) por qué el Bicentenario lo borra?

Esa subalternización, cuando no invisibilización, de todo lo anterior a 1810, es el autogol político-epistemológico más grave que se ha infligido el proceso bolivariano y, lo que para mí es más importante, que no es un autogol que pasó sino que está pasando, está operando, está envenenando la posibilidad de que entendamos de dónde venimos y para dónde debiéramos ir (...)

Debe ser por eso que la derecha venezolana está tan tranquila con la conmemoración Bicentenaria (...) con su historia no nos metimos (...) La dejamos igualita, mentirosa, falaz. 409

Es así que, con excepción de este tipo de reclamos o inconformismos respecto al carácter indulgente, moderado y servicial que habrían tenido los discursos y las prácticas conmemorativas delineadas por el Poder Ejecutivo venezolano en ocasión de

\footnotetext{
408 Palabras de Santiago Arconada Rodríguez en la "Carta abierta al Presidente Hugo Chávez Frías", 2 de febrero de 2011. Disponible en: https://www.aporrea.org/ideologia/a116888.html 
las celebraciones bicentenarias, la mayoría de las críticas que circularon en aquel momento apuntaron principalmente contra el hecho de que la distorsionada lectura oficial del pasado independentista habría estado dirigida a legitimar un presente militarizado, oprobioso e indigno de una gesta libertaria guiada por un conjunto de principios muy distintos como la libertad, los derechos humanos, la división de poderes y la civilidad.

\section{V. "El Bicentenario se enciende". Terceras consideraciones provisorias}

Llegado a este punto, resulta indiscutible que la circulación de múltiples interpretaciones sobre el pasado nacional -exacerbada en tiempos de bicentenario- se fundó en la existencia de perspectivas, expectativas y valoraciones muy distintas respecto del presente de cada uno de estos países; en especial, del camino que estos debían dejar atrás a fin de convertirse, finalmente, en naciones más justas, inclusivas, prósperas y/o pujantes.

El contexto conmemorativo y la necesidad de discutir y desafiar ciertos aspectos de las narrativas históricas delineadas por los Poderes Ejecutivos y, por ende, sus intentos por disputar $\mathrm{y} / \mathrm{o}$ fortalecer su hegemonía condujeron, a su vez, a que las escisiones y los enfrentamientos fundacionales de cada nación se vieran reanimados y enlazados, de manera directa, a las contiendas del presente.

Esto supuso que, en casos como Bolivia y Venezuela, la línea de discusión versara, principalmente, sobre quién había constituido el sujeto revolucionario de la gesta emancipadora, lo cual implicaba debatir también en torno al carácter o la naturaleza de la revolución. Así pues, al momento de disputar en el ahora los sentidos y las representaciones de cada identidad nacional $-\mathrm{o}$, en términos más generales, la hegemonía cultural- no resultaba indiferente que el mito de origen se fundara en una revolución civil o militar/armada protagonizada por las élites criollas y letradas o por determinados sectores subalternos. 
Igualmente, otro de los ejes en disputa que afloró con particular fuerza durante las celebraciones bicentenarias tuvo que ver con el lugar de origen del movimiento independentista. Tanto en Ecuador como en Bolivia, esto se encontró ínsitamente relacionado con los conflictos regionales que históricamente marcaron la vida de estas dos naciones, los cuales se habían visto recrudecidos en las vísperas de los mencionados aniversarios patrios cuando los regionalismos guayaquileño y cruceño dieron el salto hacia el autonomismo (Burbano de Lara, 2012).

A diferencia del resto de los casos, en Argentina la controversia política e historiográfica central fue aquella que giró alrededor de la dicotomía entre liberalismo y populismo, reflejada o sintetizada según sus protagonistas, en dos signos históricos considerados excepcionales y opuestos a la vez: 1910 y 2010. Es que los efectos de la crisis del campo suscitada en el 2008 -que derivó en un agudo y prolongado enfrentamiento entre el Poder Ejecutivo nacional y vastos sectores de la sociedadtodavía persistían, lo cual explicaría por qué la atención no se situó en la reconstrucción que hizo el gobierno nacional del pasado independentista, sino en la contraposición valorativa de lo que cada parte estimaba que habían sido los modelos económicos, sociales y políticos vigentes durante el centenario y el bicentenario de la Revolución de Mayo.

Por último, en todos estos casos, las menos resonantes críticas opositoras provenientes de movimientos sociales, intelectuales, agrupaciones o partidos de izquierda pretendieron ubicarse por fuera de los enfrentamientos entre el oficialismo y la denominada oposición "de derecha", coincidiendo en señalar que los argumentos de unos y de otros, al constituir dos caras de una misma moneda, no hacían otra cosa que reproducir el statu quo burgués.

Con todo, aquel conjunto de querellas político-ideológicas y/o historiográficas sucedidas, en su mayoría, en los medios masivos de comunicación- constituyeron una herramienta clave al momento de reforzar y visibilizar las condenas o los elogios a los ordenamientos políticos y sociales vigentes en cada país. Por lo tanto, lo que estas discusiones pusieron de manifiesto fue que los bicentenarios de "independencia" habían sido concebidos - no solo por los Poderes Ejecutivos y sus adeptos, sino también por una parte importante de los sectores opositores a los mismos- como instancias 
fundamentales en el proceso de acumulación política; 410 es decir, como ocasiones particularmente propicias para, entre otras cosas, abogar por sus intereses particulares, a la vez que intentar presentarlos como el interés general de la nación.

410 En este punto, cabe recuperar las palabras de Friedrich Nietzsche en De la utilidad y los inconvenientes de la historia para la vida: "Llamésmolos los hombres históricos. El espectáculo del pasado los empuja hacia el futuro, inflama su coraje para continuar en la vida, enciende su esperanza de que lo que es justo puede todavía venir, de que la felicidad los espera al otro lado de la montaña hacia donde encaminan sus pasos. Estos hombre históricos creen que el sentido de la existencia se desvelará en el curso de un proceso y, por eso, tan solo miran hacia atrás para, a la luz del camino recorrido, comprender el presente y desear más ardientemente el futuro. No tienen idea de hasta qué punto, a pesar de todos sus conocimientos históricos, de hecho piensan y actúan de manera no-histórica o de que su misma actividad como historiadores está al servicio, no del puro conocimiento, sino de la vida." Disponible en: https://criticalatinoamericana.files.wordpress.com/2010/11/nietzsche-de-la-utilidad-y-losinconvenientes-de-la-historia.pdf 


\section{Capítulo V}

\section{Estado, política y nación en tiempos de bicentenarios}

Marc Bloch una vez afirmó que el objetivo de comparar "sociedades, a la vez, vecinas y contemporáneas" (1992 [1953]: 66), esto es, influidas entre ellas y procedentes de un origen -"al menos parcialmente"- común, no radicaba en buscar sus similitudes sugestivas sino, por el contrario, en identificar las divergencias entre casos. En este sentido, el objetivo último de la historia comparada consistía, según el historiador francés, en reconocer la originalidad de distintos fenómenos y sociedades cuyo punto de partida pareciera haber sido análogo, para lo cual desarticular las falsas similitudes y paralelismos entre ellos resultaba una tarea fundamental.

Si partimos de esas premisas, ciertamente las prácticas y los discursos conmemorativos desplegados durante los bicentenarios de "independencia" en Argentina, Bolivia, Ecuador y Venezuela se dirigieron, por un lado, a recrear el pasado, reactualizar el mito de origen, delinear sus filiaciones ideológicas y reconstruir la memoria histórica de cada nación en clave popular, épica y libertaria con fines tanto simbólico-identitarios como político-partidarios. Por el otro, las disputas por los símbolos y las representaciones que afrontaron esos gobiernos durante los festejos patrios se enmarcaron en los agudos conflictos político-ideológicos dominantes en estos países.

Ahora bien, los modos específicos en que los Poderes Ejecutivos decidieron proyectar, abordar y aprovechar las celebraciones patrias, es decir, el tipo de discursos, prácticas y representaciones allí desplegadas, habrían expresado formas distintas de hacer frente a aquellos procesos de reconfiguración simbólico-identitaria, así como de tratar con los diferentes intereses, problemáticas y demandas que, entonces, circulaban en cada sociedad. ¿En qué medida las elaboraciones que hicieron del pasado posibilitan, entonces, arrojar luz sobre los particulares proyectos y anhelos políticos que esos 
gobiernos tenían en aquel momento histórico?, ¿qué ideas de Estado y nación se desprenden de esos planteamientos?, ¿cuáles son sus implicancias a la hora de pensar a la sociedad y/o el territorio en su conjunto? y, finalmente, ¿qué nos dice todo esto de las formas en que aquellas experiencias gubernamentales lidiaron con el problema más clásico y general vinculado a la posibilidad de que el Estado represente el interés general?

Este capítulo se propone, por lo tanto, responder a estos interrogantes volviendo, una vez más, sobre las maneras en que cada Poder Ejecutivo afrontó y esbozó sus celebraciones de los doscientos años de "independencia" con la certeza de que aún es posible extraer nuevas consideraciones que confieran un sentido analítico iluminador a estos fenómenos en cuestión y, en especial, a los valores, concepciones, aspiraciones e intereses políticos que los rodearon, al menos, en los instantes de los bicentenarios.

\section{I. ¿"Bolivia es una sola montaña"?}

Las intenciones del gobierno del MAS por refundar y democratizar el país, construir un auténtico Estado nacional y defender la integridad de la patria parecieran haberlo conducido, durante el inicio del "Bicentenario de los Pueblos 2009-2025", a sumergirse en el pasado a fin de rastrear, restaurar y reivindicar aquellas figuras, acontecimientos y tradiciones que posibilitaran traer al presente el mito, la utopía y el valor de los pueblos indígenas para, de esa manera, cuestionar los supuestos sobre los cuales se había sustentado a lo largo de dos siglos la identidad boliviana dominante.

Ahora bien, las celebraciones previstas para el 25 de mayo y el 16 de julio de 2009 no fueron idénticas ni en sus propósitos, discursos o escenificaciones. En el caso del bicentenario de la Revolución de Chuquisaca, el Poder Ejecutivo decidió trasladarse hacia las sierras andinas junto a organizaciones y movimientos campesinos e indígenas alineados al gobierno. La memoria histórica allí esbozada por el gobierno de la Revolución Democrática y Cultural $-\mathrm{y}$, en especial, por su líder- entendió a los 
acontecimientos de 1781 como los primeros gritos de libertad y los fundamentos de las luchas independentistas. A su vez, el protagonismo otorgado a la cultura popular andina, al igual que la reivindicación y visibilización del ámbito rural y del campesinado quechua y aymara en tanto piezas clave de la nación completaron sus rasgos más sobresalientes.

De esta manera, los discursos y las prácticas conmemorativas desplegadas en El Villar habilitaron la delimitación, defensa y reivindicación de un "nosotros" enunciado genéricamente como "pueblos originarios", el cual entrañó, sin embargo, una serie de exclusiones que fueron más allá de la clase política opositora representante, según la retórica oficial, del neoliberalismo y asociada, fundamentalmente, a la llamada Media Luna.

Es que ese deslizamiento -a la vez, geográfico, simbólico y discursivo- pareciera haber tenido otras connotaciones como, por ejemplo, el relego de los sectores mestizos urbanos, así como la postergación de los indígenas de las tierras bajas del país (orientales y sureñas), cada vez más numerosos debido a la creciente inmigración proveniente de las sierras que ha tenido lugar en Bolivia en los últimos años (Molina, 2008); los cuales, aunque "demográficamente minoritarios y tradicionalmente ‘invisibles' a la política nacional” (Stefanoni, 2011: 28), habían devenido actores centrales de la RDC en esas regiones (Molina, 2008; Stefanoni, 2011).

Por su parte, la celebración trazada para el bicentenario de la Primera Junta Tuitiva de Gobierno -si bien inaugurada, nuevamente, en el altiplano boliviano- apuntó a contrarrestar el perfil más reservado y restringido de las narrativas y puestas en escena desplegadas en El Villar al adquirir un progresivo carácter urbano, apelar -aunque de manera acotada- a espectáculos de la cultura de masas y, fundamentalmente, incorporar en los discursos sobre la memoria histórica de la nación otras figuras y episodios históricos, geografías y clases sociales que permitieran flexibilizar la afirmación andinista delineada casi dos meses atrás durante el bicentenario de la Revolución de Chuquisaca y, de esta forma, proyectar un festejo que estuviera en sintonía con ciertas consignas conmemorativas puestas en circulación por el propio Poder Ejecutivo.411

\footnotetext{
411 Como, por ejemplo, la de las monedas conmemorativas entregadas en El Villar que rezaban "Bolivia para Todos: Complementariedad, Consenso, Equilibrio, Identidad".
} 
Pero, entonces, ¿cómo interpretar ese sutil cambio en el modo de reconstruir y celebrar el pasado nacional? En primer lugar, es preciso señalar que la retirada hacia El Villar fue el corolario del agudo enfrentamiento que venía suscitándose desde el 2006 entre el Poder Ejecutivo nacional y la oposición, cuyo punto álgido lo habían constituido los violentos episodios de mayo y septiembre de 2008 .

Sin embargo y tras aquella celebración bicentenaria ocurrida a "puertas cerradas", el Poder Ejecutivo comenzó a esbozar, hacia julio de 2009, un discurso de unidad, más abarcador, con el fin de incluir la heterogeneidad de fuerzas sociales que formaban el núcleo duro del MAS; lo cual habría respondido no solo a las alianzas y afinidades políticas que en ese momento aquél mantenía con las autoridades del departamento de La Paz o a la creciente proximidad de las elecciones generales, sino también a su afán por conciliar un proyecto nacionalista clásico con una agenda comunitarista.

En efecto, el inicio del "Bicentenario de los Pueblos" pareciera haber cristalizado, antes que nada, un giro en la trama de representaciones étnicas, de clase y, en cierta medida, de género, el cual debe enmarcarse en aquella tentativa del gobierno del MAS por reconfigurar la nación bajo una matriz nacional-popular con una impronta marcadamente andina.

Si tenemos en cuenta que lo que se había propuesto impulsar era una revolución de naturaleza "democrática y cultural", la refundación del pasado nacional y los desplazamientos territoriales, narrativos y/o estéticos que esa operación conllevó, en ocasión de los dos festejos bicentenarios aquí analizados, se vuelven coherentes dentro de un proyecto político que, desde sus inicios en el poder, había declarado la necesidad de superar el "colonialismo interno" rompiendo con la sujeción de los grupos originarios a una ciudadanía de segunda clase.

Por consiguiente, no resulta llamativo que las representaciones de la bolivianidad propuestas por el Poder Ejecutivo boliviano durante los bicentenarios patrios provinieran mayoritariamente del altiplano andino, haciendo resonar la caracterización de la nación efectuada por un médico, intelectual, poeta y político sucreño llamado Jaime Mendoza Gonzáles (1874-1939), cuya vasta y diversa producción escrita fue la que contribuyó a forjar la idea de que los Andes constituían la espina dorsal del territorio nacional. 
De hecho, cabe recordar que, tras las celebraciones patrias en cuestión, la vicepresidencia comenzaría a dar forma a uno de los proyectos editoriales más ambiciosos de la historia del país: la Biblioteca del Bicentenario de Bolivia. ${ }^{412}$ En el marco del "Bicentenario de los pueblos 2009-2025", el gobierno del MAS se proponía, entonces, lanzar por etapas doscientas obras consideradas "fundamentales para la comprensión del pasado y presente del país", cuya lectura permitiría "a los bolivianos verse a sí mismos y figurar, de ese modo, el futuro de Bolivia". ${ }^{413}$

Entre ellas, el Comité Editorial encargado de la selección incluiría, en una misma edición, El factor geográfico en la nacionalidad boliviana (2016 [1925]) y El Macizo Boliviano (2016 [1935]), dos libros escritos por Mendoza durante una época de cambios paulatinos, aunque profundos y significativos en tanto pondrían en jaque el statu quo oligárquico liberal. ${ }^{414}$

En ese contexto de crisis, Mendoza -apelando a las tesis del determinismo geográfico finisecular pero también a nociones culturales y espirituales de la cosmovisión indígena de base andina-415 sistematizaría su doctrina geopolítica de la reintegración territorial y social. Para el pensador sucreño, lo que constituía "el núcleo básico de la nacionalidad boliviana, geográficamente hablando" era "el Macizo Boliviano" (2016 [1925]: 89), estableciendo, así, la premisa clave de su teoría centrada

\footnotetext{
412 Un antecedente de este proyecto fue la Biblioteca del Sesquicentenario, creada en 1975 en el marco de la dictadura de Hugo Bánzer, con el propósito de celebrar los 150 años de la independencia de Bolivia. Véase: http://www.la-razon.com/opinion/columnistas/Biblioteca-Sesquicentenario 0 1713428740.html

413 Véase: http://www.bbb.gob.bo/acerca-del-proyecto/

${ }^{414} \mathrm{La}$ aparición del multipartidismo en el sistema político local, el debilitamiento de la ideología liberal con su fuerte impronta racista, la conformación de un movimiento obrero fuerte, el surgimiento de una izquierda radical que exclamaba "tierras al indio, minas al estado", la creciente movilización indígena expresada en múltiples levantamientos y rebeliones, así como la derrota en la Guerra del Chaco y la emergencia del nacionalismo revolucionario parecían sentar las condiciones de posibilidad para los anhelos del citado intelectual: intentar (re)construir las bases de la identidad nacional, integrar al país y redimir al "indio".
}

415 Hacia finales del siglo XIX y principios del siglo XX, el determinismo geográfico -cuyas raíces se remontaban al mundo antiguo (Heródoto, Platón, Estrabón)- entraba en contacto con las tesis evolutivas de Darwin y Spencer, desembocando en el positivismo naturalista o ambientalismo. Uno de sus mayores exponentes sería el geógrafo alemán Friedrich Ratzel, cuyos trabajos -embebidos de darwinismo socialsuelen ubicarse en el origen de la Geopolítica. Puntualmente, la tesis central de la mencionada escuela geográfica afirma -partiendo de la aplicación del método empírico inductivo- que los fenómenos naturales y el medio ambiente poseen un papel determinante en la explicación de los procesos sociales, culturales y políticos (Chicharro Fernández, 1987; López Trigal, 2011).

Es preciso agregar, en este sentido, la influencia económica, militar e intelectual que ejercía Alemania durante el primer tercio del siglo XX en Bolivia (Bieber, 1994, 2000). 
en la idea de que la geografía de la altiplanicie había ejercido y continuaba ejerciendo una influencia "decisiva y profunda" sobre la historia y la sociedad boliviana (Amorebieta y Vera, 2019).

De modo que en un país profundamente despojado y flagelado como Bolivia, la figura del "gran Macizo Andino" le había permitido a Mendoza encontrar un elemento de épica y fortaleza, cuya función política no era dividir al país, sino precisamente evitar su desintegración al brindarle un núcleo fundamental capaz de mantener asida a la nación. Casi un siglo después, la dirigencia del MAS también encontraba en los Andes un elemento mítico y poderoso para su retórica y práctica de reafirmación indígena y de confrontación con los sectores autonomistas y poderes imperiales que, conforme a su opinión, amenazaban la -históricamente esquiva- unidad nacional.

Ahora bien, a diferencia de los viejos indigenismos como el esbozado por Mendoza, en el intento de reindianización encarado por el Poder Ejecutivo boliviano

la indianidad [irrumpiría] por abajo, como núcleo cohesionador de la identidad subalterna, de indígenas de carne y hueso (...) que cuestionan la inclusión abstracta y la exclusión concreta en la que aun se mantienen, en tanto siguen siendo, en gran medida, ciudadanos de segunda en su propio país (Stefanoni 2010: 10).

Con todo, la naturaleza paradójica de aquella narrativa pareciera resultar inequívoca: si -como afirmaba el pensador sucreño- "Bolivia (...) es una sola montaña" (2016 [1925]: 127), entonces ¿qué significaba aquella búsqueda -reeditada en la actualidad- por ampliar e integrar la nación? Al igual que antes, aquel empeño seguía siendo esencialmente concebido en términos materiales -económicos e infraestructurales-416 $\mathrm{y}$, en ocasiones, la reivindicación indígena -pretendidamente global- continuaba encontrándose ceñida a lo quechua y aymara, perdiéndose de vista el resto de las identidades subalternas no andinas, así como la existencia de identidades múltiples y superpuestas.

Por lo tanto y volviendo sobre los modos en que el Poder Ejecutivo boliviano reformuló la memoria histórica y la identidad de la nación durante el inicio del largo

416 Lo cual, en el caso del gobierno del MAS, vino acompañado de una serie de tensiones y polémicas, al interior del mismo, entre los defensores del "vivir bien" y los adalides de la vía "desarrollista" (Svampa, Stefanoni y Fornillo, 2010). 
tramo conmemorativo que culminaría en el bicentenario de la independencia propiamente dicho, es posible sostener que los discursos y las prácticas desplegadas por el oficialismo en mayo y julio de 2009 parecieran -al menos hasta aquel entonceshaber chocado frente al desafío histórico que este último -a pesar de todas las dificultades- se había propuesto enfrentar: zanjar la persistente fragmentación étnica y regional de Bolivia e intentar una auténtica construcción hegemónica a nivel nacional o, en otras palabras, una construcción transversal -a la vez, simbólica y material- de carácter realmente plurinacional.

$\mathrm{Si}$-tras la crisis social, política e institucional del 2008 que la dirigencia del MAS había calificado como un "empate catastrófico" (García Linera, 2008)-417 el objetivo era consolidar su control sobre el Estado y el territorio, disputar las representaciones dominantes de la nación constituía, ciertamente, una de las tantas labores necesarias, lo cual se tradujo -durante las oportunas conmemoraciones bicentenarias- en una tendencia por proclamar y defender una indianidad andina frente a la consecución de una retórica nacionalista.

Indiferentes a la posibilidad de transformar los bicentenarios "locales" en fiestas nacionales y a la acusación opositora de "dividir y dañar a los bolivianos", 418 el Poder Ejecutivo boliviano se inclinó, en mayor medida, por una afirmación particularista que entró en contradicción con sus intenciones por integrar la comunidad nacional y exhibirse a sí mismo como capaz de representar y proteger el interés general de la nación.

De cualquier modo, aquellas inclinaciones -ya atenuadas durante el 16 de julio de 2009- a reforzar ciertos particularismos étnicos, así como a agudizar las rencillas político-partidarias terminarían por disolverse en el marco del $184^{\circ}$ aniversario del Día

\footnotetext{
417 En palabras del vicepresidente: "El empate catastrófico es una etapa de la crisis de Estado (...) que se caracteriza por tres cosas: confrontación de dos proyectos políticos nacionales de país, dos horizontes de país con capacidad de movilización, de atracción y de seducción de fuerzas sociales; confrontación en el ámbito institucional -puede ser en el ámbito parlamentario y también en el social- de dos bloques sociales conformados con voluntad y ambición de poder, el bloque dominante y el social ascendente; y, en tercer lugar, una parálisis del mando estatal y la irresolución de la parálisis. Este empate puede durar semanas, meses, años; pero llega un momento en que tiene que producirse un desempate, una salida. La salida del empate catastrófico sería la tercera etapa de la crisis del Estado, que la vamos a denominar construcción hegemónica ascendente" (García Linera, 2008: 26).
}

418 Diario Crítico, sin fecha. Disponible en: http://www.diariocritico.com/noticia/152010/noticias/ bicentenario-en-actos-paralelos.html 
de la Independencia, es decir, tres semanas después de la celebración desplegada en La Paz. En efecto y a tan solo cinco meses de las elecciones presidenciales y parlamentarias, aquella fue la ocasión elegida por Morales para volver a pisar la capital constitucional -luego de dos años sin concurrir a la misma- y aseverar que "el mejor homenaje" que podían "hacer desde la Casa de la Libertad" era "respetar las diferencias, [los] (...) colores de partidos" y juntarse "para servir mejor al pueblo boliviano". 419

No obstante ello, es posible sostener que esa vuelta conciliadora a Sucre no fue representativa de los modos en que el Poder Ejecutivo boliviano decidió posicionarse frente al inicio de las conmemoraciones bicentenarias y la oportunidad que éstas ofrecieron al momento de disputar los sentidos de la nación. En un principio, la propuesta oficial se inclinó hacia la partición de la comunidad política frente a la posibilidad de delinear una representación unitaria de la misma capaz de morigerar los conflictos políticos y sociales que atravesaban a la Bolivia de entonces.

Solo paulatinamente esos discursos y puestas en escena oficiales fueron atenuando y flexibilizándose, lo cual deja pendiente la pregunta de si esa afirmación particularista inicial no fue el modo de volver -afianzado y fortificado- a discutir y definir las condiciones de un arreglo identitario plural, así como de un acercamiento con los sectores descontentos de la sociedad boliviana tras la crisis del 2008.

\section{Ecuador y ¿un “amplio consenso ciudadano"?}

A fin de avanzar con los preparativos del bicentenario de la Primera Junta de Gobierno de Quito, el Poder Ejecutivo ecuatoriano establecía que durante el mismo una de sus prioridades sería "reforzar la identidad y la unidad nacional, mediante la

419 Discurso pronunciado por Evo Morales en Sucre, 6 de agosto de 2009. Disponible en: http:// www.bbc.com/mundo/america latina/2009/08/090806 bolivia_morales_sucre

Por otro lado, cabe destacar que un año después Sucre se quedaría sin el monopolio del festejo de independencia. Es que, en el marco de esa búsqueda por dejar atrás los divisionismos, García Linera oficializaría en julio del 2010 que, a partir de entonces, la Asamblea Legislativa Plurinacional (APL) sesionaría cada 6 de agosto de manera rotativa para que las celebraciones llegaran a todo el país. Es así que, por ejemplo durante ese año, la APL sesionó en Santa Cruz, mientras que la parada militar fue en Cobija (Pando). 
consolidación de un amplio consenso ciudadano". ${ }^{2} 20$ Poco más de un año después, las puestas en escena y los discursos oficiales desplegados para aquella ocasión daban cuenta de esa pretensión de reconciliación y armonía al momento de concebir y exhibir tanto el pasado como el presente nacional.

En efecto, el hecho de que se reivindicara la gesta criolla, al igual que la participación popular - exhibiendo al pueblo como pilar de la hazaña independentista sin caer en la postergación o condena del caudillismo liberal-; que se resaltara la importancia de los próceres quiteños, pero también de aquellos oriundos de otras regiones; que se repusiera la imagen de -al menos- una parte de la Iglesia católica comprometida con la causa libertaria y se exaltara el accionar revolucionario femenino reflejaron la intensión del gobierno de la RC por trazar una interpretación del pasado independentista mesurada, amplia y, a la vez, unitaria dirigida a disolver cualquier tipo de contradicciones o desavenencias que pudieran rebatir la idea de un origen común y coincidente de la nación ecuatoriana.

Respecto a las prácticas conmemorativas, el Poder Ejecutivo ecuatoriano incorporó al programa oficial de la celebración bicentenaria un rito indígena junto a un vasto repertorio de actividades lúdicas y festivas urbanas, de naturaleza popular y masiva, entre las cuales se incluyó, cabe resaltar, un concierto gratuito organizado en la cuidad costera de Guayaquil encargado de dar inicio a los actos oficiales del bicentenario.

En este sentido y más allá de que la tendencia a volver uno lo que, en verdad, fue disímil y/o conflictivo pueda resultar una operación usual durante las festividades patrias, es posible sostener que, en este caso puntual, ese modo particular de reconstruir el pasado nacional y estructurar la celebración bicentenaria fue expresión de un proyecto político al cual no solo le interesaba hacer a un lado los particularismos que caracterizaron a la gesta emancipadora, sino especialmente aquellos que asomaban en el presente.

Por consiguiente, aquel conjunto de prácticas y discursos conmemorativos que tuvo lugar en agosto de 2009 habría perseguido una suerte de reconciliación, equilibrio y síntesis de la pluralidad evocadores del principio del justo medio. Ese empeño por

420 Decreto Ejecutivo $\mathrm{N}^{\circ} 1023$ del 15 de abril de 2018. Disponible en: https://minka.presidencia.gob.ec/ portal/usuarios externos.jsf 
aproximar y combinar tradiciones, memorias, regiones y actores sociales fue expresión, a su vez, de un rasgo central del gobierno de la RC, a saber, su vocación universalista en donde la emancipación final de la nación solo se conseguiría unificando los particularismos, las diferencias o los regionalismos a través del concepto universal y abstracto de ciudadanía, tarea para la cual el Estado era presentado como el actor fundamental.

Si -como señalaba Correa durante el aniversario patrio- la tarea era seguir erigiendo un "gobierno de todas y todos los ecuatorianos" $421 \mathrm{y}$, para ello, era necesario combatir "el corporativismo que tanto daño" había hecho a un país que,422 incluso en ese momento, podía ser fácilmente "presa de grupos pequeñitos pero con gran poder económico, social, informativo, hasta religioso", ${ }^{423}$ entonces la construcción de un Estado capaz de encarnar el interés general constituía, sin lugar a dudas, un aspecto definitorio de su proyecto político:

El Bicentenario nos encuentra en un proceso de lucha por nuestra segunda y definitiva independencia. El desafío es lograr un Estado integral, como lo definió Gramsci, un Estado que represente a las grandes mayorías, que busque (...) el bien común. Aquí, la lucha básicamente es política: cambiar la relación de fuerzas, para que en el nuevo Estado manden los ciudadanos. 424

Así, el Poder Ejecutivo ecuatoriano explicitaba su preocupación por encontrar el justo balance y reconocer la pluralidad, siempre por medio de la conciliación y síntesis de las diferencias; fórmula en la cual la constitución y la afirmación de un orden político

\footnotetext{
421 Discurso pronunciado por Rafael Correa en Quito, 10 de agosto de 2009. Disponible en: http:// www.presidencia.gob.ec/wp-content/uploads/downloads/2013/10/10-10-09-

Discurso_posesion_Presidencial.pdf

422 Discurso pronunciado por Rafael Correa en Cuenca, 3 de noviembre de 2009. Disponible en: https:// www.presidencia.gob.ec/wp-content/uploads/downloads/2013/10/2009-11-03-CLXXXIX-

ANIVERSARIO-DE-LA-INDEPENDENCIA-DE-CUENCA-WEB.pdf

Sobre el corporativismo y la RC, se sugiere consultar el trabajo de Pablo Ospina Peralta donde explica de qué modo el primero -"acusado de un particularismo que hace daño al Estado y a las políticas estatales al hacerles perder su vocación nacional y de largo plazo"- habría resultado "para la revolución ciudadana lo suficientemente dañino como para eclipsar la plurinacionalidad" (2011: 86-95).
}

${ }^{423}$ Discurso pronunciado por Rafael Correa en Quito, 10 de agosto de 2009. Disponible en: https:// www.youtube.com/watch? $v=$ gnLQ_x3Bihk

424 Discurso pronunciado por Rafael Correa en Quito, 22 de abril de 2010. Disponible en: https:// www.presidencia.gob.ec/wp-content/uploads/downloads/2012/10/22-04-10-relevo-del-alto-mandomilitar.pdf 
exterior a la sociedad y portador del interés general se tornaban sus objetivos más fundamentales:

Y el gran debate, sobre todo en los últimos dos siglos a nivel de las grandes ideologías: ¿hasta dónde la acción colectiva y hasta dónde la acción individual? Demasiada acción colectiva mata al individuo (el estatismo), pero demasiado individualismo mata a la sociedad. Los suecos dicen: 'Una cuerdita para halar al que se dispare demasiado, y para subir al que se cae demasiado'. ${ }^{425}$

Cercana a la propuesta teórica de Norberto Bobbio (1989), la solución a este dilema vendría de la mano de un punto medio entre organicismo e individualismo, entre la tradición socialista y la democrática-liberal. Aunque, en el caso de Correa, valores como la armonía de clases, la utopía y el humanismo de inspiración cristiana eran, asimismo, irremplazables. Un maridaje que solamente podía volverse asequible por el accionar del Estado concebido como la única entidad -por fuera y por encima de la sociedad- capaz de articular, disciplinar y subordinar los intereses particulares en función del interés general. De lo que se trataba era de institucionalizarlo y desectorizarlo para garantizar la estabilidad, regular los desequilibrios sociales y asegurar un "amplio consenso ciudadano".

Por lo tanto, la representación de la memoria histórica efectuada durante la celebración bicentenaria constituyó un mecanismo más dirigido a materializar el proyecto político del correísmo, es decir, la institucionalización y desectorización del Estado con el fin de avanzar en la organización, contención y disciplinamiento de los diversos intereses presentes en la sociedad. En última instancia, a lo que apuntó, entonces, fue a exhibir y afirmar al Estado como garante y organizador de la sociedad ecuatoriana.

Así, la disposición de un orden político exterior a ella y portador del interés general - con la ciudadanía, aquella totalidad de sujetos individuales, indiferenciados e iguales, como referente- fue exhibido como una meta fundamental si lo que se quería

\footnotetext{
425 Discurso pronunciado por Rafael Correa en Guayaquil, 18 de octubre de 2011. Disponible en: https:// www.presidencia.gob.ec/wp-content/uploads/downloads/2014/05/2011-10-18-PREMIOS-

EXCELENCIA.pdf
} 
era ampliar el concepto de ciudadanía y nación y proyectar esta última hacia un horizonte temporal y fáctico.

De esta forma, un imperativo categórico de la RC consistía en suprimir o, por lo menos, atenuar la presencia de particularismos en el espacio público-político y uno de los mecanismos para alcanzarlo fue la construcción de una narrativa sobre el pasado meticulosa, flotante, abstracta y esencialista susceptible de desdoblamientos, dirigida a agrupar las diferencias y volverlas una totalidad "ciudadana". ${ }^{426}$ Ahora bien, ¿esa reactualización de la memoria histórica y aquel despliegue conmemorativo contribuyeron a zanjar las controversias en la esfera de la sociedad y el Estado y a lograr, de esa forma, su desectorización? ¿Posibilitó velar las aporías, tensiones y equívocos inherentes a este -y a todo- ordenamiento político?

Si bien la pretensión de legitimación y construcción hegemónica se vio acompañada de un interés por ensanchar lo nacional, interpelar y convocar la “diferencia”, así como reparar el espacio público en su carácter intercultural, también reforzó las viejas y nuevas tensiones políticas y regionales que entonces sacudían al gobierno de la RC, poniendo en cuestión los intentos oficiales de aunar la nación.

Por un lado, el empeño desde arriba por establecer y articular una comunidad política abstracta y general -regulada por el Estado- chocó, de manera evidente, con la existencia de intereses particulares perseguidos por quienes la integraban, lo cual

\footnotetext{
426 En este punto, resultan particularmente interesantes las palabras de Chantal Mouffe, quien repara en los problemas y límites inherentes a las búsquedas de clausura y erradicación de la diferencia propias de la filosofía liberal: "El objetivo de una política democrática no reside en eliminar las pasiones ni en relegarlas a la esfera privada, sino en movilizarlas y ponerlas en escena de acuerdo con los dispositivos agonísticos que favorecen el respeto del pluralismo.

Esas cuestiones sólo se pueden formular a partir de una perspectiva teórica que se alimente de la crítica del esencialismo, que es el punto de convergencia de corrientes teóricas tan diversas como las del segundo Wittgenstein, Heidegger, Gadamer o Derrida. Semejante crítica permite comprender los límites del pensamiento político clásico (y, en su seno, particularmente la filosofía liberal) y ver que dependen de una ontología implícita que concibe el ser bajo la forma de la presencia. Esta «metafísica de la presencia» restringe el campo de los movimientos político-estratégicos a los lógicamente compatibles con la idea de una «objetividad» social. Cuando se presenta esa objetividad como el fundamentum inconcussum de la sociedad, todo antagonismo se reduce a una simple y pura diferencia (en el sentido saussureano del término). Se la percibe como un simple efecto situado en el nivel de la apariencia y derivado de un nivel ontológico más profundo. De ese movimiento proviene la clausura constitutiva del pensamiento liberal clásico. En Hobbes, el movimiento político todavía es dominante, dada la incapacidad de la sociedad civil para autorreproducirse de manera coherente, pero luego esta posibilidad de autorreproducción se constituirá en premisa fundamental del liberalismo. Ella es la que llevará a atribuir carácter residual a lo político (esto es, al campo de los antagonismos) y a tender a su eliminación. Esta noción de totalidad que se autorreproduce (y que, por tanto, como la eternidad spinoziana, es cerrada) es el nexo entre el liberalismo y la metafísica de la presencia.

Por el contrario, cuando la clausura demuestra ser una imposibilidad lógica -como se ve en la desconstrucción-, resulta evidente que cualquier cierre es forzosamente contingente; por tanto, siempre es parcial y está fundado en formas de exclusión (y, por tanto, de poder)" (1999: 14-15).
} 
condujo, durante el aniversario propiamente dicho, a extensas polémicas con ciertos sectores de la oposición que se lanzaron a intervenir públicamente durante los mismos; pero, también y en términos más generales, a agudos conflictos y desencuentros con la clase empresarial, sectores de la izquierda, el movimiento feminista, ciertas organizaciones indígenas y ecologistas, así como los docentes y estudiantes universitarios (Ospina Peralta, 2011; Ortíz Lemos, 2014).

Por otro lado, es preciso señalar el hecho de que el correísmo logró constituirse en un movimiento político sistemáticamente ratificado por la voluntad popular y que sectores subalternos históricamente excluidos obtuvieron respuesta a sus reclamos y demandas de inclusión material y simbólica, forzando su reconocimiento en la memoria histórica de la nación y su incorporación efectiva a un concepto ampliado y resignificado de ciudadanía -en su dimensión civil, política y social, al igual que simbólica y cultural-.

En este sentido, es posible arriesgar que quizás haya sido en esa búsqueda de una ciudadanía plena, ampliada y conciliadora de la diferencia que aspiraba a suprimir la preeminencia de todo tipo de interés particular y conquistar una armonía de clases, donde yacieron expuestos tanto el límite como la eficacia del proyecto político de la RC: esa pretensión de abstracción y desectorización de la sociedad y el Estado ecuatoriano - de la cual la celebración bicentenaria y la interpretación oficial del pasado nacional y regional, evocadora del principio del justo medio, parecieron ser su expresión- aseguraba niveles de apoyo "ciudadano" inéditos para la historia del país, al tiempo que tropezaba irremediablemente con la esencia de todo ordenamiento capitalista.

\section{III. ¿Nos abrazamos y nos enfrentamos? Argentina entre la crisis y el festejo}

Frente al marcado incremento de los precios de la soja -que había significado, para el sector agroexportador, la obtención de una tasa de ganancias extraordinaria 
desde el 2003- y el estallido de la crisis financiera internacional de 2008, el equipo económico del gobierno de Fernández de Kirchner se había propuesto avanzar en un intento redistribuidor a partir de la implementación de

una modificación en la alícuota de los derechos para exportaciones (retenciones) de productos primarios, proponiendo un esquema de tasa móvil. La Resolución $\mathrm{N}^{\circ}$ 125 de marzo de 2008 ordenaba que, según las variaciones de precios internacionales, se ajustara la alícuota del tributo, lo cual en la perspectiva de ese mes significaba un aumento (...) cambio [que] produjo una fuerte reacción por parte del capital agropecuario" (Cantamutto, 2017: 70).

Este proyecto -desechado, finalmente, a mediados de 2008 en el Senado con el voto negativo de Cobos- había sido el causante de la intensa protesta rural surgida entre marzo y julio de aquel año, la cual paralizó al país y derivó en la derrota del oficialismo en las elecciones legislativas de septiembre de 2009. De esta manera, tanto el conflicto con el campo como ese revés electoral pusieron de manifiesto la ruptura de las alianzas políticas tejidas por el kirchnerismo, el desgaste del apoyo social y la presencia de un fortalecido arco opositor (Moreira y Barbosa, 2010; Sidicaro, 2011; Grimson, 2019); escenario que, en última instancia, obligaría al oficialismo a reconstruir su legitimidad política e intentar una nueva articulación hegemónica.

Bajo estas condiciones, el Poder Ejecutivo lanzaba una batería de políticas públicas de fuerte impacto político y simbólico, las cuales -dirigidas a democratizar la cultura y la sociedad argentina por medio de la ampliación y reconocimiento de derechos- fueron acompañadas por cierto repunte de la economía e impulso a la producción y el consumo.427

Justamente, esta búsqueda de apertura, articulación de diferentes demandas sociales y empeño por suturar la comunidad política - a lo cual, hay que añadir, se sumaría más tarde la preocupación por la reelección presidencial- fue la que habría

427 La estatización de los fondos de las AFJP (2008), la Asignación Universal por Hijo (2009), la estatización de las transmisiones de fútbol (2009), la ley de Servicios de Comunicación Audiovisual (2009), la ley de Matrimonio Igualitario (2010) y el plan Conectar Igualdad (2010) son algunas de las medidas que caracterizaron al ciclo político kirchnerista post 2008, junto al hecho de que fue también durante esos años que se llevaron a cabo la mayoría de los juicios por crímenes de lesa humanidad. 
servido de trasfondo a la planificación y ejecución de los festejos del bicentenario iniciados en octubre de 2009.

Recordemos que gran parte de la literatura sobre el tema identificó en las puestas en escena y los discursos oficiales desplegados a lo largo del bicentenario una profundización de la lógica populista centrada en la división dicotómica del campo social y la reivindicación de la dimensión adversativa de la política, lo cual se habría visto fundamentalmente reflejado en una apelación "revisionista" a un "nosotros" nacional y popular que, tras el agudo conflicto con el sector agroexportador, el gobierno cimentó en la oposición a un "otro" proyecto de nación ceñido al bloque "agrariomediático" y su discurso "liberal-elitista" que exaltó a la Argentina del centenario (Damilakou 2013; Stornini 2015; Suriano 2015; Molinaro 2017; Perochena 2013, 2018).

Frente a ese enfoque interpretativo, este escrito se pregunta si, en cambio, el gobierno de Fernández de Kirchner no se habría inclinado, al momento de proyectar el festejo patrio en cuestión, por una lógica discursiva liberal con el fin de matizar la partición del espacio socio-político, exhibir una nación reconciliada, interpelar a la sociedad argentina en su conjunto y, de ese modo, contribuir a la reconstrucción de su hegemonía política. 428

En este sentido, cabe reponer las palabras de la entonces presidenta de la nación al inaugurar uno de los actos principales del festejo bicentenario:

Yo quiero convocar en estos doscientos años a todos los argentinos a construir un país en el cual todos podamos sentirnos parte de él, no solamente porque se está en el Gobierno o en otro lugar, sino porque hemos sabido superar diferencias y construir un proyecto estratégico que nos guíe como fue este proyecto estratégico que tuvieron los patriotas ese 25 de mayo de 1810.429

\footnotetext{
428 Retomando los aportes de Chantal Mouffe (2006), Francisco Panizza (2008) y Benjamín Arditi (2008, 2011), entiendo por lógica liberal aquella que insiste en la relevancia de los derechos individuales, el pluralismo, la aceptación de las diferencias, así como el consenso inclusivo y racional. En cuanto a lo que podría ser denominado como lógica populista, acuerdo con estos autores que ésta, además de suponer la dicotomización conflictiva del campo político entre el "pueblo" y las estructuras de poder establecidas, involucra también, entre otras cuestiones, una potencialidad democratizante cuando viene de la mano de una política de reconocimiento de los sectores subalternos, de justicia social y de redistribución económica.
}

429 Discurso pronunciado por Cristina Fernández de Kirchner en Buenos Aires, 25 de mayo de 2010. Disponible en: http://www.casarosada.gob.ar/informacion/archivo/22233-blank-31757128 
Así, Fernández de Kirchner dejaba entrever dos de los objetivos que habrían estado detrás de la propuesta desarrollada por el Poder Ejecutivo para la conmemoración de los doscientos años de la Revolución de Mayo: por un lado, de lo que se trataba era de diseñar una celebración y una narrativa histórica de naturaleza inclusiva, amplia y, por ende, híbrida. Por el otro, lo que se buscó fue trazar y exhibir un paralelismo entre el "proyecto estratégico" de Mayo y el que se inauguró en el 2003, confluyendo en esta doble dirección las múltiples operaciones estéticas, políticas e historiográficas desplegadas, a lo largo de la denominada "semana del bicentenario", en la ciudad de Buenos Aires.

Como consecuencia de ello, tuvo lugar un importante despliegue de puestas en escena -algunas convencionales, otras innovadoras-, el cual pareciera haber respondido a la intención de generar condiciones propicias para que la celebración del bicentenario de la revolución rioplatense se convirtiera en un atractivo colectivo más allá de los posicionamientos político-partidarios e ideológicos que, por aquel entonces, dividían a la ciudadanía.

Era necesario lanzar una fiesta que movilizara, reconciliara y articulara múltiples identidades individuales y colectivas, presentándolas a todas ellas como la esencia fundante de la nación; para la cual montar un acontecimiento capaz de convocar y movilizar a un público extenso y variopinto resultaba esencial, algo que la participación de aproximadamente seis millones de personas provenientes de diversos puntos del país fue una clara muestra de su éxito. ${ }^{430}$

Pero si volvemos sobre aquellos actos o espectáculos puntuales que involucraron una reconstrucción y escenificación de la memoria histórica de la nación -como lo fueron los casos de la "Galería de los patriotas", el videomapping y el "Desfile de los 200 años"-, es posible observar cómo esa pretensión por interpelar "a todos los argentinos" más allá de las "diferencias" derivó en un complejo collage de imágenes, figuras y representaciones sumamente heterogéneas y disonantes entre sí que -además

\footnotetext{
430 Página 12, 26 de mayo de 2010. Si tenemos en cuenta que la conmemoración del bicentenario del 5 de julio en Venezuela contó con la presencia de treinta mil personas o que desde el 1 de agosto hasta el 10 de agosto de 2009 asistieron casi quinientas mil personas a los distintos eventos de la celebración bicentenaria del Primer Grito de la Independencia en Quito, salta a la vista el notable poder de convocatoria que tuvo la "semana del bicentenario" argentino.
} 
de expresar probables vicisitudes de sus respectivos procesos de elaboración, así como el peso de la tradición- respondió a una búsqueda política dirigida a reconocer las diferencias y moderar las situaciones de suma cero.

Es así que el objetivo de plantear un bicentenario, a la vez, amplio y sensible a la diferencia supuso una convivencia de estéticas, tradiciones y representaciones muy heterogéneas y disonantes entre sí, al igual que un entramado de usos del pasado complejo, ambiguo y cargado de desvíos eficaces al momento de atenuar la retórica polarizadora que había profundizado el gobierno tras la crisis política de 2008 y proyectar -sin omitir los conflictos, los adversarios o las tragedias, pero siempre remarcando que "lo bueno pesa más que lo malo" y que los argentinos "nos enfrentamos y nos abrazamos"-431 un movimiento histórico general armónico, plural y progresivo que, con avances y retrocesos, culminaba en el kirchnerismo.

Entonces, ¿cómo interpretar esta búsqueda por desplegar una fiesta patria y una memoria histórica elásticas y plurales que intentó diluir la estrategia política-discursiva del kirchnerismo centrada en la polarización y la ruptura? ¿Es posible pensar que no fue a pesar de las inconsistencias y contradicciones que acompañaron a esas puestas en escena, sino gracias a ellas que la semana de mayo de 2010 devino un acontecimiento masivo y uno de los momentos emblemáticos del gobierno entonces vigente? ¿El tan analizado discurso antagónico kirchnerista no se vio matizado, durante aquellos días festivos, por una facultad o destreza para interpretar, movilizar y mezclar los imaginarios y las identidades de diversos sectores de la sociedad?

Tras el agudo conflicto con los sectores agropecuarios $-\mathrm{y}$ un importante sector de la ciudadanía que se posicionó activamente a favor de estos últimos-, el gobierno de Fernández de Kirchner experimentó una profunda crisis de hegemonía que, eventualmente, lo obligaría a matizar sus orientaciones rupturistas o polarizadoras, desactivar las diferencias y, en este sentido, procurar reintegrar o "regenerar" el espacio comunitario. Luego de un extenso recorrido por las prácticas y los discursos conmemorativos que el Poder Ejecutivo argentino desplegó durante el bicentenario de

\footnotetext{
431 Véase la campaña oficial de difusión televisiva de los festejos bicentenarios. Disponible en: https:// www.youtube.com/watch? $v=\mathrm{x}-\mathrm{TzYv} 0 \mathrm{LubE} \&$ frags $=\mathrm{pl} \% 2 \mathrm{Cwn}$
} 
Mayo, este escrito insiste en que los mismos se inscribieron en aquel contexto y respondieron a aquellas búsquedas políticas.

De ahí que se intentara proyectar una visión sobre el pasado y la identidad nacional que contribuyera a atenuar la presencia de conflictos en el espacio públicopolítico y habilitara, a su vez, un "espacio de experiencias" y formas de encuentro capaces de interpelar a múltiples identidades y conciliar los particularismos, para lo cual la reivindicación de los emblemas y lugares comunes de la argentinidad devino una necesidad (incluidos aquellos que, en apariencia, podían resultar frívolos y/o que, por esos años, caían por fuera de o podían tensionar la identidad política del kirchnerismo).

En este aspecto, el formato fiesta resultó esencial en la medida que facilitó aquel despliegue de usos del pasado polifónico y reconciliador entre tradiciones, imaginarios y representaciones históricamente antitéticas, al tiempo que posibilitó reforzar y legitimar el -en ese entonces- recientemente vapuleado proyecto político del kirchnerismo, el cual buscó ser exhibido como heredero del "proyecto estratégico" de Mayo y como síntesis superadora de doscientos años de una historia nacional construida colectivamente.

Con todo, no se pretende anular aquí la recuperación que desde sus inicios hicieron los gobiernos kirchneristas de la interpretación del pasado esbozada por el revisionismo histórico, la cual, durante y después del conflicto con las asociaciones agropecuarias, habría sido funcional y legitimadora de su discurso polarizador y su enfrentamiento con ciertos poderes hegemónicos. Ciertamente, alusiones explícitas a determinados antagonismos centrales ubicados en el pasado (como el neoliberalismo o las experiencias dictatoriales), que el kirchnerismo había erigido en tanto su "exterior constitutivo", aparecieron en las puestas en escena y los discursos aquí analizados.

Sin embargo, lo dicho constituyó, a lo largo de la "semana del bicentenario", solo una parte -y no la central- de la cuestión. Dada la particular coyuntura política que atravesaba el país, los festejos del bicentenario, lejos de constituir un episodio más en la política de confrontación y polarización populista, involucraron una retórica centrada en la exaltación del pluralismo, así como en la posibilidad de consenso y reconciliación entre historias, memorias y posturas enfrentadas tanto en el pasado como en el presente 
argentino. De ahí que si bien "nos enfrentamos", también -y sobre todo- "nos abrazamos".

Por otra parte, el énfasis en la representación antagónica de la "parte" ocluye aquel giro que había comenzado a operar en el nivel de las prácticas políticas gubernamentales, precisamente, luego de la crisis del 2008 cuando se puso en juego la hegemonía y, por ende, la continuidad del kirchnerismo en el poder. En otras palabras, comporta una interpretación cristalizada que impide dar cuenta del carácter híbrido, cambiante y, en ocasiones, complementario de los presupuestos, lógicas discursivas y/o tradiciones a los cuales apelan los actores políticos para enfrentar los cambios y las alteraciones de la coyuntura política.

En efecto, el recorrido por las prácticas y los discursos conmemorativos dirigidos a reconstruir, historizar y escenificar el ser nacional dejó en evidencia cuánto más extensos, mixtos y conciliadores pudieron y debieron ser los usos del pasado efectuados por el gobierno cuando de lo que se trató fue de construir un acontecimiento masivo en el cual exteriorizar una identidad nacional, una memoria histórica y un proyecto político capaz de convocar e interpelar a "todos los argentinos", esto es, al momento de intentar erigirse como representante del interés general de la nación.

En este sentido, la celebración bicentenaria y la narrativa histórica allí presentada debieron nutrirse de una lógica discursiva de raíz liberal dirigida a atenuar la dimensión conflictiva de la política, esto es, equilibrar las tendencias a la partición de la comunidad mediante la ampliación de la representación, visibilización y aceptación del pluralismo, así como la reivindicación del consenso inclusivo.

Finalmente, ese giro producido tras la crisis del 2008 -del cual la celebración bicentenaria fue parte- habría tenido como epílogo al categórico triunfo de Fernández de Kirchner en las elecciones presidenciales del 2011, reflejo y consecuencia de un marcado proceso de recomposición hegemónica. Sin embargo, ese intento de proyección hacia horizontes plurales y consensuales se trató de un momento efímero que evolucionó hacia una etapa de clausura oficialista.

Como señala Gerardo Aboy Carlés, “el gobierno se encerró en un discurso y una política cada vez más expulsivos y autorreferenciales” (2014: 15), dejando atrás la búsqueda de apertura y articulación de la diferencia que había caracterizado el envite 
del kirchnerismo tras el 2008 y fundamentado las puestas en escena del bicentenario de la Revolución de Mayo, así como la interpretación del pasado nacional allí desplegada.

\section{Venezuela, ¿hacia "la consolidación plena de la patria nueva"?}

Al emprender la organización de las celebraciones bicentenarias, algunas de las metas originales que se había propuesto el Poder Ejecutivo venezolano habían consistido en desplegar "una fiesta popular en la que los pueblos nuestros americanos" fueran "los protagonistas", a la vez que "enfrentar todas las distorsiones y tergiversaciones" que se pretendieran hacer de la gesta emancipadora. 432

El resultado fueron dos extensas celebraciones patrias que, si bien registraron una serie de continuidades como la centralidad del culto a Bolívar y la exaltación de la "patria grande", imponentes desfiles o "rayos" cívicos-militares, numerosos conciertos e inauguraciones o un vasto repertorio de actividades explícitamente ligadas a la práctica militante, es posible detectar un cambio de sentido entre las efemérides aquí analizadas, el cual habría respondido a una mutación de la coyuntura política vinculada al desgaste de la hegemonía chavista y, en estrecha relación, al declive personal del líder de la RB.

Entonces, más allá de que, a primera vista, ambos sucesos hayan resultado "un canto para Bolívar", al inscribirlos en sus respectivas coyunturas políticas, no solo se vuelve factible identificar las especificidades de cada uno de ellos, sino también divisar cómo, entre ambas celebraciones, tuvo lugar un momento bisagra para el chavismo y, por ende, un trastrocamiento de los objetivos y preocupaciones que rodearon a cada aniversario patrio.

Así pues, durante el bicentenario de la Revolución del 19 de abril -luego del triunfo oficialista en el referéndum constitucional aunque en medio de crecientes dificultades económicas-, el Poder Ejecutivo venezolano procuró, ante todo, desplegar

432 Decreto $N^{\circ} 6015$ publicado el 17 de abril de 2008 en la Gaceta Oficial N ${ }^{\circ} 38.912$. Los sitios web en los cuales se solía encontrar dicha normativa ya no están disponibles. Véanse fragmentos de éstas en: https://www.albicentenario.com/index_archivos/celebracion_continental_36.html 
y reafirmar -hacia adentro y hacia afuera- la profundización del giro hacia el "socialismo del siglo XXI", proyectando una imagen de nación fuerte apoyada en la articulación entre el pueblo, las FFAA y el líder, así como en novedosas y provocadoras alianzas estratégicas con potencias capitalistas alternativas.

En este sentido, el modo en que el pasado independentista fue representado -es decir, el hecho de que la gesta emancipadora haya sido exhibida como una hazaña civil y militar- posibilitó legitimar en el presente la idea de que la nación venezolana continuaba revistiendo esa misma naturaleza. Por otra parte, las principales puestas en escena planificadas para la ocasión -la parada cívico-militar denominada "Independencia y Revolución", la sesión especial en la AN y la Cumbre del ALBAapuntaron justamente a proyectar la idea de una Venezuela sólida y pujante.

El bicentenario del 19 de abril devino, entonces, una ocasión favorable para representar la nación bajo un ordenamiento político cuya identidad hacía poco comenzaba a reconfigurarse. En este sentido, pareciera haberse concebido como un momento - de naturaleza pública y, por tal motivo, conveniente- para la objetivación del renovado proyecto bolivariano en donde la evocación mítica del pasado y la denuncia a los poderes hegemónicos tuvieron un lugar central en tanto posibilitaron al gobierno venezolano exponer, dramatizar y reafirmar su proyecto político tanto a puertas adentro como hacia el exterior. ${ }^{433}$

Esto supuso que, por un lado, en un contexto doméstico signado por la polarización política y la creciente organización de los sectores opositores, el gobierno de la RB intentara reforzar y perpetuar la alianza que más de diez años atrás le había garantizado el éxito: la articulación entre el pueblo, las FFAA y el líder. Por otro lado, bajo un clima que parecía propicio para redefinir el ordenamiento geopolítico en América Latina como consecuencia del llamado "giro a la izquierda" en la región, aquél buscaba proyectar al mundo una imagen de Estado fuerte dispuesto a enfrentar -o más bien, provocar- a las potencias hegemónicas, así como concertar y liderar nuevas alianzas estratégicas.

\footnotetext{
433 Algo que venía anticipando desde inicios del 2009 cuando, al hacer referencia a la proximidad del bicentenario del 19 de abril, insistió en la necesidad de "convertir a Venezuela en una potencia internacional". Discurso pronunciado por Hugo Chávez Frías en Caracas, 15 de febrero de 2009. Disponible en: https://www.youtube.com/watch?v=Eic6UgWlYyU
} 
De lo que se trató en aquella ocasión era de demostrar y exhibir a Caracas como la "cuna de América", es decir, como "cuna revolucionaria desde siempre y para siempre" e insistir en que "civiles y militares unidos" constituían la fórmula a partir de la cual se podía garantizar "la independencia venezolana" y, en última instancia, "asegurar" según proclamaba Chávez- "lo que el gran Jorge Luis Borges” había llamado "La Patria Perpetua". 434

En este aspecto, el año 2010 habría revestido un carácter decisivo para el gobierno de la $\mathrm{RB}$ en la medida que concentró dos acontecimientos fundamentales que ponían en juego su reafirmación simbólica-identitaria, así como política-institucional: la celebración del bicentenario de la Junta Suprema de Caracas y las elecciones legislativas para renovar todos los escaños de la Asamblea Nacional (AN); todo ello en un contexto signado por la intención de acelerar o radicalizar la "revolución socialista", pero también por una economía y unas finanzas públicas que continuaban resintiéndose. ${ }^{435}$

Ahora bien, el final de aquel año - marcado por el regreso de la oposición a la AN $y$, en consecuencia, la pérdida del control que ejercía sobre ella el oficialismo-436 dio lugar a un particular escenario político que se complejizó aún más luego de que en junio de 2011 Chávez fuera diagnosticado de cáncer. En efecto, fue esta última situación la que ratificó cuán fundamental era el líder en el movimiento chavista, principalmente a la luz de la incertidumbre y la preocupación que despertó entre sus bases la posibilidad de que el presidente no pudiera participar en las elecciones del 2012 (Lalander, 2012).437

De modo que un año después del festejo del bicentenario de la Revolución del 19 de abril las circunstancias se modificaban, encontrándose el chavismo en una posición

\footnotetext{
434 Discurso pronunciado por Hugo Chávez Frías en Caracas, 19 de abril de 2010. Disponible en: https:// www.youtube.com/watch?v=LQv8yHiP go

435 Para un análisis de la situación económica y financiera de Venezuela en el período comprendido entre 2009 y 2011, véanse López Maya y Lander (2010) y Lalander (2012).

436 Pese a que el PSUV obtuvo la mayoría de los escaños en las elecciones parlamentarias de 2010, manteniéndose como la agrupación política más fuerte de la AN, la oposición política -que decidió volver a participar en el proceso electoral- ocupó un espacio importante en el parlamento.

437 Cabe señalar que la enfermedad de Chávez no fue el único golpe al gobierno en tanto varias figuras políticas centrales del movimiento fallecieron durante el bienio 2010-2011. Asimismo, un mes antes del festejo en cuestión, el país atravesó una de las crisis carcelarias más graves hasta ese momento (Lalander, 2012).
} 
defensiva debido al aumento del respaldo electoral a la oposición, así como al clima de incertidumbre en cuanto al futuro político del país a causa del declive personal de Chávez. Paradójicamente, sería en aquel momento de mayor debilidad, es decir, durante el aniversario de los doscientos años de la firma del Acta de Independencia, cuando el líder de la RB se disponía a lanzarse - con un tono fuertemente mesiánico- a redoblar la apuesta con proyectos más ambiciosos a futuro.

Tras un mes de convalecencia en La Habana, el entonces mandatario aterrizaba por sorpresa en Venezuela la madrugada del 4 de julio, un día antes del segundo festejo bicentenario, expresando en las redes sociales con un tono entre épico y mesiánico: "Vuelvo al epicentro de Bolívar, y eso es pura llama, pura vida, es el inicio del retorno, hasta el retorno". ${ }^{438}$ Un retorno que, no obstante, era traducido por otros actores como un intento por "tranquilizar a sus seguidores, acallar cuestionamientos opositores y mostrarse al mando hacia la interna del chavismo".439

De cualquier modo, Chávez había decidido aprovechar la celebración del bicentenario de la independencia para volver a aparecer en la escena pública y revelar lo que parecía ser el comienzo de una nueva etapa de gobierno:

Los invito a que con el morral (...) del fuego patrio, con todo nuestro espíritu (...) en lo uno y en el todo, en lo individual y en lo colectivo, fortaleciendo la unidad nacional, diría Bolívar, el cuerpo nacional en un todo, el espíritu nacional en un todo, el alma nacional en un todo, venciendo los divisionismos (...) a quienes pretenden desde dentro y desde afuera debilitar y echar abajo a la patria y su independencia, derrotándolos en paz (...) los invito a que iniciemos esta nueva larga marcha hacia el 24 de junio de 2021 para que conmemoremos (...) el rayo de

${ }^{438}$ El Pais, 4 de julio de 2011. Disponible en: https://elpais.com/diario/2011/07/05/internacional/ 1309816802 850215.html

439 BBC Mundo, 4 de julio de 2011. Disponible en: https:/www.bbc.com/mundo/noticias/ 2011/07/110704 venezuela regreso hugo chavez cancer cuba jp

Más allá de que el desplazamiento del presidente a Cuba - donde fue operado con anterioridad a los festejos patrios y a donde se dirigiría con posterioridad para continuar el tratamiento- haya sido autorizado por el Parlamento, el hecho de que continuara ejerciendo el Poder Ejecutivo desde la isla sin delegarlo en el vicepresidente fue lo que condujo a profundos debates y conflictos. Es que la Constitución estipula que el órgano legislativo puede declarar la falta temporal del jefe de Estado cuando ésta es menor a 90 días, asumiendo en su lugar el vicepresidente. En caso de que la ausencia supere los 90 días, el Parlamento puede prorrogarla por otros 90 o decretar la ausencia total del mandatario. En junio, cuando Chávez pasó en Cuba casi un mes tras su diagnóstico, el Parlamento decidió no decretar su ausencia temporal, habilitando al presidente a gobernar desde la isla. 
Carabobo, la independencia nacional, la consolidación plena de la patria nueva, de la patria bolivariana, de la patria socialista. ${ }^{440}$

Así, el mandatario venezolano atenuaba su retórica polarizadora y anunciaba el inicio de una "larga marcha" hacia el 2021 con vistas a sosegar malestares, despejar dudas e insistir en que la victoria - contra su enfermedad y, en estrecha relación, contra la oposición en las elecciones presidenciales del 2012- era factible y, de hecho, estaba empezando a ocurrir.

Se abría una ciclo en donde la preocupación dominante ya no era, estrictamente, por el poder, esto es, por exhibir a Venezuela como faro de América Latina, pretender erigirla como potencia mundial o consolidar las alianzas internas del chavismo; sino que, hacia el bicentenario del 5 de julio, cuando la permanencia, la capacidad y el status del líder de la RB comenzaban a ser puestos en duda, se volvía urgente reforzar la idea de que su gobierno aun estaba en condiciones de asegurar niveles adecuados de gobernabilidad, al igual que garantizar la unidad y la estabilidad nacional, imponiéndose, de esta forma, una preocupación por el orden.

La perspectiva del porvenir y, más concretamente, la posibilidad de continuar resguardando el interés general de la nación quedaban, así, asociados a la continuidad del liderazgo de Chávez, erigido en condición de posibilidad para la realización, custodia y profundización de "la patria nueva", "bolivariana" y "socialista". ${ }^{441}$

De ahí que los más importantes y convocantes actos del bicentenario de la independencia hayan sido aquellos que tuvieron al líder de la RB como protagonista: la marcha de la Juventud Patriótica y Antiimperialista dirigida a corroborar el apoyo al entonces mandatario venezolano, el llamamiento a la ciudadanía que hizo el

\footnotetext{
${ }^{440}$ Discurso pronunciado por Hugo Chávez Frías en Caracas, 5 de julio de 2011. Disponible en: http:// www.todochavezenlaweb.gob.ve/todochavez/619-intervencion-del-comandante-presidente-hugo-chavezdurante-desfile-civico-militar-en-conmemoracion-del-bicentenario-de-la-declaracion-de-laindependencia-y-dia-del-ejercito-nacional-bolivariano

441 Cabe recordar que, al conocerse aquella victoria del oficialismo en el referéndum que aprobó la reelección indefinida, Chávez aclamó ante una multitud: "Hemos hoy abierto de par en par las puertas del futuro. Venezuela no volverá al pasado de la indignidad. (...) A partir de hoy se desata un gran potencial que estaba dormido y ese potencial se llama la patria eterna, la patria perenne (...) yo quiero recordar que hoy 15 de febrero se cumplen 190 años del día aquel en que Simón Bolívar instalaba el Congreso de Angostura y allí nació la república bolivariana (...) la república presocialista que murió con Bolívar y que hoy ha vuelto a renacer de mano del pueblo". Discurso pronunciado por Hugo Chávez Frías en Caracas, 15 de febrero de 2009. Disponible en: https://www.youtube.com/watch?v=Eic6UgWlYyU
} 
vicepresidente Elías Jaua a concentrarse en los alrededores del "balcón del pueblo" en el Palacio de Miraflores para dar la bienvenida y escuchar a Chávez y el desfile cívicomilitar del 5 de julio, el cual fue la única actividad de la agenda conmemorativa que contó con la participación del presidente.

Por lo tanto, es posible afirmar que la segunda celebración bicentenaria se ofreció como una oportunidad para intentar revertir - discursiva y simbólicamente- aquel escenario de debilidad y reforzar la idea de que Chávez seguiría conduciendo y garantizando la RB a través de una "larga marcha" hacia el bicentenario de la Batalla de Carabobo. El repentino cambio de coyuntura política hizo de la jornada patriótica un evento orientado a reforzar la figura del líder -quien, paradójicamente, reaparecía frágil y con un futuro incierto- en tanto la columna vertebral de la RB; esto es, como el único centro simbólico capaz de interpretar, sostener y aunar un movimiento y una experiencia de gobierno que crecía en fatiga y disenso. 442

Con todo, ¿es posible interpretar este giro conmemorativo más allá de las explicaciones que subrayan la voluntad de centralización y confiscación del aparato político-administrativo por parte del entonces presidente venezolano? Lo que ha sido analizado -de manera aparentemente aséptica- como un proceso de creciente imposición de un modelo autoritario y caudillista dirigido a acumular mayores parcelas de poder (Petkoff, 2005; García Larralde, 2008; Ramos Jiménez, 2011; Langue, 2013), podría ser complejizado con la idea de que Chávez se construyó, pero también fue construido -con cada elección democrática y referéndum popular, con las movilizaciones a su favor y en contra- como el símbolo más eficaz de la RB capaz de expresar, representar y condensar los intereses y/o malestares de diversos sectores de la sociedad.

\footnotetext{
442 “ ¿Se puede hablar de una crisis dentro del chavismo, o por lo menos un debilitamiento relativo, incluso antes de la oficialización de la enfermedad de Chávez en junio del 2011?", se preguntaba Lalander para responder a continuación: “Creo que sí, y por diferentes razones. La tendencia electoral indica hacia un debilitamiento en apoyo: entre 1998 y 2006 el oficialismo obtuvo alrededor de $60 \%$ en los comicios y referéndums populares, pero posteriormente su apoyo popular ha disminuido a $50 \%$ aproximadamente (...) Considerando el descontento social asociado a los colapsos temporales de los sistemas de electricidad y agua, así como la constante crítica incluso entre las bases chavistas de la mala administración gubernamental, puede interpretarse como sorprendente que el oficialismo aún cuenta con alrededor del $50 \%$ de apoyo según los procesos electorales (p.ej. Wilpert, 2010). (...) entre las bases vecinales chavistas generalmente hay una confianza sólida en el máximo líder, es decir en Chávez, pero frecuentemente se muestran más escépticos hacia las estructuras representativas del chavismo y se critica la ineficiencia y la burocracia institucional, el oportunismo, clientelismo, corrupción y mentalidad individualista capitalista de algunos parlamentarios, líderes subnacionales e incluso dirigentes comunales" (2012: 309-310).
} 
Esto explicaría, a su vez, por qué el diagnóstico de su enfermedad y la posibilidad de que debiera correrse de la escena política se impusieron sobre la celebración del bicentenario de la independencia, volviéndola un acontecimiento mayormente dirigido a afirmar y persuadir que, incluso en medio de un contexto acuciante y desafiante donde "la consolidación plena de la patria nueva" parecía volverse cada vez más inasequible, Chávez seguiría siendo el encargado de garantizar la integridad y la estabilidad del Estado y la nación.

VI. Fiesta, representación colectiva y disputa hegemónica. Cuartas consideraciones provisorias

A lo largo de estas páginas, se propuso una reflexión sobre las celebraciones bicentenarias en tanto sucesos puntuales donde se habrían visto enunciados de manera paroxística las identidades, las búsquedas y los proyectos políticos de aquellas cuatro experiencias de gobierno durante ese particular momento histórico. Sin embargo, para avanzar hacia esa dirección resultó ineludible ponerlas en diálogo con su contexto más general, esto es, inscribirlas en las fuerzas y circunstancias que influyeron sobre las mismas. Pero sobre todo a fin de analizar de qué modos los discursos y las puestas en escena de carácter festivo y conmemorativo pretendieron afianzar o revertir la marcha de la política en cada una de estas naciones.

En el caso del Poder Ejecutivo boliviano, lejos de buscar trazar -sobre todo inicialmente- un acontecimiento y una narrativa histórica de tintes abarcadores, éste pretendió restituir y devolver a los pueblos indígenas - de origen quechua y aymara- el lugar que históricamente carecieron en la memoria histórica de la nación, a la vez que extender, en medio de un clima de abierta hostilidad, una retórica de intransigencia hacia los sectores opositores autonomistas. Ahora bien, ese empeño por reforzar y hacer prevalecer esa raíz identitaria -exhibida como la esencia de la nacionalidad boliviana- 
conspiró contra sus intenciones originales de integrar el país y erigir la imagen de un Estado capaz de encarnar y asegurar el bien común o el interés general de la nación.

Respecto a Ecuador, las tentativas del gobierno de la RC por celebrar y escenificar la memoria histórica de la nación durante el bicentenario de "independencia" pusieron de manifiesto sus pretensiones universalistas, al igual que su preocupación central: conseguir una comunidad ciudadana unida y regulada por el Estado donde los intereses particulares -de clase, etnia o género- se vieran disueltos o, por lo menos, morigerados. En términos generales, lo que se buscó fue reponer la idea de un Estado fuerte y autónomo, organizador y garante de la sociedad ecuatoriana, luego de décadas de inestabilidad política e institucional.

En Argentina, el gobierno de Fernández de Kirchner ensayó, durante el bicentenario de la Revolución de Mayo, un intento de proyección hacia horizontes plurales y consensuales dirigido a atenuar las tendencias polarizadoras que habían caracterizado a su retórica y práctica política inmediatamente después de la crisis del campo. Aunque solo haya sido por un período de tiempo acotado, las puestas en escena planificadas para aquella ocasión apuntaron a esbozar una idea de nación amplia que contemplara -sin diluir las diferencias- múltiples identidades individuales y colectivas, así como la imagen de un Estado que era capaz de visibilizarlas, contenerlas y representarlas.

Por último, en el marco del bicentenario de la Revolución del 19 de abril, el Poder Ejecutivo venezolano aspiró -a través de una retórica provocadora- a proyectar una imagen de nación próspera y fuerte que, como antaño, se asentaba en la unión entre civiles y militares conducida por un líder cuya tarea era consumar la empresa de Bolívar. Más de un año después, los festejos oficiales del 5 de julio recogían y expresaban una nueva preocupación política: convencer de que todo marcharía bien y de que el entonces mandatario debía seguir al frente del proceso bolivariano, al menos, una década más. Garantizar el orden y proteger el interés general de la nación se convertían, así, en sinónimo de ratificar la permanencia del líder de la RB al mando del aparato estatal.

De esta manera y más allá de los elementos en común que efectivamente tuvieron los repertorios festivos desplegados en cada aniversario patrio, lo que este capítulo puso 
de relieve fue la existencia de diferentes preocupaciones y búsquedas políticas, así como de formas de concebir al Estado o la nación en el marco de coyunturas críticas donde estaba en juego, en mayor o menor medida, la capacidad hegemónica de esas fuerzas políticas.

Es así que este recorrido final no aspiró a determinar en qué consistió el llamado "giro a la izquierda" o identificar una supuesta "esencia" del mismo, sino a examinarlo, a partir del análisis de casos, como un fenómeno histórico -y, por lo tanto, cambiante en el tiempo y el espacio- compuesto por ordenamientos políticos con objetivos, apuestas e intereses políticos distintos $\mathrm{y}$, más específicamente, atravesados todos ellos por estrategias diferentes y flotantes de preservar y/o acrecentar su legitimidad y capital políticos, así como de lidiar con el desafío irresoluble de que el Estado asegure la representación colectiva de la comunidad nacional. 


\section{Conclusiones}

Reflexionar acerca del pasado reciente en un espacio tan vasto y heterogéneo como el que comprenden los cuatro países aquí seleccionados constituyó, sin dudas, una tarea arriesgada, si tenemos en cuenta la probabilidad de extraviarse en operaciones homogeneizadoras, anacrónicas y/o simplificadoras. No obstante, la posibilidad de alcanzar un atisbo del todo y de ofrecer una posible vertebración de la experiencia regional -sorteando las caracterizaciones rígidas y/o estrechas $\mathrm{y}$, especialmente, los esencialismos y maniqueísmos- fue lo que nos animó a asumir el desafío.

Esta tesis se propuso, entonces, contribuir a la comprensión de un momento particular de cuatro experiencias de gobierno que una vasta literatura englobó y enmarcó en el llamado "giro a la izquierda" puesto en marcha en la región en los albores del siglo XXI, situando la atención en un conjunto de discursos, prácticas y representaciones que se habían visto mayormente descuidados por las investigaciones sobre el fenómeno en cuestión.

Así pues, escogimos las celebraciones de los bicentenarios de "independencia" proyectadas por los Poderes Ejecutivos de Argentina, Bolivia, Ecuador y Venezuela, partiendo de la hipótesis de que su análisis podía resultar valioso al momento de desentrañar ciertas características que entonces habían rodeado a cada una de esas experiencias gubernamentales.

Examinar los intentos por disputar, restaurar y celebrar las memorias históricas de cada nación bajo circunstancias excepcionales - esto es, en el marco de un nuevo centenario del inicio de la gesta emancipadora que, a su vez, se vio entrelazado a decisivos momentos políticos, sociales y/o institucionales- constituyó, entonces, la vía elegida para reflexionar sobre los modos en que esos actores se vincularon con el pasado, delinearon sus filiaciones ideológicas, replantearon ciertas identidades y, en 
última instancia, tramitaron los problemas de la gobernabilidad, de la construcción hegemónica y la representación del bien común.

Para ello, se indagó, en primer lugar, en la producción de los regímenes conmemorativos de los bicentenarios de "independencia". Luego de profundas crisis sociales, políticas y económicas, una de las principales preocupaciones de los Poderes Ejecutivos se vinculó a fomentar la unidad y la consolidación de cada nación, así como de la región. Aunque no se haya visto explicitado en todas las normativas relativas al tema, propiciar el protagonismo del "pueblo" y reivindicar sus tradiciones, memorias e intereses constituyó, asimismo, una meta compartida. Por último, en todos los casos la idea de consumar las fallidas "independencias" emergió rápidamente como un eje retórico común.

En consecuencia, la celebración de los doscientos años del inicio del proceso de independencia fue concebida por esos actores como una ocasión excepcional para reconfigurar las identidades nacionales, reexaminar y reestructurar -habida cuenta de las exigencias y los desafíos que los rodeaban- sus propias identidades políticas y, en última instancia, exhibir una afinidad o concurrencia entre la esencia "auténtica" de esas naciones y la naturaleza y vocación de sus apuestas y proyectos políticos.

Una de las formas en que aquello intentó ser alcanzado fue por medio de la revisión de las narrativas, héroes e hitos de la nación. Cuestionar y restaurar esos puntos de referencia devino, así, una meta fundamental para los cuatros Poderes Ejecutivos, los cuales bucearon en el pasado y seleccionaron un abanico de tradiciones, personajes y acontecimientos que posibilitaban, por un lado, reconocer y recoger las demandas de inclusión simbólica de vastos sectores subalternos y, por el otro, afianzar sus proyectos políticos e ideas de nación.

Si bien esas maneras de representar el pasado -orientadas a democratizar las memorias históricas y a validar, al mismo tiempo, la continuidad y excepcionalidad de los procesos políticos en cuestión- pusieron de manifiesto sus ansias refundacionales, ello no implicó el completo abandono de las formas, enfoques, figuras y/o imaginarios tradicionales y, en estrecha relación, populares de narrar la nación.

En este sentido, el análisis de los usos oficiales del pasado efectuados durante las celebraciones bicentenarias reveló - como fue señalado en el capítulo dos- que la 
vinculación con el mismo, así como su reconstrucción con fines simbólico-identitarios y político-partidarios constituyen operaciones complejas, cargadas de ambigüedades y contradicciones, que vuelven difícil y, usualmente, artificioso intentar conferirles una apariencia de lógica unívoca, congruencia o impermeabilidad.

Otra de las vías a partir de las cuales los aludidos Poderes Ejecutivos intentaron reconfigurar ciertos arreglos identitarios y legitimar sus proyectos políticos fue a través de los repertorios festivos desplegados a lo largo de los aniversarios patrios. El conjunto de prácticas y/o discursos conmemorativos de carácter protocolar e institucional, al igual que las formas populares y masivas de festejar la nación constituyeron, así, otro mecanismo más para reordenar y readaptar las simbologías, liturgias e identidades políticas de acuerdo a las búsquedas, necesidades y/o circunstancias del momento.

No obstante, el recorrido trazado en el capítulo tres también apuntó a matizar el peso explicativo de la variable ideológica en las formas de sociabilidad festivas acontecidas durante los bicentenarios $\mathrm{y}$, sobre todo, a dar cuenta cómo en ocasiones el desarrollo de éstas se vinculó exclusivamente a su virtud para agradar y divertir al público, al igual que a los dirigentes políticos encargados de presidir las celebraciones patrias.

En rigor, lo que nuevamente se buscó poner en cuestión fueron las imágenes cristalizadas o compartimentadas, esta vez, relativas a los repertorios festivos del bicentenario -y a sus formas estéticas, simbólicas y culturales- e insistir sobre la relevancia de pensar las articulaciones entre política y frivolidad. Aunque superficialmente contrarias o ajenas, ambas nociones poseen una riqueza analítica capaz de contribuir a lograr caracterizaciones más precisas y reales de un determinado fenómeno, acontecimiento o proceso histórico.

Ahora bien, en todos los casos examinados la llegada de los bicentenarios coincidió con momentos políticos álgidos y decisivos caracterizados por la agudización de diferentes conflictos sociales y/o regionales, la pérdida de capital político, la incertidumbre en cuanto a la continuidad en el poder y/o la proximidad de elecciones presidenciales. Esta situación colaboró a que tanto los festejos como los intentos oficiales por revisar las narrativas de la nación reactivaran y vehicularizaran una serie de tensiones, debates y desacuerdos en la escena pública, los cuales sirvieron para 
reponer y extender una amplia gama de aclamaciones, denuncias y reproches a los ordenamientos políticos vigentes en cada país.

De modo que, empeñados en la tarea de presentar sus causas, pareceres e intereses particulares como los de la nación, no solo los Poderes Ejecutivos y sus simpatizantes, sino también vastos sectores críticos a los mismos identificaron en esos acontecimientos o circunstancias conmemorativas provechosas instancias para vindicar y dar cauce a sus agendas, visiones o búsquedas político-ideológicas.

Finalmente, este trabajo se detuvo en las maneras en que las puestas en escena y los discursos oficiales de carácter festivo y conmemorativo desarrollados durante los bicentenarios de "independencia" se enraizaron en dinámicas internas, líneas y tradiciones políticas particulares, a la vez que oscilaron de acuerdo a los intereses $\mathrm{y} / \mathrm{u}$ objetivos que cada Poder Ejecutivo se había propuesto satisfacer, conduciendo todo ello a formas disímiles de conmemorar y disputar la nación.

Por lo tanto, más allá de las similitudes producto de los “efectos de repercusión”, las conexiones y las afinidades entre los cuatro casos aquí seleccionados, el capítulo quinto aspiró a captar lo que cada experiencia histórica había tenido de concreto en ese período, es decir, a desentrañar y prestar atención a las especificidades de cada uno de los festejos y los sentidos e implicancias más generales que de éstos se desprendieron.

Empero y sin el afán de volver sobre lo ya dicho, es posible apuntar que en todos los casos hubo una articulación racional y afectiva de los bicentenarios, esto es, un intento por convertirlos en celebraciones dirigidas, dependiendo el caso, a apuntalar consensos, reafirmar alianzas, nutrir ciertos antagonismos y/o reconstruir la hegemonía, pero también $-\mathrm{y}$ ciertamente en estrecha vinculación aunque difícilmente subsumible a esos objetivos- a entretener, movilizar y convocar a vastos sectores de la sociedad, a la vez que englobarlos dentro de sus proyectos de reconstrucción cultural de cada nación y sus promesas de porvenir.

A fin de cuentas, de lo que se trató fue de demostrar que el llamado "giro a la izquierda" podía ser pensado desde múltiples ángulos y que los modos en que esas experiencias gubernamentales habían restaurado, representado y celebrado el pasado constituía uno de ellos en la medida que podían contribuir a decir algo más sobre las mismas, así como sobre su clima de época. Puntualmente, en lo referido a ciertas metas, 
ansiedades, desafíos y vaivenes políticos imperantes en ese particular momento histórico y, también, respecto a las formas singulares en que aquellos actores lidiaron, durante las celebraciones patrias, con la cuestión de la representación y custodia del interés general de la nación.

Para avanzar en ese sentido y frente a la abundancia de análisis que atendieron a factores materiales o estrictamente políticos e institucionales, consideramos conveniente proponer otra forma de acercamiento que -haciendo referencia o, incluso, apoyándose en los primeros- se ocupara, sin embargo, de aspectos culturalmente construidos como los símbolos, las memorias, las identidades y las celebraciones patrias.

Fue así que se delineó un problema de investigación a partir de esa serie de acontecimientos festivos que, si bien ocurrieron en tiempos y espacios distantes y fueron proyectados y/o liderados por cuatro personalidades completamente divergentes, remitían a una coyuntura histórica común y, por ende, tenían el potencial de arrojar luz -desde lugares disímiles aunque convergentes- sobre la misma.

Trabajar esta tensión fue uno de los desafíos que enfrentó el presente estudio, para lo cual propusimos tomar esos acontecimientos y leerlos intensamente, esto es, recuperar aquellos aspectos en apariencia más formales, representativos y/o significativos, pero también observar y extraer la "densidad semántica” de lo que suele presentarse $-\mathrm{y}$, en ocasiones, desecharse- como insustancial, accidental, irrelevante o residual;443 bajo la expectativa de que todo ese conjunto de elementos heterogéneos posibilitaría recrear los aspectos sorpresivos y/o incongruentes de los festejos y, en última instancia, apreciar el carácter más bien grisáceo y movedizo de fenómenos políticos como el chavismo, correísmo, evismo o kirchnerismo.

En este camino, reconstruir e interpretar las perspectivas y significaciones que los propios actores habían querido imprimir a los bicentenarios de "independencia" constituyó una tarea esencial en la medida que, "aun si enteramente ilusorias, no dejaron de influir en las estrategias y en las acciones políticas concretas. Como fuera

\footnotetext{
443 Una vez más, Sarlo escribía: “Quiero leer, para decirlo muy brevemente, la densidad de lo que parece irrelevante o residual, con la idea de que los mundos imaginarios ajenos a una referencia empírica se acercan a ella por el camino de la alegoría fracturada y de la narración que transcurre en varias superficies de sentido, ninguna de las cuales es más periférica o más central que otras" (2007b: 132).
} 
clásicamente dicho, hace muchos años, si determinados fenómenos son percibidos como reales, ellos son reales en sus consecuencias" (Devoto, 1996: 95).

Ahora bien, esa descripción, recuperación e intento de fidelidad a los sentidos que sus protagonistas habían otorgado a las prácticas y los discursos allí exhibidos tampoco debía suponer adoptar, reproducir ni convertir en claves explicativas las interpretaciones o lecturas por ellos impuestas (y por ellos me refiero a quienes se encargaron de concebir y reivindicar las celebraciones patrias, así como a quienes intervinieron críticamente durante las mismas).

Aunque evidente, conseguir arribar a un análisis crítico de las aludidas experiencias políticas en tiempos de bicentenarios implicaba recobrar y explicitar esos sentidos, a la vez que trascenderlos, inscribirlos en sus contextos más generales y procurar desnaturalizarlos. En resumen y atendiendo a las dificultades que enfrentan quienes deciden - como apuntaba Rousso- "dirigir una mirada histórica a su propio tiempo", el presente trabajo también se esmeró por evitar apropiarse de las polémicas e inquinas entonces vigentes y volverlas la principal clave de lectura de los acontecimientos y fenómenos políticos en cuestión.

Esto no significa, por cierto, que a lo largo de estas páginas no se haya incurrido en "omisiones selectivas". Además de que ningún lugar de enunciación o campo de visión resultan omnicomprensivos, cabe recordar que "cada vez que queremos ejercitar una mirada historizada y crítica, nosotros también -sabiéndolo o no- tenemos los fantasmas de las generaciones pasadas rondando sobre nuestras cabezas" (Briones, 1994: 117).

Con todo, esta tesis pretendió igualmente -con sus errores, límites y eventuales virtudes- reflexionar sobre una problemática más general. De modo que hemos arribado al fin de este recorrido $\mathrm{y}$, sin embargo, resulta importante efectuar una última observación. Al examinar el siglo XIX latinoamericano, John Tutino ha insistido que "La historia del poder y de la cultura aparecen como inseparables, en constantes y complejas contiendas por forjar las sociedades nacionales" (1997: 532).

Esta idea -que, en verdad, no resulta exclusiva del pasado decimonónico de la región- fue la que guió la construcción y el desarrollo de nuestro problema de investigación. En las contiendas por tramar, revisar y proyectar imaginarios, tradiciones 
e identidades nacionales, el pasado -en sus múltiples manifestaciones- constituye, como hemos observado a lo largo de este estudio, un insumo fundamental disponible para ser usado, reapropiado, potenciado o, inclusive, "superado".

Aún así y más allá de su carácter maleable, cabe preguntarse por los límites que enfrentan los actores al momento de llevar adelante esas operaciones. En este sentido, creemos que el pasado de una sociedad se presenta siempre con un peso propio que quienes buscan intervenir sobre el mismo no pueden ignorar. Entonces, volviendo sobre nuestro objeto de estudio, es posible sostener que, no obstante los anhelos refundacionales que manifestaron las experiencias políticas aquí estudiadas, hay elementos de aquél -imágenes, valores y representaciones- y determinados modos de concebirlo -mitos, rituales, relatos y liturgias- sedimentados en el tiempo de los que difícilmente pudieron prescindir o desechar.

Al revisitar y procurar redefinir las memorias históricas de cada nación con el objetivo de cimentar y/o rearmar su hegemonía, así como restaurar ciertas identidades colectivas y reconstruir "espacios de experiencias" compartidos, los Poderes Ejecutivos debieron inevitablemente contemplar o respetar varias piezas y fundamentos constitutivos de las mismas. De acuerdo con esto, podría decirse que hacer tabula rasa del pasado resulta impracticable si lo que se pretende es garantizar la unión, la continuidad y, en estrecha relación, el orden de un determinado grupo social.

Como ha sido advertido por Arjun Appadurai:

[El] cambio cultural no es reacio ni radical. Es el tipo de adaptación no dramática que podemos entender mejor si comprendemos que el pasado es un recurso cultural gobernado por reglas, por ende, finito. Al igual que con otro tipo de reglas culturales todo es posible pero solo algunas cosas son permisibles. (...) La cultura está abierta a revisiones, revitalizaciones o subversiones. Es la función de las normas que gobiernan los ineludibles debates acerca del pasado asegurar que, cuando el cambio ocurre, no sea completamente a costa de la continuidad de la cultura (1981: 218. Traducción mía).444

\footnotetext{
444 En el original: “( $\ldots)$ culture change is neither reluctant nor radical. It is the kind of undramatic accommodation that we can better understand if we grasp that the past is a rule-governed, therefore finite, cultural resource. As with other kind of cultural rules anything is possible but only some things are permissible. (...) Culture is open to revision, revitalization or subversion. It is the function of norms governing the unavoidable debates about the past to ensure that when change does occur it is not entirely at the cost of culture continuity" (Appadurai, 1981: 218).
} 
Si bien "todo es posible" al momento de reconstruir y usar el pasado, proyectar conmemoraciones y celebraciones patrias $\mathrm{y}$, en términos más generales, restaurar la memoria histórica de una nación, existe siempre un marco de lo admisible que, en un principio, condicionaría el alcance de esa potencialidad. ${ }^{445}$

Así pues, este estudio en torno a las prácticas y los discursos conmemorativos desplegados durante las celebraciones bicentenarias en Argentina, Bolivia, Ecuador y Venezuela también se esforzó por abordar y comprender de qué maneras las memorias históricas y las identidades colectivas son construcciones históricamente variables, es decir, en constante movimiento que suponen múltiples debates y pugnas, los cuales, aún cuando "ganados", se ven atravesados por una serie de obstáculos y limitaciones en la medida que toda reelaboración y representación del pasado se halla inevitablemente estructurada por concepciones, marcos y esquemas internalizados en la sociedad y las instituciones estatales, los cuales operan como frenos - ¿y garantías?- a la hora de reorganizar la experiencia colectiva y legitimar nuevas narrativas y/o fenómenos históricos.

\footnotetext{
445 Incluso en casos de transformación estructural, la necesidad de asegurar la continuidad de un grupo o comunidad cohesionada en torno a una identidad obligó a contemplar y apelar a determinadas tradiciones y/o fragmentos del pasado, así como a ciertos formatos clásicos de exhibirlos y representarlos. De esta manera, como hemos trabajado en otro lugar para el caso de la Revolución Cubana, el centenario del Grito de Yara fue aprovechado para trazar un vínculo entre el ideal del hombre nuevo y la tradición nacional: "En el discurso pronunciado por Fidel Castro el 10 de octubre de 1968 la historia se condensaba en tres episodios gloriosos, los cuales confirmaban que la revolución había sido una sola: la gesta de independencia de 1868 a 1898, la revolución de 1930 y la revolución de 1959. El culto al héroe exhibido durante el período republicano continuaba pero ahora Carlos Manuel Céspedes, José Martí y José Antonio Maceo - "símbolo(s) de la liberación nacional contra la colonia y el imperialismo"- eran ligados a Vladimir Lenin - "forjador de la primera revolución socialista"-y Fidel Castro. Se buscaba conciliar las guerras de independencia con el proyecto socialista, patriotismo e internacionalismo, exaltando la figura del líder, los milicianos y el pueblo" (Amorebieta y Vera, 2017: 85).

Por otro lado, también es posible remontarse a la Francia revolucionaria, donde "las fiestas cívicas de la Revolución no tienen un carácter transgresor, no son la incongruencia, ellas tiene un orden y un sentido y en ellas el hombre se reitera en sus conductas culturales ancestrales". De hecho, el "desorden fue efímero; la Convención lo consideró peligroso y sospechoso y lo prohibió; instaurando como alternativa al desenfreno, el culto al ser Supremo y declarando a la vez la libertad de cultos, lo cual suponía el respeto a la religión tradicional" (Acevedo Carmona, 1992: 91-92).
} 


\section{Bibliografía}

Aboy Carlés, Gerardo (2001), Las dos fronteras de la democracia argentina, Rosario: Homo Sapiens.

(2013), "El radicalismo yrigoyenista y el proceso de nacionalización del espacio político: Una interpretación a través de los usos del concepto de hegemonía”. En: Identidades, volumen 4, número 3, pp. 33-47. URL: https://iidentidadess.files.wordpress.com/2013/06/3-identidades-4-3-2013-aboycarles.pdf

(2014), "El declive del kirchnerismo y las mutaciones del peronismo". En: Nueva sociedad, número 249, pp. 4-15. URL: http://nuso.org/ $\underline{\text { media/articles/downloads/3998_1.pdf }}$

Acevedo Carmona, Darío (1992), "Religiosidad, fiestas y cultos en la revolución francesa". En: Revista de Extensión Cultural, número 29-30, pp. 85-92. URL: http://www.bdigital.unal.edu.co/53546/1/darioacevedocarmona.1992.pdf

Acha, Omar (2011), "Desafíos para la historiografía en el Bicentenario Argentino". En:

PolHis, número 8, pp. 57-69. URL: http://historiapolitica.com/datos/boletin/ polhis8_ACHA.pdf

Adamovsky, Ezequiel (2012), "El color de la nación argentina. Conflictos y negociaciones por la definición de un ethnos nacional, de la crisis al Bicentenario". En: Jahrbuch für Geschichte Lateinamerikas-Anuario de Historia de América Latina, número 49, pp. 343-64. URL: https://core.ac.uk/download/pdf/ 158830182.pdf

Affigne Oropeza, Carmen (2015), "Representaciones persuasivas de la nación: retórica argumentativa, exhibiciones y tensión en el centenario de la Independencia en 
Chile y Venezuela (1910-1911)" (Tesis doctoral). Universidad de Chile, Santiago de Chile. URL: http://repositorio.uchile.cl/handle/2250/136576

Agulhon, Maurice (1977), "Fête spontanée et fêtes organisées à Paris en 1848". En: Jean Ehrard y Paul Viallaneix (Dirs.), Les fêtes de la Révolution, París: Société des Études Robespierristes, pp. 243-271.

Alcántara, Manuel (2008), "La ubicación ideológica de presidentes y partidos de izquierda en América Latina”. En: Nueva Sociedad, número 217, pp. 72-85. URL: https://nuso.org/articulo/la-ubicacion-ideologica-de-presidentes-y-partidos-deizquierda-en-america-latina/

Altamirano, Carlos y Sarlo, Beatriz (1980), "La Argentina del Centenario: campo intelectual, vida literaria y temas ideológicos”. En: Hispamérica, número 25/26, pp. 33-59.

Álvarez Sepúlveda, Humberto y Martínez Llamas, David (2014), “Celebrando la independencia. Una resignificación en Chile y Argentina (1810-1910)”. En: Temas Americanistas, número 32, pp. 127-148. URL: https://idus.us.es/xmlui/ $\underline{\text { handle } / 11441 / 31697}$

Amati, Mirta (2013), "El tedéum en el contexto del bicentenario: usos y sentidos del rito en Argentina”. En: Sociedad y religión, volumen 23, número 40, pp. 44-76. URL: ht t p: / / w w w. sc i e 10 . o r g.a r / s c i e 10 . php? pid $=$ S1853-70812013000200003\&script $=$ sci abstract

Amorebieta y Vera, María Laura (2017), “Conmemorar la nación. Narrativas y puestas en escena de las memorias históricas latinoamericanas”. En: Osvaldo Barreneche, Andrés Bisso y Jorge Troisi Melean (Coords.), Historia de América Latina. Recorridos temáticos e historiográficos. Siglos XIX y XX, La Plata: EDULP, pp. 76-95. URL: http://www.memoria.fahce.unlp.edu.ar/libros/pm.540/pm.540.pdf (2019), “'Bolivia es una sola montaña'. Apuntes sobre los discursos y las representaciones en torno a la nación elaborados por el gobierno del MAS durante el 2009”. En: Revista Humanidades de Costa Rica, volumen 9, número 2. URL: https://revistas.ucr.ac.cr/index.php/humanidades/ article/view/37125 
Anderson, Benedict (2013) [1993], Comunidades Imaginadas. Reflexiones sobre el origen y la difusión del nacionalismo, México: Fondo de Cultura Económica.

Arditi, Benjamín (2008), “Arguments about the Left Turns in Latin America. A PostLiberal Politics? En: Latin American Research Review, volumen 43, número 3. URL: https://www.jstor.org/stable/20488150 (2011), La política en los bordes del liberalismo. Barcelona: Gedisa.

Appadurai, Arjun (1981), “The past as a scarce resource”. En: Man. Royal Anthropological Institute of Great Britain and Ireland, volumen 16, número 2, pp. 201-219. URL: https://www.jstor.org/stable/2801395

Balandier, Georges (1994), El poder en escenas. De la representación del poder al poder de la representación, Barcelona: Paidós.

Bermúdez, Emilia y Martínez, Gildardo (2000). "Hugo Chávez: la articulación de un sentido para la acción colectiva”. En: Espacio abierto, volumen 9, número 1, pp. 54-77. URL: http://www.redalyc.org/articulo.oa?id=12290104

Bertonha, João Fabio (2010), “Adquisiciones de armamentos y reequilibrios geopolíticos: América del Sur en la primera década del siglo XXI”. En: Relaciones Internacionales, número 39, pp. 109-127. URL: http:// sedici.unlp.edu.ar/handle/10915/25887

Bertoni, Lilia Ana (1992), "Construir la nacionalidad: héroes, estatuas y fiestas patrias, 1887-1891”. En: Boletín del instituto de historia argentina y americana "Dr. E. Ravignani”, número 5, pp. 77-111.

(2001), Patriotas, cosmopolitas y nacionalistas: la construcción de la nacionalidad argentina a fines del siglo XIX, Buenos Aires: Fondo de Cultura Económica.

Besoky, Juan Luis (2013), “La derecha peronista en perspectiva”. En: Nuevo Mundo Mundos Nuevos. URL: https://journals.openedition.org/nuevomundo/65374 Bieber, León Enrique (1994), “La política militar alemana en Bolivia, 1900-1935”. En: Latin American Research Review, volumen 29, número 1, pp. 85-106. URL: https://www.jstor.org/stable/pdf/2503645.pdf?seq=1\#page scan tab contents 
(2000), El comercio germano-boliviano, 1936-1939: un fracaso

singular en el contexto del comercio de compensación de Alemania con América Latina, Madrid: Iberoamericana.

Bisso, Andrés (2009), Sociabilidad, política y movilización. Cuatro recorridos bonaerenses (1932-1943), Buenos Aires: Buenos Libros.

(2010), "El lugar de los carnavales y de las fiestas cívico-patrióticas en las ciudades y pueblos de la Provincia de Buenos Aires durante la década de 1930”. VI Jornadas de Sociología, Facultad de Humanidades y Ciencias de la Educación, Universidad Nacional de La Plata, La Plata, 9 y 10 de diciembre de 2010. URL: http://www.memoria.fahce.unlp.edu.ar/trab_eventos/ev.5773/ev. 5773.pdf

(2011), "La revista de Educación bonaerense durante el período de gobierno de Manuel A. Fresco (1936-1940). Acerca de los 'usos del pasado' en los discursos y las prácticas escolares”. En: Clío \& Asociados, número 15, pp. 27-52.

Bisso, Andrés y Kahan, Emmanuel (2014), "Introducción”. En: Andrés Bisso, Emmanuel Kahan y Leandro Sessa (Eds.), Formas politicas de celebrar y conmemorar el pasado (1930-1943), La Plata: Ceraunia.

Bisso, Andrés, Kahan, Emmanuel y Sessa, Leandro (2014), Formas políticas de celebrar y conmemorar el pasado (1930-1943), La Plata: Ceraunia.

Bisso, Andrés y Kraselsky, Javier (2010), “Dos distancias al pasado. El lugar de las Invasiones Inglesas en la mirada retrospectiva de los patriotas (1810-1821) y en las celebraciones históricas de los nacionalistas en torno a la Segunda Guerra Mundial". En: Osvaldo Barreneche y Andrés Bisso (Comps), Ayer, hoy y mañana son contemporáneos. Tradiciones, leyes y proyectos en América Latina, La Plata: Edulp.

Blanco, Ronald y Linares, Rosalba (2008), “Chávez en la política exterior venezolana: (ALCA Vs ALBA) de la democracia representativa a participativa”. En: Aldea Mundo, volumen 13, número 26, pp. 49-58.

Bloch, Marc (1992), "Por una historia comparada de las sociedades europeas". En: Marc Bloch, Una historia viva, Buenos Aires: Centro Editor de América Latina, pp. 63-98. 
Blumenberg, Hans (2008), La legitimación de la Edad Moderna, Valencia: Pre-Textos.

Bobbio, Norberto (1989), Liberalismo y democracia, México: Fondo de Cultura Económica.

Bridikhina, Eugenia (2007), Theartum mundi: entramados del poder en Charcas colonial, La Paz: IFEA/LURAL.

(2010), "La propaganda política y creación del nuevo lenguaje festivo en los primeros años de la república de Bolivia: rupturas y continuidades”. En: Espacio, Tiempo y Forma, Serie V, Historia Contemporánea, número 22, pp. 235-255. URL: http://revistas.uned.es/index.php/ETFV/article/view/1556

(2013), "Cuando se callaron los cañones: conmemoraciones de héroes y batallas en el nacimiento de Bolivia”. En: Pablo Ortemberg (Dir.), El origen de las fiestas patrias: Hispanoamérica en la era de las independencias, Rosario: Prohistoria Ediciones, pp. 85-108.

Briones, Claudia (1994), "“Con la tradición de todas las generaciones pasadas gravitando sobre las mentes de los vivos': usos del pasado e invención de la tradición”. En: Runa, número 21, número 1, pp. 99-129. URL: http:// repositorio.filo.uba.ar/handle/filodigital/2233

(2007), “Teorías performativas de la identidad y performatividad de las teorías". En: Tabula rasa, número 6, pp. 55-83. URL: https://www.redalyc.org/ $\underline{\mathrm{html} / 396 / 39600603 /}$

Brito Figueroa, Federico (1988), "Venezuela colonial: las rebeliones de esclavos y la Revolución francesa”. En: Caravelle, número 54, pp. 263-289. URL: https:// www.jstor.org/stable/pdf/40851911.pdf?seq=1\#page_scan_tab_contents

Burbano de Lara, Felipe (2012), "Movimientos regionales y autonomías políticas en Bolivia y Ecuador". Tesis doctoral defendida en la Universidad de Salamanca. URL: https://gredos.usal.es/jspui/handle/10366/115574

Bustos Lozano, Guillermo (2010), "La conmemoración del primer Centenario de la independencia ecuatoriana: los sentidos divergentes de la memoria nacional”. En: Historia Mexicana, volumen LX, número 1, pp. 473-524. URL: http:// www.redalyc.org/articulo.oa? $\mathrm{id}=60021048011$ 
(2011), "La urdimbre de la Historia Patria. Escritura de la historia, rituales de la memoria y nacionalismo en Ecuador (1870-1950)" (Tesis doctoral). The University of Michigan, Ann Arbor.

Caicedo, Luis Javier (2010), “La construcción del bicentenario latinoamericano y los intentos de España por hispanizar la celebración de las independencias". En: Caravelle, número 94, pp. 157-184. URL: https://www.jstor.org/stable/pdf/ 40855064.pdf?seq=1\#page scan tab contents

Calderón Trejo, Eligia (2011), “Caracas en el Centenario de la Independencia: edificios y lugares para la memoria”. En: Portafolio, volumen 2, número 24, pp. 06-18.

Calzadilla, Pedro Enrique (1999), "El olor de la pólvora. Fiestas patrias, memoria y Nación en la Venezuela guzmancista 1870-1877”. En: Caravelle, número 73, pp.

$111-130 . \quad$ URL: $\quad \underline{\text { https://www.persee.fr/doc/ }}$ carav 1147-6753 1999 num $73 \quad 1 \quad 2856$

Cameron, Maxwell A. y Hershberg, Eric (2010), Latin America's left turns: Politics, policies, and trajectories of change, Boulder: Lynne Rienner Publishers.

Canelo, Paula (2013), “¿Qué hacer con las Fuerzas Armadas? Treinta años de ‘cuestión militar' en la Argentina". En: Observatorio Latinoamericano, número 12, pp. 136-148. URL: https://core.ac.uk/download/pdf/52479779.pdf

Cantamutto, Francisco (2017), "Fases del kirchnerismo: de la ruptura a la afirmación particularista”. En: Convergencia. Revista de Ciencias Sociales, volumen 24, número 74, pp. 63-89. URL: https://convergencia.uaemex.mx/article/view/4382

Carcelén Cornejo, Ximena et al (2006), "Ecuador en el Centenario de la lndependencia”. En: Apuntes. Revista de estudios sobre patrimonio cultural, volumen 19, número 2, pp. 236-255.

Cardozo Galué, Germán (2011), "Regiones históricas, independencia y construcción de la nación venezolana”. En: Académica, volumen 2, número 3, pp. 1-35. URL: https://dialnet.unirioja.es/servlet/articulo?codigo $=3748165$

Carrera Damas, Germán (2008), El culto a Bolívar, Caracas: Alfa.

Casas, Matías (2016), "Los militares argentinos y la consolidación de la identidad nacional desde la narrativa criollista". En: Revista Universitaria de Historia 
Militar, volumen 5, número 9, pp. 193-211. URL: https://dialnet.unirioja.es/ $\underline{\text { servlet/articulo?codigo }=6130645}$

Castañeda, Jorge (2006), “Latin America's Left Turn”. En: Foreign Affairs, volumen 85, número 3, pp. 28-43. URL: https://www.foreignaffairs.com/articles/southamerica/2006-05-01/latin-americas-left-turn

Cattaruzza, Alejandro (2003), "El revisionismo: itinerario de cuatro décadas". En: Alejandro Cattaruzza y Alejandro Eujanián, Políticas de la historia argentina 1860-1960, Buenos Aires: Alianza, pp. 143-185.

(2007), Los usos del pasado. La historia y la política argentina en discusión, 1910-1945, Buenos Aires: Sudamericana.

(2009), Historia de la Argentina. 1916-1955, Buenos Aires:

Siglo Veintiuno Editores.

(2011), "Las representaciones del pasado: historia y memoria".

En: Boletín del Instituto de Historia Argentina y Americana Dr. Emilio Ravignani, número 33, pp. 155-164. URL: http://www.scielo.org.ar/scielo.php? script $=$ sci arttext\&pid $=$ S0524-97672011000100023

Cattaruzza, Alejandro y Alejandro Eujanian (2002). "Del éxito popular a la canonización estatal del Martín Fierro. Tradiciones en pugna (1870-1940)”. En: Prismas. Revista de historia intelectual, número 6, pp. 97-120. URL: http:// www.saavedrafajardo.org/Archivos/Prismas/06/Prismas06-06.pdf

Cavarozzi, Marcelo (2011), “El peronismo kirchnerista... el peronismo de siempre”. En: Estudios: Centro d Estudios Avanzados, número 26, pp. 13-24. URL: https:// dialnet.unirioja.es/servlet/articulo?codigo $=5209696$

Ceceña, Ana Esther (2011), "Postneoliberalismo o cambio civilizatorio". En: Theotonio Dos Santos (ed.), América Latina y el Caribe: Escenarios posibles y políticas sociales, volumen 3, Montevideo: UNESCO/FLACSO, pp. 121-131. URL: https:// unesdoc.unesco.org/ark:/48223/pf0000210983

Chartier, Roger (1979), "La fête en question: Retour sur un colloque" y "Des fêtes de l'Ancien Régime à la fête révolutionnaire: problèmes de lecture”. En: Karin R. Giirttler and Monique Sarfati-Arnaud (Eds.), La Fête en question, Montreal: University of Montreal Press, pp. 1-4 y 35-36. 
(1994), “Cultura popular': retorno a un concepto historiográfico". En:

Manuscrits: Revista d'història moderna, número 12, pp. 43-62. URL: https:// www.raco.cat/index.php/Manuscrits/article/viewFile/23234/92462

(1996), Escribir las prácticas. Foucault, de Certau, Marin, Buenos Aires: Ediciones Manantial.

(2002), "La construcción estética de la realidad. Vagabundos y pícaros en la Edad Moderna". En: Tiempos Modernos: Revista Electrónica de Historia Moderna, volumen 3, número 7, pp. 1-15. URL: http:// www.tiemposmodernos.org/tm3/index.php/tm/article/view/20 (2007), La historia o la lectura del tiempo, Barcelona: Gedisa Editorial.

Chiaramonte, José Carlos (2001), "En torno a los orígenes del revisionismo histórico argentino". En: Ana Frega y Ariadna Islas (Eds), Nuevas miradas en torno al Artiguismo, Montevideo: Dpto. Publicaciones de la FHCE, pp. 29-61.

Chicharro Fernández, Elena (1987), "Notas sobre la evolución del pensamiento geográfico". En: Anales de geografía de la Universidad Complutense, volumen 7, pp. 43-52. URL: https://revistas.ucm.es/index.php/AGUC/article/view/ $\underline{\text { AGUC8787110043A }}$

Choque Condori, Germán (2004), Whipala guerrera, La Paz: Fondo Editorial de los Diputados.

Chust, Manuel (2007), “La independencia en Hispanoamérica. Reflexiones, revisiones y cuestiones antes de los Bicentenarios". En: Anuario de Historia Regional y de las Fronteras, número 12, pp. 385-414.

Citro, Silvia (2017), "Cuando 'los descendientes de los barcos' comenzaron a mutar: corporalidades y sonoridades multiculturales en el bicentenario argentino". En: AIBR: Revista de Antropología Iberoamericana, volumen 12, número 1, pp. 53-75. URL: https://dialnet.unirioja.es/servlet/articulo?codigo=5979191

Crain, Mary (2001), "La interpenetración de género y etnicidad: nuevas autorepresentaciones de la mujer indígena en el contexto urbano de Quito". En: Antología Género, Quito: FLACSO-Sede Ecuador/Junta de Andalucía, pp. 353-381. URL: http://www.ub.edu/SIMS/pdf/OrillasPolitica/OrillasPolitica-04.pdf 
Connerton, Paul (2012), How societies remember, Cambridge: Cambridge University Press.

Coronel, Valeria (2010), "El discurso civilizatorio y el lugar del trabajo en la nación poscolonial”. En: Valeria Coronel y Mercedes Prieto (Coords.), Celebraciones centenarias y negociaciones por la nación ecuatoriana, Quito: FLACSO, pp. $155-208$.

Coronel, Valeria y Prieto, Mercedes (2010), Celebraciones centenarias y negociaciones por la nación ecuatoriana, Quito: FLACSO.

DaMatta, Roberto (2002), Carnavales, malandros y héroes. Hacia una sociología del dilema brasileño, México: Fondo de Cultura Económica.

De Freitas, Leonor (2010), Centenario del 19 de abril (1810-1910), Caracas: Ministerio del Poder Popular para la Cultura.

De la Cadena, Marisol (1991), "Las mujeres son más lindas: etnicidad y género en una comunidad del Cuzco". En: Revista Andina, volumen 9, número 1, pp. 7-47.

Devoto, Fernando (1996), “De nuevo el acontecimiento: Roque Sáenz Peña, la reforma electoral y el momento político de 1912”. En: Boletín del Instituto del Instituto de Historia Argentina y Americana “Dr. Emilio Ravignani”, número 14, pp. 93-113. URL: http://repositoriouba.sisbi.uba.ar/gsdl/cgi-bin/library.cgi? $\underline{\mathrm{a}=\mathrm{d} \& \mathrm{c}=\text { bolravi\& } \mathrm{d}=14-4 \mathrm{htm}}$

(2014), "Conmemoraciones poliédricas: acerca del primer Centenario en la Argentina". En: Nora Pagano y Martha Rodríguez (Comp.), Conmemoraciones, patrimonio, y usos del pasado. La elaboración social de la experiencia histórica, Buenos Aires: Miño y Dávila, pp. 17-36.

Diamint, Rut (2008), "La historia sin fin: el control civil de los militares en Argentina". En: Nueva Sociedad, número 213, pp. 95-111. URL: https://nuso.org/media/ articles/downloads/3496_1.pdf

Di Meglio, Gabriel (2001), "Un nuevo actor para un nuevo escenario. La participación política de la plebe urbana de Buenos Aires en la década de la Revolución (1810-1820)". En: Boletín del Instituto de Historia Argentina y Americana "Dr. Emilio Ravignani”, número 24, pp. 7-43. URL: http://ravignanidigital.com.ar/ bol_ravig/n24/n24a01.pdf 
(2007), ¡Viva el bajo pueblo! La plebe urbana de Buenos Aires y la política entre la Revolución de Mayo y el rosismo, Buenos Aires: Prometeo.

Do Alto, Hervé (2011), “Un partido campesino en el poder: una mirada sociológica del MAS boliviano". En: Nueva Sociedad, número 234, pp. 95-111. URL: https:// nuso.org/media/articles/downloads/4. TC Do Alto 234.pdf

Doeswijk, Andreas (2010), "Revisionismo e historiografía en el Bicentenario de la Revolución de Mayo". En: Anuario del Centro de Estudios Históricos "Prof. Carlos SA Segreti”, volumen 10, número 1, pp. 15-34. URL: https:// dialnet.unirioja.es/servlet/articulo?codigo $=4082269$

Duvignaud, Jean (1973), Fêtes et civilisations: suivi de La fête aujourd'hui, París: Weber.

Ellner, Steve (2004), "Leftist goals and the debate over anti-neoliberal strategy in Latin America". En: Science \& Society, volumen 68, número1, pp. 59-81. URL: https:// www.jstor.org/stable/40404127?seq=1\#page scan tab contents

(2009), "La política exterior del gobierno de Chávez: la retórica chavista y los asuntos sustanciales”. En: Revista Venezolana de Economía y Ciencias Sociales, volumen 15, número 1, pp. 115-132. URL: http://www.redalyc.org/ articulo.oa?id=17721678006

Esteva-Grillet, Roldán (2010), "Las artes plásticas venezolanas en el Centenario de la independencia, 1910-1911”. En: Historia Mexicana, volumen 60, número 1, pp. 301-368. URL: http://www.redalyc.org/pdf/600/60021048007.pdf

Febvre, Lucien (2017) [1952], Combates por la historia, Barcelona: Ariel.

Fernández Bravo, Álvaro (2006), “Celebraciones centenarias: nacionalismo y cosmopolitismo en las conmemoraciones de la independencia (Buenos Aires 1910- Río de Janeiro 1922)”. En: Beatriz González Stephan y Jens Anderman (Eds.). Galerías del progreso: museos, exposiciones y cultura visual en América Latina, Rosario: Beatriz Viterbo.

French, John (2009), "Understanding the Politics of Latin America's Plural Lefts (Chavez/Lula): social democracy, populism and convergence on the path to a post-neoliberal world”. En: Third World Quarterly, volumen 30, número 2, pp. 349-370. URL: https://fds.duke.edu/db/attachment/1158 
Fradkin, Raúl (2003), “Centaures de la pampa. Le gaucho, entre l'histoire et le mythe”. En: Annales. Histoire, Sciences Sociales. Cambridge University Press, volumen 58, número 1, pp. 109-133. DOI: https://doi.org/10.1017/S0395264900002596

Gadamer, Hans-Georg (1991), La actualidad de lo bello: el arte como juego, símbolo y fiesta, Buenos Aires: Paidós.

(1993), El problema de la conciencia histórica, Madrid:

Editorial Tecnos.

Garavaglia, Juan Carlos (2000), “A la nación por la fiesta: las Fiestas Mayas en el origen de la nación en el Plata”. En: Boletín del Instituto de Historia Argentina y Americana “Dr. Emilio Ravignani”, número 22, pp.73-100. (2003), "Gauchos: identidad, identidades". En: América.

Cahiers du CRICCAL, volumen 30, número 1, pp. 143-151. URL: https:// www.persee.fr/doc/ameri 0982-9237 2003 num $30 \quad 1 \quad 1615$

García Canclini, Néstor (1987), "Ni folklórico ni masivo ¿Qué es lo popular”. En: Revista Diálogos de la comunicación, número 17, pp. 6-11. URL: https:// ilusionismosocial.org/pluginfile.php/530/mod_resource/content $/ 3 /$ garcia canclinil.pdf

(1988), “¿Reconstruir lo popular?”. En: Cuadernos del Instituto Nacional de Antropología y Pensamiento Latinoamericano, volumen 13, pp. 201-219. URL: https://revistas.inapl.gob.ar/index.php/cuadernos/article/view/ $\underline{450}$

García Larralde, Humberto (2008), El fascismo del siglo XXI. La amenaza totalitaria del proyecto politico de Hugo Chávez Frías, Caracas: Random House/ Debate.

García Linera, Álvaro (2008), “Empate catastrófico y punto de bifurcación”. En: Crítica y emancipación. Revista latinoamericana de Ciencias Sociales, volumen 1, número 1, pp. 23-33. URL: http://biblioteca.clacso.edu.ar/ar/libros/secret/CyE/ cye2S1a.pdf

Giarracca, Norma (2011), “El bicentenario: miradas sobre la argentina”. En: Norma Giarracca (comp.), Bicentenarios (otros), transiciones y resistencias, Buenos Aires: Una ventana ediciones, pp. 143-160. 
Goebel, Michael (2013), La Argentina partida. Nacionalismos y politicas de la historia, Buenos Aires: Prometeo.

Goetschel, Ana María (2006), Orígenes del feminismo en el Ecuador: Antología. Quito: FLACSO.

(2010), "Las paradojas del liberalismo y las mujeres: coyuntura 1907-1909”. En: Valeria Coronel y Mercedes Prieto (Coords.), Celebraciones centenarias y negociaciones por la nación ecuatoriana, Quito: FLACSO, pp. 209-240.

Gómez, Alejandro (2008), "La Revolución de Caracas desde abajo. Impensando la primera independencia de Venezuela desde la perspectiva de los Libres de Color, y de las pugnas político-bélicas que se dieran en torno a su acceso a la ciudadanía, 1793-1815”. En: Nuevo Mundo Mundos Nuevos. URL: https:// journals.openedition.org/nuevomundo/32982

Gómez, Fernando (2013), “Las Fiestas Mayas y la construcción de legitimidad en Buenos Aires (1811-1836): Del día de la regeneración política a un acto de orden y dignidad”. En: Prohistoria, número 19, pp. 73-93.

González, Malala (2015), “Configurar el relato: estética y montaje de imágenes performáticas en los festejos del bicentenario nacional”. En: Anales del Instituto de Arte Americano e Investigaciones Estéticas. Mario J. Buschiazzo, volumen 45, número 2, pp. 119-132. URL: http://www.iaa.fadu.uba.ar/ojs/index.php/anales/ $\underline{\operatorname{article} / \text { view/174 }}$

González Urrutia, Edmundo (2006), “Las dos etapas de la política exterior de Chávez”. En: Nueva Sociedad, número 205, pp. 159-171. URL: https://nuso.org/articulo/ las-dos-etapas-de-la-politica-exterior-de-chavez/

Gorelik, Adrián (1997), La grilla y el parque. Espacio público y cultura urbana en Buenos Aires, 1887-1936, Bernal: Universidad Nacional de Quilmes.

Grimson, Alejandro (2019), ¿Qué es el peronismo? De Perón a los Kirchner, el movimiento que no deja de conmover la política argentina, Buenos Aires: Siglo XXI.

Guédez, José Marcial Ramos (2011), "Participación de negros, mulatos y zambos en la Independencia de Venezuela, 1810-1823 (Nuevos Aportes)”. En: Academia 
Nacional de la Historia (Venezuela). Boletín de la Academia Nacional de la Historia, número 374, pp. 105-130.

Gustafson, Bret (2006), "Spectacles of autonomy and crisis: Or, what bulls and beauty queens have to do with regionalism in Eastern Bolivia". En: The Journal of Latin American and Caribbean Anthropology, volumen 11, número 2, pp. 351-379. URL: https://anthrosource.onlinelibrary.wiley.com/doi/abs/10.1525/jlca. $\underline{2006.11 .2 .351}$

Gutman, Margarita (2005), “Anticipando bicentenarios: imágenes centenarias del futuro". En: Margarita Gutman (Ed.), Construir Bicentenario: Argentina, Buenos Aires: Caras y Caretas, pp. 45-63.

Hall, Stuart (1984), "Notas sobre la deconstrucción de lo popular”. En: Ralph Samuel, Historia popular y teoría socialista, Barcelona: Crítica/Grijalbo, pp. 93-110.

URL: https://www.perio.unlp.edu.ar/catedras/system/files/ stuart hall_notas_version_definitiva.pdf

Halperín Donghi, Tulio (1970), El revisionismo histórico argentino, Buenos Aires: Siglo Veintiuno Editores. (2005a) [1972], Revolución y Guerra: Formación de una elite dirigente en la Argentina criolla, Buenos Aires: Siglo Veintiuno Editores. (2005b), El revisionismo histórico argentino como visión decadentista de la historia nacional, Buenos Aires: Siglo Veintiuno Editores.

Hernández, Virgilio y Buendía, Fernando (2011), “Ecuador: avances y desafíos de Alianza País". En: Nueva Sociedad, número 234, pp. 129-142. URL: https:// nuso.org/media/articles/downloads/3790_1.pdf.

Herrera, Gioconda (2010), "El congreso católico de mujeres en 1909 y la regeneración de la nación”. En: Valeria Coronel y Mercedes Prieto (Coords.), Celebraciones centenarias y negociaciones por la nación ecuatoriana, Quito: FLACSO, pp. 241-263.

Hobsbawm, Eric (1996), "La política de la identidad y la izquierda". En: Debate feminista, volumen 14, pp. 86-100.

Hobsbawm, Eric y Ranger, Terence (2002), La invención de la tradición, Barcelona: Crítica. 
Hora, Roy (2010), “La crisis del campo del otoño 2008”. En: Desarrollo Económico, volumen 50, número 197, pp. 81-111. URL: https://dialnet.unirioja.es/servlet/ $\underline{\text { articulo? codigo }=3713644}$

Huyssen, Andreas (2002), "En busca del futuro perdido". Cultura y memoria en tiempos de globalización, México: Fondo de Cultura Económica.

Ibarguren, Federico (1969), Orígenes del nacionalismo argentino 1927-1937, Buenos Aires: Celcius.

Irurozqui, Marta (1992), “Las élites bolivianas y la cuestión nacional, 1899-1920”. En: Tebeto: Anuario del Archivo Histórico Insular de Fuerteventura, número 5, pp. 201-216.

(2011), “Herencias escamoteadas. Una reflexión sobre los procesos de politización y de incorporación nacional de la población indígena, siglo XIX”. En: Culturas políticas en la región andina., pp. 223-245. URL: http:// publications.iai.spk-berlin.de/servlets/MCRFileNodeServlet/ Document derivate 00000561/BIA\%20145\%20Irurozqui.pdf

James, Daniel (1997), "Meatpackers, Peronists, and Collective Memory: A View from the South”. En: The American Historical Review, volumen 102, número 5, pp. $1404-1412$. URL: https://www.jstor.org/stable/2171070? $\underline{\text { seq }=1 \# \text { page scan tab_contents }}$

Jelin, Elizabeth (2002), Las conmemoraciones: las disputas en las fechas infelices, Madrid: Siglo XXI.

Krizmanics, Georg (2014), “Las políticas públicas de memoria y la integración latinoamericana: el Grupo Bicentenario". En: Anuario Latinoamericano-Ciencias Políticas y Relaciones Internacionales, volumen 1, pp. 25-44. URL: https:// journals.umcs.pl/al/article/view/230/228

Lalander, Rickard (2012), "Venezuela 2010-2011: Polarización y radicalización del proyecto socialista”. En: Revista de ciencia política, Santiago, volumen 32, número 1, pp. 293-313.

Lalander, Rickard y Ospina Peralta, Pablo (2012), "Movimiento indígena y Revolución Ciudadana en Ecuador”. En: Cuestiones Políticas, volumen 28, número 48, pp. $13-50$. 
Lander, Luis y López Maya, Margarita (1999), "Venezuela. La victoria de Chávez”. En: Nueva Sociedad, número 160, pp. 4-19. URL: https://nuso.org/articulo/venezuelala-victoria-de-chavez-el-polo-patriotico-en-las-elecciones-de-1998/

Langue, Frédérique (2013), “Usos del pasado y guerra de las memorias en la Venezuela de la 'Segunda Independencia'”. En: Polis, volumen 12, número 34. URL: https:// dialnet.unirioja.es/servlet/articulo?codigo $=5751661$

Lanzaro, Jorge (2007), 'La 'tercera ola' de las izquierdas latinoamericanas: entre el populismo y la social-democracia”. En: Encuentros Latinoamericanos, volumen 1, número 1, pp. 20-57. URL: http://www.cecies.org/imagenes/ edicion 116.pdf\#page $=20$

Lavabre, Marie-Claire (2006), "Sociología de la memoria y acontecimientos traumáticos”. En: Julio Aróstegui y François Godicheau (Eds.), Guerra civil: mito y memoria, Madrid: Marcial Pons.

Lesgart, Cecilia (2010), “Intelectuales y académicos produciendo el Bicentenario”. En:

Estudios, número 23-24, pp. 125-143. URL: https://revistas.unc.edu.ar/index.php/ $\underline{\text { restudios/article/view/424 }}$

Levene, Ricardo (1973) [1951], Las indias no eran colonias, Madrid: Espasa-Calpe.

Linares, Rosalba (2010), "La estrategia multipolar de la política exterior venezolana". En: Aldea Mundo, volumen 15, número 30, pp. 51-62.

Lomnitz, Claudio (2006), "Latin America's Rebellion: Will the New Left Set a New Agenda?’. En: Boston Review, a political and literary forum. URL: http:// bostonreview.net/claudio-lomnitz-latin-america-leftist-new-agenda

Londoño López, Jenny (2008), “Manuela Sáenz: 'mi patria es el continente de la América"”. En: Cuadernos Americanos, número 125, pp. 67-85. URL: http:// www.cialc.unam.mx/cuadamer/textos/ca125-67.pdf

López Maya, Margarita (2003), “Movilización, institucionalidad y legitimidad en Venezuela”. En: Revista Venezolana de Economía y Ciencias Sociales, volumen 9, número 1, pp. 211-226. URL: https://www.redalyc.org/html/177/17709111/ (2008), "Venezuela: Hugo Chávez y el bolivarianismo". En: Revista Venezolana de Economía y Ciencias Sociales, volumen 14, número 3, pp. 55-82. URL: http://www.redalyc.org/articulo.oa?id=17721699005 
López Maya, Margarita y Lander, Luis (2010), "Venezuela 2009: En medio de dificultades avanza el modelo socialista del Presidente Chávez”. En: Revista de ciencia política (Santiago), volumen 30, número 2, pp. 537-553. URL: https:// s c i e 1 o pid=S0718-090X2010000200018\&script $=$ sci arttext\&tlng $=$ en

López Trigal, Lorenzo (2011), “Las leyes del crecimiento espacial de los Estados” en el contexto del determinismo geográfico ratzeliano”. En: Geopolítica (s), volumen 2, número 1, pp. 157-163. URL: https://revistas.ucm.es/index.php/GEOP/article/ view/37903

Malamud, Carlos (2011), "Un balance de los bicentenarios latinoamericanos: de la euforia al ensimismamiento". En: Boletín Elcano, número 132. URL: http:// biblioteca.ribei.org/2198/1/DT-1-2011.pdf

Malosetti Costa, Laura (2010), “Arte e historia en los festejos del centenario de la Revolución de Mayo en Buenos Aires”. En: Historia Mexicana, volumen 60, número 1, México: El Colegio de México, pp. 439-471.

Marchesi, Aldo (2006), "Imaginación política del antiimperialismo: Intelectuales y política en el Cono Sur a fines de los sesenta". En: EIAL: Estudios Interdisciplinarios de América Latina y el Caribe, volumen 17, número 1, pp. 135-160. URL: https://dialnet.unirioja.es/servlet/articulo?codigo=4004299

Martínez, Françoise (2005), “Usos y desusos de las fiestas cívicas en el proceso boliviano de construcción nacional, siglo XIX.” En: Marta Irurozqui, La mirada esquiva. Reflexiones políticas sobre la interacción y la ciudadanía en los Andes (Bolivia, Ecuador y Perú), s. XIX, Madrid: CSIC, pp. 179-216. URL: https://

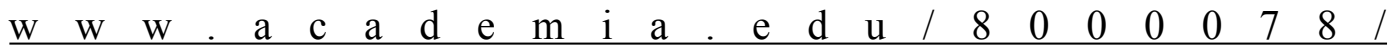
Usos y desusos de las fiestas c\% $\mathrm{C} 3 \%$ ADvicas en el proceso boliviano de construcción_nacional_siglo_XIX_in_Marta_Irurozqui ed. La_mirada_esquiva. Reflexiones_históricas_sobre la_interacción_del_Estado_y la_ciudadan $\% \mathrm{C} 3 \% \mathrm{~A}$ Da_en_los_Andes_Bolivia_Ecuador_y_Perú siglo_XIX_Madrid_CSIC_2005 (2013a), "Fiestas patrias y cívicas: sus avatares como instrumentos políticos de inclusión-exclusión (1825-1925).” En: Estudios Bolivianos, número 
19, pp. 118-141. URL: http://www.revistasbolivianas.org.bo/scielo.php? pid=S2078-03622013000200008\&script=sci_arttext

(2013b), "Monumentos de papel. Las obras conmemorativas publicadas en México y Bolivia en el primer centenario de su independencia”. En: Revista Boliviana de Investigación, número 10, pp. 47-90. URL: https:// w w w . a c c a d Monumentos_de_papel._Las_obras_conmemorativas_publicadas_en_México_y Bolivia_en_el_primer_centenario_de_su independencia_Revista_Boliviana_de Investigación-Bolivian research review vol.10 ag. 2013

Mayorga, Fernando (2006), "El gobierno de Evo Morales: entre nacionalismo e indigenismo". En: Nueva Sociedad, número 206, pp. 4-13. URL: http:// www.liderazgos-sxxi.com.ar/bibliografia/Mayorga-entre-nacionalismo-eindeginismo.pdf

Mc Evoy, Carmen (2006), Funerales Republicanos en América del Sur: tradición, ritual y nación, 1832-1896, Santiago de Chile: Ediciones Centro de Estudios Bicentenario, 2006.

Mendoza González, Jaime (2016) [1935] [1925], El Macizo Boliviano y El factor geográfico de la nacionalidad boliviana, La Paz: Biblioteca del Bicentenario de Bolivia. URL: https://www.bbb.gob.bo/publicaciones/macizo-boliviano-factorgeografico-la-nacionalidad-boliviana/

Molina, Fernando (2008), "Bolivia: la geografía de un conflicto". En: Nueva Sociedad, número 218, pp. 4-13. URL: https://nuso.org/media/articles/downloads/ 3567 1.pdf

Molinaro, Natalia (2013), "Los pueblos originarios en el Bicentenario argentino (2010): ¿Hacia un reconocimiento nacional?”. En: Amérique Latine Histoire et Mémoire. Les Cahiers ALHIM, número 24. URL: http://alhim.revues.org/4342 (2017), "Histoire, Mémoire et Identités dans l'Argentine du Bicentenaire (2010)". En: Conserveries mémorielles, número 20. URL: http:// cm.revues.org/2593

Montero, Ana Soledad (2011), ;Al final un día volvimos! Los usos de la memoria en los discursos kirchneristas (2003-2007), Buenos Aires: Prometeo. 
Morales Peña, Alicia (2009), "La historiografía venezolana de la independencia: de la provincia de Guayana al centro". En: Procesos Históricos, número 16, pp. 55-66. URL: https://www.redalyc.org/html/200/20013209005/

Moreira, Carlos y Barbosa, Sebastián (2010). "El kirchnerismo en Argentina: origen, apogeo y crisis, su construcción de poder y forma de gobernar". En: Sociedade e cultura, volumen 13, número 2, pp. 193-200. URL: https://www.redalyc.org/pdf/ 703/70316920005.pdf

Mosse, George L. (2007), La nacionalización de las masas. Simbolismo político y movimientos de masas en Alemania desde las guerras napoleónicas al Tercer Reich, Buenos Aires: Siglo XXI Editores.

Munilla, María Lía (2013), "Mayo en Buenos Aires: fiestas cívicas y discurso simbólico en el período revolucionario, 1810-1816”. En: Pablo Ortemberg (Dir.), El origen de las fiestas patrias: Hispanoamérica en la era de las independencias. Rosario: Prohistoria Ediciones, pp. 43-64.

Moreira, Carlos y Barbosa, Sebastián (2010), “El kirchnerismo en Argentina: origen, apogeo y crisis, su construcción de poder y forma de gobernar". En: Sociedade e Cultura, volumen 13, número 2, pp. 193-200. URL: https://www.redalyc.org/pdf/ 703/70316920005.pdf

Mouffe, Chantal (1985), "Hegemonía, política e ideología". En: Julio Labastida y Martín del Campo (Coords.), Hegemonías y alternativas políticas en América Latina. México: Siglo Veintiuno Editores, pp. 125-145.

(1999), El retorno de lo político. Comunidad, ciudadanía, pluralismo, democracia radical, Buenos Aires: Paidós.

(2006), “Democracia y pluralismo agónico". En: Revista de Derecho y Humanidades, número 12, p p . 17-27. URL: ht ptps:// derechoyhumanidades.uchile.cl/index.php/RDH/article/view/16195

Muñoz, María Antonia y Retamozo, Martín (2008), "Hegemonía y discurso en la Argentina contemporánea: Efectos políticos de los usos de 'pueblo' en la retórica de Néstor Kirchner”. En: Perfiles latinoamericanos, volumen 16, número 31, pp. $121-149$. URL: http://www.scielo.org.mx/scielo.php? pid $=$ S0188-76532008000100006\&script $=$ sci arttext 
Muratorio, Blanca (1994), "Nación, Identidad y Etnicidad: los indios ecuatorianos y sus imagineros a fines del siglo XIX”. En: Blanca Muratorio (Ed.), Imágenes e imagineros. Representaciones de los indígenas ecuatorianos, Quito: FLACSO, pp. 129-132.

Murilo de Carvalho, José (1997), La formación de las almas. El imaginario de la república en Brasil, Buenos Aires: Universidad Nacional de Quilmes.

Nora, Pierre (2008), Pierre Nora en Les lieux de mémoire, Montevideo: Ediciones Trilce, pp. 5-38.

O’Donnell, Mario (2014), Breve historia argentina. De la Conquista a los Kirchner, Aguilar, Buenos Aires: Aguilar.

Oliver, María Rosa (1995) [1965], Mundo, mi casa, Buenos Aires: Ediciones de la Flor.

Ortíz Lemos, Andrés (2014), “Sociedad civil y revolución ciudadana en Ecuador”. En: Revista mexicana de sociología, volumen 76, número 4, pp. 583-612. URL: http://

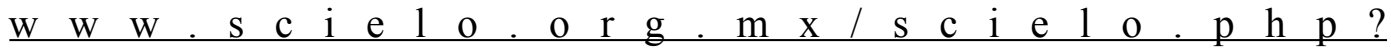
pid $=$ S0188-25032014000400003\&script $=$ sci_arttext\&tlng $=$ en

Ortemberg, Pablo (2013), El origen de las fiestas patrias: Hispanoamérica en la era de las independencias, Rosario: Prohistoria Ediciones.

(2014), Rituales del poder en Lima (1735-1828): de la monarquía a la república, Lima: Fondo Editorial, Pontificia Universidad Católica del Perú. (2015), "Geopolítica de los monumentos: los próceres en los centenarios de Argentina, Chile y Perú (1910-1924)”. En: Anuario de Estudios Americanos, volumen 72, número 1, pp. 321-350. URL: http:// estudiosamericanos.revistas.csic.es/index.php/estudiosamericanos/article/view/ $\underline{651}$

Ospina Peralta, Pablo (1996), "Imaginarios nacionalistas: historia y significados nacionales en Ecuador, siglos XIX y XX”. En: Procesos, número 9, pp. 111-124. (2011), “Corporativismo, Estado y revolución ciudadana. El Ecuador de Rafael Correa". En: Christian Büschges, Olaf Kaltmeier y Sebastian Thies (Eds.), Culturas políticas en la región andina, Madrid: Iberoamericana Vervuert, pp. 85-116. URL: http://publications.iai.spk-berlin.de/servlets/ 
MCRFileNodeServlet/Document derivate $00000555 /$ BIA \%20145\%200spina\%20Peralta.pdf

Ozouf, Mona (1976), La fête révolutionnaire 1789-1799, Paris: Gallimard.

Padilla, Cecilia y Ruiz del Ferrier, Cristina (2015), "Entrevista al Dr. Gerardo Aboy Carlés”. En: Revista Estado y Políticas Públicas, número 4, pp. 183-192. URL: http://revistaeypp.flacso.org.ar/files/revistas/1433485104_entrevista-1.pdf

Panizza, Francisco (2008), "Fisuras entre populismo y democracia en América Latina". En: Stockholm review of Latin American Studies, número 3, pp.: 81-93. URL: http://pdfhumanidades.com/sites/default/files/apuntes/ 135 panizza $\% 20$ fisuras $\% 20$ populismo $\% 20 \mathrm{y} \% 20$ democracia.pdf (2009), Contemporary Latin America. Development and Democracy Beyond the Washington Consensus, Londres: Zed Books.

Paramio, Ludolfo (2008), “El regreso del Estado: entre el populismo y la regulación”. Conferencia Plenaria en el XIII Congreso del CLAD, Buenos Aires. URL: https:// cladista.clad.org/handle/123456789/5004

Paredes Muñante, Jorge Guillermo Paredes (2015), “La conspiración contra Miranda del 31 de julio de 1812”. En: Diálogos Revista Electrónica, volumen 16, número 2, pp. 219-267. URL: https://revistas.ucr.ac.cr/index.php/dialogos/article/view/18094 Patrouilleau, María Mercedes (2010), "Discurso y narración en las dinámicas de constitución identitaria. La experiencia kirchnerista en Argentina”. En: CONfines de relaciones internacionales y ciencia política, volumen 6, número 11, pp. 37-58. U R L : ht t p://www.scie 1 o.org.mx/scie 1 o.php? pid $=$ S1870-35692010000100003\&script $=$ sci_arttext

Paz y Miño, Juan (2014), “Revolución y restauración: la Revolución de Quito (Ecuador) en el proceso de la independencia de América Latina". Congreso ADHILAC, Austria, Viena, 18 al 22 de septiembre de 2014. URL: http://the.pazymino.com/ JPyM_REVOLUCION_Y_RESTAURACION-Ponencia-ADHILACViena_Sep2014.pdf

Perochena, Camila (2013), "De oligarcas y revolucionarios: el Kirchnerismo argentino y el Panismo mexicano frente a sus centenarios". XIV Jornadas Interescuelas. 
Departamento de Historia, Facultad de Filosofía y Letras, Universidad Nacional de Cuyo, Mendoza. URL: http://cdsa.aacademica.org/000-010/638.pdf (2018), “Tiempo, historia y política. Una reflexión comparativa sobre las conmemoraciones bicentenarias en México y Argentina". En: História da Historiografia: International Journal of Theory and History of Historiography, número 27, pp. 142-172. URL: https://www.historiadahistoriografia.com.br/ revista/article/view/1280

Perrier Bruslé, Laetitia (2015), “La integración continental sudamericana, inscripción espacial y dispositivo discursivo. Apuntes desde Bolivia, el país de contactos". En: Journal of Latin American Geography, volumen 14, número 2, pp. 101-127.

Petkoff, Teodoro (2005), Dos izquierdas, Caracas: Alfadil Ediciones. URL: https:// muse.jhu.edu/article/586854

Pollak, Michael (2006), Memoria, olvido, silencio. La producción social de las identidades frente a situaciones límite, Buenos Aires: Ediciones Al Margen.

Portugal Mollinedo, Pedro (2010), “Condiciones para una verdadera descolonización”. En: Historia, coyuntura y descolonización. Katarismo e indianismo en el proceso político del MAS en Bolivia, La Paz: Fondo Editorial Pukara. URL: http:// www.rebelion.org/docs/123329.pdf

Prieto, Mercedes y Guaján, Verónica (2013), “Intelectuales indígenas en Ecuador: hablan y escriben mujeres kichwas". En: Nueva sociedad, número 245, pp. 136-148. URL: https://nuso.org/media/articles/downloads/3946 1.pdf

Quattrocchi-Woison, Diana (1995), Los males de la memoria. Historia y política en la Argentina, Buenos Aires: Emecé.

Quintero Montiel, Inés (2007), "Historiografía e independencia en Venezuela". En: Manuel Chust y José Antonio Serrano (Eds.), Debates sobre las independencias iberoamericanas, Madrid: Ahila-Iberoamericana, pp. 221-236. (2015), “'De celebración perpetua'. Fechas, héroes y fiestas para la Nación”. En: Anuario del Instituto de Historia Argentina, número 15. URL: https://dialnet.unirioja.es/servlet/articulo?codigo $=5379040$

(2018), Usos políticos de la historia en la Venezuela de Chávez y Maduro, Conferencia dictada en el Centro de Estudios Públicos. URL: https:// 
www.cepchile.cl/el-uso-politico-de-la-historia-en-la-venezuela-de-chavez-ymaduro/cep/2018-08-30/093644.html

Quispe, Felipe (2010), "Organizaciones y personajes históricos del movimiento Indianista Katarista". En: Historia, coyuntura y descolonización. Katarismo e indianismo en el proceso político del MAS en Bolivia, La Paz: Fondo Editorial Pukara. URL: http://www.rebelion.org/docs/123329.pdf

Rabotnikof, Nora (2009), "Política y tiempo: pensar la conmemoración". En: Sociohistórica, número 26, pp. 179-212. URL: https:// www.sociohistorica.fahce.unlp.edu.ar/article/view/n26a06

Ramírez Gallegos, Franklin (2006). "Mucho más que dos izquierdas". En: Nueva Sociedad, número 205. URL: https://nuso.org/articulo/mucho-mas-que-dosizquierdas/

(2010), "Post-neoliberalismo indócil. Agenda pública y relaciones socio-estatales en el Ecuador de la Revolución Ciudadana”. En: Temas y Debates, volumen 14, número 20, pp. 175-194. URL: https:// temasydebates.unr.edu.ar/index.php/tyd/article/view/54

Ramos Jiménez, Alfredo (2011), “La 'revolución' que no fue. Desgobierno y autoritarismo en la Venezuela de Chávez". En: Estudios Políticos, número 38, pp. 69-91. URL: http://www.scielo.org.co/pdf/espo/n38/n38a04.pdf

Retamozo, Martín (2013), "Discurso y lógicas políticas en clave K. Movimientos, populismo y hegemonía en Argentina". En: Javier Balsa (Comp.), Discurso, política y acumulación en el kirchnerismo, Quilmes: Centro Cultural de la Cooperación/Universidad Nacional de Quilmes, pp. 143-156. URL: https://

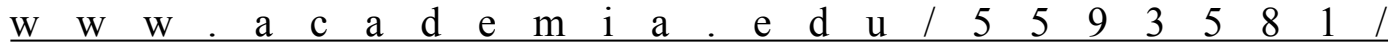
Discurso y lógicas pol\%C3\%ADticas en clave K. Movimientos populismo y hegemon $\% \mathrm{C} 3 \% \mathrm{ADa}$ en_Argentina

Richard, Bernard (2013), "Monumentos conmemorativos del Ecuador en el siglo XIX". En: Marcela Drien Fábregas, Teresa Espantoso Rodríguez y Carolina Vanegas Carrasco (Eds.), Tránsitos, apropiaciones y marginalidades del arte público en América Latina, Santiago de Chile: RIL editores/Universidad Adolfo Ibáñez. 
Ricoeur, Paul (1999), La lectura del tiempo pasado: memoria y olvido, Madrid: Arrecife.

(2013), La memoria, la historia, el olvido, Madrid: Editorial Trotta.

Robin, Régine (2012), La memoria saturada, Buenos Aires: Waldhuter Ediciones.

Roca, José Luis (1997), “El regionalismo como método de análisis histórico en la Bolivia del siglo XX”. En: Dora Cajías, Magdalena Cajías, Carmen Johnson e Iris Villegas (Eds.), Visiones de Fin de Siglo. Bolivia y América Latina en el siglo XX, Lima: Institut français d'études andines/ Plural editores. URL: https:// books.openedition.org/ifea/7240

Rodríguez, Jaime (2004), "De la fidelidad a la revolución: el proceso de la independencia de la antigua provincia de Guayaquil, 1809-1820”. En: Procesos. Revista ecuatoriana de historia, volumen 1, número 21, pp. 35-88. URL: http:// revistaprocesos.ec/ojs/index.php/ojs/article/view/237 (2006), La revolución política durante la época de la independencia. El reino de Quito, 1808-1822, Quito: Editorial Ecuador.

Rodriguez, Martha (2014), "La conmemoración del bicentenario argentino: intelectuales, Estado y producción editorial". En: Nora Pagano y Martha Rodriguez (Comps.), Conmemoraciones, patrimonio y usos del pasado. La elaboración social de la experiencia histórica, Buenos Aires: Miño y Dávila, pp. $57-74$.

Rojas, Reinaldo (1993), "Rebeliones de esclavos negros en Venezuela antes y después de 1789”. En: Revista Principia, número 12, pp. 27-36. URL: https://ebuah.uah.es/ $\mathrm{dspace} / \mathrm{b} \mathrm{its} \mathrm{tr}$ e a m/hand $1 \mathrm{e} / 100017 / 5837 /$ Rebeliones $\% 20 \mathrm{de} \% 20$ Esclavos $\% 20$ Negros $\% 20$ en $\% 20$ Venezuela $\% 20$ Antes $\% 20 \mathrm{y}$ \%20Después\%20de\%201789.pdf?sequence $=1$

(2005), "El retorno de los héroes: el discurso político de Hugo Chávez y el proceso constituyente en Venezuela de 1999”. En: MINIUS, número 13, pp. 309-322.

Romero Jiménez, Juan Eduardo (2007), “Las elecciones presidenciales en Venezuela 2006. Perspectivas Políticas e Implicaciones para América Latina y para la 
situación socio-política de Venezuela”. En: Nuevo Mundo Mundos Nuevos. URL: https://journals.openedition.org/nuevomundo/3900

Rosemberg, Julia y Farías, Matías (2011), Conversaciones. Bicentenario: Historia y Política en los años kirchneristas, Buenos Aires: Casa Nova Editores.

Rossi, Paolo (2003), El pasado, la memoria, el olvido: ocho ensayos de historia de las ideas, Buenos Aires: Nueva Visión.

Rousso, Henry (2007), "La trayectoria de un historiador del tiempo presente, 1975-2000”. En: Anne Marie Pérotin-Dumon (Dir.), Historizar el pasado vivo en América Latina. URL: http://www.historizarelpasadovivo.cl/downloads/ rousso.pdf

Rüsen, Jörn (2002), Western Historical Thinking: an intercultural debate. Vol. 1, New York: Berghahn Books.

Rufer, Mario (2012), “De las carrozas a los caminantes: Nación, estampa y alteridad en el bicentenario argentino". En: Mario Rufer (Coord.), Nación y diferencia. Procesos de identificación y formaciones de otredad en contextos poscoloniales, México: Editorial Itaca.

Ruiz, Apen (2001), "La india bonita: nación, raza y género en el México revolucionario". En: Debate feminista, volumen 24, pp. 142-162. URL: https:// www.jstor.org/stable/42625405?seq=1\#page_scan_tab_contents

Saavedra, José Luis (2010), “El devenir del proceso katarista e indianista”. En: Historia, coyuntura y descolonización. Katarismo e indianismo en el proceso político del MAS en Bolivia, La Paz: Fondo Editorial Pukara. URL: http://www.rebelion.org/ docs/123329.pdf

Sader, Emir (2008), Posneoliberalismo en América Latina, Buenos Aires: CLACSOCTA.

Salvador González, José María (2006), “Construcción de un imaginario nacionalista mediante la estatuaria pública en la Venezuela de Antonio Guzmán Blanco (1870-1888)". V Jornadas de Historia Contemporánea: “Teoría e historia de los nacionalismos", Universidad de Oviedo: Oviedo. 
Salvatore, Ricardo (1996), Fiestas federales: representaciones de la República en el Buenos Aires rosista. En: Entrepasados, volumen 11, pp. 45-68. URL: http:// www.historiapolitica.com/datos/biblioteca/rituales_salvatore.pdf

Sarlo, Beatriz (1988), "Lo popular en la historia de la cultura". En: Cuadernos del Instituto Nacional de Antropología y Pensamiento Latinoamericano, volumen 13, pp. 221-232. URL: https://revistas.inapl.gob.ar/index.php/cuadernos/article/view/ $\underline{451}$

(2007a), Tiempo pasado. Cultura de la memoria y giro subjetivo. Una discusión, Buenos Aires: Siglo XXI Editores.

(2007b), Borges, un escritor en las orillas, Buenos Aires: Siglo XXI Editores.

Schechner, Richard (2011), "Restauración de la conducta”. En: Diana Taylor y Marcela A. Fuentes (Eds.), Estudios avanzados de performance, México DF: Fondo de Cultura Económica.

Shumway, Jeffrey (2010), “'A veces saber olvidar es también tener memoria’: La repatriación de Juan Manuel de Rosas, el menemismo, y las heridas de la memoria Argentina". En: Osvaldo Barreneche y Andrés Bisso (Comps.), Ayer, hoy y mañana son contemporáneos. Tradiciones, leyes y proyectos en América Latina, La Plata: Edulp, pp.: 93-132.

Sidicaro, Ricardo (2011), "El partido peronista y los gobiernos kirchneristas". En: Nueva Sociedad, número 234, pp. 74-94. URL: http://www.liderazgossxxi.com.ar/sitio-wordpress/wp-content/uploads/2013/07/Sidicaro.pdf

Sotelo, María Belén (2011), "Yo estuve ahí. Reflexiones sobre los significados de la conmemoración de los significados del Bicentenario en Argentina”. VI Jornada de Jóvenes Investigadores, Instituto Gino Germani, Facultad de Ciencias Sociales, Universidad de Buenos Aires, Buenos Aires.

Stefanoni, Pablo (2004), “Articulando lo político y lo social: Algunas reflexiones sobre el MAS-IPSP”. En: Temas sociales, número 25, pp. 15-43. URL: http:// www.scielo.org.bo/pdf/rts/n25/n25a03.pdf 
(2006), "El nacionalismo indígena en el poder". En: OSAL,

Observatorio Social de América Latina, año VII, número 19, pp. 37-44. URL: http://www.liderazgos-sxxi.com.ar/bibliografia/stefanoni.pdf

(2010), “Qué hacer con los indios..." Y otros traumas irresueltos de la colonialidad, La Paz: Plural editores.

(2011), "Bolivia hoy: rupturas, inercias y desafíos". En: Bolivian Studies Journal, volumen 18, pp. 23-48.

(2015a), Los inconformistas del centenario: intelectuales, socialismo y nación en una Bolivia en crisis (1925-1939), La Paz: Plural Editores.

(2015b), “La 'era Evo Morales' y el retorno del antiliberalismo en el siglo XXI boliviano (2000-2013)”, En: Historia de Bolivia, Moscú: Nauka.

Stortini, Julio (2007), "Rosas a consideración: historia y memoria durante el menemismo”. XI Jornadas Interescuelas y Departamentos de Historia, Facultad de Filosofía y Letras, Universidad de Tucumán, San Miguel de Tucumán. URL: http://cdsa.aacademica.org/000-108/191.pdf

(2015), "Fervores patrióticos: Monumentos y conmemoraciones revisionistas en la historia reciente”. En: A. Eujanian, R. Pasolini, y M. E. Spinelli (Coords.), Episodios de la cultura histórica argentina: Celebraciones, imágenes y representaciones del pasado, siglo XIX y XX, Buenos Aires: Biblos, pp. 85-104.

Suriano, Juan (2010), "Los festejos del primer Centenario de la Revolución de Mayo y la exclusión del movimiento obrero". En: Revista de Trabajo-Nueva Época, número 8, pp. 19-28. URL: http://historiapolitica.com/datos/biblioteca/suriano.pdf (2015), "El Bicentenario de la Revolución de Mayo y los discursos públicos sobre la historia”. En: TAREA, número 2, pp. 154-172.

Svampa, Maristella (2011), “Argentina, una década después: Del 'que se vayan todos’a la exacerbación de lo nacional-popular”. En: Nueva sociedad, número 235, pp. 17-34. URL: https://www.cetri.be/IMG/pdf/3794_1.pdf

Svampa, Maristella, Stefanoni, Pablo y Fornillo, Bruno (2010), Debatir Bolivia: perspectivas de un proyecto de descolonización, Buenos Aires: Taurus.

Taylor, Diana (2015), Performance, Buenos Aires: Asunto Impreso Ediciones. 
Thomasz, Ana Gretel, María Florencia Girola y Marcela Alejandra País Andrade (2011), "Buenos Aires en el Bicentenario (1810-2010): consideraciones acerca de la ciudad y lo urbano”. En: Revista Pilquen, número 14, pp. 1-11. URL: http:// W $\mathrm{W}$ W $\underline{\text { script }=\text { sci abstract\&pid }=\text { S1851-31232011000100017 }}$

Thwaites Rey, Mabel (2010), “Después de la globalización neoliberal ¿Qué Estado en América Latina". En: OSAL, número 27, Buenos Aires: CLACSO. URL: http:// biblioteca.clacso.edu.ar/clacso/osal/20140310025634/05Thwaites.pdf

Todorov, Tzvetan (2000), Los abusos de la memoria, Buenos Aires: Paidós.

Tórrez, Yuri y Arce, Claudia (2014), “El Estado Plurinacional y su simbología”. En: T’inkazos, número 35, pp. 79-91.

Turner, Victor (1982), From Ritual to Theatre: the human seriousness of play, New York: Performing Arts Journal Publications.

Journal Publications.

Tutino, John (1997), "La negociación de los Estados nacionales, el debate de Las culturas nacionales: 'Peasant and nation' en la América Latina del siglo XIX”. En: Historia mexicana, volumen 46, número 3, pp. 531-562. URL: https:// historiamexicana.colmex.mx/index.php/RHM/article/view/2366

Vilalta, María José (2012), "Historia de las mujeres y memoria histórica: Manuela Sáenz interpela a Simón Bolívar (1822-1830)”. En: European Review of Latin American and Caribbean Studies/Revista Europea de Estudios Latinoamericanos y del Caribe, número 93, pp. 61-78. URL: https://www.jstor.org/stable/23294471? $\underline{\text { seq }=1 \# \text { page scan tab_contents }}$

Vilas, Carlos (2006), "The Left in South America and the Resurgence of NationalPopular Regimes”. En: Eric Hershberg y Fred Rosen (Eds.), Latin America after Neo Liberalism: Turning the Tide in the 21st Century, Nueva York: The New Press/NACLA.

Virno, Paolo (2003), El recuerdo del presente. Ensayo sobre el tiempo histórico, Buenos Aires: Paidós. 
Vovelle, Michel (1976), Les métamorphoses de la fête en Provence 1750-1820, Paris: Aubier-Flammarion. (1985), Ideologías y mentalidades, Barcelona: Ariel.

Williams, Raymond (2009), Marxismo y literatura, Buenos Aires: Las cuarenta.

Wittum, Caleb (2015), “Making La Ciudad Blanca: Race, Region, and Reconstruction in Nation Building Bolivia" (Tesis de maestría). University of North Carolina Chapel Hill. URL: https://scholarcommons.sc.edu/cgi/viewcontent.cgi? article $=4126 \&$ context $=$ etd

Zalles Cueto, Alberto Augusto (2006), “Una pieza más en el rompecabezas boliviano: El proyecto autonomista de Santa Cruz". En: Nueva Sociedad, número 1, pp. 20-32. URL: https://nuso.org/articulo/una-pieza-mas-en-el-rompecabezaboliviano/ 